\author{
UNIVERSIDADE DE SÃO PAULO \\ FACULDADE DE FILOSOFIA, LETRAS E CIÊNCIAS HUMANAS \\ DEPARTAMENTO DE GEOGRAFIA \\ PROGRAMA DE PÓS-GRADUAÇÃO EM GEOGRAFIA HUMANA
}

\author{
DIRCE SIZUKO SOKEN
}

Brasil e Bolívia: a mulher como força de trabalho e o processo de acumulação capitalista na dinâmica do circuito comercial transfronteiriço

VERSÃO CORRIGIDA

SÃO PAULO

2016 
DIRCE SIZUKO SOKEN

\title{
Brasil e Bolívia: a mulher como força de trabalho e o processo de acumulação capitalista na dinâmica do circuito comercial transfronteiriço
}

\author{
VERSÃO CORRIGIDA
}

De acordo:

Professora Dra Rosa Ester Rossini

Tese apresentada ao Programa de PósGraduação em Geografia Humana - FFLCH, da Universidade de São Paulo, como requisito parcial para obtenção do título de Doutora em Geografia.

Orientadora: Prof. Dra ${ }^{\mathrm{a}}$. Rosa Ester Rossini 
À Helena e ao Kozo, amor incondicional 


\section{Agradecimentos}

O caminho da pesquisa da tese de doutorado foi construído por pessoas dispostas a compreender as relações entre o Gênero e a Fronteira, primeiramente a minha orientadora Prof. Dr ${ }^{\mathrm{a}}$ Rosa Ester Rossini por insistir com o tema da tese e me conceder tempo para pensar a pesquisa. Agradeço pelo convívio e por propiciar ambiente acadêmico saudável e solidário a todas (os) as (os) orientandas (os). Sobretudo, sou grata por dialogar com o Gênero a partir da Geografia, resultado da sua tese de livre docência que referenciou a metodologia desta pesquisa.

Ao Prof. Dr ${ }^{\mathrm{o}}$ Tito Carlos Machado de Oliveira, pioneiro nas pesquisas sobre a fronteira no estado de Mato Grosso do Sul, agradeço imensamente pela formação acadêmica a qual me possibilitou construir caminho sólido e com capacidade de enfrentar novos desafios, como por exemplo, estudar as cidades-gêmeas de fronteira.

Sou grata as pessoas que contribuíram para minha estadia no Laboplan (Laboratório de Geografia Política e Planejamento Territorial) e foram fundamentais para o sucesso desta pesquisa, a Elisa de Freitas agradeço as sugestões e revisão criteriosa dos capítulos; ao Pedro Mezgravis pela contribuição teórica do primeiro capítulo da tese; ao Mateus Sampaio pela cordialidade e disposição de discutir os dados da pesquisa; ao Danton Bini pela iniciativa de rediscutir a temática gênero; ao José Fonseca, Lúcia Lirbório, Aline Santos e André Luís Gomes pelas contribuições nos seminários de pesquisa.

Tenho imensa gratidão à pessoa Ana Pereira, aos professores do Departamento de Geografia e aos colegas do laboratório responsáveis pelo excelente ambiente de encontros e debates que contribuem para o desenvolvimento das pesquisas do Programa de PósGraduação em Geografia Humana.

A professora Dra Rita de Cássia Ariza da Cruz gostaria de agradecer as considerações realizadas ao projeto de pesquisa durante o curso da disciplina Teoria e Métodos de Geografia, muito ajudou na operacionalidade da presente tese.

Em nome da professora Nosimar Ferreira dos Santos Rosa, quem viabilizou meu pedido de afastamento das atividades docentes do Câmpus do Pantanal da Universidade Federal de Mato Grosso do Sul para me dedicar exclusivamente ao programa do 
doutorado, agradeço aos professores dos cursos de graduação em Administração, Contábeis e Direito e aos técnicos administrativos, sem o afastamento não seria possível tal concretude.

A equipe de docentes e técnicos da Pró-reitoria de Pós-Graduação (PROPP) e da Pró-reitoria de Graduação (PREG) da UFMS pelo apoio institucional e acompanhamento dos relatórios e publicações da pesquisa da tese.

As todas as pessoas entrevistadas, em especial as mulheres do comércio das cidades de Corumbá, de Puerto Quijarro e de Puerto Suarez que foram fundamentais para a realização da pesquisa de campo.

Sou eternamente grata a família do meu irmão Armando, a minha cunhada Anita e aos meus sobrinhos Lenita, Nestor e Rodolfo pelo apoio incondicional aos meus estudos, pelo conforto de um lar e, principalmente, por compartilhar as experiências de vida do cotidiano paulista. Agradeço pelo convívio familiar que vou me lembrar com muita alegria.

Ao meu irmão Evaldo e minha sobrinha Heleninha pela companhia durante as pesquisas nas cidades bolivianas. A minha sobrinha Nathália pelo apoio e carinho de sempre. As minhas irmãs Eneida, Nilza e Kátia pelos cuidados maternais e ao Milton, Ernesto, Jairton e Walter pela satisfação de tê-los como irmãos. Pela hospitalidade familiar de Adriana, Adélia e Alice. A Magda Maciel (irmã de coração) e Odenir que contribuíram para o desfecho da tese. A todos os meus familiares e amigos que me ajudaram nessa jornada acadêmica.

Enfim, meus sinceros agradecimentos a todas (os) que gentilmente compartilharam seu conhecimento e ajudaram a construir o caminho da minha tese de doutorado. 


\section{RESUMO}

Esta pesquisa da tese de doutorado tratou de compreender como a mulher brasileira e boliviana contribui para a (re)produção do espaço transfronteiriço das cidades-gêmeas de Corumbá, no Brasil, e das cidades de Puerto Quijarro e Puerto Suarez, na Bolívia. A abordagem geográfica sobre o trabalho produtivo e reprodutivo da mulher teve como pressuposto a produção do espaço, uma vez que a divisão social do trabalho implica em divisão sexual do trabalho, ou seja, o trabalho feminino é uma questão de análise do espaço. Observou-se que a pesquisa de Gênero na Geografia tem como propósito entender a organização desse espaço transfronteiriço a partir do uso da força de trabalho feminino no comércio, onde as mulheres organizam a atividade concomitante a reprodução social. O princípio norteador do método da pesquisa foi a formação sócioeconômica das cidadesgêmeas entre Brasil e Bolívia e revelou os vários períodos de ocupação desse espaço fronteiriço. Duas frentes de ocupação se destacaram no estudo, pois potencializaram as relações transfronteiriças ao longo das décadas de 1990 e 2000: a circulação de produtos industrializados provenientes das principais fronteiras, foram elas: a brasileira, a chilena, a peruana e a argentina; e a expansão do comércio popular, especialmente de confecção, para as fronteiras bolivianas com uso da força de trabalho feminina. Sobretudo, no que se refere à base teórica metodológica sobre o trabalho feminino na área de fronteira, a investigação orientou-se pelas análises socioeconômica, espacial e pelo conceito da divisão sexual do trabalho. A pesquisa evidenciou a importância das famílias, empresas e agentes governamentais consolidados nos territórios de fronteira, pois funcionam como organismos sociais do Estado ratzeliano. Adotou-se a pesquisa qualitativa por meio de observações, imagens fotográficas, reportagens e noticiários da imprensa local, bem como, de entrevistas semi-estruturadas e informais para a coleta de dados nas cidadesgêmeas de fronteira. Em termos gerais, constatou-se que as mulheres que trabalham no comércio do circuito inferior das cidades-gêmeas entre Brasil e Bolívia foram as responsáveis pela pulverização das relações transfronteiriças, mediante as formas de organização dos negócios e do trabalho e, principalmente, pelo estreitamento dos laços familiares. Portanto, revelou-se que a atividade comercial operacionalizada pela mulher faz dela importante articuladora dos arranjos territoriais da fronteira.

Palavras-chaves: cidades-gêmeas; espaço transfronteiriço; divisão sexual do trabalho; Brasil e Bolívia. 


\begin{abstract}
This doctoral dissertation deals with the comprehension of how the Brazilian and Bolivian woman contributes to the reproduction of the transboundary space from Corumba's twin cities, in Brazil, and in Bolivian cities Puerto Quijaro and Puerto Suarez. The geographic approach about the productive and reproductive work of woman supposes the production of space, once that the social division of work implies in sexual division of work, so the female labour is a matter of analysis of space. The gender research in Geography has as purpose to understand the spatial organization of this cross-border space, from the use of the women's workforce in the trade, where the women organize the activity concomitantly with the social reproduction. The research method had as mainspring principle the socio-spatial of the twin-cities border between Brazil and Bolivia and revealed the several periods of occupation of this border space. Two occupancy fronts highlighted in the study, which potentiate the cross-border relationship, over the 1990s and 2000s: the circulation of industrialized products from principal borders, as the Brazilian, Chilean, Peruvian, Argentinian; and the popular expansion trade, especially of clothing manufacture, for the Bolivian borders with the use of women's work. Especially as regards to the methodologic theoretical base about the women's work in the border area, the investigation was oriented by the socioeconomic analysis, spatial and by the concept of sexual division of work. The research evidenced the importance of the families, business and governmental agents consolidated in the border territory, since they work as social organisms of ratzelian State. The qualitative research were adopted by means of observations, photograph images, news and local press news, as well the semi structured and informal interviews for the data collection in the twin-cities border. Generally speaking, it was found that the women working in the trade of the low circuits from twin-cities between Brazil and Bolivia, were the responsible for the spraying of the cross-borders relationships, by means of organization modes from the business, work and manly by the narrowing of the family bond. Therefore, it was revealed that the business activity operationalized by woman makes her an important articulator of the border territorial arrangements.
\end{abstract}

Keywords: twin cities; cross-border space; sexual division of work; Brazil and Bolivia. 


\section{Lista de Tabelas}

TABELA 1 - População total da fronteira linha (Brasil e Bolívia), referente ao final do período Imperial e início do Republicano - 1845 a 1900.

TABELA 2 - População urbana da faixa de fronteira (Brasil e Bolívia), referente ao período da "vivificação" - 1950 a 1980.

TABELA 3 - População urbana da faixa de fronteira (Brasil e Bolívia), referente ao período do comércio popular na fronteira" - 1991 a 2012

TABELA 4 - Índices de Commodities do Banco Central (IC-Br) e Commodity

Research Bureau (CRB), de dezembro de 2005 a março de 2013, em número índice (base: dezembro de 2005=100)

TABELA 5 - Capacitação de jovens para trabalhar no setor de têxtil e confecção da Bolívia, dados de 2013.

TABELA 6 - Formas de subcontratação de unidades familiares por unidade empresarial dos setores têxtil, vestuário e calçados, cidades de La Paz e El Alto, Bolívia, ano de referência 2002.

TABELA 7 - Taxa de atividade feminina por faixa etária, nos anos de 1970, 1990, 2002 e 2010 - Brasil

TABELA 8 - Faixa etária de 0 a 14 anos e acima de 60 anos, segundo Censo de 2010 (Brasil) e Censo 2012 (Bolívia), por sexo, em porcentagem da população total.

TABELA 9 - População ocupada por setores de atividade (número de pessoas e porcentagem) distribuída por sexo, conforme Censos demográfico dos anos de 2000 e 2010, Brasil.

TABELA 10 - Rendimento médio no trabalho principal da população ocupada de 16 anos ou mais de idade por posição na ocupação (em moeda $\mathrm{R} \$$ ), por sexo, para os anos de 2000 e 2010, Brasil.

TABELA 11 - Rendimento médio no trabalho principal da população ocupada por tipo de emprego (em moeda Bs\$), por sexo, para os anos de 2001 e 2013, Bolívia.

TABELA 12 - Total de mulheres distribuída em Corumbá, Puerto Quijarro e Puerto Suarez, por setor pesquisado. Período de abrangência corresponde a 15 a 23 de março de 2013.

TABELA 13 - Total de mulheres segundo faixa de salário-mínimo distribuído por setor pesquisado. Período de abrangência corresponde a 15 a 23 de março de 2013.

TABELA 14 - Total de mulheres segundo faixa de salário-mínimo distribuída em Corumbá, Puerto Quijarro e Puerto Suarez, período de abrangência corresponde a 15 a

23 de março de 2013.

TABELA 15 - Total de mulheres segundo jornada de trabalho por condição de trabalho distribuída em Corumbá, Puerto Quijarro e Puerto Suarez, período de abrangência corresponde a 15 a 23 de março de 2013.

TABELA 16 - Total de mulheres segundo nível de escolaridade distribuído por lugar, período de abrangência corresponde a 15 a 23 de março de 2013.

TABELA 17 - Total de mulheres segundo motivos de trabalhar na área de fronteira distribuída em Corumbá, Puerto Quijarro e Puerto Suarez, período de abrangência corresponde a 15 a 23 de março de 2013. 
TABELA 18 - Comparativo do setor referente a diferença da remuneração média segundo sexo (valores em R \$), distribuído conforme a participação do pessoal por setor em porcentagem, ano de 2013. 


\section{Lista de Gráficos}

GRÁFICO 1 - Taxa de câmbio em série do Brasil e da Bolívia, segundo moeda nacional por dólar estadunidense - 2001 a 2014.

GRÁFICO 2 - Salário mínimo nominal da Bolívia, segundo os anos de 2001 a 2015, em moeda local.

GRÁFICO 3 - Salário mínimo nominal do Brasil, segundo os anos de 2001 a 2015, em

moeda local.

GRÁFICO 4 - Regime de meta de inflação no Brasil: inflação (IPCA-IBGE), centro e "teto" da meta, 1999 a 2013*, em \% ao ano

GRÁFICO 5 - Saldos da Balança Comercial da Bolívia do setor Têxtil e de Confecção, segundo valor em dólar, para os anos de 2000 a 2013.

GRÁFICO 6 - Taxa de crescimento do PIB a preços constantes, segundo atividade econômica, referente aos anos de 2000 a 2013.

GRÁFICO 7 - Balança Comercial da Bolívia com os principais países, segundo o setor têxtil, no ano de 2013, a preços em moeda americana.

GRÁFICO 8 - Balança Comercial da Bolívia com os principais países, segundo o setor confecção, no ano de 2013, a preços em moeda americana.

GRÁFICO 9 - Balança Comercial da Bolívia com os principais parceiros comerciais, segundo o setor confecção, referente aos anos de 2000 a 2013, a preços em moeda americana.

GRÁFICO 10 - Balança Comercial da Bolívia com os principais parceiros comerciais, segundo o setor têxtil, referente aos anos de 2000 a 2013, a preços em moeda americana.

GRÁFICO 11 - Participação do setor textil no total de importação de manufaturados da Bolívia, segundo principais países, referente aos anos de 2000 a 2013

GRÁFICO 12 - Participação do setor de confecção no total de importação de manufaturados da Bolívia, segundo principais países, referente aos anos de 2000 a 2013

GRÁFICO 13 - Fatores que impedem a utilização plena da capacidade produtiva da indústria boliviana, referente aos anos de 2000 a 2008

GRÁFICO 14 - Taxa de consumo de energia elétrica do setor têxtil e confecção, segundo Índice da Indústria boliviana (1990=100), referente aos anos de 2000 a 2012

GRÁFICO 15 - Taxa de utilização da capacidade produtiva instalada do setor têxtil e confecção e da indústria boliviana, nos anos de 2000 a 2012.

GRÁFICO 16 - Distribuição da população ocupada da Bolívia, segundo a principal ocupação, por sexo, referente ao ano de 2011.

GRÁFICO 17 - Remuneração da população feminina ocupada nas principais atividades, segundo o tipo de emprego na Bolívia, referente aos anos de 2001 a 2009. 
GRÁFICO 18 - Remuneração da população masculina ocupada nas principais atividades, segundo o tipo de emprego na Bolívia, referente aos anos de 2001 a 2009.

GRÁFICO 19 - Taxa de atividade segundo sexo e por faixa etária, conforme Censos de 2000 e 2010 - Brasil

GRÁFICO 20 -Taxa de atividade feminina por categoria ocupacional nos anos de 1970, 1976, 1980, 1990, 1993, 1998 - Brasil

GRÁFICO 21- Distribuição da população ocupada feminina do Brasil, por posição na ocupação (\%), segundo os Censos de 2000 e 2010.

GRÁFICO 22 - Distribuição da população ocupada feminina da Bolívia, segundo tipo de emprego (\%), referente aos anos de 2000 e 2011.

GRÁFICO 23 - Taxa de atividade feminina segundo categoria ocupacional da Bolívia, referente aos anos de 2000 e 2013

GRÁFICO 24 - Rendimento médio no trabalho principal da população ocupada de 16 anos ou mais de idade, por posição na ocupação (em Salário Mínimo), por sexo, para o ano de 2010, Brasil.

GRÁFICO 25 - Rendimento médio no trabalho principal da população ocupada por tipo de emprego (em moeda Bs\$), por sexo, para o ano de 2013, Bolívia.

GRÁFICO 26 - Taxa feminina de rendimento mensal por jornada de trabalho semanal, segundo faixa de salário mínimo, nos anos de 1993 e 2002 - Brasil.

GRÁFICO 27- Média de horas semanais de jornada de trabalho das mulheres da Bolívia, segundo tipo de emprego, nos anos de 2000 e 2013.

GRÁFICO 28 - Taxa de atividade feminina segundo posições na família, nos anos de 1980, 1990 e 2002 - Brasil

GRÁFICO 29 - Jornada de trabalho por sexo segundo pessoas ocupadas na Bolívia, no ano de 1999.

GRÁFICO 30 - Porcentagem de mulheres segundo a hierarquia funcional dos

estabelecimentos distribuído por lugar da pesquisa, referente ao período de 15 a 23 de março de 2013.

GRÁFICO 31 - Total de mulheres segundo faixa etária distribuído por lugar pesquisado, período de abrangência corresponde a 15 a 23 de março de 2013.

GRÁFICO 32 - Mulheres que trabalham nas cidades-gêmeas de fronteira, segundo estado civil, por nacionalidade, referente ao período de 15 a 23 de março de 2013... 176 GRÁFICO 33 - Porcentagem de mulheres bolivianas segundo faixa etária e por principal motivo de trabalhar na área de fronteira, período de 15 a 23 de março de 2013.

GRÁFICO 34 - Porcentagem de mulheres brasileiras segundo faixa etária e por principal motivo de trabalhar na área de fronteira, período de 15 a 23 de março de 2013.

GRÁFICO 35 - Principais produtos de exportação do departamento de Santa Cruz, segundo principais países de destino, valores em moeda americana (US\$ FOB), ano de 2014. 
GRÁFICO 36 - Importação de Alimentos e Bebidas do Departamento de Santa Cruz, segundo principais locais de entrada, por ano de 2000 a 2014, valores em moeda americana (US\$ FOB).

GRÁFICO 37 - Número de estabelecimentos comerciais do ramo varejista e atacadista da cidade de Corumbá, Mato Grosso do Sul, segundo os anos de 1988 a 1995 e 2001 a 2012. 


\section{Lista de Ilustrações}

FIGURA 1 - Localização do município de Corumbá no estado de Mato Grosso do Sul/Brasil e municípios de Puerto Suarez e Puerto Quijarro no departamento de Santa Cruz/Bolívia, segundo divisão política do Brasil, por unidade federativa e divisão política da Bolívia, por departamento

FIGURA 2 - Brasil (Corumbá/Mato Grosso do Sul) e Bolívia (Puerto Quijarro e Puerto Suarez/departamento de Santa Cruz) imagem de satélite das cidades-gêmeas na fronteira internacional

FIGURA 3 - Brasil (Corumbá/Mato Grosso do Sul) imagem de satélite do maciço do Urucum no município de Corumbá localizado na margem direita do rio Paraguai. ...... 25 FIGURA 4 - Bolívia, Puerto Quijarro, imagem de satélite da avenida Luis Salazar de La Vega.

FIGURA 5 - Bolívia, Puerto Quijarro, avenida Luis Salazar De La Vega, imagem de satélite do Shopping de Puerto Aguirre.

FIGURA 6 - Bolívia, Puerto Quijarro, avenida Luis Salazar De La Vega, imagem de satélite do Centro Comercial 12 de Octubre (Feirinha da Bolívia) e demais estabelecimentos comerciais da linha de fronteira.

FIGURA 7 - Bolívia, Puerto Suarez, imagem de satélite da avenida Bolívar com acesso pela rodovia boliviana "Ruta Nacional 4".

FIGURA 8 - Brasil, Corumbá, imagem de satélite da rua Dom Aquino e Treze de Junho e das principais ruas que formam o quadrilátero central constituído pelas ruas Frei Mariano, Delamare, Quinze de Novembro.

FIGURA 9 - Total de mulheres distribuída em Corumbá, Puerto Quijarro e Puerto Suarez por local de nascimento, referente ao setor de comércio varejista. Período de abrangência corresponde a 15 a 23 de março de 2013.

FIGURA 10 - Fluxo do comércio de roupas e calçados da Bolívia

FIGURA 11 - Valor Bruto da Produção (em moeda Bs\$) por atividade (\%) segundo departamento, ano de 2010, Bolívia.

FOTO 1- Bolívia, Arroyo Concepción em Puerto Quijarro, prédios comerciais que abrigam trabalhadoras temporárias denominadas de "cama adentro"

FOTO 2 - Bolívia, Arroyo Concepción em Puerto Quijarro, Calle 12 de Octubre, principal centro comercial de produtos populares, fotografado em agosto de 2008 ..... 79 FOTO 3 - Bolívia, Arroyo Concepción em Puerto Quijarro, Calle 12 de Octubre, principal centro comercial de produtos populares, fotografado em agosto de 2008 ..... 80 FOTO 4 - Bolívia, Arroyo Concepción em Puerto Quijarro, Calle 12 de Octubre, principal centro comercial de produtos populares, fotografado em setembro de 2014. . 81 FOTO 5 - Bolívia, Arroyo Concepción em Puerto Quijarro, Calle 12 de Octubre, principal centro comercial de produtos populares, fotografado em setembro de 2014.. 81 
FOTO 6 - Bolívia, Arroyo Concepción em Puerto Quijarro, lado esquerdo da Calle 21 de Septiembre, principal centro comercial de produtos populares, fotografado em agosto de 2008.

FOTO 7 - Bolívia, Arroyo Concepción em Puerto Quijarro, lado direito da Calle 21 de Septiembre, principal centro comercial de produtos populares, fotografado em agosto de 2008.

FOTO 8 - Bolívia, Arroyo Concepción em Puerto Quijarro, Calle 21 de Septiembre, principal centro comercial de produtos populares, fotografado em setembro de 2014.. 85 FOTO 9 - Bolívia, Arroyo Concepción em Puerto Quijarro, casas de câmbio na linha de fronteira 86 FOTO 10 - Bolívia, Arroyo Concepción em Puerto Quijarro, banco público na linha de fronteira, Ruta Nacional 4 FOTO 11 - Bolívia, Arroyo Concepción em Puerto Quijarro, Ruta Nacional 4, principal rodovia de acesso a Santa Cruz de la Sierra e a cidade de Corumbá/Brasil, fotografado em agosto de 2008.

FOTO 12 - Bolívia, Arroyo Concepción em Puerto Quijarro, Ruta Nacional 4, principal rodovia de acesso a Santa Cruz de la Sierra e a cidade de Corumbá/Brasil, fotografado em setembro de 2014 .

FOTO 13 - Bolívia, Arroyo Concepción em Puerto Quijarro. Mulheres indígenas no

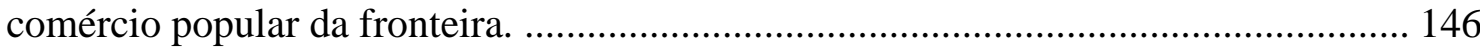
FOTO 14 - Bolívia, Puerto Quijarro, área interna do "Shopping Puerto Aguirre". .... 154 FOTO 15 - Bolívia, Puerto Quijarro, área interna do "Centro comercial 12 de Octubre".

FOTO 16 - Bolívia, Puerto Quijarro, estacionamento de vans brasileiras no "Centro comercial 12 de Octubre".

FOTO 17 - Bolívia, Puerto Quijarro, estacionamento de vans do "Centro comercial 12

de Octubre".

FOTO 18 - Puerto Quijarro, prestadora de serviço brasileira.

FOTO 19 - Bolívia, Puerto Suarez, avenida Bolívar, fachada de estabelecimentos comerciais da década de 1980 a 1990 da faixa de fronteira.

FOTO 20 - Bolívia, Puerto Suarez, avenida Bolívar, fachada de estabelecimentos comerciais da década de 1980 a 1990 da faixa de fronteira.

FOTO 21 - Puerto Suarez, comércio popular ao redor do "Mercado municipal Nuestra

Señora El Carmem",

FOTO 22 - Bolívia, Puerto Suarez, comércio popular ao redor do "Mercado municipal

Nuestra Señora El Carmem".

FOTO 23 - Corumbá, rua Delamare, área central.................................................. 166

FOTO 24 - Corumbá, rua Frei Mariano na área central ............................................ 167

FOTO 25 - Corumbá, área externa da Feira Brasil-Bolívia (Brasbol), extinta em maio de 2013.

FOTO 26 - Corumbá, vendedora ambulante de artesanato na rua Dom Aquino, área central

FOTO 27 - Brasil, Corumbá, Feira Brasbol, área destinada à comercialização de produtos de exportação provenientes de várias fronteiras da Bolívia. 
FOTO 28- Brasil, Corumbá, rua Dom Aquino, prédio residencial e comercial, estabelecimento de produtos diversos

FOTO 29 - Brasil, Corumbá, rua Dom Aquino, prédio residencial e comercial, estabelecimento de produtos diversos

FOTO 30 - Bolívia, Arroyo Concepción em Puerto Quijarro, “tienda” de produtos

diversos na avenida Luis Salazar de la Vega, situado na linha de fronteira................. 217 FOTO 31- Bolívia, Puerto Suarez, reforma do Mercado Popular "Nuestra Señora Del

Carmen", situado na faixa de fronteira. 218 


\section{Listas de Siglas}

ALADI - Asociación Latinoamericana de Integración

CAN - Comunidade Andina de Nações

IBGE - Instituto Brasileiro de Geografia e Estatística

INE - Instituto Nacional de Estadística

MS - Mato Grosso do Sul

OIT - Organização Internacional do Trabalho

OMC - Organização Mundial do Comércio

PDM - Programa de Desarrollo Municipal

PNAD - Pesquisa Nacional de Amostra de Domicílio

SEMAC - Secretaria de Estado de Meio Ambiente, Planejamento, da Ciência e Tecnologia 


\section{Sumário}

RESUMO

ABSTRACT

LISTA DE TABELAS

LISTA DE GRÁFICOS

LISTA DE ILUSTRAÇÕES

LISTAS DE SIGLAS

INTRODUÇÃO

CAPÍTULO 1

1.1 Fronteiras: algumas definições e discussões geográficas

1.2. Os períodos da formação socioeconômica da fronteira oeste brasileira

1.2.1 A fronteira colonial e a importância da atividade comercial para delimitação da linha de fronteira entre Brasil e Bolívia.

1.2.2 A fronteira oeste brasileira na fase republicana e a "satelização" da Bolívia.

1.2.3 A fronteira da "vivificação" e as estratégias de planificação das faixas de fronteira entre Brasil e Bolívia.

1.2.4 O novo dinamismo da fronteira entre Brasil e Bolívia.

1.2.4.1. A distribuição populacional da fronteira oeste brasileira e da fronteira oriental boliviana 58

1.2.4.2. Vetores organizativos da fronteira: taxa de câmbio, nível dos salários mínimos e preços dos produtos de commodities. 
3.1. Questões teóricas e metodológicas sobre o espaço feminino a partir do olhar geográfico

3.1.2 A produção do espaço transfronteiriço das cidades-gêmeas Corumbá, Puerto Quijarro e Puerto Suarez: uso da mão de obra feminina.

3.2. As práticas comerciais Aymaras e as mulheres "cama adentro" na fronteira entre Brasil e Bolívia

3.2.1.1. Os investimentos duplicados nas cidades-gêmeas Corumbá (Mato Grosso do Sul), Puerto Quijarro e Arroyo Concepción (departamento de Santa Cruz)

3.2.2. As trabalhadoras brasileiras nas cidades fronteiriças da Bolívia 


\section{INTRODUÇÃO}

Esta pesquisa que se apresenta teve início no ano de 2005, quando a pesquisadora começou a estudar as cidades-gêmeas de fronteira ${ }^{1}$. Este tema fazia parte da demanda de pesquisa do governo brasileiro para desenvolver projetos binacionais, especialmente, para cidades-gêmeas de fronteira. Naquele momento, a pesquisadora teve a felicidade de participar de um grupo de pesquisa que se propôs a estudar as cidades-gêmeas de fronteira com o estado de Mato Grosso do Sul, foi quando ficou estabelecida a cidade de Ponta Porã com Pedro Juan Caballero, no Paraguai, como projeto de investigação inicial. Logo surgiu a necessidade de se estudar outra cidade fronteiriça. O que levou a pesquisar a cidade de Corumbá do lado brasileiro e as cidades bolivianas Puerto Quijarro e Puerto Suarez, na linha da fronteira ${ }^{2}$.

Fatos da vida profissional desta autora levaram-na até a cidade de Corumbá no ano de 2007, desde então, ela tem realizado observações, mantido diálogos com os atores fronteiriços, coletado informações, registrado imagens que, de alguma forma, possibilitam compreender a dinâmica das relações fronteiriças. Várias formas de coleta de dados foram utilizadas e realizadas sob condições adversas. Assim que se instalou em Corumbá, a pesquisadora adotou a rotina de ir às cidades bolivianas de fronteira aos sábados, dia de maior circulação de sacoleiras, turistas e da população local. A partir desta situação, ela se propôs a conversar informalmente com cada um desses atores e, desde então, pôde perceber que essa circulação tinha direção e volume distintos.

Durante as observações para a pesquisa, ficou constatado que as sacoleiras se deslocavam apenas para o centro comercial popular, restrito à linha de fronteira, especificamente entre as Calles 12 de Octubre e 11 de Septiembre, em Arroyo Concepción, que pertencem ao município de Puerto Quijarro. Além disso, o comércio de

\footnotetext{
${ }^{1}$ A fim de caracterizar as cidades-gêmeas e evidenciar a importância de estudos sobre a fronteira, Machado (2005) esclarece que: "estes adensamentos populacionais, cortados pela linha de fronteira, seja esta seca ou fluvial, articulada ou não por obra de infraestrutura, apresentam grande potencial de integração econômica e cultural assim como manifestações localizadas dos problemas característicos da fronteira” (Machado, 2005, p.274).

${ }^{2}$ Com base na tipologia de cidades-gêmeas entre a fronteira do Brasil e da Bolívia, Machado as descreve como uma "situação geográfica de fronteira seca (...) do tipo de interação capilar, onde as trocas são difusas e emergem espontaneamente entre as aglomerações e que podem evoluir no sentido de integração sem patrocínio governamental, seja na construção de infraestrutura de articulação transfronteiriça, seja na realização de acordos bilaterais" (Machado, 2005, p.275).
} 
vestuário se destacava entre as mercadorias mais procuradas, era muito comum entre as sacoleiras a prática de ultrapassar a cota estabelecida pela aduana brasileira.

Nos feriados nacionais, estaduais e calendários festivos da cidade de Corumbá, uma leva de turistas se deslocava até Puerto Aguirre, onde está sediado o Shopping de Aguirre, lá encontravam diversos produtos importados, como bebidas, perfumes, relógios, eletrônicos, material de pesca, entre outros. A quantidade de produtos adquiridos dependia da variação da moeda americana, pelo fato de ser uma zona comercial de importados os preços são cotados em dólares. Alguns se arriscavam e levavam a quantidade acima da cota permitida, isso acontecia quando o poder de compra da moeda brasileira estava alto.

A população local, corumbaenses e ladarenses, além de frequentar o centro comercial popular e o Shopping de Aguirre, segue mais adentro e se desloca até Puerto Suarez, cidade fronteiriça a $15 \mathrm{~km}$ de Corumbá, para fazer compras em supermercados, especialmente no Supermercado Tocalle, situado na Avenida Bolívar, no centro da cidade, lá, a despensa da casa era abastecida com produtos alimentícios, de limpeza até decoração, eletrodomésticos e eletrônicos.

Os preços dos produtos desse supermercado são marcados em moeda boliviana e americana, o que influenciava na quantidade a ser adquirida pelos clientes brasileiros, mas a maioria usava a moeda boliviana em espécie, o que possibilita a conversão em mais produtos, uma vez que a moeda brasileira é mais valorizada do que a boliviana. As mulheres cambistas que estão localizadas na linha da fronteira realizavam as trocas das moedas para os brasileiros que seguiam para Puerto Suarez.

Dentre as observações relatadas a que mais se destacou foi a presença majoritária de mulheres, que se movimentavam num esforço diário e exaustivo sob a temperatura de $30^{\circ} \mathrm{C}$ na média anual, para fazer circular as mercadorias do centro comercial popular. À primeira vista, percebeu-se que se tratavam de mulheres provenientes das cidades do altiplano boliviano e de Santa Cruz de la Sierra, que se deslocavam pelo menos uma vez na semana ou no mês, de trem ou ônibus, com destino às cidades de fronteira para vender suas mercadorias.

A partir disso, foi identificada a rota do comércio de roupas como procedente do mercado atacadista e varejista das ruas de Santa Cruz de la Sierra, que se configura como 
principal centro importador de mercadorias de portos chilenos e peruanos. Portanto, a ideia central desta investigação tem como interface o circuito de produção de confecção e o circuito comercial transfronteiriço ${ }^{3}$.

Para dar prosseguimento a essa introdução, segue a descrição da localização da pesquisa que tem a intenção de situar as cidades-gêmeas na fronteira entre Brasil e Bolívia e, assim, delimitar o objeto a ser investigado.

O território boliviano está organizado em departamentos, províncias, municípios e cantões. Os municípios de Puerto Suarez e Puerto Quijarro, escolhidos pela pesquisa, estão localizados no extremo sudeste do departamento de Santa Cruz, fazem parte da província de German Bush e estão aproximadamente a 600 km de distância de Santa Cruz de la Sierra ${ }^{4}$, capital do departamento. E do lado brasileiro, cuja organização política está dividida em estados federados, municípios e o Distrito Federal, o município de Corumbá se localiza a oeste do estado de Mato Grosso do Sul e a cidade de Corumbá está a 420 km de distância da capital Campo Grande ${ }^{5}$.

\footnotetext{
${ }^{3}$ Trata-se das relações comerciais, produtivas e culturais que aproximam as cidades-gêmeas da fronteira entre Brasil e Bolívia. Tais relações se intensificam com as ações e interesses dos atores responsáveis pela circulação de produtos e pessoas para além dos limites fronteiriços, portanto, transfronteiriço.

${ }^{4}$ A capital do departamento de Santa Cruz concentra $16 \%$ da população do país e o Departamento totaliza $370.621 \mathrm{~km}^{2}$ que representa $34 \%$ do território boliviano (INE, 2011).

${ }^{5}$ A capital do estado de Mato Grosso do Sul (MS) possui 843.120 habitantes e o estado de MS totaliza $357.145,532 \mathrm{~km}^{2}$ que representa 4,2\% do território brasileiro (IBGE, 2014)
} 


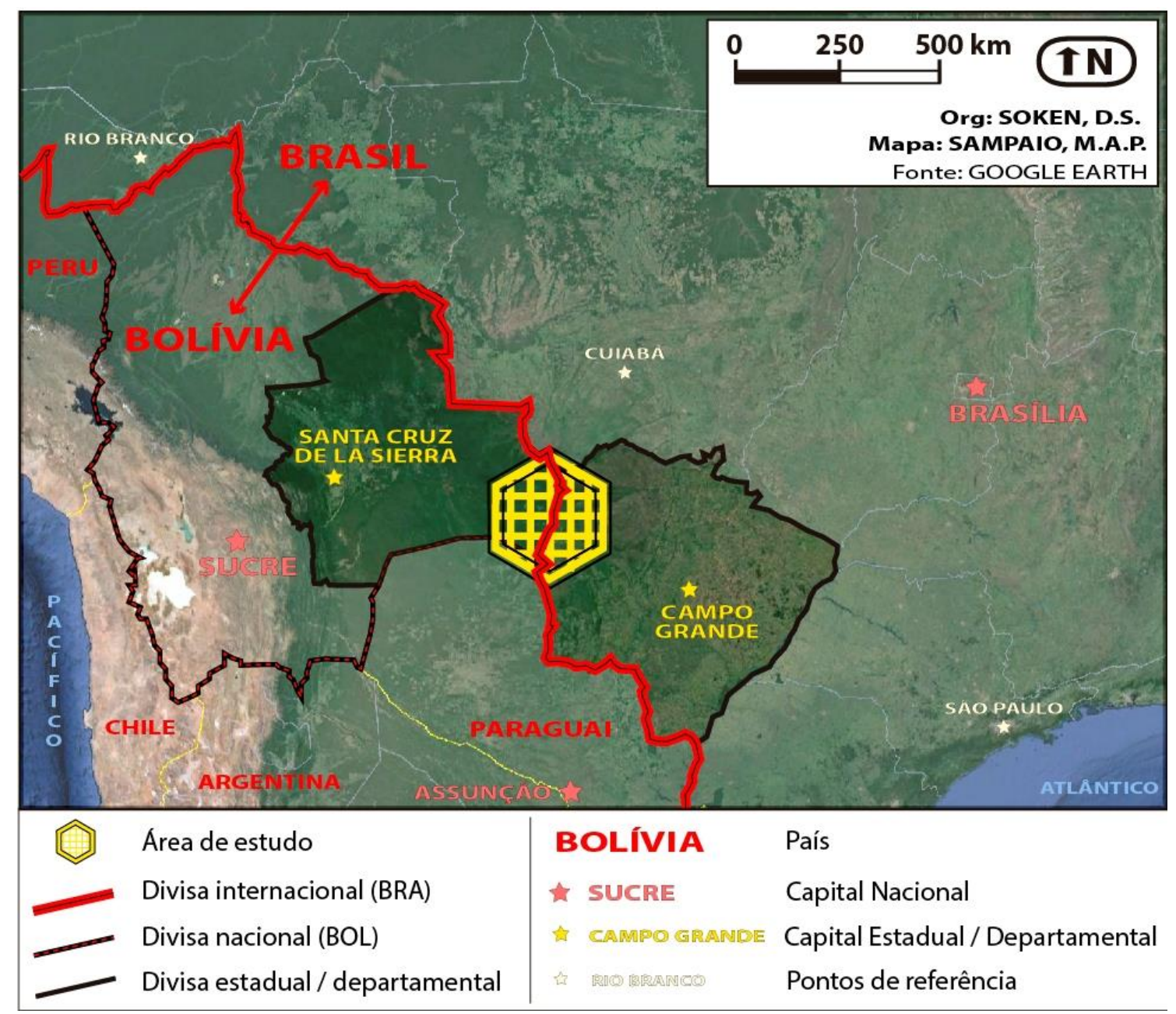

FIGURA 1 - Localização do município de Corumbá no estado de Mato Grosso do Sul/Brasil e

municípios de Puerto Suarez e Puerto Quijarro no departamento de Santa Cruz/Bolívia, segundo divisão política do Brasil, por unidade federativa e divisão política da Bolívia, por departamento.

Fonte: Google Earth

Organização: SOKEN, D. S.

Elaboração: SAMPAIO, M.A.P.

O espaço da pesquisa contempla uma população urbana de 1.568 .564 pessoas distribuídas territorialmente na linha de fronteira e na capital cruceña, nesta residem 1.442.396 almas e nas cidades-gêmeas da fronteira entre Brasil e Bolívia moram 126.168 cidadãos. Com destaque a cidade de Corumbá que concentra $74 \%$ da população da área da pesquisa, enquanto que as cidades bolivianas Puerto Suarez e Puerto Quijarro participam com 12,95\% e 13,05\% respectivamente (IBGE, 2010; INE, 2012).

Em termos de dimensão do território, destaque para o município de Corumbá, que totaliza $64.962,8 \mathrm{~km}^{2}$, o que representa $18,2 \%$ da área do estado de Mato Grosso do Sul, no entanto, sua densidade demográfica é de apenas 1,6 habitantes por km² (IBGE, 2010). O município de Puerto Suarez totaliza 9.406,46 km² e Puerto Quijarro com uma extensão de $2.033 \mathrm{~km}^{2}$ ao todo representam $3 \%$ da área do departamento de Santa Cruz, o primeiro 
tem a densidade populacional de 2,21 habitantes por $\mathrm{km}^{2}$ e o segundo apresenta a densidade populacional de 8,58 habitantes por $\mathrm{km}^{2}$ (PDM, 2006).

A FIGURA 02 "Brasil (Corumbá/Mato Grosso do Sul) e Bolívia(Puerto Quijarro e Puerto Suarez/ departamento de Santa Cruz) imagem de satélite das cidades-gêmeas na fronteira internacional” e a FIGURA 03 "Brasil (Corumbá/Mato Grosso do Sul) imagem de satélite do maciço do Urucum no município de Corumbá localizado na margem direita do rio Paraguai” revelam que a cidade de Corumbá está estrategicamente localizada à margem direita do rio Paraguai e faz limite internacional com as cidades bolivianas. Apenas 4 km separam Corumbá de Puerto Quijarro e 15 km de Puerto Suarez, cujo limite se faz pela fronteira seca. O acesso pela rodovia brasileira (BR-262) liga a faixa de fronteira ao território brasileiro, contornando o Maciço do Urucum que é formado pela Serra do Amolar ao norte. As rochas do Grupo Jacadigo (Formação Urucum e Santa Cruz) compõem as principais jazidas minerais do estado de MS, são o ferro e o manganês ${ }^{6}$ (SEMAC/MS, 2009, p.13) o que faz Mato Grosso do Sul participar com 13\% da reserva nacional de minério de ferro e 14,6\% na produção nacional de manganês (BRASIL, 2014, p.70 e 86$)^{7}$.

\footnotetext{
${ }^{6}$ MATO GROSSO DO SUL. Secretaria de Estado de Meio Ambiente, do Planejamento, da Ciência e Tecnologia. Diagnóstico Socioeconômico de Mato Grosso do Sul. Campo Grande, MS, 2009.

${ }^{7}$ BRASIL. Departamento Nacional de Produção Mineral. Sumário mineral. Brasília, DNPM, 2014.
} 


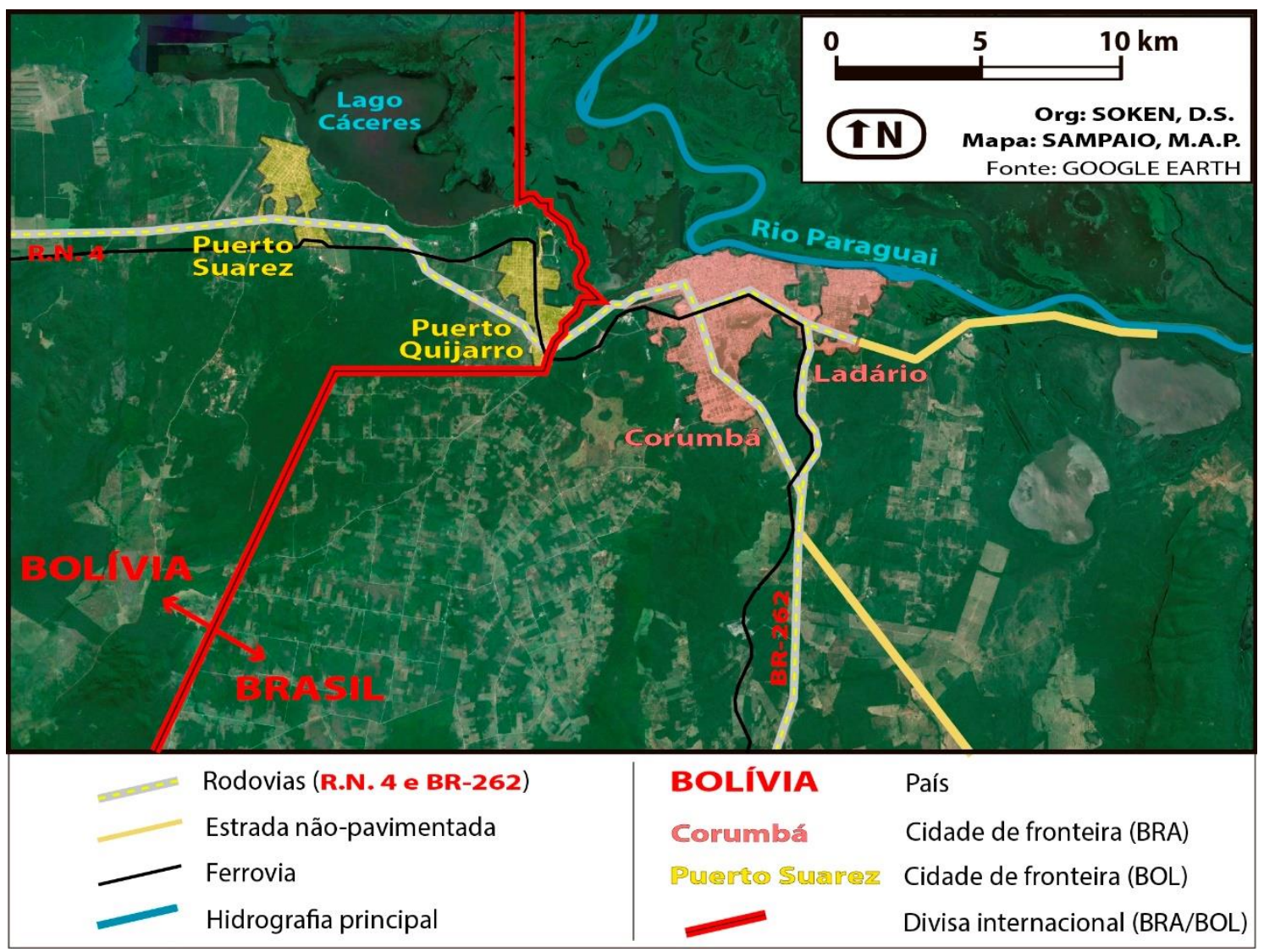

FIGURA 2 - Brasil (Corumbá/Mato Grosso do Sul) e Bolívia (Puerto Quijarro e Puerto

Suarez/departamento de Santa Cruz) imagem de satélite das cidades-gêmeas na fronteira internacional Fonte: Google Earth

Além disso, pode-se observar, na FIGURA 2, o Canal do Tamengo importante acesso da Bolívia para o mar, por meio do rio Paraguai. O Acordo de Santa Cruz de la Sierra assinado em 1992 concedeu à Bolívia plenas condições de navegação e transporte comercial, fluvial e longitudinal pela Hidrovia Paraguai - Paraná, desde o Porto de Cáceres, no Mato Grosso, até o Porto de Nueva Palmira, no Uruguai (ALADI, 1992) ${ }^{8}$. Esse acordo alavancou o setor de agronegócios localizado na zona oriental do departamento de Santa Cruz até a fronteira com o Brasil. O projeto denominado "Tierras Bajas del Leste", elaborado na década de 1980, recebeu apoio do Banco Mundial para o plantio de soja (PUERTO AGUIRRE, 2007) ${ }^{9}$. Sobretudo, com os investimentos na produção de petróleo e alimentos no departamento de Santa Cruz, nas décadas de 1960 e 1970, desencadearam novo processo de colonização com migrantes da parte ocidental da Bolívia para as tierras bajas no lado oriental (SANDOVAL ARENAS, 2013.

\footnotetext{
${ }^{8}$ ALADI/AAP/A14TM/5. Acordo de Santa Cruz de la Sierra. Valle de las Leñas, Argentina, 1992. Acesso por: www.dpc.mar.mil.br/sites/default/files/ssta/legislacao/hidrovia/acordotr.pdf

${ }^{9}$ PUERTO AGUIRRE. 2007. Acesso por: http://www.puertoaguirre.com
} 


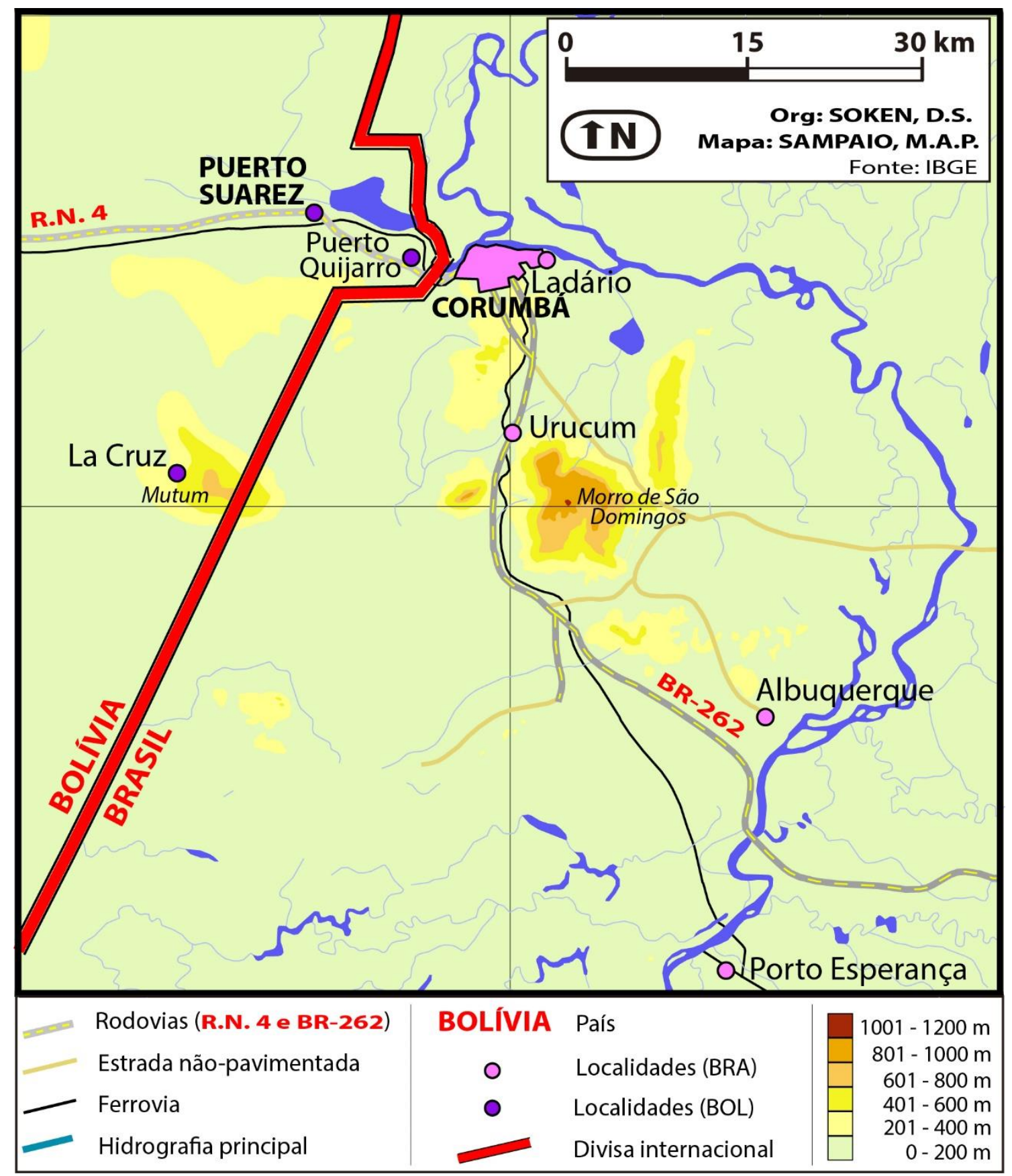

FIGURA 3 - Brasil (Corumbá/Mato Grosso do Sul) imagem de satélite do maciço do Urucum no município de Corumbá localizado na margem direita do rio Paraguai.

Fonte: Google maps, 2015

No que diz respeito ao lugar da pesquisa, observou-se três aspectos. O primeiro foi a importância do processo de migração internacional e regional, portanto da diversificação étnica da população feminina onde a maioria descende de indígenas da 
parte alta ${ }^{10}$ e da parte oriental ${ }^{11}$ da Bolívia e brasileiras procedentes de vários lugares do estado de Mato Grosso do Sul e de fora dele.

O segundo está relacionado ao impacto de pelo menos duas políticas macroeconômicas brasileiras sobre as relações de fronteira, sendo elas: a abertura comercial para produtos importados em 1992 e a implantação da política econômica de estabilização monetária em 1994. Ambas resultaram em aumento de oferta de produtos importados a preços mais competitivos, bem como em maior capacidade de poder de compra da moeda brasileira. Essa combinação de políticas conjunturais estimulou a ampliação de "fixos e fluxos"12 nas cidades de fronteira e implicou em novo ordenamento territorial.

O terceiro diz respeito à nova Divisão Internacional do Trabalho na fronteira. Pode-se dizer que a expansão do comércio transfronteiriço de todos os tipos de produtos até as cidades-gêmeas de fronteira ocorre a partir da década de 1980. Nas décadas seguintes, assistiu-se ao surgimento de vários outros empreendimentos que se voltavam para a fronteira, como por exemplo, a construção do porto fluvial em Puerto Quijarro na divisa entre Brasil e Bolívia, que possibilita o escoamento dos produtos bolivianos para o mercado internacional, bem como, os novos atores industriais que incrementam a base produtiva destas localidades com a instalação de empresas de extração de minério mediante investimentos de empresas multinacionais.

Desta forma, esta pesquisa tem como objetivo principal, tomando como ponto de partida as transformações econômicas, políticas e sociais verificadas a partir da década de 1990, compreender como o trabalho feminino contribui para a (re) produção do espaço numa região de fronteira, constituída pelas cidades-gêmeas Corumbá (MS), no Brasil; Puerto Quijarro e Puerto Suarez, na Bolívia.

Ainda, o presente estudo visa contribuir para as discussões sobre "Gênero e Fronteira", a partir da análise da divisão sexual do trabalho transfronteiriço, bem como,

\footnotetext{
${ }^{10}$ As bolivianas provenientes dos departamentos da parte alta da Bolívia são de: La Paz, Cochabamba e Oruro.

${ }^{11}$ Aquelas do lado oriental são predominantemente da capital Santa Cruz da La Sierra.

12 Ver Santos, M. Técnica, Espaço, Tempo: Globalização e Meio Técnico-Científico Informacional. São Paulo: Ed. Hucitec, 1994
} 
busca entender a organização do trabalho feminino na fronteira internacional e por quais razões ocorre a concentração dessa mão de obra nessa localidade.

Além disso, este estudo procurou, com base no desenvolvimento de uma metodologia consistente, gerar conhecimento científico sobre a dinâmica do território fronteiriço, a fim de elaborar indicadores socioeconômicos que possam auxiliar a compreensão da (re) produção do espaço de fronteira. Pretende-se compartilhar as informações levantadas e analisadas sobre o trabalho feminino na fronteira com as diversas associações e representações de classes dos municípios supracitados, com o objetivo de colaborar na proposição de políticas públicas voltadas tanto para as mulheres quanto para as ações que visam ao desenvolvimento regional.

Recentemente, observa-se o crescimento do número de pesquisas sobre fronteiras internacionais, pois é cada vez maior a presença de comunidades de fronteira, o que pode provocar conflitos, considerando que "cada lugar quer estender sua esfera de influência e reforçar sua centralidade além dos limites internacionais e sobre as faixas de fronteiras" (MACHADO, 1998, p.8). Mas o que é a fronteira? Como esse conceito tem sido debatido no âmbito da Geografia.

A fronteira, segundo Raffestin (2005):

(...) não é uma linha, a fronteira é um dos elementos da comunicação biossocial que assume, uma função reguladora. Ela é a expressão de um equilíbrio dinâmico que não se encontra somente no sistema territorial, mas em todos os sistemas biossociais (RAFFESTIN, 2005, p. 13).

Como afirmou Raffestin (1993, p. 169) “o limite é uma necessidade incontornável". Assim, os limites internacionais, embora não tenham mais o efeito sobre o "cotidiano vivido", são a garantia da identidade territorial (MACHADO, 1998, p.10).

As contribuições de Raffestin (1993, p.168) nos permitem compreender, ainda, a fronteira a partir da análise da linha fronteiriça, classificando-a em função legal, de controle, fiscal e ideológica ou militar, termos que possibilitam construir um sistema hierárquico de fronteiras que revela as relações de poder existentes no território.

Observou-se que, dentre todas as funcionalidades possíveis da linha de fronteira, a função legal, mediante a presença de instituições, é a que mantém mais estáveis as relações nas fronteiras internacionais. Enquanto, as funções de controle e fiscal são 
relações virtuais que podem vir a dinamizar os fluxos econômicos (RAFFESTIN, 1993, p.168).

A fim de entender as recentes transformações da dinâmica espacial, partiu-se da teoria do espaço de Santos (1994), que remete ao "período técnico-científicoinformacional" e menciona a necessidade de se discutir a categoria "tempo" e assim "reconhecer o lugar de cada país no conjunto do planeta".

Esse período retratado pelo fenômeno da 'globalização' da sociedade e da economia, segundo Santos (2012), “acarreta a mundialização do espaço geográfico, carregando-o de novo significado". E a partir da caracterização dos "sistemas de objetos e ações", que retratam as transformações do espaço geográfico, remete as análises a uma escala mundial.

Observa-se uma nova organização territorial que se faz presente na faixa de fronteira, dada pelas cidades-gêmeas Corumbá (lado brasileiro), Puerto Suarez e Puerto Quijarro (lado boliviano). Conforme Oliveira (2008):

A condição fronteiriça marca a região, criando a possibilidade de formação de outra identidade. A hegemonia das circulações advindas das complementaridades (capital, trabalho, terra e serviços, segundo House, 1980) entre brasileiros e bolivianos consolida um cotidiano que, mesmo absorvido para um comportamento coletivo muito próximo, seja de aversão ou de acessão (OLIVEIRA, 2008, p. 248).

Ao elaborar a metodologia de pesquisa na área de fronteira entre Brasil e Bolívia deparou-se com inúmeros desafios, destaque para os seguintes: a) o primeiro foi a sistematização e a análise de dados sobre as cidades-gêmeas de distintas nacionalidades; b) o segundo foi a introdução da abordagem de gênero como categoria de análise capaz de iluminar a compreensão do processo conflituoso e contraditório de (re) produção do espaço transfronteiriço formado pelas cidades-gêmeas Corumbá (Brasil), Puerto Suarez e Puerto Quijarro (Bolívia). Estes problemas metodológicos foram encontrados ao longo do trabalho de investigação e resolvidos, por vias conceituais e/ou por fontes primárias reveladas durante a coleta de dados.

Com base nos conceitos referentes aos Circuitos Espaciais de Produção discutidos por Milton Santos conseguiu-se avançar no entendimento da circulação de pessoas e mercadorias do espaço de fronteira. Conforme Santos (2011): 
Circuitos espaciais de produção e círculos de cooperação mostram o uso diferenciado de cada território por parte das empresas, das instituições, dos indivíduos e permitem compreender a hierarquia dos lugares desde a escala regional até a escala mundial (SANTOS, 2011, p.144).

Ainda, Santos (2011) permite pensar para além do entendimento de fronteira apenas como faixa ou limite, quando nos possibilita afirmar que o território é onde acontecem as relações transfronteiriças, portanto,

(...) para entender o funcionamento do território é preciso captar o movimento, daí a proposta de abordagem que leva em conta os circuitos espaciais da produção. Estes são definidos pela circulação de bens e produtos e, por isso, oferecem uma visão dinâmica, apontando a maneira como os fluxos perpassam o território (SANTOS, 2011, p.143).

A pesquisadora realizou a análise dos dados assimétricos das cidades-gêmeas da fronteira entre Brasil e Bolívia amparada neste referencial teórico, porque segundo Santos: “(...) há uma crescente segmentação territorial das etapas do trabalho, intensificando-se as trocas e relações entre as regiões. Esses intercâmbios frequentes e espessos não são obrigatoriamente entre áreas contíguas" (SANTOS, 2011, p.143).

Compreende-se que as relações fronteiriças da área de estudo em questão vão além da faixa de fronteira, pois há complementariedade com os fluxos de espaços nacionais e globais. Para demonstração desse estudo de caso da área de fronteira entre Brasil e Bolívia, inseriu-se a discussão do circuito espacial de produção têxtil e confecção que utiliza de mão de obra feminina na produção e circulação de mercadorias. Conforme, observa Santos:

No período atual, esse movimento é comandado sobretudo por fluxos não obrigatoriamente materiais, isto é, capitais, informações, mensagens ordens. Essa é a inteligência do capital, reunindo o que o processo direto da produção havia separado em diversas empresas e lugares, mediante o aparecimento de verdadeiros círculos de cooperação (SANTOS, 2011, p. 144).

Durante o processo de desenvolvimento desta pesquisa, percebeu-se que na nova dinâmica fronteiriça, pensada a partir do movimento das contradições entre o "novo e o velho ${ }^{13}$, houve a intensificação das relações comerciais, produtivas e culturais, entre Bolívia-Brasil, cujo processo de acumulação de capital se reproduz mediante uso da força de trabalho feminina.

\footnotetext{
${ }^{13}$ Ver SANTOS, M. Metamorfoses do Espaço Habitado. 6.ed. 1. Reimpr.São Paulo: Edusp, 2012.
} 
Santos e Silveira (2011, p. 167), no capítulo VII intitulado "Por uma geografia do movimento", propõem elevar o debate sobre circulação, pois:

Com a produção do meio técnico-científico-informacional, os círculos de cooperação instalam-se em um nível superior de complexidade e numa escala geográfica de ação bem mais ampla. Hoje não basta produzir. É indispensável pôr a produção em movimento, pois agora é a circulação que prescinde à produção (SANTOS e SILVEIRA, 2011, p.167).

Portanto, a partir da abordagem crítica de Milton Santos e Maria Laura Silveira sobre "a dialética entre a frequência e a espessura dos movimentos no período contemporâneo e a construção e modernização dos aeroportos, portos, estradas, ferrovias e hidrovias" (SANTOS e SILVEIRA, 2011, p.167), é possível entender a importância do espaço de fronteira nas políticas territoriais de integração sul-americana, pensada segundo Wanderley Costa (2008, p.3) como uma estratégia de inserção ativa no acelerado processo de reestruturação global. Conforme evidencia Costa (2008), a articulação ativa entre Bolívia e Brasil tem ocorrido mediante investimentos em infraestrutura concentrada entre os departamentos de Santa Cruz, Beni e Pando (Bolívia) e com os estados de Rondônia e Mato Grosso (Brasil).

Sendo assim, a logística do sistema de transporte rodoviário, ferroviário e aéreo com os circuitos espaciais do comércio atacadista e varejista, as redes de energia com a combinação de hidroelétrica e gás natural, a indústria extrativa mineral de ferro, manganês e calcário, os circuitos espaciais de produção de commodities e da indústria têxtil e de confecção e a concentração de mão de obra feminina propiciam vantagens comparativas e competitivas à fronteira, portanto, no momento são esses os elementos estratégicos para o processo de integração transfronteiriço.

Para tanto, esse estudo sobre o espaço de fronteira internacional, que tem o propósito de demonstrar como o trabalho feminino contribui para a (re) produção do espaço transfronteiriço Brasil-Bolívia, realizará uma abordagem sobre a produção do espaço a partir das relações de gênero considerando o conceito da divisão sexual do trabalho. E no que se refere à base teórica metodológica sobre o trabalho feminino na área de fronteira, a pesquisa se orientou pelas análises socioeconômica e espacial.

Entende-se que o trabalho feminino é uma questão de análise do espaço, uma vez que a divisão social do trabalho implica em divisão sexual do trabalho (Rossini, 1988, p. 7). Desta forma, a importância de estudos relacionados ao gênero na Geografia busca 
compreender os impactos dos papéis sociais entre homens e mulheres sobre a organização espacial da sociedade (Rossini, 1988; Calió, 1991).

Considera-se neste estudo, a definição da divisão sexual do trabalho a partir dos dois princípios da divisão social do trabalho, que são: o princípio da separação - há trabalho de homens e trabalho de mulheres; e o princípio hierárquico - o trabalho do homem "vale" mais que o trabalho da mulher. A divisão sexual do trabalho é uma forma historicamente modulada que designa as funções produtivas de maior valor social adicionado para os homens e funções da esfera reprodutiva para as mulheres (HIRATA e KERGOAT, 2008).

No entanto, é importante entender como a presença da força de trabalho feminina nessa fronteira contribui de certa forma para a ampliação e estreitamento das relações fronteiriças, e, portanto, para a reprodução da acumulação do capital mercantil boliviano. Adotou-se a pesquisa qualitativa por meio de observações, imagens fotográficas, reportagens e noticiários da imprensa local, bem como, de entrevistas semi-estruturadas e informais para a coleta de dados nas cidades-gêmeas de fronteira.

E para a análise estatística destacou-se o uso dos dados do Instituto Nacional de Estadística (INE) da Bolívia e do Instituto Brasileiro de Estatística (IBGE); Departamento Intersindical de Estatística e Estudos Econômicos (DIEESE); Instituto de Pesquisa Econômica Aplicada (IPEA), Sistema S - Sebrae, Senai e Senac; prefeitura de Corumbá e alcadías de Puerto Suarez e Puerto Quijarro.

As informações levantadas pela pesquisa foram coletadas com uso de questionários e entrevistas. A pesquisa de campo com aplicação de questionário foi de 15 a 23 de março de 2013. Dentre as atividades do comércio, serviços e indústria foram abordadas ao todo 153 mulheres $^{14}$, sendo 90 no Brasil e 63 na Bolívia, com a faixa etária entre 12 e 62 anos. As entrevistas gravadas foram realizadas em dois períodos de 01 a 10 de setembro de 2014 e no ano de 2015 nos dias 20 a 26 de agosto. Totalizaram 35 entrevistas, com a participação de 26 mulheres, sendo 19 do lado boliviano e 07 do lado

\footnotetext{
${ }^{14} \mathrm{O}$ tempo médio de aplicação do questionário era de 15 a 20 minutos, realizado no próprio local de trabalho.
} 
brasileiro e, também, teve a participação de 09 homens, 03 do lado boliviano e 06 do lado brasileiro.

As entrevistas informais e semi-estruturadas foram concedidas de forma voluntária e espontânea no próprio local de trabalho. Cabe destaque as (os) seguintes entrevistadas (os), foram elas (es): agente consular da Bolívia em Corumbá; administrador do Porto Aguirre; gerentes das lojas do Shopping Aguirre; presidentes do Centro Comercial "12 de Octubre"; presidente da Associação Comercial de Corumbá; agentes de viagem e de turismo de Corumbá, transportadoras de passageiros; gerente de agência bancária; gerente de rede de supermercado de Corumbá; as mulheres comerciantes e prestadoras de serviços do "Centro Comercial 12 de Octubre" e entorno; as mulheres comerciantes e prestadoras de serviços da extinta "Brasbol"; as mulheres comerciantes e prestadoras de serviços da área central de Corumbá; as mulheres comerciantes de feiras livres de Corumbá e as mulheres comerciantes "sacoleiras".

Ao todo o período de levantamento e coleta de dados ocorreu entre os anos de 2008 e 2015, o que possibilitou organizar este estudo em duas etapas. Inicialmente, foi realizada consulta bibliográfica nas seguintes bibliotecas: Florestan Fernandes FFLCH/USP; Faculdade de Economia e Administração - FEA/USP; Faculdade de Arquitetura e Urbanismo - FAU/USP; Faculdade de Educação - FE/USP; Instituto de Psicologia - USP; Escola de Comunicação e Artes - ECA/USP; Instituto de Estudos Brasileiros - IEB/USP; biblioteca Brasiliana da USP; biblioteca da UNB - Brasília e da Universidade Federal de Mato Grosso do Sul, no Câmpus do Pantanal e de Campo Grande. Foram também inúmeras as visitas a site de pesquisa da Bolívia. Dentre institutos de pesquisa e jornais eletrônicos, são os destaques:

- Periódico Digital de Investigación sobre Bolívia: www.pieb.com.bo

- Periódico Digital de Investigación sobre Bolívia: www.corredorpacificoamazonico.pieb.org/

- Jornal eletrônico: www.eldeber.com.bo

- Portal do governo boliviano: www3.abi.bo

- Instituto Nacional de Estadística: www.ine.gob.bo

- Instituto boliviano de comércio exterior: $\underline{w w w . i b c e . o r g . b o}$

- Agência para o desarrollo de las macroregiones e zonas fronterizas: www.ademaf.gob.bo 
- Periódico del Estado Plurinacional de Bolívia: www.cambio.bo

- Programa de las Naciones Unidas para Desarrollo: www.idh.pnud.bo/d7/

Concomitantemente à pesquisa bibliográfica, construiu-se o roteiro de entrevistas e aplicação de questionário com mulheres que atuam em diversas atividades comerciais e de serviços nas cidades-gêmeas. E, na sequência, os resultados da pesquisa de campo foram analisados e descritos para fins de apresentação e debate do estudo em Seminários de Pesquisa no Laboratório de Geografia Política e Planejamento Territorial e Ambiental - LABOPLAN/FFLCH/USP sob a coordenação e orientação da Prof. Dr ${ }^{a}$. Rosa Ester Rossini; Encontros de Geógrafos da América Latina; Simpósio de Gênero; Seminário de Pesquisa América Platina, entre outros. Durante a fase de apresentação e publicação parcial desse estudo foi possível realizar vários ajustes na proposta inicial da pesquisa, surgiram inúmeras contribuições pertinentes às questões conceituais e à operacionalidade dos instrumentos de coleta de dados, e, sobretudo, certificou-se da relevância da temática sobre a fronteira e as questões de gênero, o que oportuniza abrir novas frentes de pesquisa a partir da abordagem geográfica e de gênero.

A partir da tabulação e tratamento dos dados coletados, foram constatadas as seguintes taxas de feminização no comércio varejista das cidades-gêmeas: alimentação (40\%), vestuário (83\%), calçados (72\%), fármaco e cosméticos $(61 \%)$, móveis e eletrodomésticos $(36 \%)$, concessionárias de veículos e motos (52\%), relojoaria (50\%), material de construção (30\%) e livraria (100\%) (Questionário 4 aplicado em março de 2013).

A tese está estruturada em quatro capítulos, sendo os dois primeiros retratam os aspectos históricos e políticos da fronteira internacional entre Brasil e Bolívia, considerando a formação das cidades-gêmeas, sobretudo a importância do circuito espacial produtivo de confecção para retratar o processo de desenvolvimento desse lugar. E os dois últimos capítulos apresentam as formas da organização do trabalho feminino e suas dinâmicas de produção e (re) produção do espaço transfronteiriço. Adiante, segue a descrição de cada capítulo.

No Capítulo 1 será discutido o processo histórico de ocupação da fronteira entre Brasil e Bolívia, em especial sobre a ampliação do comércio fronteiriço das cidadesgêmeas Corumbá, Puerto Quijarro e Puerto Suarez. Compreendeu-se também que a 
fronteira internacional do Brasil se deu por um processo histórico de ocupação. Desta forma, realizou-se uma análise descritiva dos vários períodos de povoamentos e demarcações de limites, até se chegar aos tempos atuais, quando o desenvolvimento do comércio popular rompe com a estagnação desse lugar e impõe nova dinâmica nesse espaço fronteiriço.

Aspectos do trabalho feminino será tratada no Capítulo 2, que tem como propósito discutir a força de trabalho feminina a partir da nova dinâmica de acumulação flexível de capital e, assim, obtermos informações sobre as formas de organização do mercado de trabalho do Brasil e da Bolívia. Inicia-se essa discussão a partir das relações de trabalho na fronteira entre Brasil e Bolívia e tenta-se observar esse fenômeno que se reproduz tanto em função do processo de reestruturação produtiva, que impacta diretamente a estrutura familiar de ambos os países, quanto pelos distintos efeitos da expansão da nova divisão do trabalho. Esta dinâmica imposta pelo novo padrão de acumulação capitalista incorpora o conceito de divisão sexual do trabalho e modifica as relações de trabalho, o que atinge todas as atividades econômicas.

No Capítulo 3 serão apresentadas as formas de organização do trabalho feminino para a (re) produção do espaço transfronteiriço. Com base nas entrevistas e questionários, foram descritas as características e as condições de sobrevivência das mulheres que trabalham nas cidades-gêmeas de fronteira, o que tornou possível conhecer e compreender a contribuição do trabalho feminino para a produção e reprodução deste espaço de fronteira.

E no Capítulo 4 será descrita a lógica do processo de circulação do capital no espaço de fronteira, considerando a lógica de produção do espaço transfronteiriço pelo uso da mão de obra feminina. Sobretudo, o capítulo buscou compreender a circulação do território de fronteira a partir da dinâmica comercial do atacado e varejo entre as cidadesgêmeas e como essa dinâmica intensifica o comércio popular na fronteira, cuja organização é determinada pelas comerciantes bolivianas. 

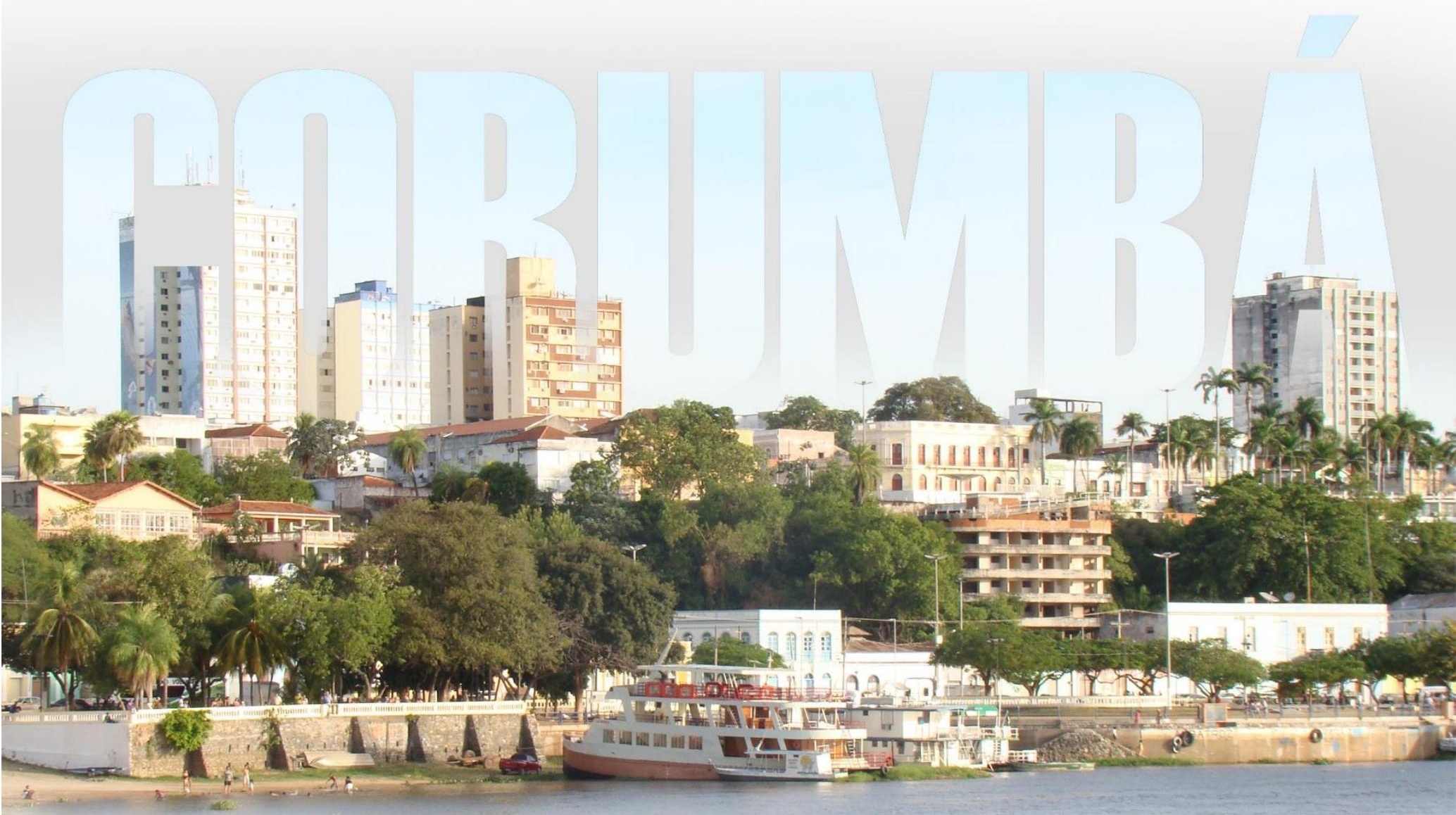

CAPÍTULO 1

DINÂMICAS TERRITORIAIS (IN)VISÍVEIS NA FRONTEIRA BRASIL-BOLÍVIA 
Para se compreender as dinâmicas territoriais contemporâneas que ocorrem nos dias atuais na fronteira Brasil-Bolívia, foram definidos dois períodos recentes que retratam distintos momentos do dinamismo socioeconômico da área de pesquisa. Considerou-se que o primeiro período tem seu início em meados dos anos de 1980. De acordo com Oliveira (2008, p.246), o primeiro período teve como marco a ajuda financeira e técnica do Banco Mundial ao governo boliviano, que alavancou o comércio, o setor industrial e estimulou o cultivo de commodities no departamento de Santa Cruz. Somado a isto, está a pavimentação da BR-262 que interliga a região do Pantanal brasileiro à região Sudeste do país e a qual fortaleceu o corredor São Paulo à cidade de Santa Cruz de La Sierra. Para Oliveira, esses dois elementos imprimiram novo vetor de dinamismo para as cidades-gêmeas da fronteira aqui analisadas.

Verificou-se em Oliveira (2008) que:

O crescimento econômico e demográfico de Santa Cruz de la Sierra, movidos pelos recursos do Banco Mundial, fez com que a Bolívia passasse a requerer uma quantidade de mercadorias sem precedentes. Essas mercadorias possuíam duas frentes de entrada no país: do Chile (produtos chilenos e outros importados pelo Porto de Arica) e do Brasil, via fronteira em questão. Mais ainda: permitiu que os produtos bolivianos de exportação, sobretudo soja, dos arredores de Santa Cruz, fossem transportados pela Rodovia até o Porto de Santos. Em todo sentido, foi se fortalecendo um Corredor entre São Paulo e Santa Cruz, onde Corumbá e Puerto Quijarro e Puerto Suárez passaram a desempenhar papel de destaque. Este destaque deve-se à condição de transbordo de mercadoria, de uma ponta-a-outra do Corredor. Por efeito, alargou os horizontes dos fluxos de mercadorias em todos os quadrantes (a mercadoria brasileira de exportação passou a ser de reexportação); novos fluxos migratórios direcionaram-se para a região, especialmente para o lado da Bolívia, fazendo crescer o volume populacional; estimulou, por sua vez, a conexão do território em redes técnicas, sejam formais, funcionais ou extralegais (OLIVEIRA, 2008, p. 246 e 247) ${ }^{15}$.

Desta forma, entende-se que a inserção do departamento de Santa Cruz no circuito espacial de produção de commodities e na circulação de bens e serviços diversos possibilitou a recuperação da dinâmica comercial nas cidades-gêmeas da fronteira. A atividade atacadista gerida por famílias corumbaenses, na sua maioria de origem árabe, veio a suprir a demanda por produtos alimentícios, vestuário e calçados, enquanto que do lado boliviano, outras famílias capitalizadas pelo comércio de fronteira se especializam

\footnotetext{
${ }^{15}$ OLIVEIRA, T.C.M. Condiç̃̃es de conurbação internacional (o caso de Corumbá-Puerto Quijarro-Puerto Suárez). IN: OSÓRIO, A. C. N.; PEREIRA, J.H.V. e OLIVEIRA, T.C.M. (orgs.). América Platina: educação, integração e desenvolvimento territorial: textos escolhidos. Vol. I. Campo Grande, MS.: Editora UFMS, 2008, p. 233-254.
} 
em produtos importados de origem americana, chilena, entre outros e, posteriormente, se instalam nas zonas francas de Puerto Suarez e Puerto Aguirre.

O segundo período tem como marco a nacionalização do gás natural boliviano. Segundo Gray Molina (2006, p.63) ${ }^{16}$, inicia-se no ano de 2006 o novo ciclo de participação do Estado boliviano na economia, cujos resultados impactam positivamente na renda e no consumo das famílias bolivianas. Conforme as expectativas do Programa das Nações Unidas para o Desenvolvimento (PNUD), elaboradas por Gray Molina (2006, p.64), o desafio principal do modelo boliviano de crescimento econômico é deixar de ser de "base estrecha", ancorado na mineração e exploração de gás, para um modelo de "base ancha", com diversificação dos setores e ampliação da base produtiva para todo o território nacional, integrando a parte oriental à parte ocidental.

A população indígena do país passou a ter acesso ao mercado de consumo de bens duráveis, uma "enxurrada" de produtos de procedência chinesa invade as áreas urbanas da Bolívia, o que também estimulou e criou novas áreas de produção para atender a forte demanda, caso de El Alto distrito industrial de La Paz especializado no setor têxtil e de confecção.

Essa demanda reprimida da população indígena se apropria de produtos "piratas", ou seja, produtos de baixo custo e com tecnologia (imitação do original) de última geração (TASSI, et al, 2013, p.77) ${ }^{17}$. Mas, para que esses produtos com tais especificações chegassem ao mercado boliviano organizou-se uma rede de cooperação de pequenos comerciantes que deram início à importação direta da China. Segundo Tassi et al (2013) as importações da Bolívia de produtos chineses nos últimos seis anos se multiplicaram por dez. No geral, são produtos de consumo de massa ou bens que podem ser revendidos no comércio popular (TASSI et al, 2013, p.77).

Sobretudo, ainda, a cultura andina prioriza a organização econômica do trabalho familiar não remunerado e a habilidade feminina com o comércio de vestuário (FAGALDE, 2004, p. 19), sendo assim, observa-se inclusive que a expansão do comércio

\footnotetext{
16 GRAY MOLINA, G. La economia boliviana “mas allá del gas”. Revista America Latina hoy, 43. Ediciones Universidad de Salamanca, 2006, p.63-85.

17 TASSI, N.; MEDEIROS, C.; RODRÍGUEZ-CARMONA, A.; FERRUFINO, G. Hacer plata sin plata: El desborde de los comerciantes populares en Bolívia. La Paz: Fundación PIEB, 2013.
} 
para todas as partes da Bolívia ocorre articulada às redes comerciais e produtivas de familiares chineses e bolivianos, cuja mão de obra boliviana é predominante feminina.

Em termos gerais, para dar conta do problema da pesquisa que trata do trabalho feminino na fronteira internacional, pretende-se nesse capítulo discorrer sobre a constituição do conceito de fronteira que tem como marco teórico a formação dos Estados Modernos, e traz a seguir o debate teórico da Geografia Política para a compreensão dos conflitos e contradições existentes nos espaços fronteiriços.

\subsection{Fronteiras: algumas definições e discussões geográficas}

A contribuição teórica de Friedrich Ratzel sobre a fronteira abrange as suas principais obras, tais como: “Antropogeografia", de 1882, e "Geografia Política", de 1897. Para entender a fronteira de Ratzel é necessário considerar o contexto vivido pelo autor, que segundo Moraes (2005, p. 67), se passou nas primeiras décadas de constituição do Estado nacional alemão e cujos desígnios eram de processo de unificação da Alemanha. Fatos que influenciaram os estudos da geografia política sobre a relação Estado e território tanto naquele país como nos demais da Europa da época (COSTA, 1997, p. 22).

Pela perspectiva ratzeliana o Estado é um “organismo vivo" e, portanto, está sempre em movimento, e assim como os seres vivos, tenderia a se comportar de acordo com as leis que regem as espécies terrestres, isto é, nasce, avança, recua, estabelece relações, declina. Tal analogia com o "organismo" diz respeito as condições naturais do solo, tais como relevo e a circulação marítima ou fluvial podem "favorecer ou emperrar o desenvolvimento dos Estados" (COSTA, 1992, p. 33).

Segundo Costa (1992, p. 34), a ideia de Ratzel sobre o solo e seus condicionantes físicos não se trata de um determinismo estreito, mas da capacidade do Estado de potencializar o uso desses recursos. Portanto, o caráter político do Estado é geográfico, dotado de um “organismo espiritual e moral”, cuja função é articular o território e o povo e manter a "unidade nacional-territorial comandada por um único poder central" (COSTA, 1992, p. 34). 
Sendo assim, a origem da fronteira para Ratzel reside no movimento, conforme descreve Martin (1992):

(...) é próprio de cada "ser vivo", e não implica uma zona de paragem duradoura, mas pelo contrário, uma paragem momentânea frente à falta de condições vitais necessárias à continuação do movimento ou então, frente à resistência de outro movimento no sentido oposto. A fronteira poderá avançar se as condições vitais o favorecerem nesse sentido ou se o movimento no sentido contrário enfraquecer. Inversamente poderá recuar se perder vitalidade ou se a força oposta se tornar mais poderosa (MARTIN, 1992, p. 15 e 16).

A organicidade do Estado territorial de Ratzel se estabelece pela força do desenvolvimento desigual das regiões, bem como, pelo sistema centro-periferia no interior do sistema, o centro se referindo ao "centro do poder", fenômeno mantido pela estrutura de circulação (COSTA, 1992, p.35). A fronteira representa a periferia desse sistema, é um órgão periférico do Estado subordinada à capital - centro do poder político (RAFFESTIN,1993, p.164). Assume duas formas territoriais: fronteiras como zonas (cidades) e as fronteiras como linhas (divisa) e faz parte dos limites do organismo do Estado.

A fronteira para Ratzel nunca teria autonomia de existência, pois ela deriva da matriz território, povo, região e Estado. Desta forma, entende que a questão da fronteira é uma questão territorial, seu conteúdo é político e sua finalidade é orientar os Estados na construção de seus territórios. Ainda, em razão da necessidade de compreender os movimentos que ocorrem em cada região do território nacional, Ratzel definiu três tipologias das fronteiras, são elas: as Fronteiras Políticas; as Fronteiras Naturais e as Fronteiras Artificiais (CATAIA, 2008, p.16).

As fronteiras políticas estão subdividas em simples, dupla, fechada, descontínua, deficiente e elástica. Nos dias de hoje, o debate sobre as fronteiras simples quase não existe, no caso do Brasil essa questão fronteiriça está restrita às águas territoriais. A fronteira fechada é formada pelos movimentos centrífugos, se apresenta como um subestado em relação ao todo Estado-territorial. Já a fronteira descontínua está relacionada com o distanciamento do centro do poder a exemplo do governo Inglês que mantém território (Ilhas Malvinas) em águas argentinas (CATAIA, 2008, p. 12).

Fronteiras deficientes são aquelas que sofrem novas demarcações por conta de conflitos. As fronteiras elásticas ocorrem em razão do desenvolvimento tecnológico, que a cada momento aumenta a precisão e tende a desaparecer a fronteira como "zona" para 
dar lugar à fronteira "linha". Os marcos físicos passam a ser substituídos pelos marcos matemáticos, implicando em novas plásticas territoriais (CATAIA, 2008, p. 13).

E as fronteiras naturais, segundo Cataia (2008, p. 13), são metáforas, porque a escolha de um marco é sempre uma escolha política, seja um rio ou uma montanha ou um grupo étnico. Já a fronteira demarcada é uma fronteira artificial para Ratzel, como não há marco físico é delimitada por acordo entre os Estados.

Quanto as políticas territoriais, entende-se como elementos constitutivos de poder, representam o exercício do domínio do Estado sobre o povo, a região e a fronteira. Para Ratzel, as políticas territoriais deveriam ser aquelas voltadas para o espaço nacional, eliminando qualquer elemento que dispersasse a política de unificação territorial, qualquer tipo de "força centrífuga". Por isso, valoriza aquela com objetivo de "colonização" em detrimento daquela outra de "conquista". E entende que o processo "valorização territorial” é de longo prazo, implica em integração econômica e política e delimitação de fronteiras (COSTA, 1992, p. 37). Ratzel afirma que, quando a "sociedade se organiza para defender o território, transforma-se em Estado" (MORAES, 2005, p.70).

Desta forma, segundo Moraes (2005, p. 70) a evolução desse organismo obrigaria aumentar o território e ocupar novas áreas, o contrário, se perdesse território significaria a decadência de uma sociedade. Mediante analogia ao evolucionismo de Darwin e a teoria da população de Malthus, elabora o conceito de "espaço vital", posteriormente incorporado nos discursos de geopolítica por Karl Haushofer que por sua vez, inflama o debate acadêmico entre os teóricos franceses e alemães.

No entanto, Costa (1992, p. 41; 1997, p. 23) menciona que apesar do esforço teórico de Ratzel de insistir nas políticas territoriais dos Estados destinadas a manter a coesão interna, há uma tendência do pensamento ratzeliano sobre o desenvolvimento político das nações pela via da ampliação dos espaços dominantes ou de controle populacional. E verifica-se que a partir de então, os estudos e teorias de geografia política sobre o Estado passaram a ter abordagens expansionistas, com conteúdo imperialistas ou belicistas, período que vai desde as duas grandes guerras mundiais até a "Guerra Fria".

A noção de fronteira linear de Ratzel é abrandada pela tese do pensamento liberal anglo-saxônico que vê na linha abstrata, invisível, um limite que ao mesmo tempo é suficiente para distinguir as responsabilidades jurídicas e político-administrativas, mas 
não impede a livre circulação de pessoas, mercadorias, capitais e informações. Exemplo: a linha que separa o Canadá dos Estados Unidos (MARTIN, 1992, p. 45).

Martin (1992), por sua vez, inicia sua abordagem sobre fronteira na natureza e associa à área de difusão de espécies vegetais e animais, assim como, os grupos humanos de características étnicas, linguística, políticas entre outras que se originam em tudo que tem movimento, e num determinado tempo se esbarram em condições adversas e os obriga a parar. Com essa analogia do mundo orgânico de Ratzel, Martin (1992, p. 16) compreende que a "determinação precisa da fronteira só pode ocorrer num lapso limitado de tempo ou então quando não nos apercebemos do movimento". Desta forma, conclui que em termos de gradação da fronteira a natureza apresenta de forma mais clara os fenômenos do que a história.

Outros clássicos sobre a fronteira são as obras de Jacques Ancel, "Geopolitique", de 1936, e "Geografia das Fronteiras", de 1938. Jacques Ancel discípulo de Vidal de La Blache enriquece o debate teórico sobre a fronteira, segundo Martin (1992, p. 44), ao refutar os conceitos ratzeliano de "fronteira linear", por ser uma ilusão cartográfica provocada pelos riscos observados nos mapas, e a "fronteira natural", uma ilusão causada pela paisagem, recupera o princípio vidaliano do "espírito de fronteira" herdado da Revolução Francesa da "inviolabilidade das fronteiras", condição jurídica internacional para a manutenção da paz.

Com base nessa crítica, Martin (1992, p. 40) enfatiza que "todas as fronteiras são construções humanas, na medida em que são os grupos humanos que atribuem a esse ou aquele acidente geográfico a condição de divisão entre um espaço conquistado e outro não". No lugar da "fronteira natural", Ancel adota a "fronteira física", de acordo com Vidal de La Blache, esse tipo de fronteira é para ser superado. De fato, afirma Cataia (2008, p. 15), as barreiras físicas foram sendo substituídas pelas políticas erigidas pelos homens.

A geografia humana de Vidal de La Blache nasceu sob a luz da crítica à geografia política ratzeliana e sua principal contribuição ao pensamento geográfico foi a introdução da História no conteúdo da Geografia. La Blache ampliou a discussão da geografia política quando afastou a politização do território e a substituiu pela relação homem, natureza e espaço (MORAES, 2005, p. 78 e 79). 
Para Moraes (2005, p. 78), a geografia política lablachiana só é compreensível se considerada a particularidade do desenvolvimento histórico vivido pela França, da conjuntura da Terceira República e o antagonismo com a Alemanha. O discurso liberal pautado na perspectiva da natureza passou a ser visto como possibilidade para a ação humana. Lucien Febvre denominou a corrente vidalina de "possibilismo". Jacques Ancel contrapôs o conceito de "gênero de vida", de La Blache, ao conceito de "posição", dos alemães inspirados em Ratzel, a fim de reivindicar a Alsácia-Lorena tomada pela guerra com a Alemanha (COSTA, 1992, 103).

O conceito de "espírito de fronteira" de La Blache trata de manifestação ligada ao gênero de vida dos habitantes das zonas fronteiriças. Refere-se a um conjunto de técnicas e costumes, construído e passado socialmente, que expressa uma relação entre a população e os recursos construídos historicamente pelas sociedades (MORAES, 2005, p. 81). De acordo com Costa (1992, p.154), Haushofer interpreta o “espírito" como apenas a manifestação da língua alemã e dos efeitos da propaganda pangermanista.

Para Haushofer, a situação alemã leva-o também ao conceito de "fronteiras vivas" ou "móveis", autênticos "organismos vivos". Para ele os povos da Europa Central são "povos de fronteira", pois possuem o "instinto geopolítico da fronteira". Ele considera que o rigor jurídico nem sempre é capaz de captar esse "espírito" que se acha enraizado no povo, ou de dar conta do caráter intrinsecamente dinâmico das fronteiras (COSTA, 1992, p. 134).

A fronteira como "uma isóbara política que fixa, por algum tempo, o equilíbrio entre duas pressões", é o conceito mais polêmico de Ancel, embora muito criticado, ainda é utilizado nos dias atuais para resolver os problemas de conflitos fronteiriços. Como observa Cataia (2008, p. 14), é necessário tomar cuidado para "não matematizar as relações entre os campos de forças, que são os territórios nas suas várias compartimentações e escalas".

Ancel e Gottmann, apesar de criticarem a geopolítica imperialista, revelaram em seus estudos conteúdo com influência mecanicista-naturalista (não expansionista), que estabelece nexos causais rígidos entre as fronteiras e o relevo, o clima, etc. Ou a situação do Estado frente aos recursos naturais, revelando uma tendência de despolitização. Outros 
geopolíticos também reproduziram esse conteúdo, como o sueco R. Kjellén, o ingês $\mathrm{H}$. Machinder e os norte-americanos A. Mahan e N. Spykman (COSTA, 1997, p. 23).

Camille Vallaux ${ }^{18}$, na vertente dialética, segundo Martin, propôs a relação de fronteira "viva" e "morta", distinta pela densidade populacional e pelas relações de intercâmbio entre as duas populações limítrofes. Outras designações são comuns, como a fronteira física "dura" e "mole" ou "quente" e "fria" para a fronteira de caráter hostil ou fraterno da relação entre os povos vizinhos (MARTIN, 1992, p. 57).

As fronteiras foram sendo classificadas, ao longo do tempo, por aspectos formais, por conteúdos, por tipos de Estado, por tipo de território, bem como, por coexistência no espaço ou por sua evolução no tempo (MARTIN, 1992, p. 55).

De acordo com Costa,

\begin{abstract}
Pela sua natureza complexa, as fronteiras constituiriam antes de tudo uma "zona viva", sejam elas "naturais" (quando se identificam com um dos elementos físicos), ou "artificiais" (linhas formais). Sob o ponto de vista da política dos Estados, toda fronteira é uma demarcação política, portanto, longe de ser considerada como "natural", mesmo que referenciada a um traço físico dos territórios em questão. Sendo um campo de forças e, em muitos casos, de disputa, o seu estabelecimento sempre envolverá negociações ou conflitos entre os Estados envolvidos (COSTA, 1992, p. 53).
\end{abstract}

A seguir, tendo como a base as categorias de análise do espaço de Santos é possível pensar a nova dinâmica territorial da fronteira entre Brasil e Bolívia. Observa-se que a fronteira é entendida para 'além da linha e limite', ou seja, é pensada a partir das relações transfronteiriças e determinada pelo movimento produzido no território.

\title{
1.1.1 Categoria espacial para análise do "espaço transfronteiriço": o território
}

De acordo com Santos e Silveira (2011, p.19 a 21), o conceito de território se divide em dois sentidos. Um mais restrito, se refere ao conceito de território político que pressupõe a existência de um Estado-Nação, e outro, atrelado ao conceito de dimensão econômica, é conhecido como território usado, categoria sistematicamente analisada pela

\footnotetext{
${ }^{18}$ Ver Wanderley da Costa, 1992, p. 29. Obra do francês Camille Vallaux, O solo e o Estado de 1910.
} 
pesquisa empírica sobre a constituição de objetos técnicos (infraestruturas) que formam um 'sistema de engenharia' 19 .

A categoria território usado por Santos (2011, p. 20 e 21), considerada pelo autor como sendo sinônimo de espaço geográfico e definida como um conjunto indissociável de sistemas de objetos e sistemas de ações ${ }^{20}$, é o objeto social da análise geográfica. Em tempos de 'globalização', a expressão contemporânea do espaço geográfico como 'meio técnico-científico-informacional' é que comanda o desenvolvimento do período atual, dando novos significados à "divisão territorial do trabalho que cria uma hierarquia entre lugares e redefine, a cada momento, a capacidade de agir das pessoas, das firmas e das instituições" (SANTOS, 2011, p. 20 e 21).

Segundo Milton Santos, estudos sobre o 'uso do território' devem levar em consideração as contradições do nosso tempo, como os conflitos entre o 'espaço local' "território de todos" e o 'espaço global' - "território transnacionalizado", que atende aos interesses de alguns. Além disso, faz crítica à noção de 'redes' e diz ser inadequada para as análises geográficas, pois fortalece o poder do mercado mundial em detrimento ao Estado territorial (SANTOS, 2005, p.259).

Desta forma, Santos (2005, p.256) retoma o conceito de 'espaço banal', de Francois Perroux, a fim de entender as contradições do espaço a partir das análises das escalas da técnica e da política. Sobretudo, Santos (2006, p.283) avança quanto ao entendimento de 'espaço banal', que para ele está além do espaço econômico ou das empresas, ao dizer que o espaço é de todas as pessoas, de todas as empresas e instituições capazes de operacionalizar um sistema de objetos por um sistema de ações.

As hipóteses dos 'aconteceres solidários' possibilitam aos lugares contíguos e em redes ser simultaneamente diferentes e divergentes, onde o acontecer homólogo e/ou complementar regido pelas técnicas exerce no lugar uma força centrípeta, já no acontecer hierárquico a primazia das normas como poder político atua como força centrífuga

\footnotetext{
${ }^{19}$ Compreender os sistemas de engenharia hoje é fundamental, pois em nome da 'competitividade' estimulam a presença de capitais fixos e especulativos em determinadas regiões que aumentam tanto a fluidez, com menos fricções e rugosidades quanto à fixidez de objetos grandes e micro-objetos (eletrônica e informática) no território (SANTOS, 2011, p.102).

20 SANTOS, M. Técnica, espaço, tempo: globalização e meio técnico-científico informacional. São Paulo: Editora Hucitec, 1994.
} 
(SANTOS, 2005, p.257). O novo recorte espacial e sua funcionalidade supõem uma nova realidade no território, as 'verticalidades' e as 'horizontalidades'.

De acordo com os comentários de Maria Adélia Aparecida de Souza ao texto "O retorno do território", de Santos (2005, p.254), as 'verticalidades' são produzidas pelo período técnico-científico-informacional que mantém a "população esparsa de objetos técnicos" a serviço do funcionamento da ordem global da sociedade e da economia. Já as horizontalidades são estabelecidas pela ordem local e pela "população contígua de objetos, reunidos pelo território e, como território, regidos pela interação, pela contiguidade".

Segundo Maria Adélia Aparecida de Souza "o uso do território se dá pela dinâmica do lugar" e faz do 'lugar' uma categoria de análise concreta, pois sofre os impactos do mundo mediante a 'fluidez virtual' dos 'objetos técnicos' e se torna real pela fluidez das "ações humanas que são cada vez mais ações informadas e normatizadas" (SANTOS, 2005, p.253).

$\mathrm{Na}$ sequência, apresenta-se o processo histórico de ocupação da fronteira internacional do Brasil. É importante dizer que essa análise descritiva trata de várias fases de povoamentos e demarcações de limites, até chegar aos tempos atuais, e à denominação de fronteira "informacional", considerando o período técnico-científico-informacional que passa a regular o locus da pesquisa.

\subsection{Os períodos da formação socioeconômica da fronteira oeste brasileira}

Este Capítulo tem como propósito, a partir da teoria do espaço de Santos (2006, p.146 e 147), fazer um ensaio teórico-metodológico sobre o "evento", enquanto uma categoria de análise, para compreender a formação socioeconômica da fronteira oeste brasileira. Com essa teoria se inicia a discussão de "uma teoria do evento" mediante uma "teoria da ação", que implicou em diferenciar e caracterizar os "momentos" do processo de povoamento, a fim de perceber "o movimento da sociedade que comanda, através do uso diversificado do trabalho e da informação", este espaço de fronteira. 
Para amparar este Capítulo foram selecionadas algumas obras da geografia política e de geopolítica para tratar dos conceitos de fronteira linha e fronteira faixa. Além disso, acrescentou-se à descrição da periodização histórica algumas pesquisas de doutorado, mestrado e artigos acadêmicos, que no geral abordam os vários "usos do território" (Santos, 2011) de fronteira. Em seguida, buscou-se relacionar esses períodos históricos com a dinâmica populacional. Por fim, foi necessário incorporar algumas variáveis macroeconômicas, como taxa de câmbio, nível de salários e preços dos produtos de commodities na análise dos vetores organizativos deste espaço de fronteira.

Os "momentos" do processo de povoamento da fronteira oeste brasileira foram elaborados com base nas principais obras de pensadores da geopolítica brasileira, com destaque o livro "Curso de Geopolítica Geral e do Brasil" ${ }^{21}$ de Everardo Backheuser e a grandiosa obra "Projeção Continental do Brasil" de Mário Travassos. Tais referências possibilitaram compreender o pensamento político da época e, portanto, tratou-se de descrever a formação territorial do país e a consolidação das fronteiras brasileiras a partir da perspectiva geopolítica de Backheuser, que definiu as três fases históricas do processo de constituição do Estado brasileiro.

A primeira fase é a colonial, marcado pelo Tratado de Tordesilhas, de 1494; seguido pelo Tratado de Madrid, de 1750; e, por último, o Tratado de Santo Ildefonso, de 1777. A segunda é a fase republicana com o Tratado de Petrópolis de 1903. A terceira trata-se da fronteira "vivificada" ou planificada.

Em termos gerais, buscou-se a partir da análise descritiva a respeito da demarcação de limites da fronteira oeste do Brasil compreender os momentos que retratam o processo de formação socioeconômico dessa parte do território nacional. Sobretudo, essa abordagem econômica sobre a constituição da fronteira oeste do país evidenciou a importância nos dias atuais do comércio transfronteiriço das cidades-gêmeas na nova divisão territorial do trabalho.

\footnotetext{
${ }^{21}$ BACKHEUSER, E. Curso de Geopolítica Geral e do Brasil. Rio de Janeiro: Biblioteca do Exército, vols. 178179, 1952.
} 


\subsubsection{A fronteira colonial e a importância da atividade comercial para delimitação da linha de fronteira entre Brasil e Bolívia.}

Segundo Backheuser (1952, p.136) nesta primeira fase histórica, a fronteira linha chega ao território latino-americano antes de ter passado pela fronteira-zona, pela fronteira-vazio e ecúmeno. Portanto, caracteriza-se como fronteira colonial ou ante fronteira, ou seja, a fronteira antes de ser.

Esse fato acontece durante o período moderno: as fronteiras coloniais evoluem para a fronteira faixa; já na Eurásia Ocidental ocorre o inverso, lembrando que a fronteira entre os países do Velho Mundo (que exclui a África e parte da Ásia) caracterizou-se como histórica, cujo processo de evolução foi lento e, portanto, as metamorfoses foram imperceptíveis (BACKHEUSER, 1952, p.137).

Dentre os inconvenientes proporcionados pelas fronteiras linhas em terras totalmente desconhecidas estão os problemas diplomáticos. Backheuser (1952, p.135) cita alguns desses exemplos entre Brasil e Argentina, em razão do território de Palmas (Missões), e outro com a França, em relação ao Amapá. O motivo desse desentendimento teve como propósito a escolha dos rios que seriam estabelecidos nos tratados, no entanto, o maior impasse veio da dificuldade dos diplomatas em demarcar os acidentes geográficos e os antropogeográficos.

Desta forma, entende Backheuser, a partir dos conceitos ratzelianos, que a faixa de fronteira é a ideal e a linha é apenas uma abstração teórica (BACKHEUSER, 1952, p.138). Sob a hipótese ratzeliana de que "a fixação de uma fronteira é um ato de vontade ou de força", Backheuser (1952, p. 144; 147; 148; 150) revela o princípio da instabilidade (equilíbrio em trânsito) das fronteiras que são "determinadas pelas forças das armas ou das circunstâncias", em especial menciona as linhas limítrofes do Brasil que por terem sido delimitadas pelos meridianos de Tordesilhas ${ }^{22}$, que supunham-se fixos, não sofreram de imutabilidade.

\footnotetext{
${ }^{22}$ Conforme observações de Backheuser (1952, p.201): "Essa célebre linha nunca foi contudo devidamente respeitada nem por portugueses nem por espanhóis. Era difícil aliás obedecer a ela na época. A astronomia e a relojoaria ainda ofereciam pouca segurança para o "transporte da hora" de sorte que, de inteira boa fé, inúmeros erros seriam cometidos ao se desejar saber a quantos graus (ou horas) jazia tal ou qual ponto em relação a determinado meridiano europeu. Aos enganos de boa fé, por ignorância ou impossibilidade científica, adicionam-se outros, oriundos da malícia, da tendenciosidade no desenho das cartas, "puxando" cada qual os acidentes geográficos, para a direita ou para a esquerda, conforme as conveniências patrióticas (...)" (BACKHEUSER, 1952, p.201).
} 
Considerando o avanço dos bandeirantes para além da linha tordesilhana, em 1750 foi acordado o Tratado de Madrid, com importante participação do brasileiro Alexandre de Gusmão. O brasileiro incorporou ao conceito de fronteira a posse das terras determinada pelo princípio do $u t i$ possidetis ${ }^{23}$ e os acidentes geográficos como limites naturais. Esse tratado inovou o significado de fronteira com "o princípio superior da posse baseado na capacidade para o domínio eficaz e povoamento effectivo das novas regiões" (CORRÊA FILHO, 1925, p.59) ${ }^{24}$.

Com a guerra entre Portugal e Espanha em 1762, houve nova investida dos espanhóis às terras portuguesas no sul do Brasil, só retomadas parcialmente em 1777 pelo Tratado de Santo Ildefonso. Esse Tratado encerra o período colonial sobre a demarcação de fronteiras, que por sorte não altera as fronteiras do lado oeste brasileiro (BACKHEUSER, 1952, p.219; 222).

Em meio ao litígio das coroas portuguesas e espanholas, as províncias ibéricas do Brasil trataram de ocupar a fronteira oeste desbravadas pelos bandeirantes com atividades de mineração, pecuária e culturas extrativistas como a borracha e a erva-mate via demarcação das fronteiras terrestre e fluvial.

A fundação de Corumbá25, em 1778, foi uma das políticas de ocupação da margem direita do rio Paraguai, importante na navegação internacional com saída para o Atlântico (IBGE, Atlas do município, 1953, p.139). Salienta-se que a política de defesa do território nacional tinha como base a navegação pelo rio Paraguai, na época importante via de acesso às minas de ouro de Cuiabá e escoamento de mercadorias das regiões originárias tanto do norte do estado de Mato Grosso como do sul, como borracha, charque, ervamate, ipecacuanha.

Segundo Corrêa (1980, p.53), a navegação comercial pela Bacia do Prata foi parte de um projeto do Império brasileiro de manutenção da integridade territorial que incluía

\footnotetext{
23 “do princípio do uti possidetis, regra de direito privado romano aplicado ao direito internacional público, tem sido o permanente orientador da nossa política territorial quando em conflito com os interesse dos vizinhos" (BACKHEUSER, 1952, p.216 e 217).

${ }^{24}$ Citação de Euclydes da Cunha, apud CORREA FILHO, V. As raias de Matto Grosso. São Paulo: Secção de obras "Estado de São Paulo", 1925. V. III, Fronteira Meridional.

${ }^{25} \mathrm{O}$ arraial de "Nossa Senhora da Conceição de Albuquerque" foi a primeira denominação de Corumbá que por um longo período foi mantido como um posto militar, foi elevada à categoria de vila em 1862 e após a Guerra do Paraguai, em 1874, à categoria de cidade (IBGE, 1953, p.142).
} 
a Província de Mato Grosso à unidade imperial, evitando as tendências separatistas em especial dessa área de fronteira, entre as repúblicas hispânicas ${ }^{26}$.

Em 1856 foi estabelecido o acordo entre os países de livre navegação pelo rio Paraguai e a partir de 1867 começam a chegar os primeiros comerciantes estrangeiros (CAMPESTRINI, 2011; CORREA, V.B., 1985, p.28). O domínio do capital nas mãos de comerciantes estrangeiros do comércio de importação e exportação e da pujança do mercado da borracha ${ }^{27}$ e da erva-mate, tornou a navegação da Bacia do Prata um elemento estratégico do Governo Imperial brasileiro que estendeu sua influência política e econômica na região do $\operatorname{Prata}^{28}$ (CORRÊA, 1980, p.53).

\subsubsection{A fronteira oeste brasileira na fase republicana e a "satelização" da Bolívia.}

Para Backheuser (1952, p. 235) a fase republicana deu fim aos territórios litigiosos de raízes coloniais que molestavam o organismo nacional e retomou as demarcações interrompidas a partir de novos contextos com bases diplomáticas e sob a liderança de Barão do Rio Branco.

É importante dizer que a atuação do Barão do Rio Branco, no período de 1902 a 1912, quanto à demarcação dos limites da fronteira brasileira marcou também o período do deslocamento do eixo diplomático brasileiro de Londres para Washington (REIS, 1994, p. 22; BUENO, 1992, apud SPRANDEL, 2005, p.158). Esse estreitamento das relações diplomáticas com os Estados Unidos deu ao Brasil maior capacidade para definir suas fronteiras com os demais países vizinhos (SPRANDEL, 2005, p.158).

O acordo de limites entre Brasil e Bolívia ${ }^{29}$ foi assinado dois anos após as primeiras negociações, em 1867 na cidade de La Paz. Teve como base o princípio do

\footnotetext{
${ }^{26}$ Conforme observa HOBSBAWM, E.J. Nações e nacionalismo desde 1780: programa, mito e realidade. Tradução Maria Celia Paoli, Anna Maria Quirino. 6a reimpressão. Rio de Janeiro: Paz e Terra, 2011. “o desenvolvimento econômico nos séculos XVI e XVIII foi feito com base em Estados territoriais, cada um dos quais tendia a perseguir políticas mercantilistas como um todo unificado" (HOBSBAWM, 2011, p.37). ${ }^{27}$ De acordo com os levantamentos de Corrêa (1980, p.74 e 75), a exportação da borracha via Bacia do Prata teve impulso a partir de 1890 e se manteve até 1914.

${ }^{28}$ A região do Prata, principalmente as cidades de Buenos Aires e Montevidéu, concentrava a atividade comercial vinculada ao capitalismo financeiro internacional (CORRÊA, 1980, p. 54).

${ }^{29}$ Segundo consta na obra de Moreira (1913, p. 141 e 142) a parte relativa aos limites está redigida do seguinte modo:“A fronteira entre Brasil e a Bolívia partirá do rio Paraguay, na latitude de $20^{\circ}, 10^{\prime}$, onde
} 
Direito Internacional “uti possidetis". No entanto, a demarcação não pôde prosseguir em razão dos protestos do governo peruano que alegou perda eventual de território motivada por esse acordo (MOREIRA, 1913, p.140 e 141).

E, além disso, a exploração da borracha no Acre acrescentou às questões de limites entre Brasil e Bolívia uma área de litígio, sendo rompida somente em 1903 com o Tratado de Petrópolis, que definiu os limites entre os dois países. ${ }^{30}$

Em termos gerais, o Tratado de Petrópolis propunha a demarcação dos limites entre Brasil e Bolívia e estabeleceu a seguinte distribuição das terras, como segue a citação abaixo sobre a fronteira oeste brasileira:

(...) ao oeste de Mato Grosso do Sul, eram: $723 \mathrm{~km}^{2}$ de terras adjacentes à Baía Negra (ao sul do Forte de Coimbra); $116 \mathrm{~km}^{2}$ na lagoa Cáceres (junto a

desagua a Bahia Negra, seguirá pelo meio desta até ao seu fundo e dahi em linha recta á lagôa de Caceres, cortando-a pelo seu meio; irá dahi á lagôa Mandioré e a cortarà pelo seu meio, bem como as lagôas Guahiba e Uberaba, em tantas rectas quantas forem necessárias, de modo que fiquem do lado do Brasil as terras altas das Pedras de Amolar e da Insua. Do extremo norte da lagôa de Uberaba irà em linha recta ao extremo sul da Coxia-Grande, salvando as povoações brasileiras e bolivianas, que ficarão respectivamente do lado do Brasil e da Bolivia; do extremo sul da Coxia-Grande irà em linha recta ao morro da Bôa Vista e aos Quatro Irmãos; destes também em linha recta às nascentes do rio Verde; baixará por este rio à sua confluência com o Guaporé e pelo meio deste e do Mamoré ao Beni, onde principia o rio Madeira. Deste rio para oeste, seguirà a fronteira por uma paralela, tirada da sua margem esquerda na latitude sul de $10^{\circ}$ e $20^{\prime}$ a encontrar o rio Javary. Se o Javary tiver as suas nascentes ao norte daquela linha leste-oéste, seguirá a fronteira desde a mesma latitutde por uma recta a buscar a origem principal do dito Javary."

${ }^{30}$ O limite entre Brasil e Bolívia segundo do Tratado de Petrópolis ficou estabelecido entre as partes interessadas que a fronteira seguisse a linha abaixo mencionada: "partindo da latitude s. de $20^{\circ}, 08^{\prime}$ e $35^{\prime}$ ", em frente ao desaguadouro da Bahia Negra, no rio Paraguay, subirá por este rio até um ponto na margem direita distante 9 kilometros, em linha recta, do forte de Coimbra, continuará desse ponto na margem direita do Paraguay por uma linha geodésica que irá encontrar outro ponto a quatro quilômetros, no rumo verdadeiro de $27^{\circ}$, 1' e $22^{\prime \prime}$ n.1. do chamado marco do fim do da Bahia Negra. Dahi seguirá no mesmo rumo determinado pela comissão mixta de 1875 até $9^{\circ}$ e $2^{\prime}$ de latitude e depois para leste por este paralelo até ao arroio Conceição, que descerá até à sua bôcca na margem meridional do desaguadouro da lagôa de Caceres, também chamado do rio Tamengos. Subirá pelo desaguadouro até ao meridiano que córta o ponto do Tamarindeiro e depois para o norte pelo meridiano do Tamarindeiro até $18^{\circ}$ e $54^{\prime}$ de latitude, continuando por este paralelo para oeste até encontrar a linha recta que fórma a fronteira actual. Do ponto de intersecção do paralelo de $18^{\circ}$ e $54^{\prime}$ com a linha recta que forma a fronteira actual seguirá até $18^{\circ}$ e $14^{\text {' }}$ de latitude e por este paralelo irá encontrar a leste o desaguadouro da lagôa Mandioré, pelo qual subirá, atravessando a lagôa em linha recta até ao ponto, na linha antiga da fronteira, equidistante dos dois marcos actuaes e depois por essa linha antiga até ao marco da margem septentrional. Dahi continuará em linha recta até á latitude de $17^{\circ}$ e $49^{\prime}$ e por este paralelo até o meridiano do extremo sudeste da lagôa Gahiba. Irá á lagôa e atravessará esta em linha recta até ao ponto equidistante dos dois marcos actuaes, na linha antiga de fronteira, e depois por esta linha até á entrada do canal Pedro Segundo (rio Pando). Da entrada sul deste até á confluência do Beni e Mamoré, os limites serão os designados no artigo 2. ํ, do tratado de 1867. Da confluência do Beni e Mamoré descerá a fronteira pelo rio Madeira até á bôcca do Apunam e subirá por este á latitude de $10^{\circ}$ e $20^{\prime}$. Dahi irá pelo paralelo de $10^{\circ}$ e $20^{\prime}$ para leste ao Rapieran e subirá por este até à sua nascente encontrar a oeste o rio Iquiry, subirá por este à sua origem, de onde seguirá até à sua confluência com o rio Acre, subindo por este à sua nascente se não estiver esta em longitude mais occidental do que a de $69^{\circ}$ oeste de Greenwich. No caso figurado seguirà a fronteira pelo meridiano da nascente até ao paralelo de $11^{\circ}$ e depois para oeste por esse paralelo até à fronteira com o Perú. Se o rio Acre atravessar a longitude $69^{\circ}$ oeste de Greenwich, o álveo do rio formarà à linha até à nascente por cujo meridiano continuará até à fronteira com o Perú" (MOREIRA, 1913, p. 148 a 151). 
Corumbá); 20,3 $\mathrm{km}^{2}$ na lagoa Mandioré (na altura do porto de Dourados, na serra do Amolar); e $8,2 \mathrm{~km}^{2}$ na lagoa Gaíba (na ponta norte da serra do Amolar) ganhando a Bolívia acesso à navegação no rio Paraguai (CAMPESTRINI, 2011, p.292).

A contrapartida do tratado foi mediante a "indenização à Bolívia de 2.000 .000 de libras esterlinas, a construção da Estrada de Ferro Madeira - Mamoré e a cessão de terras brasileiras à margem direita do rio Paraguai”(CAMPESTRINI, 2011, p.291).

Segundo Backheuser (1952, p.244) a alta indenização paga à Bolívia teve como motivo a extinção do sindicato anglo-americano do continente sul-americano, que poderia num futuro próximo irradiar novas reivindicações.

Após estabelecidas as fronteiras políticas, Travassos (1947, p. 66) introduz novo debate para as questões internacionais entre Brasil e Bolívia, que trata do deslocamento do eixo dinâmico de Cochabamba para Santa Cruz, cujo propósito geopolítico seria substituir a influência da rede ferroviária platina para "a espontaneidade viatória da Amazônia”. Ressalta Travassos que:

(...) trata apenas de descolar o centro de atração da região de Cochabamba para Santa Cruz, inclusive, porque a atração exercida por Cochabamba é por assim dizer artificial, produto das facilidades de comunicações de que tem desfrutado, ao passo que Santa Cruz representa realmente o verdadeiro centro de gravidade da economia do planalto (TRAVASSOS, 1947, p.65).

A obra de Travassos, "Projeção Continental do Brasil" publicada em 1931, segundo Mello (1997, p.55), "tornou-se um marco do pensamento geopolítico brasileiro". Uma passagem do general Meira Mattos que fala da importância dessa obra: "A obra de Mário Travassos realizou um inigualável labor de pioneirismo intelectual. Abriu os horizontes da interpretação geopolítica dos fenômenos brasileiros e continentais para as elites civis e militares da época” (MATTOS, 1975, apud MELLO, 1997, p.56).

Travassos insere o território de Mato Grosso no contexto geopolítico do continente sul-americano, a partir da disputa de soberania entre Brasil e Argentina. Para Travassos o Mato Grosso "é assim, do ponto de vista de nossa política continental, verdadeira miniatura do próprio Brasil, símbolo expressivo de nossos interesses políticos no continente" (TRAVASSOS, 1947, p. 241).

Segundo Travassos (1947, p. 241), a posição geográfica do estado de Mato Grosso é importante porque é definido por duas fronteiras do Brasil, bem demarcadas pelas duas 
bacias sul-americanas, ao sul a bacia do Prata que faz limite com o Paraguai e ao norte a bacia da Amazônia com a Bolívia.

Conforme a análise de Travassos sobre as duas forças antagônicas entre o Atlântico e o Pacífico, essas duas bacias sul-americanas - Amazônia e Prata - constituem dois compartimentos diferentes, por onde se manifesta o desejo da Bolívia de acesso ao mar (TRAVASSOS, 1947, p.23 e 24).

A observação de Travassos sobre a influência de Santa Cruz de la Sierra no planalto boliviano, descreve duas direções, que sob a atração que exerce sobre Santa Cruz, uma delas levaria para o lado leste por meio do acesso terrestre de Puerto Suarez ${ }^{31}$ e outra para o lado norte pelo Madeira - Mamoré32.

A "Projeção Continental do Brasil" e a "Projeção Continental de Mato Grosso", dizia Travassos (1947, p.237 e 238), "são quase que a expressão de uma mesma série de fatos geográficos". Isso significa que, a importância de sua posição geográfica "pode definir a política continental do Brasil”

Tal espaço geográfico fez parte do processo de "satelização" da Bolívia, mediante a expansão da rede ferroviária Noroeste do Brasil que se iniciou em 1905 com o trecho Bauru - Itapura, inaugurado em 1910, e atingiu Porto Esperança em 1917, totalizando $1.273 \mathrm{~km}$ de Bauru até Porto Esperança (AZEVEDO, 1950, p.108) ${ }^{33}$.

\footnotetext{
${ }^{31}$ Para Travassos: “A atração de leste (Puerto Suarez), se se prolongasse nessa direção com a necessária eficiência, seria verdadeiro golpe nas atrações do sul, pois levaria ao Atlântico, $1.600 \mathrm{~km}$ de costa acima da foz do Prata (Santos), através de 2.576 km ou seja cerca de 700 km menos que por Buenos Aires. Para isso bastaria a construção da linha Santa Cruz de la Sierra - Puerto Suarez" (TRAVASSOS, 1947, p.103). 32 "Finalmente resta a atração do norte que se manifesta pela Madeira - Mamoré captando os transportes pelo Rio Grande, francamente navegável desde Cuatro Oyos (200 km abaixo de Santa Cruz, dos quais 100 já abertos em rodovia) e podendo ser dobrada por transportes rodoviários, quando se ligarem Portachuelo - Cuatro Oyos - Trinidad - Santana - Exaltación (centros dos mais fluorescentes) a Santa Cruz e Guajará Mirim" (TRAVASSOS,1947, p.104).

33 Segundo AZEVEDO, F. de. UM TREM CORRE PARA O OESTE. Estudo sobre a Noroeste e seu papel no sistema de viação nacional. São Paulo: Livraria Martins Editora, 1950. “Foi do Clube de Engenharia, do Rio de Janeiro, que partiu o último e mais vigoroso impulso para sua realização quando, em Outubro de 1904, "deliberou indicar ao governo" como problema nacional inadiável "o traçado de um caminho de ferro que, partindo de S.Paulo dos Agudos (ou de Baurú), transpondo o Paraná e o Urubupungá, se dirigisse a um ponto do rio Paraguai adequado a encaminhar para o Brasil o comércio do sudeste boliviano e norte paraguaio, permitindo ao mesmo tempo rápidas comunicações do litoral com Mato Grosso, independentes do percurso em território estrangeiro". Essa citação é da obra de Euclides da Cunha. A margem da história. Cap. Viação Sul-Americana, p. 139-163, 3a edição. Livraria Chardon, Porto, 1922, apud AZEVEDO, 1950, p. 108.
} 
Corrêa (1980, p. 122) menciona Sodré (1941, p. 111) sobre a importância geopolítica da ferrovia nessa zona fronteiriça de influência platina. Para Sodré:

\begin{abstract}
A Noroeste do Brasil vinha resolver um problema geográfico de primeira ordem, em relação ao Oeste: constituiria o vínculo, ainda bem tênue, é verdade, que uniria os territórios mato-grossense ao corpo do Brasil, do qual estavam divorciados, obrigados a depender da via fluvial do rio Paraguai, viável, para nós, desde a guerra contra a república do mesmo nome, mas que nos colocava na situação de aceitar a preponderância estranha das forças orientadas para a bacia platina, em lugar corresponder ao apelo das forças nacionalizadoras que atraem para a zona amazônica ou para os portos do Atlântico, no litoral paulista (SODRÉ, N.W. Oeste. Ensaio sobre a grande propriedade pastoril. Rio de Janeiro: José Olympio, 1941, p.111, apud CORREA, 1980, p. 122).
\end{abstract}

A continuação do trecho Bauru-Corumbá ocorreu com a construção do trajeto Corumbá-Santa Cruz de la Sierra ${ }^{34}$, mediante acordo do governo brasileiro assinado em 1938 que tratou do financiamento para a construção da estrada de ferro, em contrapartida ao fornecimento de petróleo andino (MENDONÇA, 1956, p.183).

A partir da criação da Petrobrás pela Lei n. 2.004, de 3 de outubro de 1953, a qual estabeleceu o monopólio estatal do petróleo, foi imposta uma nova relação do território nacional com o território boliviano; o Art. 41 permite a Petrobrás se associar a entidades destinadas à exploração de petróleo fora do território nacional (SOARES, 1972, p.253).

\title{
1.2.3 A fronteira da "vivificação" e as estratégias de planificação das faixas de fronteira entre Brasil e Bolívia.
}

De acordo com Sprandel (2005, p.182), essa é a passagem do período de demarcação de limites, enquanto ideia de expansão territorial para um outro período cuja realidade é vista pela dimensão do poder, onde o Estado se utiliza de conceitos e noções de geopolítica para elaborar e executar o planejamento sobre a ocupação das faixas de fronteiras.

\footnotetext{
${ }^{34}$ Conforme AZEVEDO, F. de. UM TREM CORRE PARA O OESTE. Estudo sobre a Noroeste e seu papel no sistema de viação nacional. São Paulo: Livraria Martins Editora, 1950. "A diretriz desse caminho de ferro que se prolonga da Corumbá a Santa Cruz, assim como os propósitos que levaram os dois países a se porem afinal de acordo para a realização do empreendimento, ligam-se, porem, tanto ao problema do petróleo boliviano quanto a ideia da transcontinental a que ela serve como uma de suas grandes seções e a que se subordinou desde as suas origens históricas. É o que revela o seu próprio traçado que conduz os trilhos diretamente para a faixa petrolífera da qual Santa Cruz, no Chaco, é o extremo ponto setentrional, e a cidade de Yacuíba, na Argentina, é o extremo meridional" (AZEVEDO, 1950, p. 316 e 317).
} 
Para Backheuser (1952, p.157), as fronteiras modernas são instáveis, portanto podem ser mortas ou vivas dos dois lados ou viva só de um lado.

A "vivificação" de que trata Backheuser (1952, p.157) diz respeito a "uma região de fricção, por meio da qual, mais dia menos dia, surgem ou se agravam os conflitos internacionais, políticos, ou de ordem fiscal e administrativa, ensejando demonstrações de força militar”.

No entanto, afirma Backheuser (1952, p.160):

Quando uma fronteira é viva de um lado e apenas esboçada ou já morta, ou de pouca atividade, do outro, o previsível resultado é processar-se, mais hoje, mais amanhã, um deslocamento no sentido do Estado de menor vitalidade, toda vez que a outra Potência esteja em situação de exibir seu poder militar, ou não esteja couraçada de escrúpulos morais (BACKHEUSER, 1952, p.260).

Sendo assim, Backheuser (1952, p.261) propõe a "vivificação" das faixas de fronteira a partir da implantação de uma política de fronteiras que valorize um "povoamento produtivo":

(...) amanhando e explorando o solo, estabelecendo núcleos industriais, convenientemente espaçados, do que tudo resultaria adequada distribuição da população. Seria necessário complementarmente lançar e intensificar vias de comunicação terrestres e fluviais, destinadas ao transporte de gente e mercadorias, bem como incrementar a navegação aérea, mesmo que não fosse comercialmente remuneradora no momento (BACKHEUSER, 1952, p.261).

Portanto, cabe ao Poder Central delimitar a largura dessa faixa e regras de aproximação, segundo Backheuser (1952, p. 263), "a fronteira é o órgão periférico do Estado", então, cabe a esse exercer seu poder sobre as múltiplas e discriminadas funções que possui uma faixa de fronteira.

Quanto à largura da faixa de fronteira brasileira, consta no Decreto n. ${ }^{\circ} 1.318$ do Brasil Império a fixação de dez léguas (aproximadamente $66 \mathrm{~km}$ ) acompanhando a linha da fronteira; já na Constituição de 1934 a largura da faixa fronteiriça eleva para 100 quilômetros; por ora, na Constituição de 1937 chega a 150 quilômetros (RODRIGUES, 1947, p. 67).

Segundo Martin (1992, p.84), no Brasil, as mais importantes políticas de "fronteiras vivas" que tiveram como objetivo principal a interiorização e povoamento com ocupação produtiva, foram: a construção da Estrada de Ferro Noroeste do Brasil, a 
rodovia Belém-Brasília com a fundação da nova capital federal; a Transamazônica; o projeto Calha Norte e a rodovia BR-364 de Porto Velho que segue até Lima no Peru.

No início da primeira crise do petróleo, meados de 1974, o governo Geisel projeta o país no continente sul-americano mediante estabelecimento de Acordo de Cooperação e Complementação Industrial assinado em Cochabamba.

Esse acordo, segundo Mello “é importante não só pelas consequências políticoeconômicas que poderá produzir nas relações entre os dois países, mas também por suas repercussões no equilíbrio de poder no sistema platino" (MELLO, 1997, p.157 e 158).

Em síntese, Mello afirma que as vantagens do Brasil com o Acordo de Cooperação e Complementação Industrial foram: a satelização da Bolívia, enfraquecimento da Argentina e saída para o Pacífico (MELLO, 1997, p. 162).

\subsubsection{O novo dinamismo da fronteira entre Brasil e Bolívia.}

Conforme observa Cataia (2001), essa última fase aborda a fronteira a partir da produção do espaço de conteúdo híbrido entre as materialidades e as ações, agora sob a perspectiva econômica, a fronteira tem uma forma-conteúdo capaz de produzir intencionalidades, ou seja, produz relações de poder.

O período informacional é uma proposta teórico-metodológica para discutir a fronteira internacional entre Brasil e Bolívia a partir do período técnico-científicoinformacional de Milton Santos. Esse período, discutido na tese defendida no ano de 2001 por Márcio Antonio Cataia sobre fronteiras internas no território nacional, permite compreender as fronteiras nacionais em tempos de globalização, bem como, revela como se dá a dinâmica da produção do espaço de fronteira.

Ao propor o debate sobre a fronteira, Cataia (2001, p. 33) menciona Raffestin (1993), que diz: "o poder surge a partir das relações, por isso seu fundamento ser “multidimensional" e o Estado não ser o monopolizador do poder". A partir da crítica à geografia política clássica, Cataia introduz à temática fronteiriça a questão da informação no território. Segundo Cataia (2001, 85 e 86): 
Informação que, diferentemente de outros períodos históricos, se autonomizou, isto é, antes do aparecimento da telegrafia, da radiotelegrafia ou do telefone eram os homens e as mercadorias que portavam a informação. Com o desenvolvimento da técnica, primeiro do cabo, depois das ondas eletromagnéticas a informação ganhou ela própria um status físico. A informação passa a ser definida a partir de impulsos elétricos que transmitem uma mensagem. Esse desenvolvimento técnico só faz reforçar a importância da análise do espaço geográfico como um híbrido entre materialidades e ações, porque as ações cada vez mais se enraízam nas materialidades para germinar num novo espaço geográfico (CATAIA, 2001, p. 85 e 86).

Cataia nos faz pensar a fronteira a partir do período técnico-científicoinformacional, essa importante periodização revela as ações e interesses da população ou dos atores responsáveis pela produção desse espaço. Portanto, para esse autor (2001, p. 121) a fronteira é uma forma-conteúdo e por ser portadora de informação produz intencionalidades.

Esse período pode ser retratado a partir do acordo binacional denominado de projeto "Gasoduto Bolívia-Brasil", cujo objetivo principal foi de atender a demanda por gás natural das indústrias situadas nas regiões industrializadas, no entanto, atrelado a esse investimento estão as intencionalidades, que como exemplo o caso estudado por Silveira (1994) na Argentina, é possível observar nessa ação tanto do Estado brasileiro quanto boliviano, o exercício da função de regulador e organizador do território garantindo a fluidez de objetos e informações aos atores hegemônicos.

E decorrente a isso, o que se percebe é que os investimentos em ferrovias e hidrovias, hoje "objetos envelhecidos pela aparição dos objetos tecnicamente mais avançados" estão, conforme enfatiza Santos (1994a), subordinados às ações hegemônicas que determinam uma hierarquia dos objetos, e desta forma, “(...) a remodelação espacial se constrói a partir de uma vontade distante e estranha, mas que se impõe à consciência dos que vão praticar essa vontade".

Conforme a observação da realidade, a existência de empreendimentos na atual fronteira oeste brasileira está vinculada à exploração de minério e ao projeto de geração de energia mediante a futura instalação de uma termelétrica nessa região de fronteiriça, que nos dizeres de Santos (1994b), aparece como "território compartido".

Parte dessa dinâmica está relacionada com o que Pfrimer e Roseira (2009) observam no espaço boliviano. Segundo esses autores, 
Essa influência pode ser notada na "Geopolítica Aplicada", implícita nos projetos geopolíticos dos anos 70 destinados a esta área [se refere ao Heartland sul-americano], como a construção da ferrovia Santa Cruz - Yacuiba, a rodovia ligando Santa Cruz a Cochabamba, a construção de uma rede elétrica e de gasodutos, além de várias refinarias. Essas transformações territoriais levaram à configuração de uma área bem articulada e de substancial importância formada pelas cidades de Santa Cruz, Cochabamba e Tarija. Esse novo arranjo territorial detém aproximadamente $60 \%$ do Produto Interno Boliviano, quase metade da população boliviana e, $98 \%$ e 99,2\% das reservas provadas de gás e petróleo na Bolívia, respectivamente (PFRIMER e ROSEIRA, 2009).

Outro aspecto da fronteira política é discutido por Lia Osório Machado. A autora chama a atenção para as mudanças das escalas geográficas que mostram os novos condicionantes da fronteira continental. De acordo com Machado (2005):

\begin{abstract}
Nas escalas global e continental há um aprofundamento de dinâmicas que desafiam os sistemas tradicionais de controle territorial dos estados nacionais, em virtude de mudanças nas condições técnica-tecnológicas no campo da produção e troca de informações e da proliferação de estratégias e planos de ação de organismos internacionais e empresas transnacionais. Deve-se destacar também a disseminação de processos que exigem tratamento bilateral ou multilateral, como a implantação e desenvolvimento de agrupamentos funcionais dos Estados Nacionais (MERCOSUL, Comunidade Andina), a integração da malha viária sul-americana, a intensificação do tráfico de armas e drogas ilícitas na Zona de Fronteira e a expansão dos movimentos migratórios e pendulares na região. Os Estados encontram-se, portanto, diante da necessidade de ajustar suas políticas públicas à 'permeabilidade' das fronteiras e, ao mesmo tempo, fomentar a articulação da Faixa de Fronteira às outras regiões do país, diante do fato dela estar situada à frente do processo de integração sul-americana. Nos âmbitos sub-nacional e local despontam sinais de insatisfação com o modelo tradicional de relações hierárquicas entre o estado/região (inferior) e o centro decisório nacional (superior), e que se expressa na faixa de fronteira pela crítica ao desconhecimento dos efeitos nestas escalas de decisões tomadas na esfera federal e ao não reconhecimento das especificidades territoriais dos municípios de fronteira (MACHADO, 2005, p.88).
\end{abstract}

Para tanto, cabe observar que o Governo Federal em conjunto com o Ministério da Integração Nacional realiza, desde novembro de 1999, o Programa de Desenvolvimento de Faixa de Fronteira - PDFF, no qual reconhece o papel estratégico da faixa de fronteira e a considera como "região de visível potencialidade para catalisar a integração sul-americana" (GADELHA e COSTA, 2005, p.30).

Tal programa abrange uma área de $15.719 \mathrm{~km}$ de fronteira, isso corresponde a $27 \%$ do território nacional. São 11 estados e 588 municípios que fazem limites com dez países e somam aproximadamente 10 milhões de habitantes (GADELHA e COSTA, 2005, p.26).

Conforme GADELHA e COSTA, foi proposta uma nova: 
sub-regionalização baseada em afinidades sociais, culturais, históricas, étnicas e de potencialidade e dinamismo econômico que sejam fortes o suficiente para otimizar iniciativas conjuntas. O resultado foi a subdivisão da faixa em 17 subregiões, agrupadas em três grandes $\operatorname{arcos}(.$.$) (Norte, Central e Sul). (...)O Arco$ Norte abrange a faixa da fronteira do estado do Amapá até o Acre. (...)O Arco Central abrange a faixa de fronteira dos estados de Rondônia, Mato Grosso e Mato Grosso do Sul. Oito sub-regiões foram identificadas, um indicador de grande diversidade nos tipos de organização territorial. A unidade do Arco deriva do caráter de transição entre a Amazônia e o Centro -Sul do país e de sua posição central no subcontinente. (...)o arco central apresenta quatro modelos de organização do sistema produtivo. Três deles ligados à produção agrícola e a criação de gado e um quarto modelo industrial-comercial ligado à agroindústria englobando redes de secagem e armazenamento de soja além de frigoríficos de carne bovina e pescado. O Arco Sul compreende a faixa de fronteira dos estados do Paraná, Santa Catarina e Rio Grande do Sul (GADELHA e COSTA, 2005, p.32, 33 e 34).

Ao que tudo indica, nasce uma nova dinâmica regional, pensada a partir da complementaridade onde os 'novos e o velhos' atores dos dois lados intensificam suas relações comerciais, produtivas e culturais. A nova organização territorial que se faz presente aproxima a região da fronteira oeste brasileira, dada pelas cidades-gêmeas Corumbá (lado brasileiro), Puerto Quijarro e Puerto Suarez (lado boliviano).

Na sequência, estão relacionadas as fases conceituais da fronteira oeste brasileira e da fronteira oriental boliviana com as suas distintas formas de povoamento e fixação.

\subsubsection{A distribuição populacional da fronteira oeste brasileira e da fronteira oriental boliviana}

A população rarefeita da fronteira oeste brasileira até o início do período republicano teve como base as fortificações militares. O contingente de militares do governo central em Mato Grosso era de cerca de 10,8\% do efetivo do exército do país, um dos mais altos, considerando que a população do estado em relação à população brasileira era de apenas 0,64\%; já a taxa de soldados por mil habitantes chegou a 13,67 no ano de 1888 (MAMIGONIAN, 1986, p.42).

Pelos acordos imperiais, o porto de Corumbá era o único habilitado a receber embarcações de todas as bandeiras, isso implicou em centralização dos fluxos comerciais e, especificamente, na concentração do poder administrativo e político da cidade nas mãos de um grupo de comerciantes de importação e exportação, que projetou a cidade de acordo com os seus interesses (CORRÊA, 1980, p.127). 
A intensidade dos fluxos comerciais acelera a urbanização da cidade de Corumbá. No ano de 1859, o presidente da Província, Joaquim Raimundo de Lamare mandou delinear as ruas, praças e demarcar lotes para os edifícios públicos em Corumbá (CAMPESTRINI, 2011, p.247). No entanto, foi a após a Guerra do Paraguai que a cidade ganha ares cosmopolita, migrantes de várias partes do mundo vem aportam seu capital na atividade de exportação e importação e deixam seu legado no conjunto arquitetônico do casario do porto.

Durante a Guerra com o Paraguai (1864 a 1870), particularmente no ano de 1865 a vila de Corumbá foi arrasada pelos soldados paraguaios. Somente em 1867 com a retomada da cidade das forças paraguaias iniciou-se "um período de surpreendente progresso, provocado (...) pela isenção quase completa de impostos (...). Esta isenção, por dez anos, fora decretada pelo governo imperial em 1869" (CAMPESTRINI, 2011, p.248).

Dentre outras medidas do governo imperial de recuperação de toda a região meridional de Mato Grosso, no pós-guerra com o Paraguai, está a restauração do município de Corumbá, em 1871 e a reinstalação da alfândega de Corumbá, em 1872, que supriu os serviços de armazenamento e arrecadação de impostos de importação e exportação, e, logo em seguida, começa a construção do Arsenal da Marinha em Ladário (CORRÊA, 1980, p.60).

Corrêa (1973, p. 17) evidencia a nova dinâmica econômica de Corumbá. Segundo esse historiador:

O governo imperial, numa tentativa de ajudar seus habitantes e incrementar o desenvolvimento da região, franqueou o porto à importação de mercadorias de todas as origens. Logo, todo o movimento comercial da Província passou a girar em torno desta atividade. Assim, Corumbá retoma, pouco a pouco, seu dinamismo como centro comercial da região, aumentando gradualmente sua população, adquirindo novos direitos como cidade e impulsionando cada vez mais sua principal atividade econômica: o comércio (CORRÊA, 1973, p.17).

O resultado dessas medidas governamentais pode ser verificado nos dados demográficos da época. Conforme o censo de $1872^{35}$ a população de Corumbá passou de 3.361 habitantes, para 12.529 habitantes no ano de 1900 .

\footnotetext{
35 “No dia 1 ㅇ de agosto de 1872, foi realizado o primeiro censo nacional, registrando, no Brasil, 10.112.061 habitantes (8.602.061 brancos e 1.510 .000 negros); e, na província de Mato Grosso: a) em Miranda 3.852 habitantes (entre eles, 142 escravos; não havia estrangeiros); b) em Corumbá - 3.361 habitantes (entre eles, 275 escravos e 647 estrangeiros; dentre estes, 226 paraguaios); c) em Santana do Paranaíba
} 


\begin{tabular}{r|r|r|r}
\hline \multicolumn{1}{r|}{$\begin{array}{r}\text { População Total } \\
\text { Corumbá }\end{array}$} & \multicolumn{2}{|c}{$\begin{array}{c}\text { Período final do Império e início do Republicano (por } \\
\text { ano) }\end{array}$} \\
\hline Santa Cruz de la Sierra & - & 1875 & 1900 \\
\hline Puerto Suarez & -6.005 & - & 3.361 \\
\hline
\end{tabular}

TABELA 1 - População total da fronteira linha (Brasil e Bolívia), referente ao final do período Imperial e início do Republicano - 1845 a 1900.

Fonte: IBGE/Evolução da população segundo os municípios; MESA, GISBERT e GISBERT. "Historia de Bolivia", 2008, p.683.

Elaboração: SOKEN, D.

É necessário dizer que a cidade de Santa Cruz de la Sierra foi incluída na tabela de população da fronteira entre Brasil e Bolívia por considerar o efeito polarização que causa nessas localidades.

Enquanto isso, no outro lado da fronteira, a exploração de prata na porção central do Altiplano boliviano aconteceu até meados do século XVIII e implicou em concentração populacional nas cidades produtoras tais como Potosí, La Paz, Cochabamba e Sucre, essa última pela importância da articulação política da elite mineira. Já a cidade de Santa Cruz de la Sierra situada na planície se especializou na produção de alimentos e supria as regiões de conflitos entre a planície e os vales (FREIRE, 2008, p.75; 78).

Observa-se que o significativo crescimento populacional de Santa Cruz de la Sierra $^{36}$, que passou no ano de 1845, de 6.005 habitantes para 18.335 habitantes em 1900, teve como marco dois conflitos de limites fronteiriço, registrados um com o Chile e outro com o Brasil. Tais movimentos ressaltam o começo da migração da população andina para a planície boliviana.

O município de Puerto Suarez ${ }^{37}$ fundado em 1875, que era habitado por 560 pessoas no ano de 1900, se originou de territórios indígenas colonizados por missões

- 3.234 habitantes (entre eles, 354 escravos e 100 estrangeiros)." Conforme consta na obra "A Guerra do Paraguai" de Joaquim Francisco de Mattos, citado por CAMPESTRINI (2011, p. 253).

${ }^{36}$ A cidade de Santa Cruz de la Sierra, fundada em 1561, teve como função principal abrigar as instalações militares espanholas no combate às invasões indígenas. (FREIRE, 2008, p.13)

37 “Foi fundada às margens da baía de Cáceres, na margem direita do rio Paraguai, em 10 de novembro 1875 por Miguel Suarez Arana, o empresário visionário que sonhava em unir a Bolívia oriental do Oceano Atlântico através dos rios Paraguai e Paraná. Neste porto fluvial foi construído um cais no ano de 1900, o que permitiu a Bolívia receber navios mercantes de várias partes da Europa e do Sul e do Leste da América e de outros continentes trazer a rica produção gomífera do departamento, que era altamente valorizada na época" (PDM/PUERTO QUIJARRO, 2006). 
jesuíticas, essas, logo foram expulsas e deu-se início à expansão de latifúndios de agricultura e pecuária (CONSORCIO BURNSIDE/PUERTO SUAREZ, 2006, p.8).

Mas, foi a partir da guerra do Chaco, entre 1932 a 1935, que o Departamento de Santa Cruz passou a ter importância no cenário nacional boliviano, se especializando na produção de alimentos durante a guerra ${ }^{38} \mathrm{e}$, posteriormente, explorando petróleo e gás. ${ }^{39}$

Segundo Pfrimer e Roseira (2009), os subsídios dados ao setor agroexportador de Santa Cruz a partir da década de 1940 inseriram sua capital no cenário internacional e atraíram novos investimentos de infraestrutura (ferrovia, estrada, energia, serviços financeiros, entre outros) para o lado oriental da Bolívia ${ }^{40}$.

De acordo com os dados históricos do município de Puerto Quijarro coletados a partir do Plano de Desenvolvimento Municipal (PDM) de 2006, é possível constatar que a construção da estrada de ferro do trecho Santa Cruz de la Sierra - Corumbá causou forte fluxo migratório para a faixa de fronteira, o que criou novo pólo de desenvolvimento na região, formado pelo eixo San Jose - Puerto Suarez.

Segundo a classificação de Souchaud (2008, p. 35) quanto ao fluxo migratório de bolivianos para Corumbá, esse primeiro período trata-se de uma categoria de migrante clássico, ou seja, é de larga duração e tem destino único, neste caso, as cidades de Corumbá e Ladário. Sendo assim, Souchaud conclui com base em sua pesquisa que a fronteira tem uma existência própria enquanto lugar de destino para essa primeira leva de migrantes.

Outro fato que intensificou o fluxo migratório na parte oriental da Bolívia, conforme consta no PDM, foi o novo "boom" da borracha do norte da Bolívia que fez

\footnotetext{
${ }^{38}$ FREIRE, E.M. Bolívia: crise de coesão territorial no coração da América do Sul”. São Paulo: FFLCH/USP, 2008 (dissertação de mestrado)

39 "O fim da guerra do Chaco (...)marca o fim da expansão da indústria mineira (...) apresentando a nova hegemonia da exploração do petróleo e gás" (FREIRE, p. 39)

${ }^{40}$ Para Pfrimer e Roseira (2009), “(...) a inversão de financiamentos em Santa Cruz não foi mera obra do acaso. Além do desenvolvimento nacional, o fator geopolítico e a influência estrangeira foram preponderantes para que Santa Cruz se tornasse pólo de atração. Após a ascensão de Hugo Banzer, em 1971 na Bolívia, sob os auspícios do regime militar brasileiro e americano, mais de $70 \%$ dos créditos concedidos pelo Banco Agrícola e a corporação de Desenvolvimento Regional foram destinados à Santa Cruz.... O governo americano ao conceder empréstimos à Bolívia condicionou a realização dos empréstimos ao requisito de que mais da metade deles fossem implementados em Santa Cruz de La Sierra. Nesse período, os americanos já tinham se decidido pelo Brasil como aliado regional, e portanto, fazia parte do interesse americano que o Brasil mantivesse sua influência em território boliviano por meio da atração de Santa Cruz à esfera política brasileira".
} 
aumentar a demanda por alimentos, isso atraiu inúmeros comerciantes brasileiros interessados em abastecer a região.

Ainda de acordo com o PDM (2006), novos centros urbanos surgiram nas décadas de 1960 e 1970 no entorno da rede ferroviária, formados pelos novos fluxos de migrantes procedentes de vários lugares da Bolívia. Mas, foi a partir da década de 1980 que proliferou nesses núcleos urbanos o comércio legal e ilegal de todos os tipos de produtos na faixa de fronteira (cidades de Puerto Suarez, Puerto Quijarro e San Mathias).

Por ora, do lado brasileiro, a cidade de Corumbá ao longo do século XX se mantém como uma das cidades mais importantes do Estado de Mato Grosso.

Foi na virada do século XIX para o XX que a unidade territorial brasileira, então denominada de 'Fronteira Oeste', em especial a província mato-grossense, lugar de grandes vazios populacionais e de difícil acesso, se torna um espaço não somente de defesa militar para fins de exploração aurífera ${ }^{41}$ como também se insere no contexto internacional de comércio de exportação e importação via navegação fluvial.

A então capital Cuiabá exercia a função de centro exportador e redistribuidor de mercadorias, onde se aglomeravam grandes comerciantes, geralmente portugueses, que junto com a aristocracia rural constituíam as principais frações da classe dominante da região.

Em meados do século XIX, com a expansão das atividades agropecuárias, a extração da erva-mate e, principalmente, com a abertura da navegação pelo rio Paraguai na parte meridional de Mato Grosso, o centro comercial de Cuiabá começou a perder importância para a cidade de Corumbá. Essa última passou a servir de entreposto comercial favorecendo o comércio de Mato Grosso com o Rio de Janeiro ao reduzir o tempo de viagem, antes realizado por tropas de mulas. Tal fato transformou Corumbá em ponto de passagem obrigatório para as exportações e importações de mercadorias de Mato Grosso.

\footnotetext{
${ }^{41}$ Côrrea \& Côrrea (1985: 28), devido as dificuldades de uma ocupação populacional mais permanente nas terras mato-grossenses, a ocupação militar fez-se necessária nesta época, fundando-se os fortes de Coimbra (1775) e Príncipe da Beira (1776), e a povoação de Corumbá (1778 - denominada então de Albuquerque), cujos objetivos eram proteger a área de exploração do ouro e os "súditos de Portugal", garantindo as relações mercantilistas da Coroa.
} 
A navegação fluvial via Bacia do Prata permitiu uma maior integração mercantil da economia mato-grossense, intensificando as relações comerciais em nível nacional e internacional. Neste período da economia de Mato Grosso - as atividades comerciais de exportações de matérias-primas, - tais como: gado em pé, erva-mate, etc, e as importações de produtos manufaturados, foram predominantes sobre o desenvolvimento das atividades produtivas, submetendo a dinâmica regional à "dependência das relações externas" $" 42$.

Conforme esclarece Oliveira (2009, p. 34), até a década de sessenta do século XX, Corumbá desfrutou de um dinamismo próprio pautado principalmente no comércio de exportação e importação, investimentos no setor industrial e pela produção da pecuária bovina. Observa-se que "durante esse período a fronteira foi, nada mais, que um marco divisório sem expressão, de comunicação reduzida e ineficiente".

Nas duas décadas seguintes a cidade entra em estagnação demográfica e o declínio econômico é inevitável, segundo Oliveira (1998, p. 46), o que de fato levou o centro comercial de Corumbá à decadência foram fatores internos e externos ligados à própria dinâmica regional da cidade. A nascente indústria alimentícia e o comércio portuário passaram a sofrer os impactos das mercadorias vindas das indústrias de São Paulo, trazidas pela ferrovia e, mais tarde, pela rodovia.

\begin{abstract}
Alguns fatores de ordem externa foram minando a resistência da capacidade industrial e regional de Corumbá: o crescimento e modernização da indústria no centro dinâmico da economia brasileira, produzindo mercadorias com preços mais baixos do que as produzidos em Corumbá; expansão e melhoria das condições de transportes fora e dentro do Estado; queda do preço dos minérios de ferro e manganês no mercado internacional; fortalecimento e dinamismo da condição regional da cidade de Campo Grande;(...) Mormente, dois fatores de ordem endógena minaram com agudez a estrutura econômica da região: a imposição geográfica dos ciclos de cheias e secas do Pantanal e a imutabilidade da estrutura produtiva agrária (OLIVEIRA, 1998. p. 46).
\end{abstract}

E mesmo com a expansão do mercado paulista a pecuária pantaneira veio à bancarrota, o crédito nas mãos de comerciantes locais obrigou alguns pecuaristas a se desfazer de suas terras, a fim de saldar dívidas, e conforme enfatiza Oliveira (2008, p.239), a transformação de comerciantes em proprietários agrários apenas agravou a crise

\footnotetext{
${ }^{42}$ Ver BORGES, F. T. M., Do extrativismo à pecuária: algumas observações sobre a história econômica de Mato Grosso (1870 a 1930). Cuiabá, 1991, p. 43-45.
} 
das atividades urbanas, evidenciada já pela fuga e falência de comerciantes portuários do local.

A entrada de investimentos públicos para melhoria da infraestrutura da região do cerrado e pantanal mato-grossense proporcionou uma elevação dos preços das terras facilitando a concentração fundiária. A introdução de monoculturas voltada para o mercado nacional e internacional estimulou produtores agrícolas a buscar por novas terras, indo em direção ao norte de Mato Grosso, Rondônia, bem como para a faixa de fronteira da Bolívia e Paraguai.

Para tanto, Oliveira $(2009$, p. 36) elucida que na segunda metade da década de oitenta do século XX novos elementos redesenham a região. $\mathrm{O}$ comércio de produtos brasileiros de re-exportação para o lado boliviano cresceu com a expansão e diversificação produtiva da região de Santa Cruz de la Sierra.

Acompanhando essas mudanças regionais, as cidades bolivianas vizinhas de Corumbá mantiveram suas relações comerciais por meio do fornecimento não somente de produtos regionais como também de industrializados importados (OLIVEIRA, 1998; PAIXÃO, 2004). Além disso, essas cidades presenciam a migração de brasileiros para produzir soja e o aumento de empreendimentos internacionais para a exploração de minério (ferro) e extração de madeira.

Para tanto, foi a partir da década de 1950 que a densidade populacional das cidades da faixa de fronteira se diferenciou, com destaque para a cidade de Santa Cruz de la Sierra que salta de 42.746 habitantes e chega a ter 254.682 habitantes em menos de 30 anos. Já as cidades de Corumbá e Puerto Suarez cresceram às taxas de $178 \%$ e $270 \%$ respectivamente. 


\begin{tabular}{|c|c|c|c|c|c|}
\hline \multirow{2}{*}{ População Urbana } & \multicolumn{5}{|c|}{ Período da "vivificação" ou planejamento da fronteira (por ano) } \\
\hline & 1950 & 1960 & 1970 & 1976 & 1980 \\
\hline Corumbá & 24.336 & 38.841 & 51.199 & - & 67.561 \\
\hline Santa Cruz de la Sierra & 42.746 & - & - & 254.682 & - \\
\hline Puerto Suarez & 1.159 & - & - & 4.253 & - \\
\hline
\end{tabular}

TABELA 2 - População urbana da faixa de fronteira (Brasil e Bolívia), referente ao período da "vivificação" - 1950 a 1980.

Fonte: IBGE/Evolução da população segundo os municípios; MESA, GISBERT e GISBERT. "Historia de Bolivia", 2008, p.683.

Elaboração: SOKEN, D.

Em termos gerais, pode-se dizer que, o período de 1938 a 1955 para esta faixa de fronteira foi determinado pela expansão da pecuária extensiva realizada por brasileiros. Enquanto que no período de 1980 a 1990 a dinâmica foi dada pelo setor agroexportador a partir da hidrovia Paraguai - Paraná. E por fim, nos anos 2000 o comércio fronteiriço segue alimentando o fluxo de migrantes de todas as direções da Bolívia e do estado de Mato Grosso do Sul.

No que diz respeito à evolução da população a partir da década de 1990, observase que além da cidade de Santa Cruz de la Sierra outra cidade da fronteira se destaca: Puerto Quijarro que no ano de 1992 tinha 6.324 habitantes após uma década passa a ter 9.031 habitantes. E de acordo com os Censos de 2001 e 2012 a mesma continua crescendo, chegando a superar a taxa de crescimento populacional de Puerto Suarez que era de $41,3 \%$ e Puerto Quijarro obteve no mesmo período a taxa de $81,3 \%$.

\begin{tabular}{r|r|r|r|r|r|r}
\hline \multirow{2}{*}{ População Urbana } & \multicolumn{6}{|c}{ Período do comércio popular na fronteira (por ano) } \\
& \multicolumn{7}{|c|}{1991} & 1992 & 2000 & 2001 & 2010 & 2012 \\
\hline Corumbá & 76.660 & - & 86.144 & - & 93.452 & - \\
\hline Santa Cruz de la Sierra & - & 697.278 & - & 1.115 .391 & - & 1.442 .396 \\
\hline Puerto Suarez & - & 9.863 & - & 11.564 & - & 16.343 \\
\hline Puerto Quijarro & - & 6.324 & - & 9.031 & - & 16.373 \\
\hline
\end{tabular}

TABELA 3 - População urbana da faixa de fronteira (Brasil e Bolívia), referente ao período do comércio popular na fronteira" - 1991 a 2012.

Fonte: IBGE/Brasil/Censos demográficos de 1991, 2000 e 2010; INE/Bolívia/Censos demográficos de 1992,2001 e 2012

Elaboração: SOKEN, D.

Sobretudo, cabe ressaltar que o crescimento populacional de Puerto Quijarro aconteceu a partir da concentração de casas comerciais na linha de fronteira. Nos anos 1990 um grupo com duzentos comerciantes bolivianos iniciou a construção do prédio comercial de produtos populares, tal investimento atraiu inúmeros outros comerciantes 
da parte ocidental boliviana para Arroyo Concepción. Atualmente, esse aglomerado urbano está localizado na segunda seção do município de Puerto Quijarro e participa com a população de aproximadamente 5000 habitantes (INE, 2012).

A seguir, será introduzida uma análise macroeconômica sobre a taxa de câmbio, o nível de salário e os preços dos produtos de commodities que de certa forma norteiam o conjunto de ações que age ou pode influenciar esta faixa de fronteira, portanto, são esses elementos que alteram a dinâmica das relações transfronteiriças.

1.2.4.2. Vetores organizativos da fronteira: taxa de câmbio, nível dos salários mínimos e preços dos produtos de commodities.

Pretende-se nesta análise verificar os impactos dos vetores organizativos da fronteira a partir das relações entre as variáveis taxa de câmbio, nível de salário mínimo e preços dos produtos de commodities (SANTOS, 2006, p.149).

O ponto de partida abordará a discussão de recursos energéticos, a qual Fiori (2007) chama de fenômeno da nacionalização de empresas petroleiras ou revisão de contratos, que segundo o autor já tem sido realizado pelas grandes potências do continente americano (EUA), europeu (Grã-Bretanha, Alemanha), asiático (Japão, Coréia, China, Rússia), e que também ocorre nos países da América Latina como Bolívia, Peru, Equador, Argentina e Venezuela.

Para ele, o motivo dessa inflexão nacionalista é decorrente das novas demandas de recursos energéticos lideradas pelo eixo de consumo EUA, China e Índia.

Desta forma, a grande demanda e a disputa pelos recursos energéticos têm provocado, além do aumento dos preços dos recursos, “(...) o que fortalece a posição econômica e estratégica dos países exportadores", o avanço das grandes potências sobre os novos territórios econômicos subnacionais (FIORI, 2007, p.254 a 256).

Para José Luís Fiori ${ }^{43}$ a América Latina ${ }^{44}$ tem se beneficiado do boom econômico mundial liderado pelos EUA e China.

\footnotetext{
${ }^{43}$ FIORI, José Luis. O poder global e a nova geopolítica das nações. São Paulo: Boitempo Editorial, 2007.

${ }^{44}$ Segundo Fiori os Estados Unidos estão perdendo capacidade de intervenção e coordenação na América Latina. Segundo ele, "A América Latina é o único lugar do mundo onde nunca existiu disputa hegemônica interna. Primeiro, ela foi colônia e, em seguida, fronteira de expansão ou periferia da economia europeia.
} 
Sobretudo nos países com enormes excedentes minerais e recursos energéticos, como é o caso do cobre chileno ou do níquel cubano e, mais ainda, do petróleo e do gás da região andina. Além disso, o sobrepreço do petróleo, do gás e dos minerais em geral aumentou a capacidade fiscal autônoma desses Estados para financiar suas políticas públicas, assim como aumentou o grau de liberdade de suas políticas nacionais (FIORI, 2007, p. 252).

Segundo a máxima teórica de Fiori está sendo criado um espaço de oportunidade para se renegociar a hegemonia dos Estados Unidos dentro do próprio continente americano (FIORI, 2007, p.253).

De acordo com Fiori (2007, p. 185) a nova geografia econômica do sistema mundial tende a convergir para a economia e para a política, propiciando conexões e sobreposições entre o jogo geopolítico da defesa e da acumulação de poder e o jogo geoeconômico da monopolização e da acumulação da riqueza.

Para Fiori:

o que assistimos no mundo do petróleo e do gás natural é uma expansão veloz da demanda e um aumento da intensidade da competição entre os velhos e os novos grandes consumidores da energia disponível no mundo (FIORI, 2007, p.186).

Na opinião de Fiori (2007, p.187), o que é ainda mais complexo, além do aumento da oferta de energia e redistribuição das fontes de produção, é a entrada de novas grandes potências (Rússia, China e Índia) no jogo de poder das velhas grandes potências.

A partir desse cenário, cabe uma análise das variáveis macroeconômicas do Brasil e da Bolívia sobre a taxa de câmbio, o nível de salário e os preços dos produtos de commodities que, de certa forma, norteiam o conjunto de ações que afeta ou pode influenciar esta faixa de fronteira.

Com base no GRÁFICO 1 - "Taxa de câmbio em série do Brasil e da Bolívia, segundo moeda nacional por dólar estadunidense - 2001 a 2014”, verifica-se que a variação da taxa de câmbio boliviana do ano de 2001 até 2014 esteve em média 4 pontos acima da taxa brasileira, o que reforça a estratégia da política econômica boliviana de estímulo às exportações de commodities.

Depois de sua independência, esteve sempre sob a égide anglo-saxônica: da Grã-Bretanha, até o fim do século XIX, e dos Estados Unidos, até o início do século XXI. (...). E tampouco se formou na América Latina um sistema integrado e competitivo, de Estados e economias nacionais, como viria a ocorrer na Ásia, depois de sua descolonização". Essa diminuição da capacidade de intervenção é fruto, em parte, do sucesso econômico global da América Latina (FIORI, 2007, p. 251 a 253). 
Especialmente na faixa de fronteira as variações da taxa de câmbio têm influência direta no comércio local, é uma forma de obter capital de giro. A troca de moedas possibilita aos comerciantes comprar e vender os produtos mais baratos, o que determina as vantagens comparativas nessas localidades de fronteira.

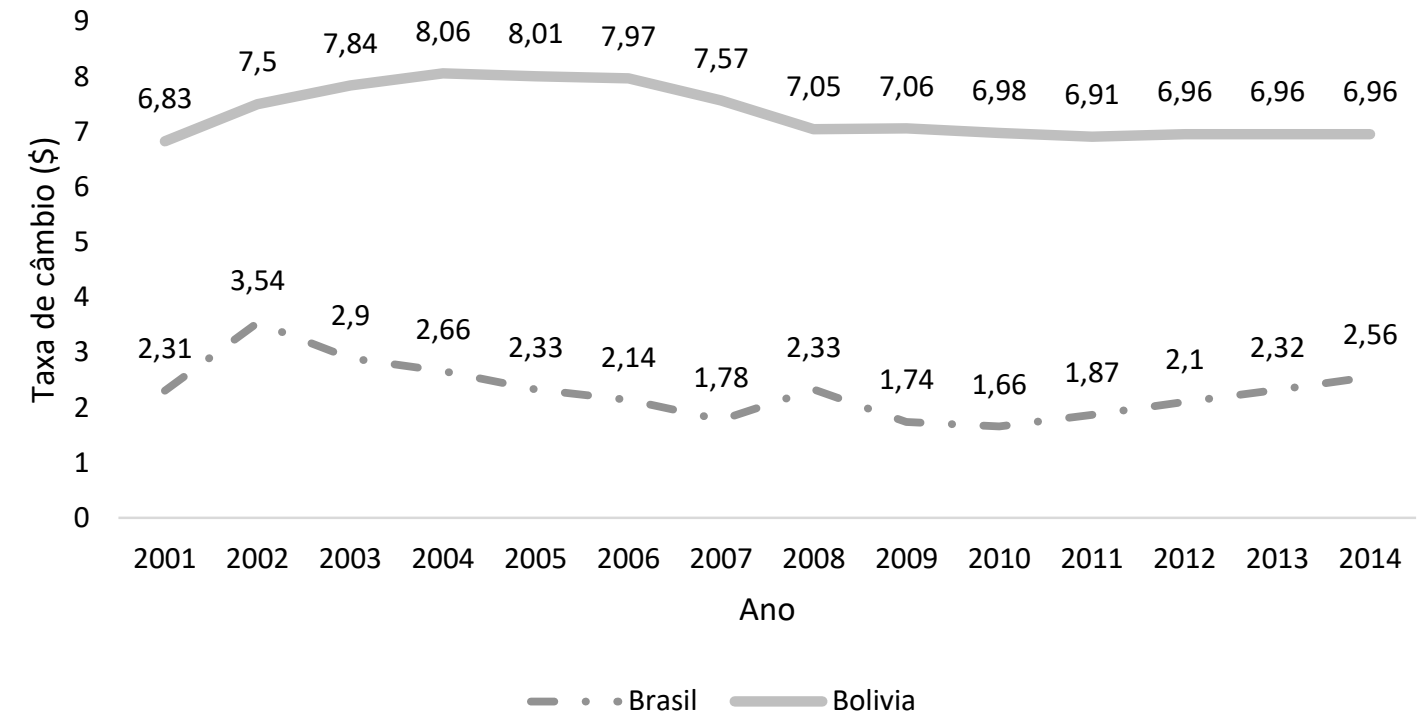

GRÁFICO 1 - Taxa de câmbio em série do Brasil e da Bolívia, segundo moeda nacional por dólar estadunidense - 2001 a 2014.

Fonte: Banco Central da Bolívia/INE. Banco Central do Brasil.

Elaboração: SOKEN, D.

Já em relação ao nível de salário mínimo da Bolívia, observa-se que se manteve estacionado. Apesar da presença da Petrobrás neste país, que desde 1996 tem produzido, ao longo de uma década, o equivalente a $15 \%$ do PIB e é responsável por $1 / 4$ da arrecadação fiscal boliviana, o nível do salário sofreu poucas alterações (VILARINO, 2010, p.149).

No entanto, a partir da nacionalização dos hidrocarbonetos por decreto lei no ano de 2006 o governo boliviano passou a arrecadar mais que as empresas multinacionais, agora recebe $82 \%$ da receita do gás e do petróleo contra $18 \%$ para as empresas. E segundo Vilarino (2010, p.144), já no ano de 2006 foi possível reajustar o salário mínimo em 13\%, congelado por três anos, além disso, com base na receita dos hidrocarbonetos criou um programa de ajuda às famílias mais pobres, chamado de "renda mínima". 


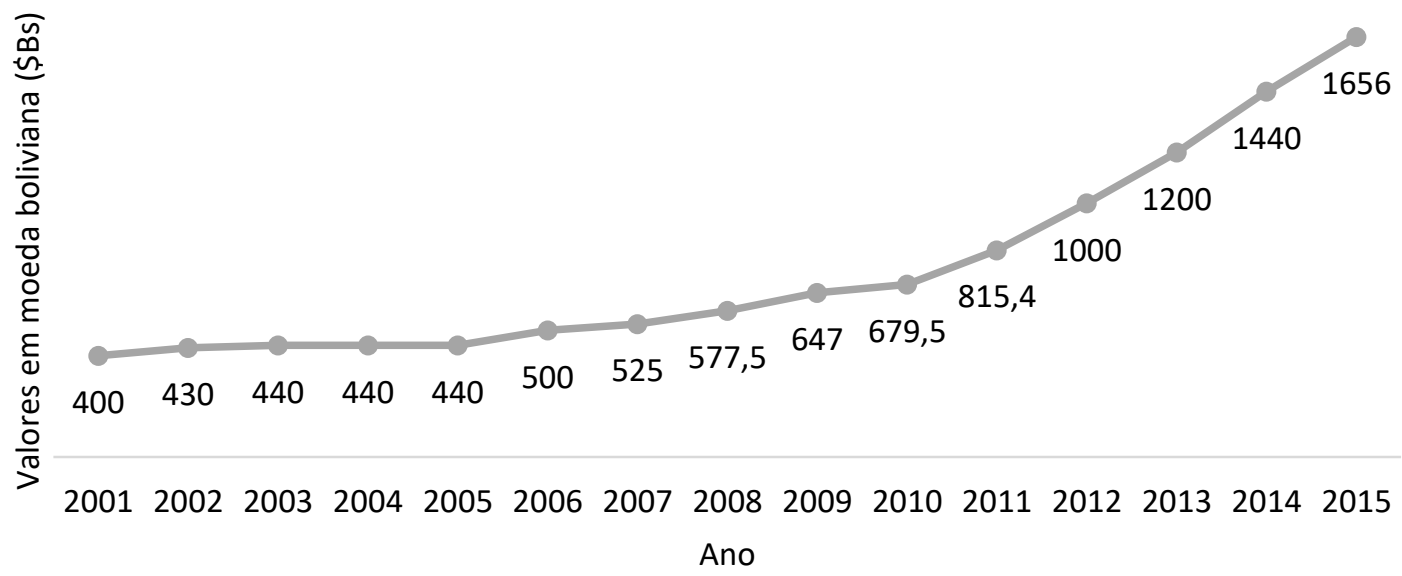

GRÁFICO 2 - Salário mínimo nominal da Bolívia, segundo os anos de 2001 a 2015, em moeda local. Fonte: Diário Oficial da Bolívia/INE

Elaboração: SOKEN, D.

O valor do salário mínimo no ano de 2001, início da exploração de petróleo pela Petrobrás na Bolívia, era de B \$ 400,00 (quatrocentos bolivianos), teve um aumento de $7,5 \%$ no ano seguinte e mais $2,3 \%$ no ano de 2003 e se mantém constante até 2005 . A partir do decreto lei de 2006, o salário sobe para B \$ 500,00 (quinhentos bolivianos) e numa média ascendente de crescimento de $10 \%$ a $15 \%$ atinge o valor de B $\$ 1.656,00$ (mil seiscentos e cinquenta e seis bolivianos) no ano de 2015.

Já a variação do salário mínimo do Brasil, a partir de 2001 até 2015 teve um aumento médio de $11 \%$. Considerando a variação média da taxa de inflação brasileira que esteve em torno do "teto" da meta de 6,5\% ao ano, essa elevação nominal do salário em pouco impactou nos ajustes da política monetária, uma vez que no ano de 2002 o valor nominal que era de $\mathrm{R} \$ 200,00$ passou para $\mathrm{R} \$ 350,00$ no ano de 2006 e, mesmo assim, a taxa de inflação esteve em queda, de 12,53\% no ano de 2002 caiu para 3,14\% em 2006. 


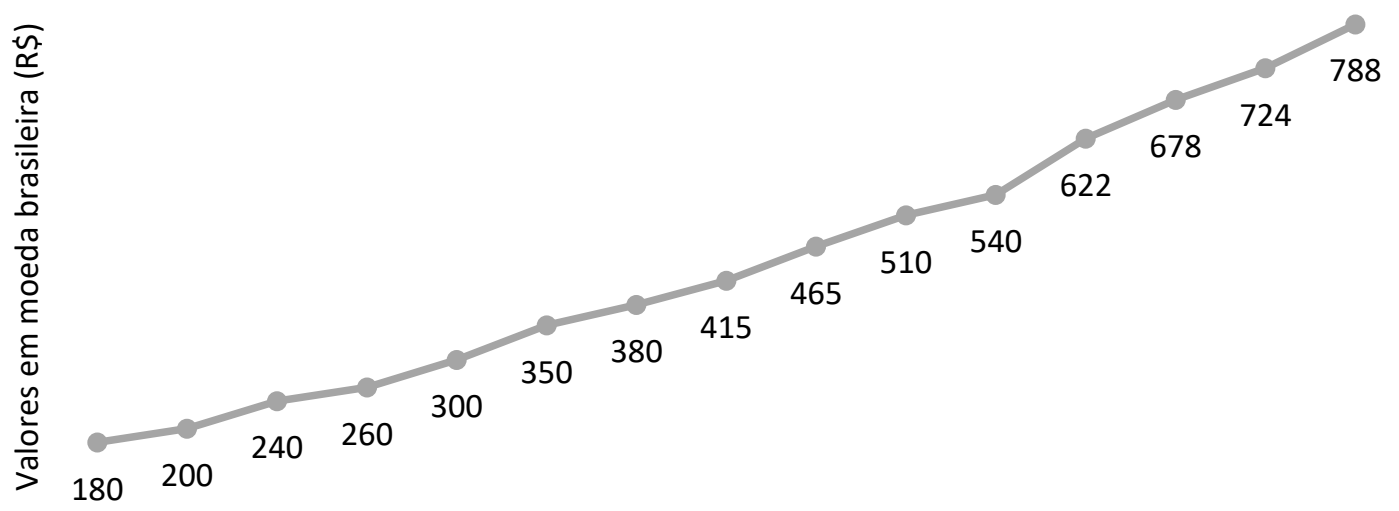

200120022003200420052006200720082009201020112012201320142015

Ano

GRÁFICO 3 - Salário mínimo nominal do Brasil, segundo os anos de 2001 a 2015, em moeda local. Fonte: DIEESE, vários anos.

Elaboração: SOKEN, D.

A elevação das taxas de inflação brasileira, principalmente das décadas de $1980 \mathrm{e}$ 1990, impactou positivamente nas relações comerciais da fronteira entre Brasil e Bolívia e significou aumento de cinco vezes a mais de estabelecimentos comerciais atacadista em relação aos varejistas, especialmente do comércio de produtos alimentícios industrializados. O mercado de exportação de produtos alimentícios do Brasil tem como destino principal a cidade de Santa Cruz de La Sierra, tal fato teve como estímulo o poder de compra da moeda americana frente à desvalorização da moeda brasileira e às variações de preços dos produtos brasileiros, isso resultou em maior competitividade comercial para as empresas brasileiras. 


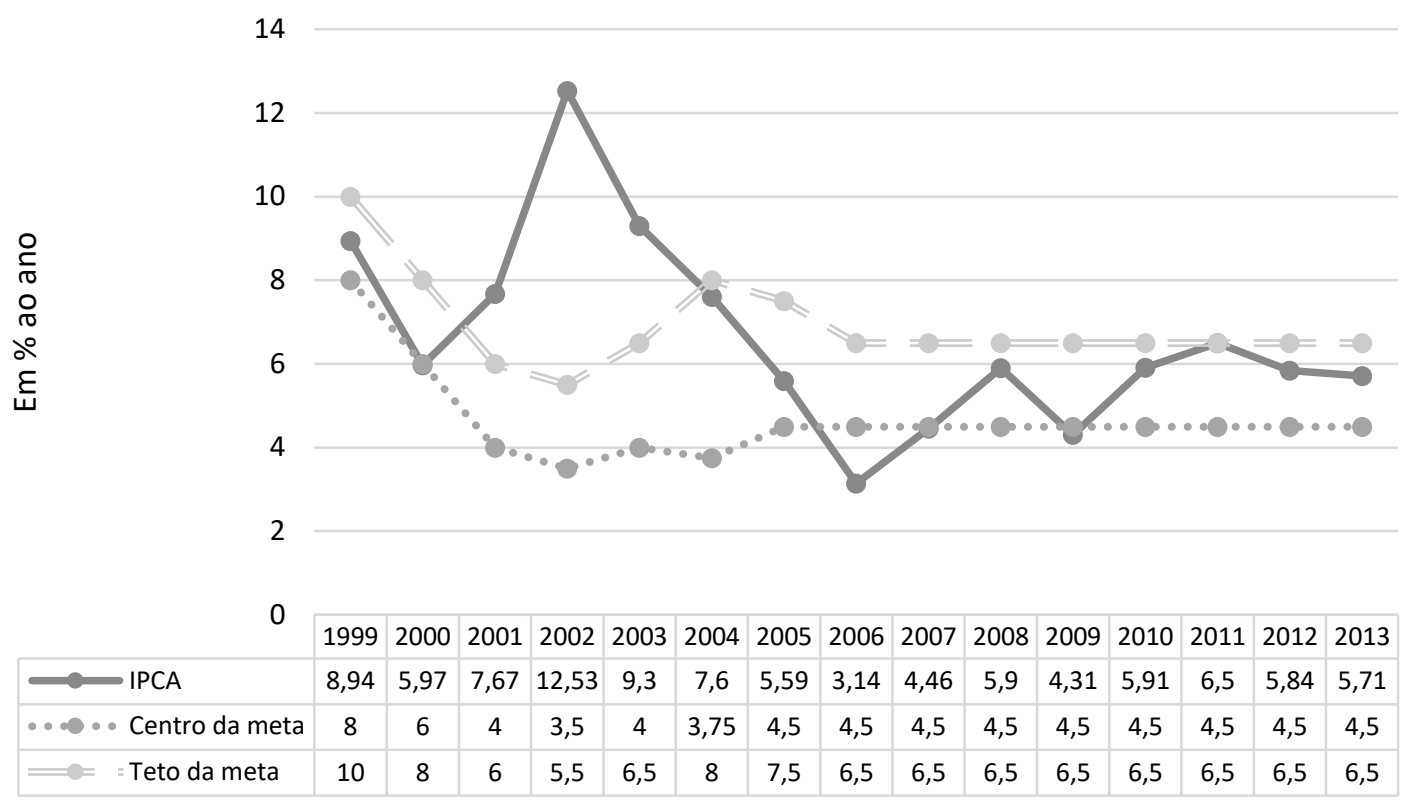

GRÁFICO 4 - Regime de meta de inflação no Brasil: inflação (IPCA-IBGE), centro e "teto" da meta, 1999 a 2013*, em \% ao ano.

Fonte: Sidra-IBGE e BC.

Organização: Subseção DIEESE/CUT-Nacional

Nota: * Estimativa do IPCA-IBGE do Banco Central do Brasil para o ano.

Desta forma, com base na Nota Técnica do DIEESE (2013, p.11), verifica-se que a elevação da taxa de inflação brasileira a partir de 2012 teve como motivo a pressão dos preços alimentícios. O movimento dos preços internacionais tem acumulado alta de até 8\% nos produtos agrícolas, segundo Índice de Commodities do Banco Central. Neste ano também houve quebra de safra dos produtos de grãos e derivados na América do Norte, além disso, no Brasil os problemas relacionados ao clima brasileiro impactaram na oferta de produtos agrícolas no geral.

No entanto, com base nos dados do GRÁFICO 4 -"Regime de meta de inflação no Brasil: inflação (IPCA-IBGE), centro e "teto" da meta, 1999 a 2013*, em \% ao ano" é possível realizar a análise sobre a especialização dos lugares que Cataia aborda a partir da:

competição territorial como uma das facetas da especialização dos lugares e o pressuposto dessa competição é, (...), a existência das fronteiras. A especialização dos lugares em função de suas atividades econômicas aprofunda a divisão territorial do trabalho. Esta comanda a produtividade espacial e alarga a competitividade entre os lugares (CATAIA, 2001, p.213).

A partir da crítica de Sanchez (1997) sobre as condições naturais de David Ricardo, Cataia acrescenta o território como norma, portanto, diz que: 
(...) as vantagens comparativas não se apoiam mais nos recursos físicos disponíveis no lugar, mas em diferenças culturais (hierarquização social), políticas (repressão, segurança), exploração (baixos salários), gênero (uso da força de trabalho feminina pagando menores salários), mercados de trabalho (força de trabalho pouco exigente), econômicas (incentivos e isenções fiscais), mas apoiam-se também nos recursos físicos criados, ou seja, no território como norma (CATAIA, 2001, p.214).

De acordo com a tabela de índices do DIEESE (2013, p.11), tanto o Índice Commodity Research Bureau (CRB) quanto o Índice de Commodities do Banco Central (IC-Br) indicam queda nos preços dos produtos de commodities. Aquele mostrou que no primeiro trimestre de 2013 teve queda de 5,37\%, enquanto o outro índice apontou queda de 6,24\% dos produtos da agropecuária para o mesmo período. Sendo assim, considerase que os preços dos produtos de commodities no geral tendem à distensão.

Wanderley Messias, de acordo com as anotações de sala de aula, pensa as políticas de integração dos países da América Latina considerando a inserção ativa no processo de reestruturação global - cuja articulação Bolívia-Brasil está entre Santa Cruz, Beni e Pando com Rondônia e Mato Grosso, a partir dos investimentos em infraestrutura vinculados ao setor do agronegócio. 


\begin{tabular}{|c|c|c|c|c|c|}
\hline Período & $\begin{array}{c}\text { IC-BR } \\
\text { (Composto) }\end{array}$ & $\begin{array}{c}\text { IC- } \\
\text { BrIAgropecuária } \\
\text { (1) }\end{array}$ & $\begin{array}{l}\text { IC- } \\
\text { Br/Metal } \\
(2)\end{array}$ & $\begin{array}{c}\text { IC- } \\
\text { Br/energia } \\
\text { (3) }\end{array}$ & CRB(4) \\
\hline $\mathrm{dez} / 05$ & 100,00 & 100,00 & 100,00 & 100,00 & 100,00 \\
\hline dez/06 & 105,06 & 103,23 & 143,62 & 75,01 & 112,16 \\
\hline dez/07 & 100,17 & 101,04 & 115,92 & 81,71 & 107,37 \\
\hline dez/08 & 102,64 & 115,29 & 81,95 & 79,57 & 107,13 \\
\hline dez/09 & 99,32 & 107,51 & 102,11 & 67,89 & 105,89 \\
\hline $\mathrm{dez} / 10$ & 124,77 & 137,62 & 122,98 & 81,06 & 124,71 \\
\hline dez/11 & 124,34 & 136,96 & 109,72 & 92,00 & 128,29 \\
\hline jan/12 & 125,05 & 138,07 & 113,25 & 88,62 & 127,00 \\
\hline fev/12 & 121,35 & 132,59 & 114,16 & 86,98 & 124,65 \\
\hline $\mathrm{mar} / 12$ & 124,59 & 135,16 & 117,13 & 92,58 & 130,96 \\
\hline$a b r / 12$ & 125,32 & 136,04 & 117,46 & 92,96 & 132,37 \\
\hline mai/12 & 127,16 & 137,92 & 119,96 & 93,89 & 138,83 \\
\hline jun/12 & 125,37 & 137,64 & 117,56 & 87,48 & 141,42 \\
\hline $\mathrm{jul} / 12$ & 135,17 & 151,92 & 115,49 & 92,79 & 141,82 \\
\hline ago/12 & 135,05 & 150,53 & 113,16 & 99,37 & 144,06 \\
\hline set/12 & 135,45 & 149,20 & 122,27 & 98,11 & 145,51 \\
\hline out/12 & 134,49 & 147,67 & 121,45 & 99,06 & 143,54 \\
\hline nov/12 & 135,41 & 147,98 & 122,51 & 101,83 & 143,58 \\
\hline $\mathrm{dez} / 12$ & 137,40 & 149,06 & 131,39 & 100,68 & 146,45 \\
\hline jan/13 & 135,46 & 146,30 & 132,14 & 99,12 & 143,56 \\
\hline fev/13 & 131,44 & 140,70 & 129,87 & 99,02 & 138,47 \\
\hline mar/13 & 129,05 & 139,76 & 122,05 & 96,54 & 138,59 \\
\hline
\end{tabular}

TABELA 4 - Índices de Commodities do Banco Central (IC-Br) e Commodity Research Bureau (CRB), de dezembro de 2005 a março de 2013, em número índice (base: dezembro de 2005=100)

Fonte: Banco Central

Organização: DIEESE

Nota: 1) Composição: carne de boi, algodão, óleo de soja, trigo, açúcar, milho, café, arroz e carne de porco; 2) Composição: alumínio, minério de ferro, cobre, estanho, zinco, chumbo e níquel; 3) Composição: petróleo brent, gás natural e carvão; 4) Índice de preços de commodities, baseado no mercado à vista, calculado pelo Commodity Research Bureau (CRB). O Índice é uma medida dos movimentos de preços de produtos básicos mais sensíveis a mudanças nas condições econômicas.

Entende-se que a nova divisão territorial do trabalho exige dos lugares estratégias inovadoras. Pois, as economias que têm os produtos de commodities como principal fonte de renda encontram sérias restrições de crescimento, uma vez que os preços internacionais tendem a queda.

Na sequência, será apresentado a área de pesquisa e as características do comércio popular da fronteira boliviana. É importante salientar que nos últimos 30 anos as relações transfronteiriças têm sido intensificadas pelas atividades comerciais, produtivas e culturais com uso da mão de obra feminina. 


\subsubsection{A recente dinâmica do comércio popular na fronteira boliviana}

Quanto ao entendimento sobre o comércio popular na fronteira boliviana, de acordo com Tassi et al (2013), a expansão desse tipo de comércio é decorrente da flexibilidade produtiva do consórcio familiar chinês que adapta os produtos conforme as necessidades locais (qualidade, aparência, marca, embalagem e preço), bem como, o manejo de pequenos lotes distribuídos pelas redes comerciais de produtos populares com custo mínimo (TASSI et al, 2013, p. 79 e 80).

A sofisticação desse tipo de comércio popular está na comercialização de imitação de grandes marcas com preço inferior ao original, além de oferecer o produto com marca própria. Outro fato que acelerou a inserção em massa de produtos chineses no território boliviano é a política migratória que facilita os pequenos comerciantes migrarem e também a baixa burocratização e institucionalização para exportar (TASSI et al, 2013, p. 79 e 80$)$.

Já as relações oficiais entre o governo boliviano com o empresariado chinês tratam-se apenas de acordos produtivos no setor de infraestruturas (telecomunicações e rodovias), bem como de produção de baterias de lítio e fabricação de açúcar (TASSI et al, 2013, p.82).

Segundo Tassi et al (2013, p. 82 e 83) a política tributária do Governo Movimento Al Socialismo - MAS dinamizou as economias locais mediante investimentos em logística com a construção e expansão de redes de transporte provincial e interprovincial, o que ampliou as possibilidades de articulação entre a cidade e o campo.

Com base nas entrevistas realizadas nas cidades-gêmeas de fronteira, é importante ressaltar a opinião de comerciantes da Associação Comercial "12 de Octubre" (Feirinha) a respeito da política institucional do Governo MAS para a área de fronteira boliviana, segundo a autoridade do local:

Com a entrada do governo de Evo Morales aconteceu melhorias nas áreas de fronteira da Bolívia, por exemplo a conclusão da pavimentação da rodovia que liga a fronteira da Bolívia até Santa Cruz de la Sierra, projeto de vinte e cinco anos atrás; a expansão e melhoria dos serviços de internet e telefonia nas áreas 
de fronteira propiciou maior aproximação com as cidades do interior da Bolívia (informação verbal) $)^{45}$.

Além disso, destaca Tassi et al (2013, p.83) sobre a importância das redes de comércio popular que possibilita ao Estado controlar o território e a fronteira. Entende-se que quando o Estado direciona os investimentos em infraestrutura ele reorganiza o território e oferece novas especializações produtivas.

Para tanto, percebe-se que o governo estimula a expansão desse tipo de atividade para às margens do seu território. Cabe destaque para o distrito industrial de El $\mathrm{Alto}^{46}$ enquanto reduto dos comerciantes de importação e exportação do setor têxtil e confecção e das redes capilares de comerciantes populares que atendem a multiplicidade de territórios e mercados da fronteira. De acordo com Tassi et al:

No hay duda de que el comercio popular - y sobre todo aymara - ha ido incursionando y afirmándose en las regiones fronterizas, como el Norte amazónico, pero también Villazón, Desaguadero y las fronteras y puertos chilenos (...) Sin embargo, el comercio popular juega una función importante em la articulación y en generar sinergias entre los mercados urbanos e intermédios y las realidades rurales o fronterizas (TASSI et al, 2013, p.115) ${ }^{47}$.

Para fins de compreender as questões relativas a expansão do comércio popular com a introdução de mão de obra feminina nas extremidades do território boliviano, farse-á uso de imagens e entrevistas realizadas em agosto de 2008 e setembro de 2014 nas cidades-gêmeas da fronteira entre Brasil e Bolívia.

Desta forma, considera-se relevante explicar o aceleramento do comércio nas fronteiras bolivianas e incorporação do trabalho feminino nas cidades-gêmeas, para isso destacam-se dois aspectos importantes, são eles: os vínculos familiares e de amizades que organizam os negócios e os contratos de trabalho somados à vasta oportunidade de

\footnotetext{
${ }^{45}$ Entrevista concedida por Sr. C.F.. Entrevista I [set. 2014]. Entrevistadora: Dirce Sizuko Soken. Puerto Quijarro, 2014. 1 arquivo mp3 (13 min.).

${ }^{46}$ (informação verbal) Revela o Sr. M.V.: "Na Bolívia em La Paz na localidade de El Alto o governo criou incentivo para as fábricas que produzem as roupas de marcas, com uso de mão de obra boliviana fazem os cortes das roupas originais e exportam para os EUA que de certa forma depois essas roupas são copiadas e passam a circular na Bolívia e vendidas a preço mais baixo" (M.V.. Entrevista XXVI [set. 2014]. Entrevistadora: Dirce Sizuko Soken. Puerto Quijarro, 2014. 1 arquivo mp3 (60 min.)).

${ }^{47}$ Tradução: Não há dúvida que o comércio popular - e sobretudo aymara - vem se inserindo e se consolidando nas regiões fronteiriças, como no Norte amazônico, mas também em Villazón, Desaguadero e nas fronteiras e nos portos chilenos (...). No entanto, o comércio popular tem um papel importante na articulação e na elaboração de sinergias em mercados urbanos e intermediários e em realidades rurais ou fronteiriças.
} 
realizar negócios de compra e venda por toda a Bolívia, tais aspectos ajudam a compreender a formação e reprodução do comércio em cidades de fronteira.

Segundo a percepção do entrevistado Sr. M.V, a forma de organização do comércio da fronteira boliviana é uma réplica da estrutura do comércio popular da cidade de Santa Cruz de La Sierra. Revela ainda que na fronteira entre Bolívia e Argentina está se desenvolvendo da mesma forma no que se refere a organização do trabalho, segundo ele:

O comércio boliviano na fronteira entre Bolívia e Argentina é significativo e também segue a mesma reprodução da organização comercial de Santa Cruz de la Sierra. O uso da mão de obra masculina e feminina dos comerciantes de etnia Aymara é intensiva e sob subordinação do comerciante argentino. Essa relação se mantém até o momento em que esses trabalhadores conquistam bens de luxo e logo, se deslocam para outras localidades em busca de melhores oportunidades de negócios. Isso estabelece um ciclo de acumulação que se renova a cada dois anos (conhecidos por investimentos nômades, "chitana"). O auge da acumulação ocorre até a metade do ano e depois estabiliza até o final do ano (informação verbal) $)^{48}$.

O entrevistado observa ainda que, a partir da queda do comércio de terras na Bolívia $^{49}$, uma nova geração de camponeses se insere em atividades voltadas para a vida nas cidades, comenta que:

Os comerciantes na fronteira são mestiços, representam a nova geração de campesinos que ao ter maior experiência com o comércio se tornam pequenos empresários e se desvinculam do campo. Adotam outras formas de inserção econômica, mediante a instrução universitária dos filhos que lhes possibilitam ascensão social (informação verbal) ${ }^{50}$

Na sequência, constata-se que na Bolívia a estrutura organizacional do trabalho é regida preferencialmente pelas relações familiares de trabalho, as quais viabilizam o processo de ocupação e acumulação mercantil no espaço transfronteiriço, especialmente localizado na faixa de fronteira.

\footnotetext{
${ }^{48}$ M.V.. Entrevista XXVI [set. 2014]. Entrevistadora: Dirce Sizuko Soken. Puerto Quijarro, 2014. 1 arquivo $\mathrm{mp} 3$ (60 $\mathrm{min}$.).

49 (informação verbal) De acordo com relato do Sr. M.V.: os campesinos do altiplano que se deslocaram para o lado oriental da Bolívia encontraram dificuldades para organizar o plantio, que exigia maior tempo de dedicação e mão de obra para o cultivo. Isso resultou em adoção de outras estratégias por parte dessa população, que foi de ocupar terras e vender, que os tornou comerciantes de terras, posteriormente comerciantes de produtos industrializados, tais como carro (M.V.. Entrevista XXVI [set. 2014]. Entrevistadora: Dirce Sizuko Soken. Puerto Quijarro, 2014. 1 arquivo mp3 (60 min.))”.

${ }^{50}$ M.V.. de. Entrevista XXVI [set. 2014]. Entrevistadora: Dirce Sizuko Soken. Puerto Quijarro, 2014. 1 arquivo $\mathrm{mp} 3$ (60 $\mathrm{min}$.).
} 
As trabalhadoras procedentes do altiplano e de cidades do interior da Bolívia que se deslocam até a fronteira oriental são atraídas por melhores salários oferecidos por familiares e/ou conhecidos que possuem estabelecimentos comerciais de vestuário. Segundo dados coletados pela pesquisa, a média salarial de algumas mulheres que se sujeitam a trabalhar e dormir no local de trabalho totaliza até mil e quinhentos bolivianos ${ }^{51}$.

O contrato de trabalho conhecido por "cama adentro" é oferecido àquelas trabalhadoras temporárias que vêm de outras localidades, a grande maioria vem da cidade vizinha de Puerto Suarez. As lojas preferem esse tipo de contrato porque a jornada de trabalho pode ser ajustada de acordo com o fluxo de consumo realizado pelas "sacoleiras brasileiras" que chegam de ônibus fretado de madrugada e deixam a fronteira ao meiodia. Após essa jornada de trabalho, se não tiverem compradores podem fechar a loja e abrir após o horário do almoço. Essa rotina acontece durante a semana de segunda-feira a sábado. No domingo, após o meio-dia as lojas fecham e essas trabalhadoras retornam para suas residências em Puerto Suarez.

Desta forma, é comum a construção de prédios comerciais com dupla função produtiva, onde se possibilita a realização de atividades comerciais e também serve de alojamento para as trabalhadoras temporárias. Ao redor dessa linha de fronteira existem centenas de construções que replicam essa forma de organização comercial.

\footnotetext{
${ }^{51}$ (informação verbal) Informa Sr. M.V. que essa forma de contratado denomina-se de "cama adentro", onde o funcionário aceita abrir a loja às 4 horas da madrugada e fecha às 19 horas. Esse tipo de contrato representa uma faixa salarial bem acima da média paga na cidade por outras atividades, por exemplo, uma telefonista recebe até novecentos bolivianos por oito horas de trabalho (M.V.. Entrevista XXVI [set. 2014]. Entrevistadora: Dirce Sizuko Soken. Puerto Quijarro, 2014. 1 arquivo mp3 (60 min.)).
} 


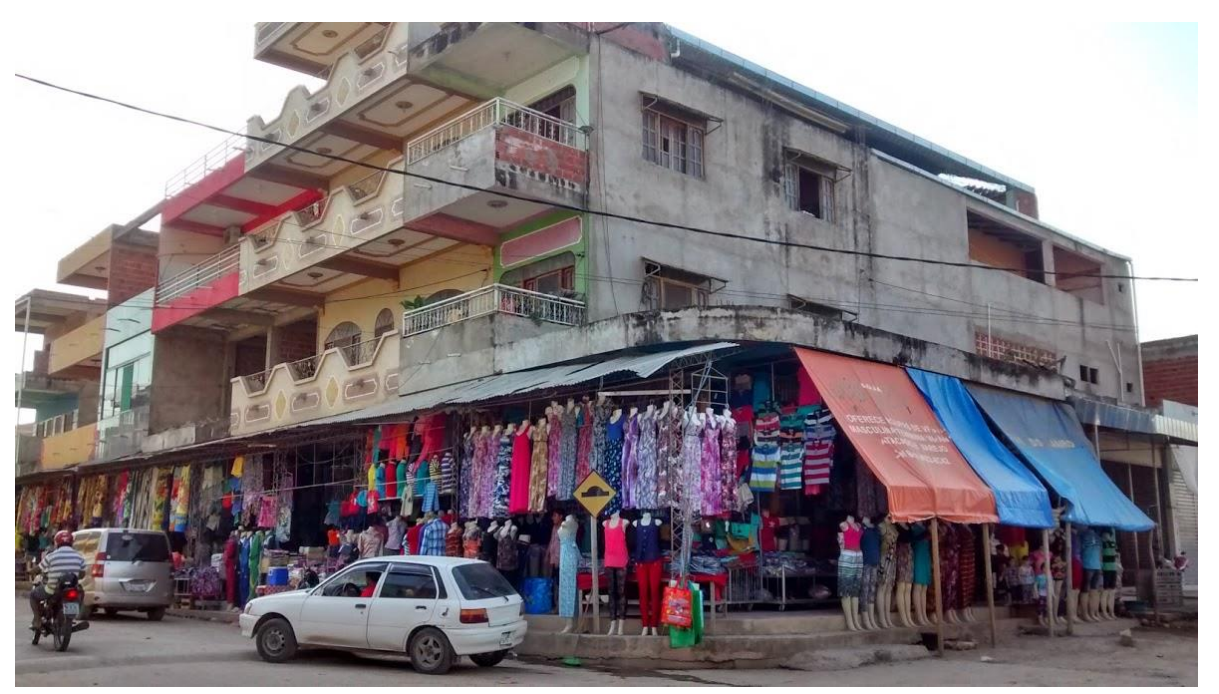

FOTO 1- Bolívia, Arroyo Concepción em Puerto Quijarro, prédios comerciais que abrigam trabalhadoras temporárias denominadas de "cama adentro".

Foto: SOKEN, D., setembro de 2014

O comércio popular da fronteira é formado por associações de comerciantes onde cada associação se apresenta como uma única pessoa jurídica, tal configuração jurídica possibilita a esses comerciantes se inscreverem no regime mínimo de tributação. Além disso, proporciona ao grupo poder político ${ }^{52}$, uma vez que o movimento comercial na linha da fronteira pode ultrapassar a um milhão de dólares. O Estado boliviano incentiva a formação de associações e investimentos comunitários que de certa forma propiciam investimentos privados na infraestrutura local em favor da manutenção da carga tributária baixa. Assim revelou sr. M.V.: "Todo mundo trabalha para todo mundo" (informação verbal $)^{53}$

Para fins de demonstração dos investimentos realizados na linha de fronteira, farse-á o uso de imagens referente ao intervalo de seis anos, que permite observar os distintos momentos de acumulação mercantil, a partir das condições da infraestrutura urbana da Calle 12 de Octubre - principal rua do comércio popular da linha de fronteira. A imagem retratada em agosto de 2008 evidência a ocupação desordenada do espaço urbano pelo comércio de fronteira, onde as ruas sem asfaltamento e sem calçamento, prédios em construção, falta de ordenamento dos locais para estacionamento de veículos automotivos, fachadas dos estabelecimentos comerciais feitas de lona representam o

\footnotetext{
${ }^{52}$ Há presença significativa de comerciantes Aymaras nos comitês cívicos de Puerto Quijarro.

${ }^{53}$ M.V. Entrevista XXVI [set. 2014]. Entrevistadora: Dirce Sizuko Soken. Puerto Quijarro, 2014. 1 arquivo mp3 (60 min.).
} 
tempo de negociação entre a associação de comerciantes com órgãos públicos para tratar dos tributos e inversões na infraestrutura urbana.

No geral, os comerciantes de produtos populares na Bolívia não investem em fachadas e instalações dos prédios comerciais, a exemplos de grandes importadores de La Paz que em outros tempos já investiram em grandes "tiendas" em Puerto Suarez e Desaguadero, hoje não investem em "tiendas" fixas em locais de fronteira em razão da volatilidade das condições econômicas e das oportunidades de negócios que surgem por toda a Bolívia, isso tem motivado os comerciantes populares a manter uma estrutura física bem enxuta, uma vez que podem ganhar com a mobilidade. Além disso, os custos de manutenção das "tiendas" tais como: aluguel e luz não compõem o preço final dos produtos (TASSI et al, 2013, p. 158).

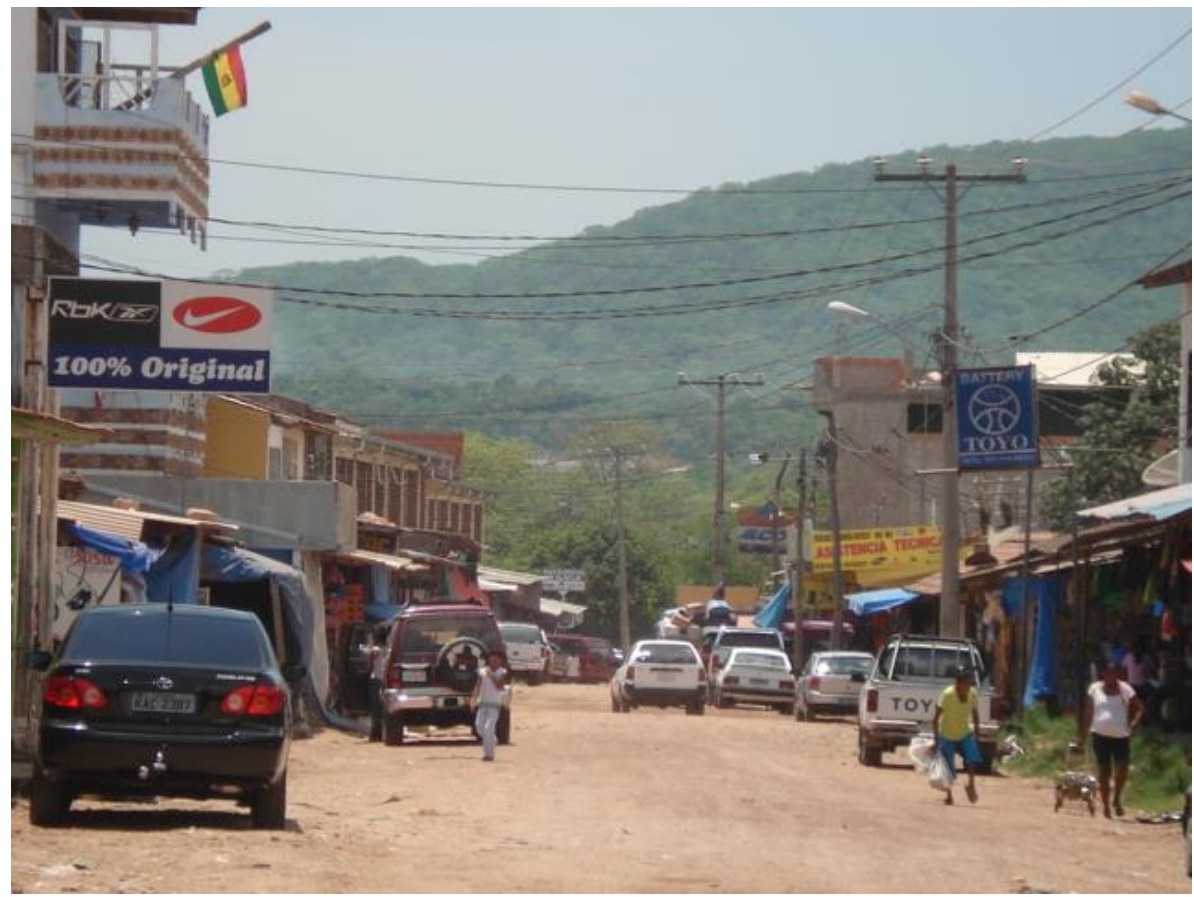

FOTO 2 - Bolívia, Arroyo Concepción em Puerto Quijarro, Calle 12 de Octubre, principal centro comercial de produtos populares, fotografado em agosto de 2008

Foto: SOKEN, D., agosto de 2008 


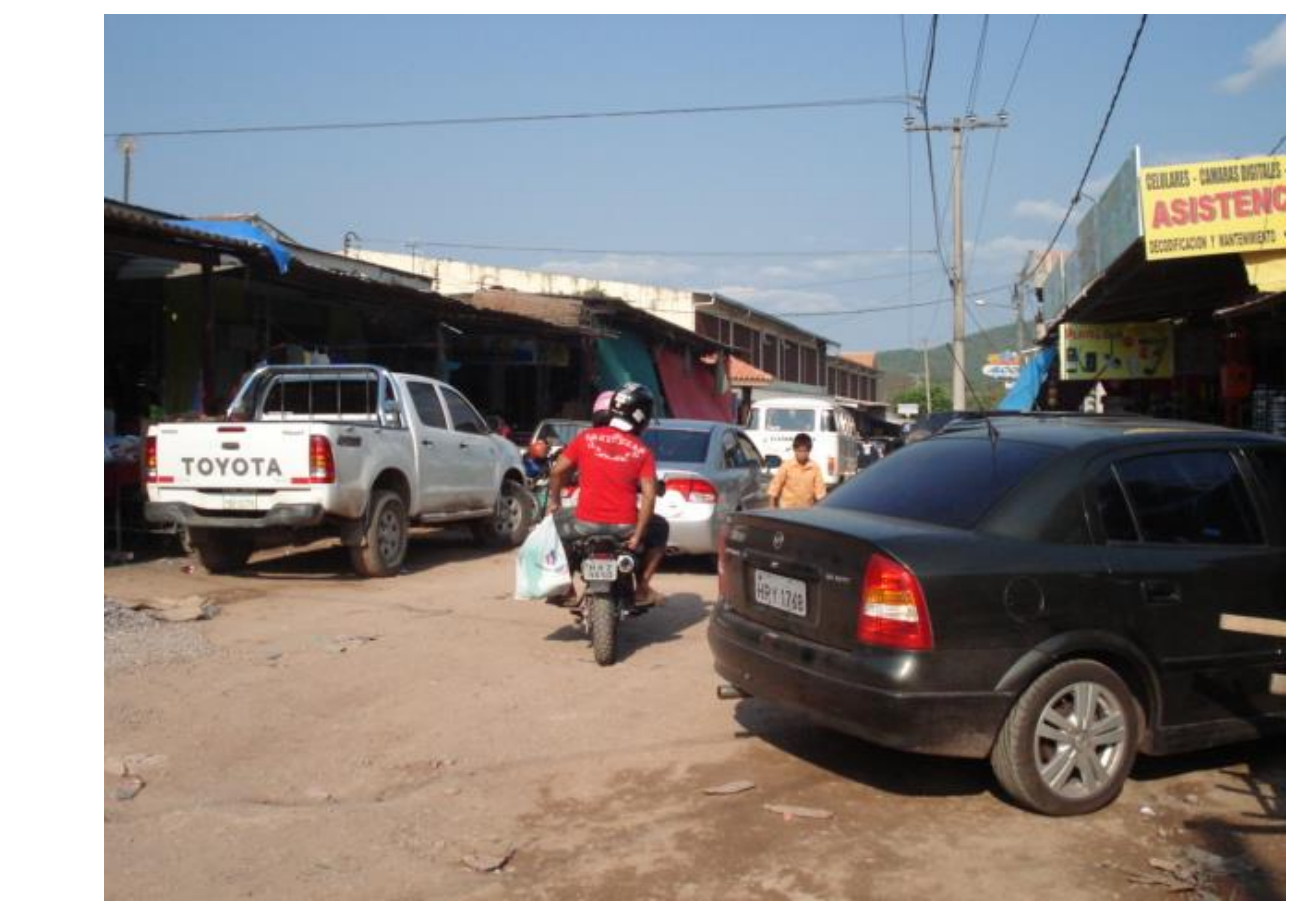

FOTO 3 - Bolívia, Arroyo Concepción em Puerto Quijarro, Calle 12 de Octubre, principal centro comercial de produtos populares, fotografado em agosto de 2008.

Foto: SOKEN, D, agosto de 2008

Passados seis anos, registram-se melhorias nas condições de infraestrutura urbana da principal rua do comércio popular da fronteira, como o asfaltamento, o calçamento e o ordenamento do estacionamento de veículos da rua "12 de Octubre", bem como, os prédios foram construídos e as fachadas tiveram algumas melhorias, embora ainda é possível encontrar alguns estabelecimentos com fachadas feito de lona.

Os prédios comerciais populares na fronteira são estruturas multifuncionais atendem as necessidades de moradia dos comerciantes, alojamentos de trabalhadores, depósitos de mercadorias e também são espaços para festas. Segundo Tassi et al (2013, p. 158) são lugares de forte integração entre espaços sociais e de negócios, muitos comerciantes utilizam salas e quartos como depósitos das mercadorias para não gerar custos com aluguel de armazéns. 


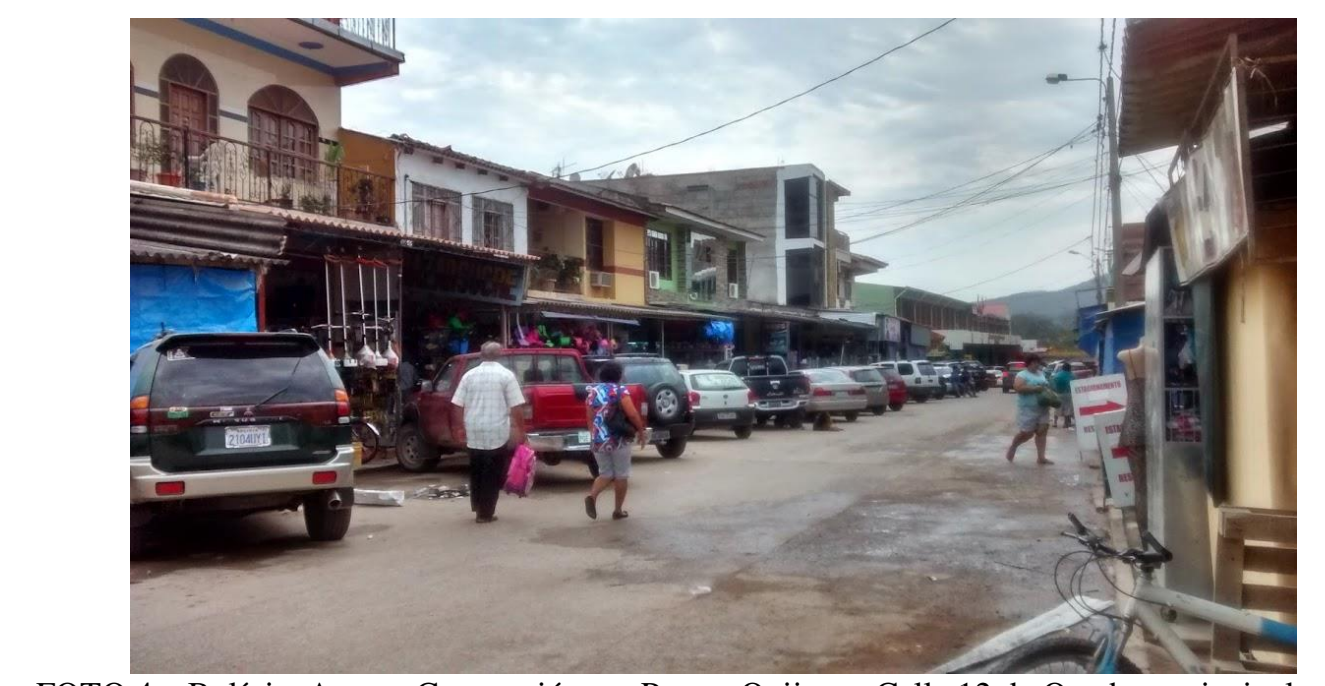

FOTO 4 - Bolívia, Arroyo Concepción em Puerto Quijarro, Calle 12 de Octubre, principal centro comercial de produtos populares, fotografado em setembro de 2014.

Foto: SOKEN, D, setembro de 2014

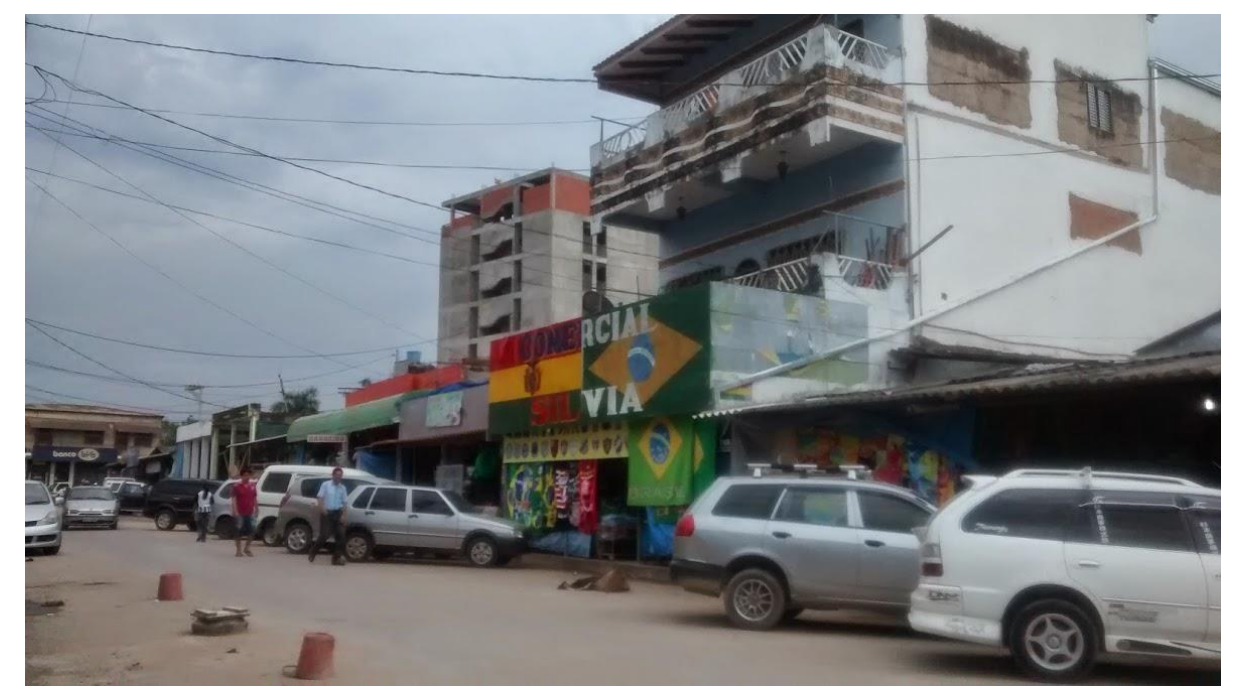

FOTO 5 - Bolívia, Arroyo Concepción em Puerto Quijarro, Calle 12 de Octubre, principal centro comercial de produtos populares, fotografado em setembro de 2014.

Foto: SOKEN, D, setembro de 2014

O comércio popular da fronteira é formado por pequenas unidades familiares que se juntam e formam grupos que cooperam entre si. Esse formato organizacional permite obter ganhos de escalas no momento de comprar as mercadorias. Tal situação de certa maneira impôs a esta fronteira a especialização no comércio de confecção.

Sobretudo, é a rede social familiar que faz o comércio popular existir. Há uma multiplicidade de instituições que se relacionam com as associações comerciais, familiares e a vizinhança; há uma rede de compadrios e de parentesco que subsidiam o mercado de trabalho; há uma rede de fornecedores, clientes e atravessadores (sacoleiras) que garantem a estabilidade dos negócios, e por fim, existem formas de articulação com 
funcionários da aduana, instituições estatais, que ajudam com os trâmites administrativos do processo de importação (TASSI et al, 2013, p. 161)

A partir da análise de Tassi et al (2013) sobre o comércio popular na Bolívia, pode-se entender que a condição de existência desse tipo de atividade na fronteira depende dessa multiplicidade de instituições, como bem disse:

\begin{abstract}
Estas diferentes institucionalidades y redes si, por un lado, garantizan ciertos niveles de confianza entre diferentes actores - camioneros, comerciantes, provedores -, en contexto donde las instituciones tradicionales no han logrado proveer un marco económico regulador, por el otro lado, generan un entramado de relaciones que funciona como una forma extensa de control y prevención de atividades y prácticas antisociales en el ámbito de la economia informal y de una serie de prácticas ilícitas. El capital social, en el contexto del comercio popular, cumple una función bastante más extensa y compleja de la de simple "lubricante" del sistema económico; con sus redes y estructuras, parece definir el "como" y el "hacia donde" este tipo de economia se expande (TASSI $e t$ al, 2013, p. 161).
\end{abstract}

Sendo assim, ao longo de seis anos, foi possível registrar os novos empreendimentos que surgiram ao redor da linha de fronteira cujas atividades complementam o comércio popular, tais como: hotéis, restaurantes, supermercado, agência bancária, casas de câmbio e também se nota a presença de comerciantes brasileiros. A entrada de brasileiros na atividade comercial na fronteira boliviana ocorre mediante a capitalização das "cassetas" (boxes) do Centro Comercial 12 de Octubre com valores que variam entre cinco mil dólares e a trinta mil dólares (conforme dados coletados a partir das entrevistas realizadas em setembro de 2014) ${ }^{54}$. Esse montante é utilizado pelos comerciantes bolivianos para conseguir financiamento bancário para realizar novos investimentos.

É visível o crescimento de prédios e melhorias na infraestrutura urbana ao redor da linha de fronteira, as imagens abaixo foram realizadas na Calle 21 de Septiembre que fica na linha da fronteira. A primeira imagem retratada em agosto de 2008 revelou a área destinada ao estacionamento de ônibus e vans sem cobertura e muito terrenos vazios ao redor, onde a circulação ficava restrita apenas à população local.

Ainda nessa fase, é possível dizer que o processo de expansão do comércio popular na fronteira teve como incentivo a cooperação financeira entre familiares e

\footnotetext{
${ }^{54}$ M.V.. Entrevista XXVI [set. 2014]. Entrevistadora: Dirce Sizuko Soken. Puerto Quijarro, 2014. 1 arquivo $\mathrm{mp} 3$ (60 $\mathrm{min}$.).
} 
amigos, conhecida como Pasanako ${ }^{55}$, funciona como um sistema informal de capitalização financeira, por meio do qual onde a relação de confiança entre cooperados e organizador depende de depósitos mensais realizados por cada participante, daí formase o montante que é sacado por um participante de cada vez mediante a realização de lance. Esses comerciantes de posse do montante obtido pelo sistema financeiro informal realizam grandes compras de mercadorias e/ou investem em novas propriedades comerciais e residenciais aqui na linha da fronteira ou em Santa Cruz de la Sierra.

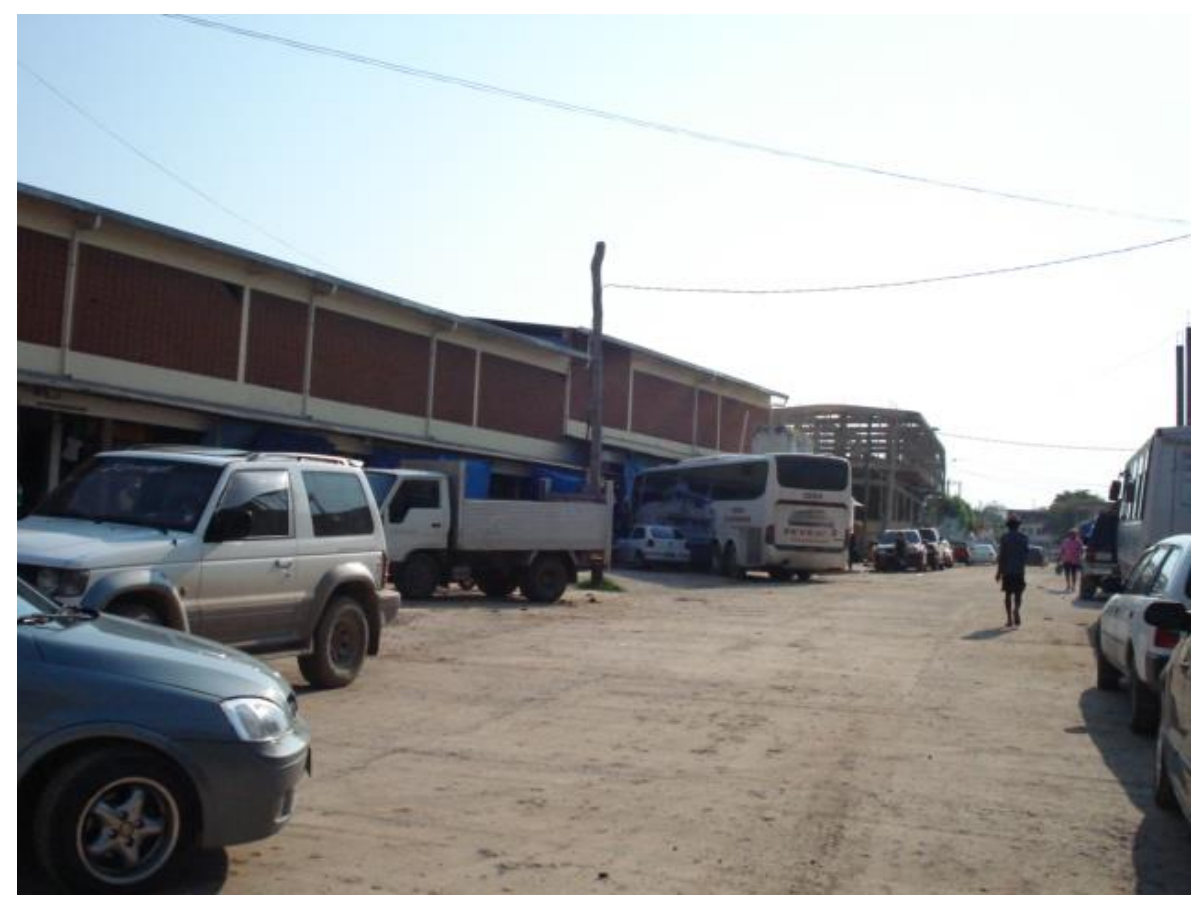

FOTO 6 - Bolívia, Arroyo Concepción em Puerto Quijarro, lado esquerdo da Calle 21 de Septiembre, principal centro comercial de produtos populares, fotografado em agosto de 2008 .

Foto: SOKEN, D, agosto de 2008

\footnotetext{
55 Segundo Tassi (2013, p. 162) o pasanako é a principal forma de financiamento utilizado pelos comerciantes, além dos importadores da Zona Franca de Iquique e os produtores chineses que proporcionam formas de empréstimos e facilitam o pagamento.
} 


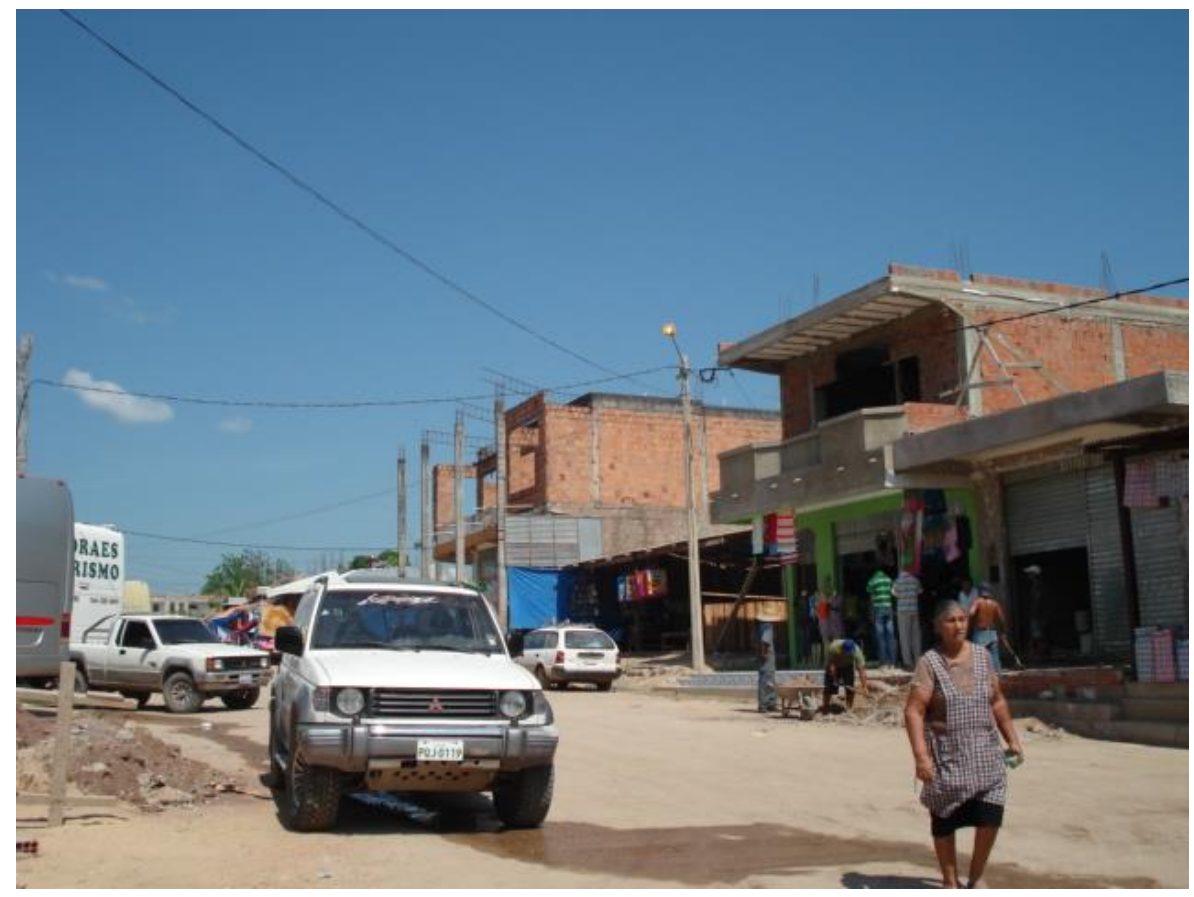

FOTO 7 - Bolívia, Arroyo Concepción em Puerto Quijarro, lado direito da Calle 21 de Septiembre, principal centro comercial de produtos populares, fotografado em agosto de 2008.

Foto: Dirce Soken, agosto de 2008

$\mathrm{Na}$ segunda imagem retratada em setembro de 2014 na mesma localidade constata-se a cobertura do estacionamento para ônibus e vans, os terrenos à frente estão sendo ocupados por novos prédios comerciais, especializados em vestuário que passou a atrair novo fluxo de sacoleiras para este lado da rua.

Percebe-se que a infraestrutura urbana como calçamento e pavimentação de vias de circulação comercial na linha da fronteira segue o fluxo dos negócios, no entanto, em áreas residenciais, ao redor desses estabelecimentos estão desprovidas de elementos urbanos, as condições de saneamento básico, calçamento, pavimentação de ruas, iluminação entre outros encontram-se em situação precária. 


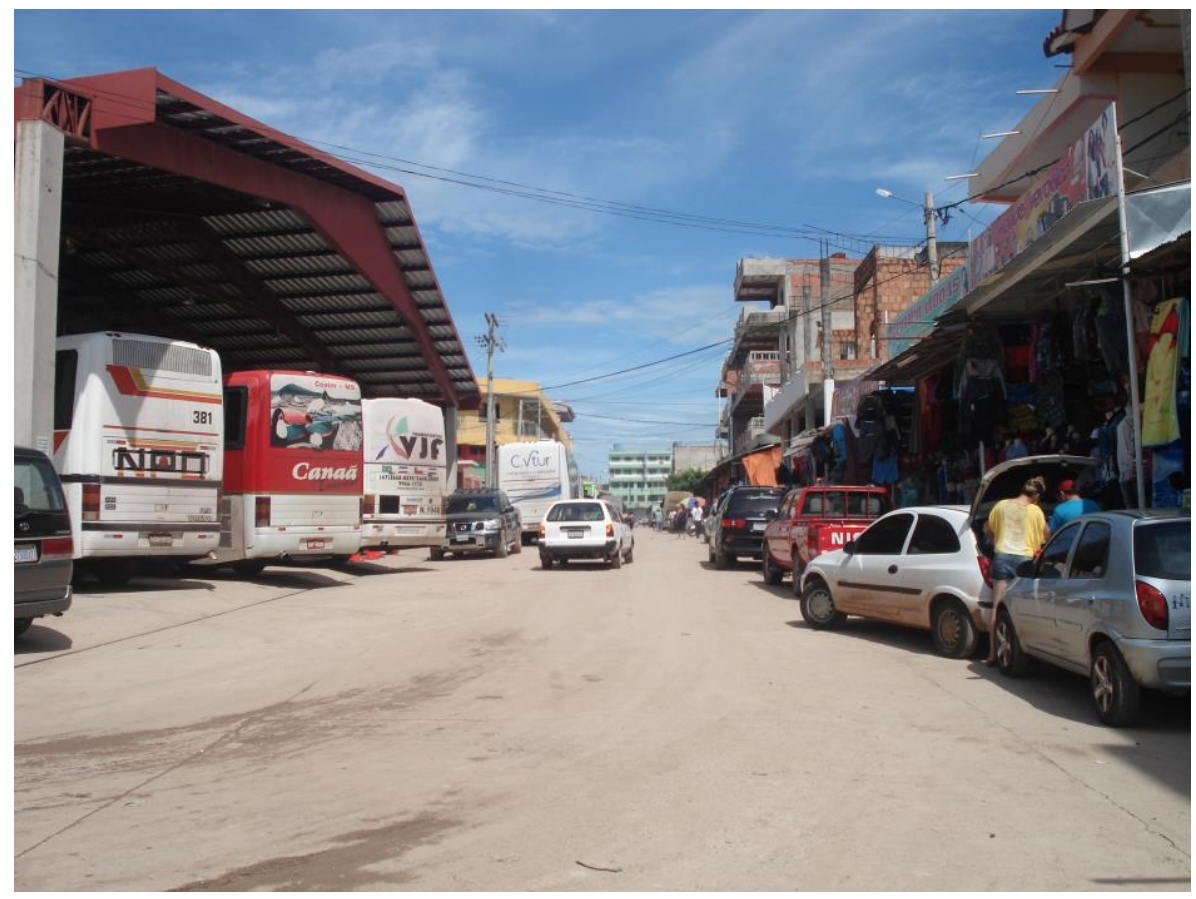

FOTO 8 - Bolívia, Arroyo Concepción em Puerto Quijarro, Calle 21 de Septiembre, principal centro comercial de produtos populares, fotografado em setembro de 2014.

Foto: SOKEN, D, setembro de 2014

Outro elemento de financiamento do comércio popular da fronteira é o uso de várias moedas. Neste espaço fronteiriço a circulação de mais de uma moeda torna-se uma necessidade vital para os negócios, pois, as variações cambiais do mercado de moeda local favorecem a manutenção dos preços dos produtos em concorrência aos mercados mais competitivos.

No caso do comércio do lado boliviano, o uso das três moedas Real (R\$), Dólar (US\$) e Boliviano (Bs\$) é necessário para as transações diárias nesta fronteira. Compõe um dos elementos utilizados pelas mulheres comerciantes para suprir a carência de capital de giro. Considerada a forma de financiamento mais comum, as comerciantes bolivianas recebem moeda brasileira $(\mathrm{R} \$)$ ao venderem suas mercadorias para os brasileiros, em contrapartida realizam pagamentos aos fornecedores com moeda boliviana (Bs\$) que é três vezes menos valorizado ${ }^{56}$ que o Real. E pelo fato de moeda americana (US\$) ${ }^{57}$ circular mais intensivamente no comércio de importação, sua apreciação resulta em maior fluidez do que as moedas correntes nestas localidades, tanto de Reais como de Bolivianos, e que por sua vez, eleva o poder de barganha das comerciantes do comércio popular.

\footnotetext{
${ }^{56}$ A taxa de câmbio da moeda boliviana está em R \$ 0,33 conforme consulta ao Banco Central do Brasil em 08/07/2013.

57 A moeda americana está cotada em R \$ 2,26 (reais) e Bs\$ 6,86 (bolivianos), conforme BACEN em 08/07/2013.
} 


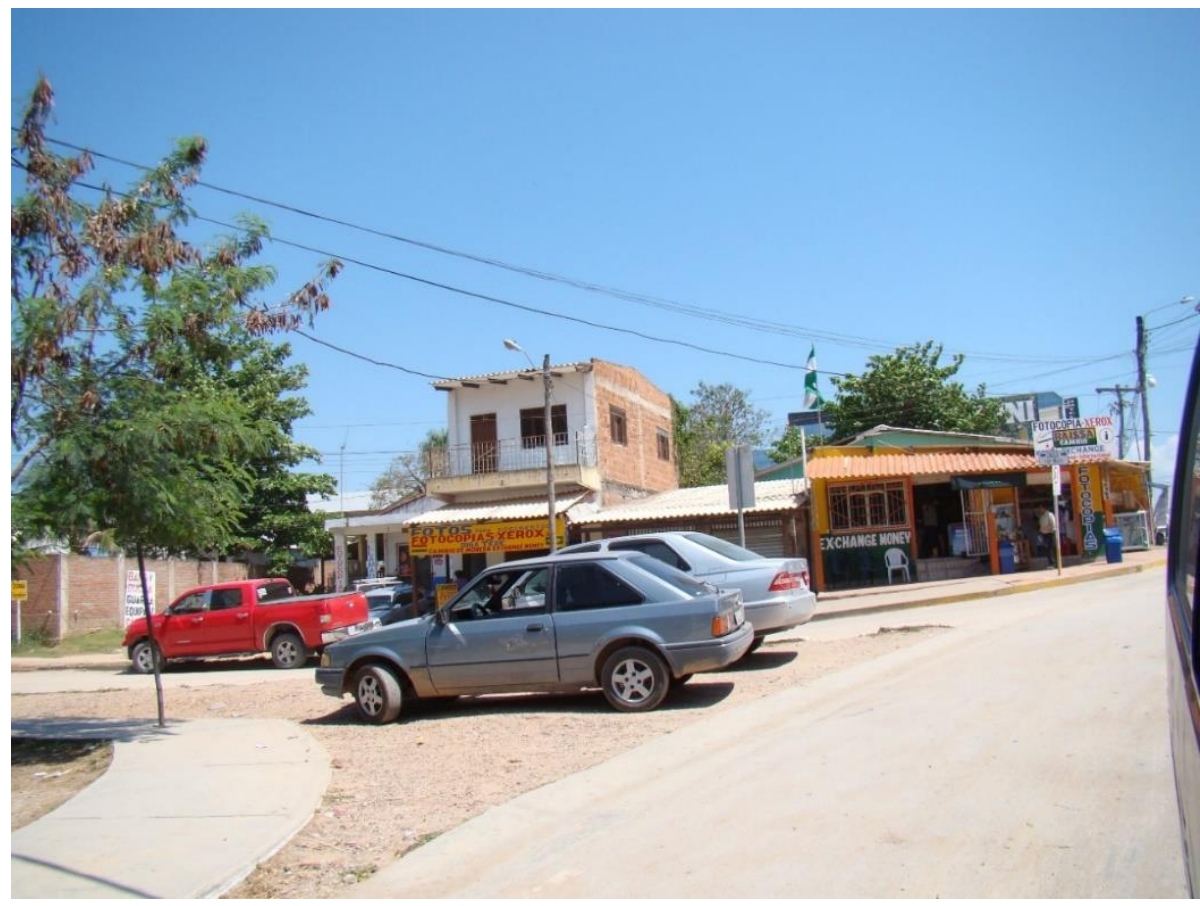

FOTO 9 - Bolívia, Arroyo Concepción em Puerto Quijarro, casas de câmbio na linha de fronteira Foto: SOKEN, D., setembro de 2014

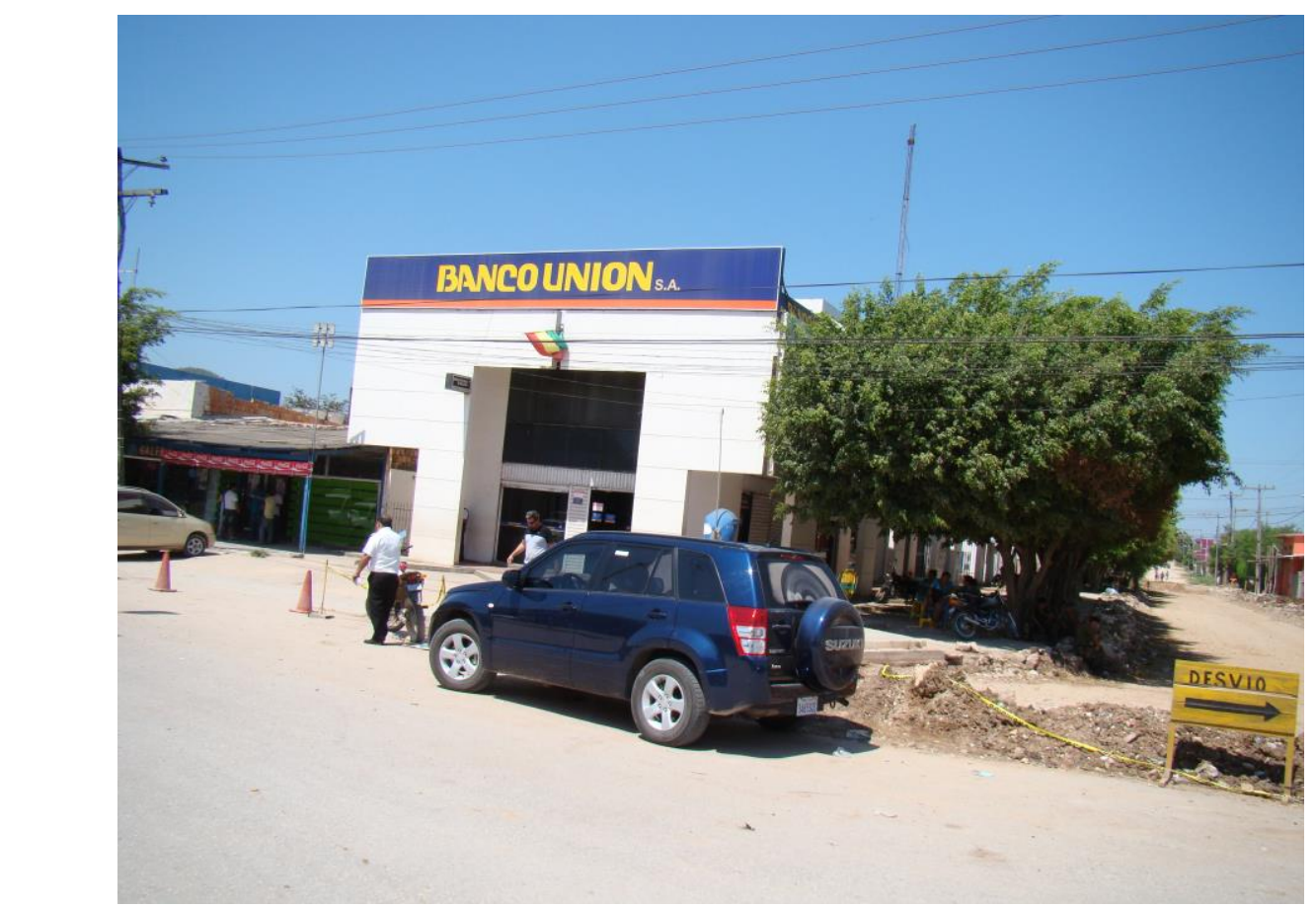

FOTO 10 - Bolívia, Arroyo Concepción em Puerto Quijarro, banco público na linha de fronteira, Ruta Nacional 4

Foto: SOKEN, D., setembro de 2014

Segundo Tassi et al (2013, p. 61), a rede financeira se duplicou no período entre 2007 e 2012. Em 2007 existiam 1.813 pontos de atendimento financeiro na Bolívia e no ano de 2012 esse número subiu para 3.736 pontos espalhados pelo país. O crédito para o 
comércio cresceu a taxas de $49 \%$ em 2010 para 32\% em 2011, bem superior ao setor produtivo, sendo que a indústria manufatureira e a construção civil chegaram a $14 \% \mathrm{em}$ 2011 e as atividades de serviços, como transporte, armazéns e comunicação não passaram de $9 \%$.

A relação entre a instituição bancária e o comércio popular é um tanto curiosa. $\mathrm{O}$ comerciante utiliza os serviços bancários apenas para algumas situações, tais como: manter uma conta corrente para que os clientes façam pagamento da mercadoria recebida. Após o pagamento, costuma-se sacar o dinheiro da conta para guardar em outro lugar. Os comerciantes realizam empréstimos bancários sem precisar abrir uma conta e convertem esse montante em novas mercadorias (TASSI et al, 2013, p. 163)

A presença de várias instituições financeiras na linha da fronteira é significativa, entre elas se destacam, o Banco Unión, o Banco Bisa, Banco Sol, a Cooperativa Jesus Nazareno, entre outras. A tomada de empréstimos é facilitada para os comerciantes da fronteira, cuja avaliação se faz in loco onde se analisa o tamanho do estabelecimento, o volume de mercadorias compradas, além disso, é de costume estabelecer um contato pessoal.

É notória a circulação de dinheiro em espécie no comércio popular, tal fato pode ter relação com o tipo de gestão familiar operacionalizado pelo comerciante boliviano. Segundo as observações de Tassi et al (2013, p. 164), é comum o pagamento de pequenas despesas domésticas com o fluxo de caixa, bem como a realização de negócios diariamente que envolvem desde pequenos valores a grande quantidade de dinheiro.

Com base no conjunto de informação coletado pela pesquisa, observa-se que na fronteira o comerciante boliviano se apropria de certa margem de lucro mediante a conversão de produtos populares em outros negócios, tais como, carros e motos, mercadorias de alta liquidez, além disso, utiliza os preços das moedas de circulação local para barganhar nas transações comerciais.

Tal situação é recorrente na fronteira, há sempre uma mescla entre os negócios familiares com o fluxo de caixa dos produtos populares que provêm tanto os investimentos quanto os gastos com a reprodução da família. Alguns comerciantes investem em bens imóveis na fronteira ou nas cidades do interior da Bolívia, 
principalmente em Santa Cruz de la Sierra, outros na educação dos filhos com pagamento de mensalidades da escola/faculdade que ficam na cidade de Santa Cruz.

Quanto à decisão em investir em imóveis há que se considerar a localização comercial e a funcionalidade desse empreendimento, que possa servir além de residência, mas também de alojamento de trabalhadores ou de depósito de mercadorias ou salão de festa, segundo Tassi et al (2013, p. 180) ${ }^{58}$ esta é uma prática conhecida entre os comerciantes de sucesso em El Alto, La Paz.

Sendo assim, a expansão do comércio popular depende da amplitude da rede social familiar, no caso de um comerciante solteiro precisa de uma esposa e filhos para conseguir diversificar o negócio e poder se deslocar para outros mercados; depende da rede social criada pelos parentes (irmãos, tios, cunhados) para facilitar o acesso a novos mercados e também para conseguir reduzir custos ao realizar compras em cooperação.

Outra forma de financiamento do comércio popular trata-se de empréstimos ou pagamento a prazo, concedidos pelos importadores. Isso de certa forma coloca alguns desses comerciantes bolivianos em contato com o mercado mais competitivo, cuja mercadoria adquirida tem baixo custo e alta rotatividade (TASSI et al, 2013, p. 172).

Pode-se afirmar então, que o comércio popular na Bolívia é um negócio rentável, por possuir uma dinâmica variável e facilmente adaptável às oportunidades e risco do mercado global. Conforme analisa Tassi et al (2013, p. 179): si hay una práctica consistente y recurrente en los patrones de rebalse del comercio y de reinversión, es la tendência a reinvertir en el país, evitando guardar sus ahorros em bancos extranjeros e identificando posibilidades locales de negócio.

Além disso, é interesse dos comerciantes populares se passarem por invisíveis ou até mesmo serem considerados de um setor marginal, porque assim não sofrem interferências em suas institucionalidades e muito menos se deixam subordinar à classe dominante e exploradora (TASSI et al, 2013, p. 122).

\footnotetext{
58 Segundo pesquisa de Tassi et al (2013, p.180) revela que comerciantes alteños-paceños estão construindo prédios plurifuncionais - moradia e comércio - na fronteira entre Cobija e o Acre. Recentemente o governo tem oferecido terras agrícolas para conter a entrada de colonos brasileiros pela fronteira, isso tem aquecido o mercado de casas ao redor da cidade.
} 
Percebe-se que a ordem global por meio do comércio de importação e exportação organiza o espaço de fronteira, uma vez que encontra forma de conectar o processo de acumulação de mais-valia local ao funcionamento da economia mundial, no entendimento de Milton Santos (2006, p. 284) é denominada de verticalidade, enquanto que a outra partição do espaço denominada de horizontalidade é determinada pelas redes familiares de ambas as localidades fronteiriças.

Cabe aqui mencionar uma passagem da obra "A Natureza do Espaço" de Milton Santos que revela a recente dinâmica territorial da fronteira entre Brasil e Bolívia sob a luz da verticalidade do espaço:

\begin{abstract}
A verticalidade cria interdependências, tanto mais numerosas e atuantes quanto maiores as necessidades de cooperação entre lugares. Assim como nos diz Gilles Paché (1990, p. 91), nessa "nova geografia dos fluxos dos produtos" cria-se "um sistema de produção reticular" (résillaire), a partir de suportes territoriais largamente redistribuídos, que asseguram a coesão do processo produtivo (SANTOS, 2006, p. 285).
\end{abstract}

A verticalidade de que trata Santos impõe "novas formas de solidariedade entre os lugares", pensado por meio dos arranjos organizacionais que impõem nova racionalidade de origem distantes aos lugares e regiões, portanto, são definidores de sua existência (SANTOS, 2006, p. 285). Sendo assim, o espaço transfronteiriço só pode ser entendido pela sua funcionalidade no sistema produtivo e reprodutivo do capital, representa um ponto de intersecção entre verticalidades e horizontalidades e, portanto, produzem um "arranjo territorial” que articula a circulação de produtos e pessoas.

Desta forma, o segundo capítulo tem como propósito discutir a nova inserção produtiva e comercial da Bolívia a partir do setor têxtil e confecção, nos países da Comunidade Andina e, principalmente, evidenciar o estreitamente das relações produtivas e comerciais entre China e Bolívia. Para isso, será realizada primeiramente uma contextualização do processo de reestruturação produtiva mundial do setor têxtil e de confecção e, posteriormente far-se-á uma análise de seus impactos no mercado de trabalho feminino.

Por fim, publicita-se as imagens abaixo com o propósito de evidenciar o crescimento das atividades na linha de fronteira. A rodovia boliviana Ruta Nacional 4 que dá acesso às cidades fronteiriças bolivianas liga a cidade de Corumbá, esse trajeto de $1 \mathrm{~km}$ era ocupado apenas por algumas atividades de serviço, tais como: casas de câmbio, 
lanchonetes e agências bolivianas de transporte intermunicipal. Atualmente, recebe dezenas de construções ao longo da linha de fronteira, se especializando em atividades de serviço como hospedagem, alimentação, transporte e serviços financeiros.

Observa-se que a primeira imagem foi retratada em agosto de 2008, com sentido do fluxo das cidades bolivianas de fronteira para a cidade de Corumbá. A segunda imagem foi retratada em setembro de 2014 com sentido Corumbá para as cidades bolivianas, nota-se uma imensa placa indicando o "Estado Plurinacional de Bolívia" e os principais caminhos de circulação a partir deste 'espaço' de fronteira, a primeira indicação da esquerda para a direita da placa direciona para Zoframag $(6 \mathrm{~km})$; Mutun (42km), Puerto Busch $(155 \mathrm{~km})$. Ao centro indica para Puerto Suarez $(11 \mathrm{~km})$, San Jose $(387 \mathrm{~km})$, Santa Cruz $(594 \mathrm{~km})$. À direita da placa, há indicação do sentido para Arroyo Concepción, Puerto Quijarrro e Puerto Aguirre. 


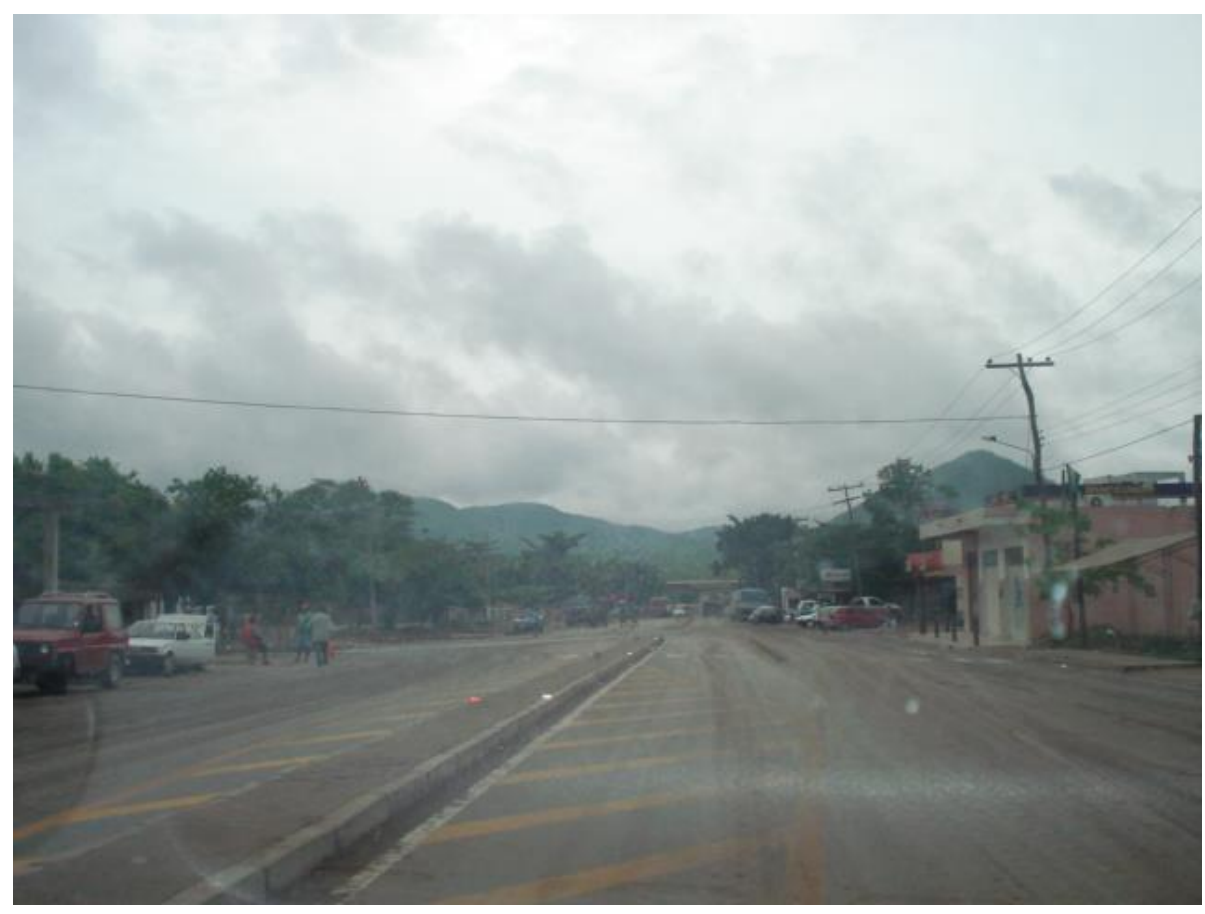

FOTO 11 - Bolívia, Arroyo Concepción em Puerto Quijarro, Ruta Nacional 4, principal rodovia de acesso a Santa Cruz de la Sierra e a cidade de Corumbá/Brasil, fotografado em agosto de 2008.

Foto: SOKEN, D., agosto de 2008

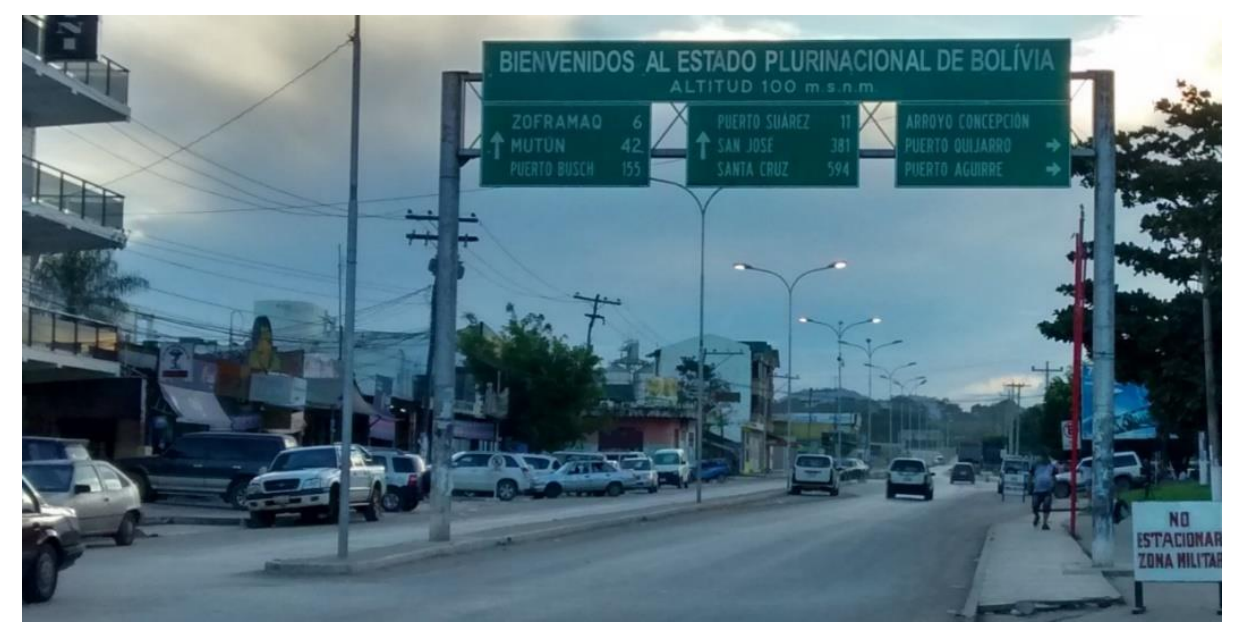

FOTO 12 - Bolívia, Arroyo Concepción em Puerto Quijarro, Ruta Nacional 4, principal rodovia de acesso a Santa Cruz de la Sierra e a cidade de Corumbá/Brasil, fotografado em setembro de 2014.

Foto: SOKEN, D., setembro de 2014 

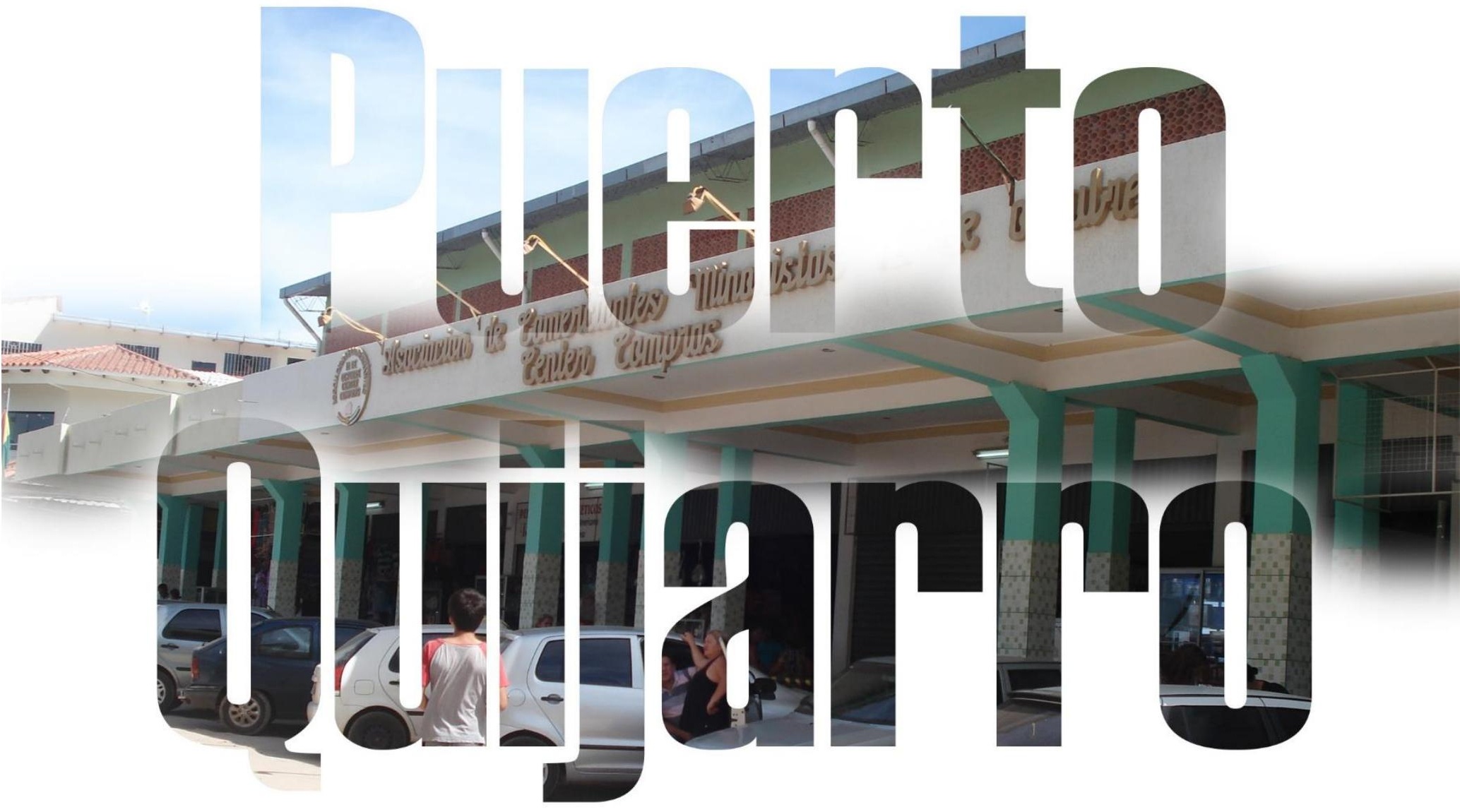

CAPÍTULO 2

TRABALHO FEMININO E FLEXIBILIDADE 
As questões do trabalho feminino são interpretadas a partir do processo de urbanização $^{59}$ que atingiu os países subdesenvolvidos no século XX e cujos impactos sobre a população feminina deram-se pelas esferas da produção e reprodução social, principalmente pelo aumento da mão de obra feminina em atividades urbanas mal remuneradas e de pouca qualificação profissional.

Considerando a mudança tecnológica e as recentes transformações no mundo do trabalho $^{60}$, o debate entre o trabalho feminino e as novas tecnologias, ressalta-se a contribuição da mulher no processo de produção e organização do trabalho. Subsequentemente, as mulheres passaram a participar do mercado de trabalho tendo como motivo relacionado à sobrevivência da família (BRUSCHINI, 1995; ANTUNES, 2002; KON, 2002; POCHMANN, 2005).

Desta forma, as transformações da dinâmica territorial vigente, ao seguirem se expandindo nos moldes da flexibilização de contratos de trabalho, criam áreas não de empregos e sim de ocupações, o que reduz significativamente o nível de assalariamento, aumentam as atividades informais e elevam o desemprego entre jovens, homens, mulheres e idosos (ROSSINI, 2002).

Com a incorporação do progresso tecnológico pelas grandes indústrias o nível de emprego tende a reduzir, o que resulta em precarização do mercado de trabalho. Eleva-se o número de pessoas desempregadas e excluídas do mercado de bens e serviços necessários à reprodução da vida.

Por conseguinte, o fenômeno do desemprego estrutural e a precarização das condições de trabalho tornam-se cada vez mais críticos, pois o novo processo de trabalho que emerge decorrente do modelo flexível de produção gera profundos impactos no mercado de trabalho, resultando em diminuição do operário industrial tradicional e aumento da "classe-que-vive-do-trabalho" (ANTUNES, 2002).

\footnotetext{
${ }^{59}$ SANTOS, M. A urbanização brasileira. São Paulo: Editora Hucitec, 1998.

${ }^{60}$ A recente transformação no mundo do trabalho contextualizado por Antunes (2002) é decorrente da crise estrutural do capital que, após a $2^{\mathrm{a}}$ Guerra Mundial, economias como Alemanha e Japão passaram a aumentar a capacidade da produção mundial e acentuaram a queda da taxa de lucro do sistema capitalista. Esse quadro de crise repercutiu imediatamente nas demais economias desenvolvidas que, em resposta a essa particularidade adotaram novos processos de trabalho onde a esteira e o cronômetro retratado nos modelos fordista e taylorista são substituídos por processos flexíveis de produção. Em decorrência dos avanços da ciência e da técnica vêm propiciando a reestruturação produtiva do universo fabril.
} 
Segundo Antunes (2002), a “classe-que-vive-do-trabalho" é constituída pelo processo de desproletarização do trabalho industrial, fabril e manual; pela terceirização do trabalho com assalariamento no setor de serviços; pela heterogeneização do trabalho com incorporação da força de trabalho feminina no mundo operário e pelo processo de subproletarização do trabalho intensificada pelo trabalho parcial e precário.

Em meio a esse quadro de reestruturação produtiva e organizacional das empresas $^{61}$, proporcionado pela crescente busca de produtividade e ganhos do capital, Pochmann (2005) enfatiza que as mudanças do mercado de trabalho em economias não desenvolvidas sofreram as implicações das estratégias das corporações transnacionais realizadas a partir da década de 1990.

Essas empresas buscam "explorar as oportunidades mais lucrativas de investimentos, abrindo e fechando quantas unidades produtivas forem necessárias", uma vez que a crise dos Estados keynesiano acaba estimulando a flexibilização dos contratos de trabalho e mantendo zonas de baixos salários e de reduzida proteção social ${ }^{62}$.

O impacto dessa reestruturação produtiva já se faz presente nos países da América Latina em setor intensivo em mão de obra, como foi o caso da indústria de confecção, que segundo Fagalde (2004, p. 19),

Na América Latina observa-se que o desenvolvimento de pequenas oficinas que trabalham sob a forma de subcontratação e que geralmente se desenvolvem graças a exploração de mão-de-obra familiar não remunerada. Esta situação se apresenta sobretudo no setor de confecção e de produção de calçados (FAGALDE, 2004, p. 19).

Sabe-se que essas novas tecnologias são poupadoras de mão de obra e ainda quando são transportadas para as economias não desenvolvidas, de acordo com Pochmann (2005), disponibilizam postos de trabalhos não qualificados, enquanto os

\footnotetext{
${ }^{61}$ Antunes (2002) salienta que o atual processo de reestruturação produtiva foi intensificado pelas empresas de capitais transnacionais e monopolistas, enquanto uma necessidade de controle social da produção. Somado ao conjunto desses eventos menciona Mészáros quando se refere à necessidade do capital de responder a dificuldade de consumo do modelo anterior que se intensifica com "lei de tendência decrescente do valor de uso das mercadorias" mediante a adoção pelas empresas do que ficou conhecido por "qualidade total", nas palavras de Antunes, "quanto mais qualidade total os produtos devem ter, menos deve ser seu tempo de duração", sendo assim, mantendo a reprodução ampliada do capital.

${ }^{62}$ Em decorrência dessa expansão do processo de reprodução do capital, Antunes (2002) estende sua análise aos países que estão fora do centro do capitalismo avançado composto pela tríade EUA, Alemanha e Japão, que segundo o autor, quanto mais se acirra a competição intercapitalista, mais se incorpora a tecnologia em nível concorrencial e mais se expandem os capitais financeiros dos países da tríade, mais se acentua a "lógica destrutiva do capital" aprofundando o desemprego e as formas de precarização das relações de trabalho nos países subordinados a essa lógica.
} 
países de maior renda concentram os postos de trabalho mais qualificados. Para o autor, isso ocorre em razão da "polarização entre a produção de manufatura, em parte dos países semiperiféricos, e a produção de bens industriais de informação e comunicação sofisticados e de serviços de apoio à produção gerada no centro do capitalismo" (POCHAMANN, 2005, p.34).

A atual reestruturação produtiva leva a maior exclusão da mulher do mercado de trabalho formal, pois, enfatiza Rossini, o emprego formal está sendo substituído pela ocupação; há uma "tônica" que passa pelo mercado informal de trabalho e a terceirização e, considera que:

(...) as mudanças no perfil da pessoa trabalhadora requisitada pelo mercado poderiam, eventualmente, estar favorecendo a demanda por mulheres, à medida que abre espaço para um perfil de trabalho mais flexível, mais intermitente, marcado por jornadas mais curtas e, claramente, mais terceirizado (ROSSINI, 2002).

A fim de observar essa dinâmica imposta pelo novo padrão de acumulação capitalista, são incorporadas nessa análise características pertencentes aos dois países, Brasil e Bolívia, quanto às transformações das condições e à natureza do trabalho feminino.

Para tanto, a seção seguinte apresenta as relações estruturais da força de trabalho feminina do Brasil e da Bolívia. Terá como aporte teórico a dimensão sexuada nas relações do trabalho cuja finalidade é explicar a discriminação e a hierarquização da mulher no mercado de trabalho (BLAY, 1978; BRUSCHINI e ROSEMBERG, 1982; ROSSINI, 1988; KERGOAT, 1989; HIRATA, 2002; MELO e CASTILHO, 2007).

\subsection{A problemática da divisão sexual do trabalho}

Entende-se que o gênero é uma categoria analítica relacional, refere-se à organização social entre os sexos (SCOTT, 1990; BRUSCHINI, 1995; KON, 2002). O conceito de gênero opõe-se ao determinismo biológico ${ }^{63}$ nas relações entre os sexos e recebe um caráter fundamentalmente social, uma vez que o "gênero deve ser visto como

\footnotetext{
63 “As ciências biológicas são herdeiras da antiga tradição filosófica grega que considerava que nascer mulher era uma punição dos deuses e que o único destino dos seres femininos era procriar. Essa percepção levou que as ciências se desenvolvessem baseadas no princípio da inferioridade feminina, escamoteando que durante séculos as mulheres acumularam experiências e aprendizado na arte de curar e na obstetrícia" (MELO e CASTILHO, 2007, p.437 ).
} 
elemento constitutivo das relações sociais, baseadas em diferenças percebidas entre os sexos, e como sendo um modo básico de significar relações de poder” (KON, 2002, p.5).

Como bem define Hirata e Kergoat (2008),

\begin{abstract}
A divisão sexual do trabalho é a forma de divisão do trabalho social decorrente das relações entre os sexos; mais do que isso, é um fator prioritário para a sobrevivência da relação social entre os sexos. Essa forma é modulada histórica e societalmente. Tem como características a designação prioritária dos homens à esfera produtiva e das mulheres à esfera reprodutiva e, simultaneamente, a apropriação pelos homens das funções com maior valor social adicionado (políticos, religiosos, militares, etc.) (HIRATA E KERGOAT, 2008, p.266).
\end{abstract}

Quando o mercado de trabalho incorpora o conceito de divisão sexual do trabalho, Bruschini e Rosemberg (1982, p. 10) nos revelam importante explicação de Marilena Chauí sobre a ideologia que carrega esse conceito, evidencia que:

a contradição entre a vida doméstica e a vida em família pôde, no caso das mulheres, legitimar a naturalidade do trabalho doméstico como se ele fosse um trabalho para a família e não um trabalho da casa e, portanto, um trabalho que já é social (BRUSCHINI e ROSEMBERG, 1982, p. 10).

Portanto, para Bruschini e Rosemberg (1982, p. 10) a tendência à naturalização do trabalho feminino pelo papel de "esposa e mãe" à de "casa e família", naturaliza também a divisão sexual do trabalho. Explicam aquelas autoras que a "casa" sempre foi o lugar da reprodução social, pois anterior à Revolução Industrial, ocorrida na Europa, "a unidade doméstica era uma unidade básica da produção”. Portanto, era responsabilidade de todos da família contribuir para o processo de consumo material da unidade.

Mas, a partir da Revolução Industrial, essa relação do trabalho em "casa" foi fragmentada e substituída pelas relações de mercado onde apenas o trabalho realizado na unidade fabril era remunerado, portanto trabalho produtivo, o qual foi realizado inicialmente pelos homens. Tal fato criou uma hierarquia na relação de valor, o que deixou a mulher numa condição de subvalorização no processo de produção social, se especializando na reprodução da força de trabalho sem remuneração. Surge assim, o conceito não naturalizante da divisão sexual do trabalho (BRUSCHINI e ROSEMBERG, 1982, p. 10; KERGOAT, 1989, p. 90).

Sendo assim, Bruschini e Rosemberg (1982, p. 11 e 12) ressaltam que é preciso rever o conceito de trabalho para melhor compreender a participação da mulher no processo de produção social. Devem ser incluídas nesse conceito as atividades que 
produzem valor de uso nas unidades domésticas, oficialmente reconhecido pelas estatísticas como trabalho não produtivo.

Para Bruschini e Rosemberg (1982, p. 11 e 12) as estatísticas oficiais não abrangem a totalidade do trabalho feminino, pois a que se considerar que o trabalho não remunerado como é o caso do trabalho doméstico, ou, dependendo da posição que a mulher ocupa na família e a classe social, podem criar condições diferenciadas de inserção no mercado de trabalho.

Como exemplo, pressupõem-se duas situações: a) a primeira quando a mulher é solteira e sem filhos terá maior chance de aumentar a renda familiar. Já para uma casada com filhos, além de ter que enfrentar as restrições do mercado de trabalho, tem de dar conta das atividades domésticas; b) outra situação depende da posição social da família, uma mulher de família abastada terá condições de ir ao mercado de trabalho com as obrigações domésticas asseguradas por terceiros; já a de família de baixa renda é mais conveniente se manter com os afazeres domésticos e encaminhar tão prontamente os filhos ao mercado de trabalho (BRUSCHINI e ROSEMBERG, 1982, p. 11 e 12).

A partir de uma perspectiva histórica sobre as atividades das mulheres, Delphine Gardey (2003, p.37), menciona Michelle Perrot que descreve algumas das atividades que ficaram a sombra do trabalho assalariado, no entanto são essenciais para o desenvolvimento da sociedade industrial, tais como a empregada doméstica, as comerciantes, as campesinas e as donas de casa.

A relação de gênero como categoria analítica nos revela as transformações socioespaciais. Portanto, segundo Maruani (2008):

A atividade feminina é, ao mesmo tempo, uma realidade econômica e uma construção social. Um "fato social total". As flutuações do emprego feminino e os movimentos da divisão sexual do trabalho nos informam sobre o estado de uma sociedade: o funcionamento do mercado do emprego, o lugar do trabalho no sistema de valores, o estatuto do segundo sexo e as relações entre homens e mulheres (MARUANI, 2008, p.36).

E conforme Hirata e Kergoat (2008, p.111), enquanto a conciliação entre "vida profissional" e "vida familiar" for pertinente à mulher, haverá a divisão sexual do trabalho. Esta só atingirá um novo regime de divisão do trabalho entre os sexos se houver mudanças na divisão sexual do saber e do poder entre os sexos. Enfim, entende-se o trabalho feminino, como uma categoria de análise, capaz de nos revelar as desigualdades 
existentes na sociedade capitalista. Parafraseando Maruani (2008, p.36), o trabalho feminino é um fio condutor para descobrir o lugar das mulheres em todas as sociedades contemporâneas.

Para Melo e Castilho (2007, p.5) o conceito Divisão Sexual do Trabalho usado desde o período da industrialização tornou o trabalho da mulher invisível e desvalorizado, pois a "produção" virou "produção de mercadorias" e "trabalho" virou sinônimo de "emprego". Logo, como a atividade industrial era predominantemente masculina deu-se a associação entre o trabalho produtivo é masculino e o trabalho doméstico é o nãotrabalho.

Com base na análise de Kergoat (1989, p.92) a respeito da qualificação de operárias na França na década de 1980, constatou-se que a natureza das tarefas e o ritmo de trabalho eram distintos entre os sexos. Foi revelado que o posto de trabalho feminino era a linha de montagem, tal operação exige repetições, com deslocamento automatizado de um produto ou uma peça, cadência automática de uma máquina e tem remuneração vinculada ao ritmo do trabalho. Tais funções eram relacionadas à natureza do trabalho doméstico considerado uma qualidade (destreza, minúcia, rapidez, etc) legítima das mulheres, portanto, não havia necessidade de se investir em qualificações.

Assim, argumentou Kergoat (1989) a respeito do raciocínio sobre a desigualdade e a conscientização da categoria gênero:

\begin{abstract}
em vez de dizer que as mulheres operárias têm uma formação nula ou mal adaptada, dizemos ao contrário que elas têm uma formação perfeitamente adaptada ao tipo de empregos industriais que lhes são propostos, formação adquirida de início por um aprendizado (a "profissão" de futuras mulheres quando eram meninas) e em seguida por uma "formação contínua (trabalhos domésticos) (KERGOAT, 1989, p.94).
\end{abstract}

A natureza do trabalho feminino é resultado dessa lógica industrial que impõe à mulher uma condição social de reprodução da vida criada pela figura estereotipada de esposa e mãe, o que lhe rende atributos femininos. Percebe-se que tais atributos como: leveza, delicadeza, jornada de trabalho parcial, atenção e cuidados com crianças e idosos, destreza, sensibilidade, entre outros alimentam o debate teórico sobre o trabalho feminino em tempos de acumulação flexível da produção capitalista, discutido nesse capítulo.

Sendo assim, é importante a revisão teórica sobre a ocupação da mulher no mercado de trabalho, uma vez que sua qualificação como força de trabalho depende do 
grau de discriminação do trabalho cujos critérios adotados relacionam os atributos femininos com a produtividade do mercado de trabalho (MELO e CASTILHO, 2007).

Cabe aqui a menção do conceito de "trabalho intelectual" interpretado por Milton Santos, na obra "Espaço e Método", no qual o autor qualifica o trabalho em tempos de globalização. É necessário dizer que a fase mercantilista e industrial do capitalismo impôs novas condições técnicas capazes de unificar o sistema capitalista. No entanto, é no período do meio técnico-científico que se expande e predomina o trabalho intelectual e quando "(...) a ciência, isto é, o conhecimento, se torna uma força produtiva direta" (SANTOS, 2012, p. 54).

Para tanto, isso implica em dizer que novas áreas geográficas são incorporadas ao motor de crescimento da grande indústria, além disso, possibilitam, segundo Santos (2012, p. 44), “(...) a chegada do capital e da tecnologia dos países adiantados para usar uma força de trabalho barata lá onde ela vive, isto é, nos países dependentes" (SANTOS, 2012, p. 44).

\section{$2.2 \mathrm{O}$ circuito espacial têxtil e confecção com uso intensivo mão de obra boliviana.}

Pretende-se nesse subcapítulo apresentar a inserção produtiva da indústria têxtil e de confecção boliviana no mercado mundial, situação que revelou a segmentação da indústria intensiva em mão de obra para localidades de baixo custo de instalação e a concentração da população feminina nas cidades do altiplano boliviano.

Com base nas indicações do produto comercializado na faixa de fronteira constata-se que a indústria boliviana está alinhada ao comércio popular de vestuário de marcas, por exemplo a camisa brasileira de marca (pirata) é resultado das maquilas ${ }^{64}$ que reproduzem tal qual a peça matriz e, no entanto, apresenta falhas no acabamento e tradução da etiqueta.

\footnotetext{
${ }^{64}$ Conforme De La O (2006, p. 406) compreende-se que o modelo de indústria maquiladora surgiu em 1965 e foi parte do Programa de Industrialização Fronteiriça para as cidades da fronteira entre Estados Unidos e México. O objetivo da maquila é produzir manufaturas para exportação com importação de matéria-prima.
} 
É importante dizer que, segundo Fagalde (2004, p. 16) a cultura andina privilegia a organização do trabalho familiar e o trabalho informal da mulher, onde o trabalho é realizado em domicílio podendo ser artesanal ou industrial desde que possibilite à trabalhadora conciliar trabalho produtivo e reprodutivo (doméstico), condição sine qua non das mulheres casadas.

Ainda segundo Fagalde, a incorporação da mão de obra feminina no processo industrial têxtil e de confecção aconteceu em razão da compatibilidade entre a ideologia andina, no que diz respeito à ocupação laboral da mulher, com o processo de flexibilização do trabalho. O que torna necessário controlar horário e adquirir disciplina para coordenar a dupla jornada de trabalho, bem como, se sujeitar a receber o rendimento de acordo com a quantidade produzida, uma vez que também o trabalho é realizado na maioria das vezes com uso da mão de obra familiar.

Segundo relatório sobre o emprego e as condições de trabalho da mundialização da indústria do setor têxtil, vestuário e calçados (tvc), da Organização Internacional do Trabalho - OIT (1996; 2014) e do Banco Nacional do Desenvolvimento - BNDES (2009), ao longo de 20 anos o volume de empregos das indústrias produtoras de tve na Europa e América do Norte tem sofrido redução, enquanto que em países do continente asiático e de países em desenvolvimento essa massa de trabalhadores tende a aumentar.

Para a OIT, esse deslocamento geográfico da indústria tvc é agravado pela queda dos salários e a piora das condições de trabalho, decorrentes da mudança de produção de economia formal para a informal. Portanto, segundo a OIT, o setor informal, especialmente nas indústrias de vestuário e calçado, tem assegurado o crescimento de emprego nas economias dos países em desenvolvimento.

Para a OIT, a demanda das indústrias de tve generalizou a prática do trabalho temporário e em tempo parcial, além disso aumentou o trabalho no domicílio que se realiza em pequenas oficinas cujo salário é pago por peça produzida, ressalta ainda que o trabalho pago por peça é geralmente menor do que o salário pago pela fábrica, considerando-se as mesmas horas trabalhadas.

Segundo os dados da ABIT (2013), mais de $73 \%$ das peças de vestuário exportados no mundo foram fabricadas em países asiáticos, com destaque para China, Índia, Coréia do Sul, Taiwan, Indonésia, Malásia, Tailândia e Bangladesh. 
Conforme consta no relatório da OIT, uma onda de três sucessivas produções transformou a Ásia no principal fornecedor de vestuário do mundo, primeiro atingiu a República da Coréia, Singapura, o território de Hong Kong e Taiwan, posteriormente buscou-se produzir em países do continente asiático onde a mão de obra é mais barata, como Filipinas, Indonésia, Tailândia e Malásia. E por seguinte, entre os anos de 1985 a 1990 Bangladesh, Paquistão e Sri Lanka, e, mais recentemente, Laos, Nepal e Vietnã passaram a liderar o mercado de exportação de vestuário.

A inserção de países periféricos na produção mundial de tvc implicou em mudanças no padrão de concorrência, segundo Gorini (2000, p. 19) surge um novo padrão baseado não somente "em preços, mas também em qualidade, flexibilidade e diferenciação de produtos, além da própria organização do comércio intrablocos", com destaque a "Nafta; União Européia e as regiões do Norte da África e Sul da Ásia, como Índia e Paquistão; Sudeste da Ásia e o Extremo Oriente; Mercosul e América Latina" (GORINI, 2000, p. 19, 20).

As indústrias norte-americanas e europeias resolveram se especializar em demandas voláteis da moda, uma vez que o mercado de produtos básicos representa apenas $20 \%$ das vendas de roupas. No caso do mercado norte-americano as roupas de estação representam $45 \%$ do mercado e os produtos da moda representam $35 \%$, segundo dados de 1998 (GORINI, 2000, p. 20).

Gorini (2000, p. 20) destaca a atuação dos Estados Unidos no Nafta que adotou a estratégia de investir em novas tecnologias, em processos, em venda e no produto, tornando-se capital-intensivo.

por exemplo, os Estados Unidos exportam tecidos pré-cortados e outras matérias-primas para o México, que fica responsável pela confecção e re-exportação para o mercado norte-americano, em condições de acesso privilegiadas. Não obstante, as matérias-primas utilizadas devem ser obrigatoriamente provenientes do Nafta (GORINI, 2000, p. 20).

A reprodução desse sistema denominado de "production-sharing" nos países do Caribe fez ampliar a oferta de fornecedores para o mercado americano. Com destaque para a República Dominicana, Costa Rica, Honduras e El Salvador responsáveis por fornecer $40 \%$ de roupas íntimas para o mercado norte-americano (GORINI, 2000, p. 20). 
Outra estratégia trata-se do "Outward Processing Trade (OPT) que consiste na exportação de tecidos para os países vizinhos, de mão de obra barata, para ser confeccionados e re-exportados com tarifas somente sobre o valor adicionado" (GORINI, 2000, p. 20).

O sistema reproduzido no continente americano possibilita o desenvolvimento de parte da cadeia produtiva do setor de vestuário mediante o sistema de maquilas baseado em baixo custo da mão de obra e importação de insumos. Já o sistema asiático possibilita, além de produzir com coordenação de empresas, prestar serviços com o desenvolvimento do produto, elaboração da matéria-prima, controle de qualidade e da logística (GORINI, 2000, p. 22).

Países em desenvolvimento como a Bolívia, têm pouca participação no mercado de exportação mundial. Em 2013, o setor têxtil participou com 0,009\% e de confecção com $0,005 \%$. E no Brasil, o setor têxtil participou com 0,3\% e 0,035\% do setor de confecção para o mesmo período (OMC, 2013) ${ }^{65}$. Isso implica dizer que os efeitos desse processo de reestruturação produtiva da indústria tvc em países em desenvolvimento ocorreram de forma particular.

Observa-se que a estrutura produtiva boliviana possibilitou a ampliação e verticalização do sistema de maquilas com a coordenação de famílias, comunidades indígenas, associações entre outros grupos. Esse fato explica o aumento das importações de produtos têxteis nos últimos treze anos, as taxas de crescimento que oscilavam entre $2 \%$ a $4 \%$ referente aos anos de 2000 a 2009, a partir do ano de 2010 passaram para $60 \%$ que representaram a soma de US\$69.961.093,00. As taxas continuaram subindo, nos anos seguintes chegam a cifra de US\$ $126.931 .490,33$ de produtos têxteis importados no ano de 2013.

O setor de confecção manteve o saldo da Balança Comercial boliviana positiva entre os anos de 2001 até 2010, cujas taxas de crescimento foram crescentes até o ano de 2004, após esse período sofreu quedas contínuas, as quais resultaram em taxas negativas nos anos de 2011 a 2013 e ampliaram as importações no setor ao todo.

\footnotetext{
${ }^{65}$ Organização Mundial do Comércio. Site:www.sta.wto.org
} 


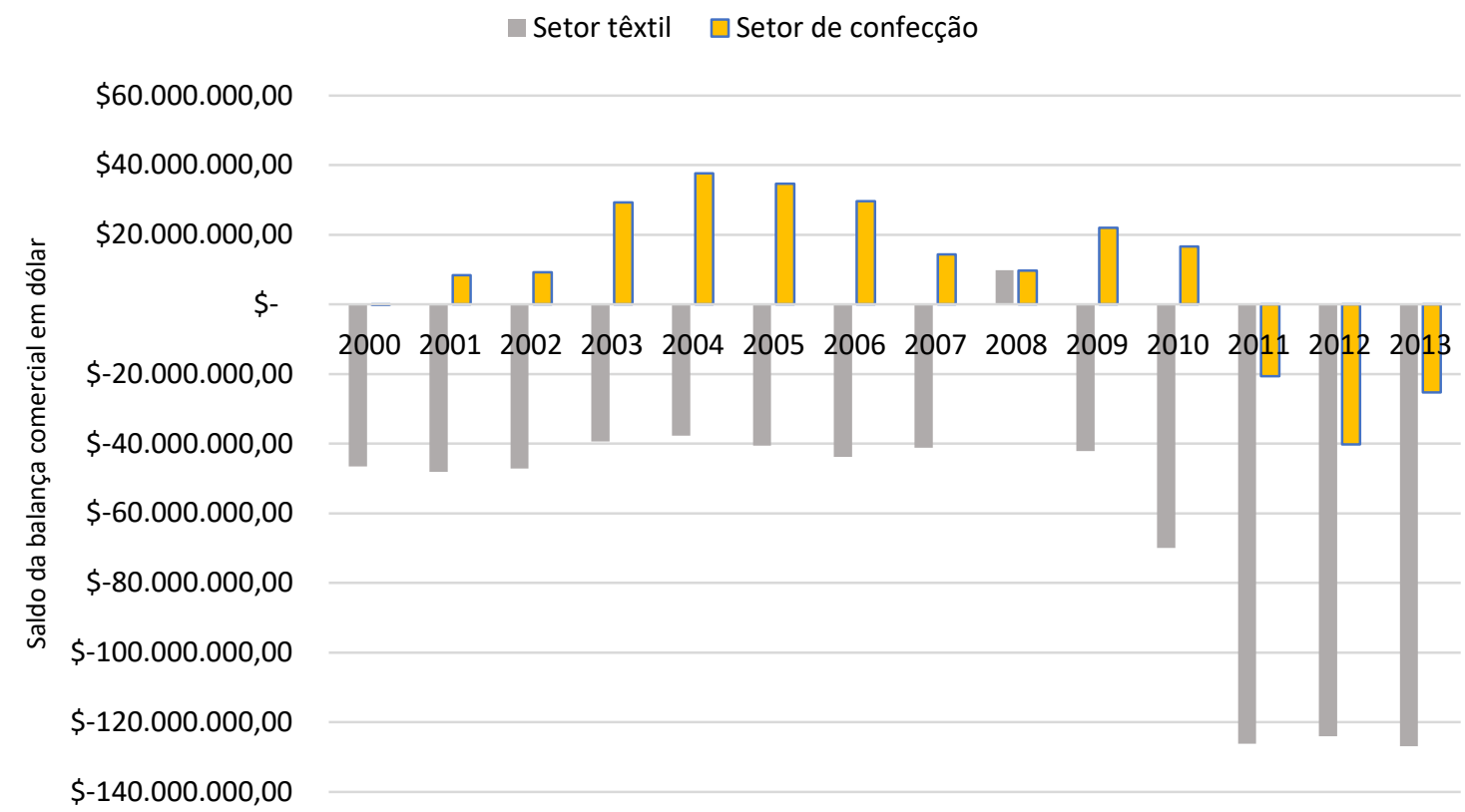

GRÁFICO 5 - Saldos da Balança Comercial da Bolívia do setor Têxtil e de Confecção, segundo valor em dólar, para os anos de 2000 a 2013.

Fonte: INE/Bolívia.

Elaboração: Dirce Soken, 2014

A taxa de crescimento do setor têxtil e de confecção da Bolívia acompanhou o crescimento do PIB boliviano, que é resultado do aumento da produção e do preço do gás natural. No que diz respeito à participação no PIB, a produção têxtil e a confecção bolivianas representam $0,65 \%$ do PIB do país. Já a atividade de exploração e comercialização do gás natural, no momento, a principal atividade econômica da Bolívia, é responsável por 8\% do PIB (INE, 2013).

Verificou-se que ao longo da década de 2000 a participação do setor têxtil e de confecção no PIB estava acima de 1,5\% e foi a partir dos anos de 2002 e 2009 que a queda da taxa de crescimento do setor foi acentuada, caiu de -2,36\% em 2002 e - $-0,88 \%$ em 2009, ficando estável nos próximos anos entre 2010 a 2013 (INE). Observou-se que as exportações para os EUA tiveram contribuição para essa queda, pois entre os anos de 2002 e 2009 houve saldo negativo na balança comercial, sendo a queda puxada pelo setor de têxtil de US\$3.236.935,00 e US\$2.976.432,00 para os respectivos anos. 


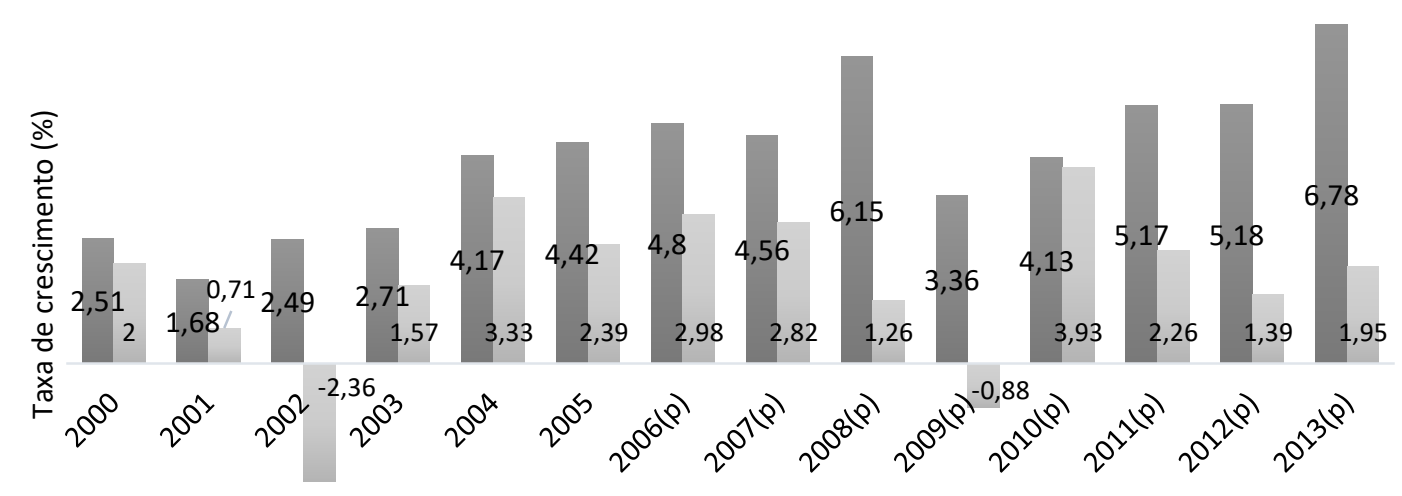

Ano

GRÁFICO 6 - Taxa de crescimento do PIB a preços constantes, segundo atividade econômica, referente aos anos de 2000 a 2013.

Fonte: INE, vários anos.

Elaboração: Dirce Soken, 2014

Sobretudo, o desempenho positivo do setor têxtil e de confecção boliviano foi impulsionado pela entrada de produtos chineses. Os gráficos 07 "Balança Comercial da Bolívia com os principais países, segundo o setor têxtil, no ano de 2013" e 08 "Balança Comercial da Bolívia com os principais países, segundo o setor confecção, no ano de 2013" revelam que os principais países que abastece a Bolívia com produtos têxteis e de confecção são Brasil, China e Peru e inclusive são eles que determinam a estrutura da cadeia produtiva no país, na qual predomina o sistema asiático de produção de baixo custo de mão de obra e fácil acesso às matérias-primas. 


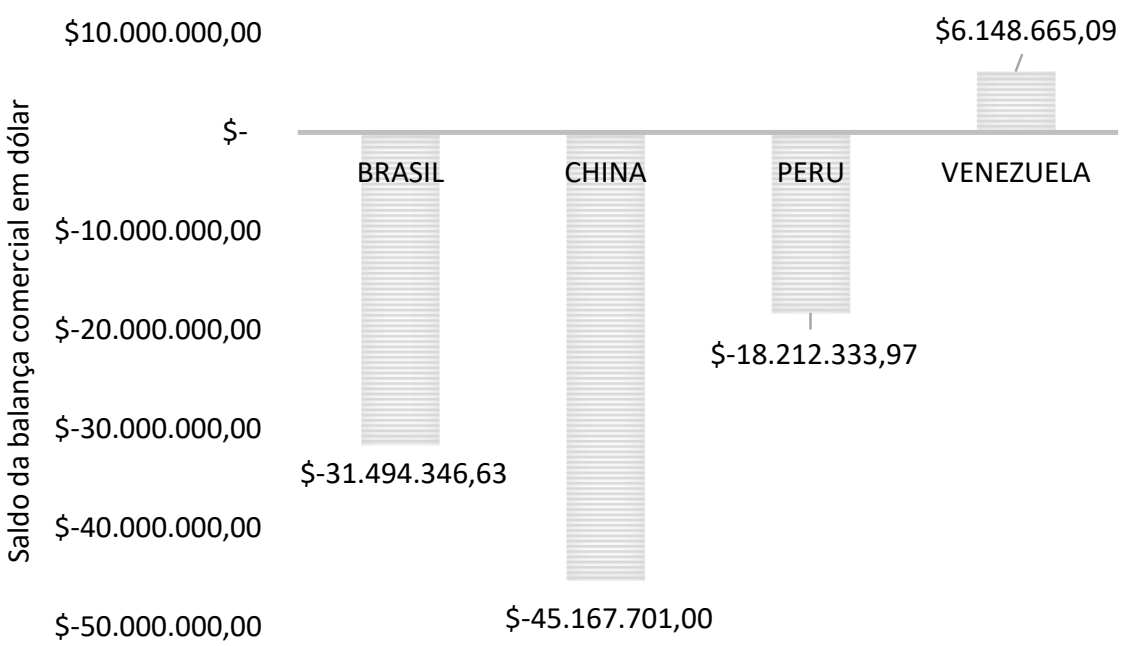

GRÁFICO 7 - Balança Comercial da Bolívia com os principais países, segundo o setor têxtil, no ano de 2013, a preços em moeda americana.

Fonte: INE, Bolívia

Elaboração: Dirce Soken, 2014

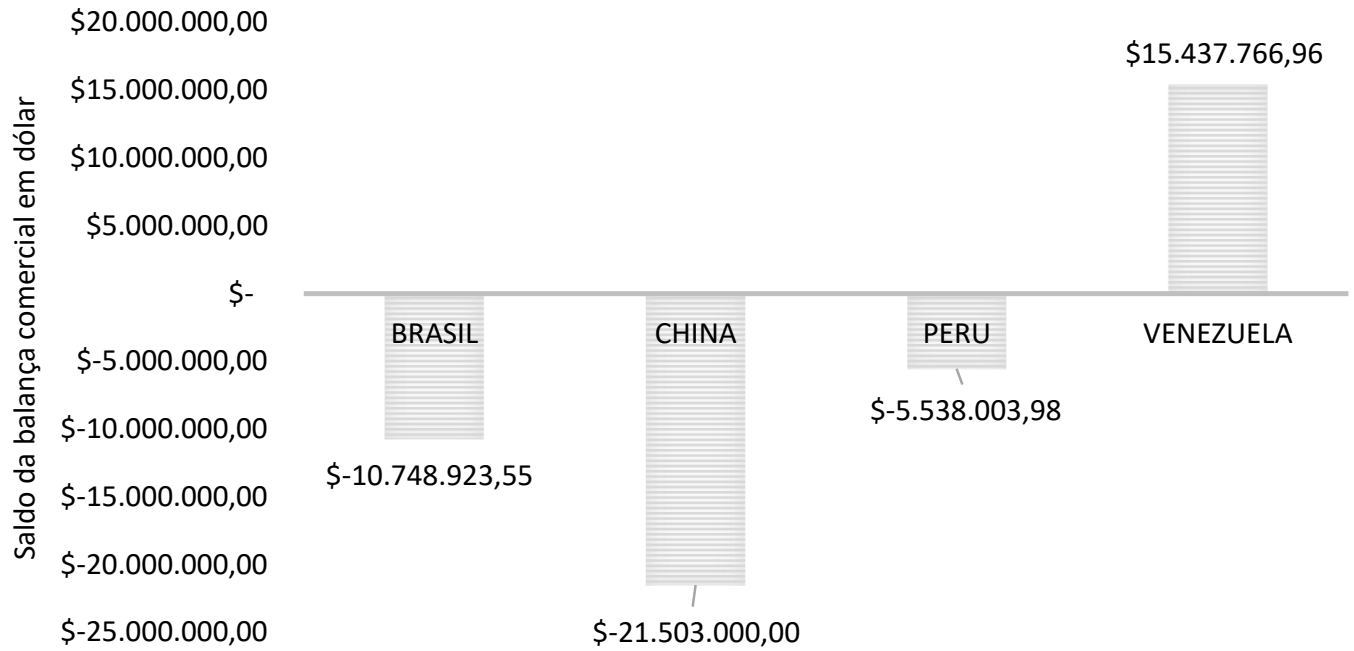

GRÁFICO 8 - Balança Comercial da Bolívia com os principais países, segundo o setor confecção, no ano de 2013, a preços em moeda americana.

Fonte: INE, Bolívia.

Elaboração: Dirce Soken, 2014

É interessante ressaltar que parte do dinamismo do setor do gás natural de certa forma contribuiu para o desenvolvimento do setor têxtil e de confecção no país. Constatase que a partir de 2006 o Governo boliviano retoma a capacidade de investimento no país e incentiva a formação de uma economia popular constituída por núcleos familiares, comunidades indígenas, rurais, associações de pequenos produtores e artesãos com o 
propósito de criar micro e pequenas empresas voltadas para a produção da indústria de confecção (PND, 2006, p.144) ${ }^{66}$.

Por meio de políticas de capacitação profissional o governo boliviano com financiamento do Banco Mundial pretende oferecer aos jovens de 18 a 24 anos trabalho no setor têxtil e de confecção em localidades como La Paz, mais especificamente no distrito de El Alto, Cochabamba, Santa Cruz, Tarija e Potosí. Essa estratégia contribui para organizar a cadeia produtiva do setor têxtil e de confecção.

\begin{tabular}{l|r|r|r}
\hline \multirow{2}{*}{ Cidades } & \multicolumn{3}{c}{ Jovens de 18 a 24 anos } \\
\cline { 2 - 4 } & Homens & Mulheres & Total \\
\hline Cochabamba & 127 & 143 & 270 \\
\hline El Alto & 166 & 254 & 420 \\
\hline La Paz & 7 & 22 & 29 \\
\hline Potosí & 146 & 153 & 299 \\
\hline Santa Cruz de La Sierra & 52 & 38 & 90 \\
\hline Tarija & 71 & 158 & 229 \\
\hline Total & 569 & 768 & 1337 \\
\hline
\end{tabular}

TABELA 5 - Capacitação de jovens para trabalhar no setor de têxtil e confecção da Bolívia, dados de 2013.

Fonte: www.miprimerempleodigno.gob.bo

Elaboração: SOKEN, D., 2013

Por seguinte, é notório que o estreitamento das relações comerciais entre a Bolívia com a Comunidade Andina de Nações (CAN), formada por Colômbia, Peru, Ecuador, Venezuela e a própria Bolívia tem propiciado expansão do comércio boliviano, bem como, amenizado as crises dos países industrializados ${ }^{67}$.

Até meados dos anos 2000, a produção de confecção da Bolívia se destinava para o mercado americano, quando atingiu seu ápice em 2004 com o saldo comercial de US\$ 38.094.303,00. Após esse período as reduções desse mercado tornaram-se cada vez maiores chegando a ser deficitárias em 2013. Todavia, em 2009, a Bolívia encontrou no mercado venezuelano saldo comercial positivo, em 2010 atingiu o máximo de US\$ $32.157 .454,00$

${ }^{66}$ BOLÍVIA. Plan Nacional de Desarrollo de Bolívia. 2006.

${ }^{67}$ A cooperação Sul-Sul regional 
A China, num movimento contrário, puxou o saldo comercial boliviano para baixo com a entrada em massa de produtos de confecção. Em 2012 atinge o maior saldo negativo de US\$46.496.836,00 inundando o setor com $85.554 .706 \mathrm{~kg}$ de produtos.

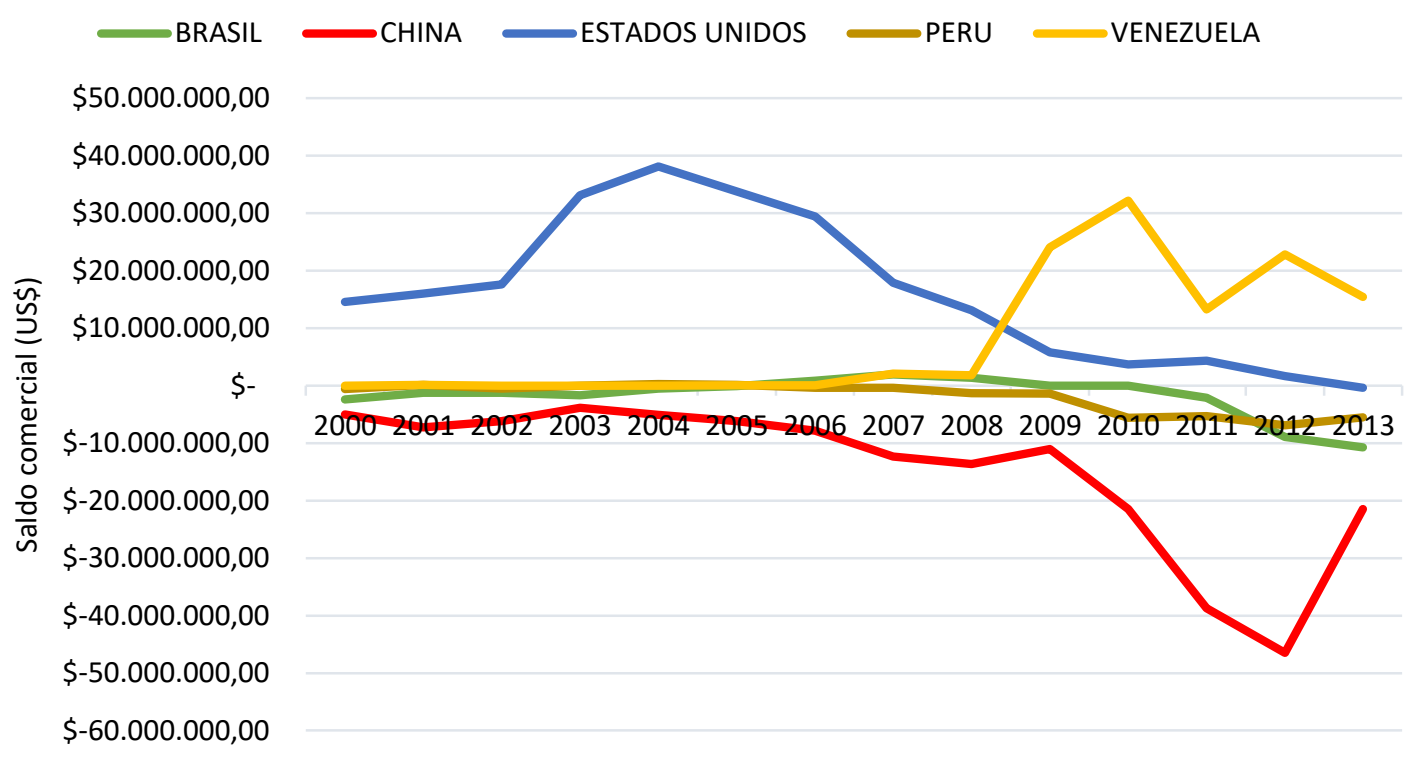

GRÁFICO 9 - Balança Comercial da Bolívia com os principais parceiros comerciais, segundo o setor confecção, referente aos anos de 2000 a 2013, a preços em moeda americana.

Fonte: INE, Bolívia.

Elaboração: Dirce Soken, 2014

Apesar de, no setor têxtil, China e Venezuela serem os principais parceiros comerciais da Bolívia, os saldos comerciais no início dos anos 2000 apresentaram cifras pouco significativas, destaque para o saldo negativo chinês de US\$10.730.803,00 e positivo da Venezuela no valor de US\$ 485.122,00.

Foi a partir do ano 2004 que os produtos têxteis chineses se fizeram mais presentes no saldo comercial boliviano totalizando US\$23.656.270,00, já o mercado venezuelano começou a reagir a partir de 2008 quando atingiu o saldo máximo de US\$73.367.839,00 e se manteve em US\$10.598.070,00 posteriormente.

Entretanto, a expansão do mercado chinês na Bolívia é cada vez maior no ano de 2012. O saldo comercial do país atingiu o valor máximo de US\$ $83.641 .969,00$ e se manteve em US\$ 46.469.465,00 nos períodos seguintes. 


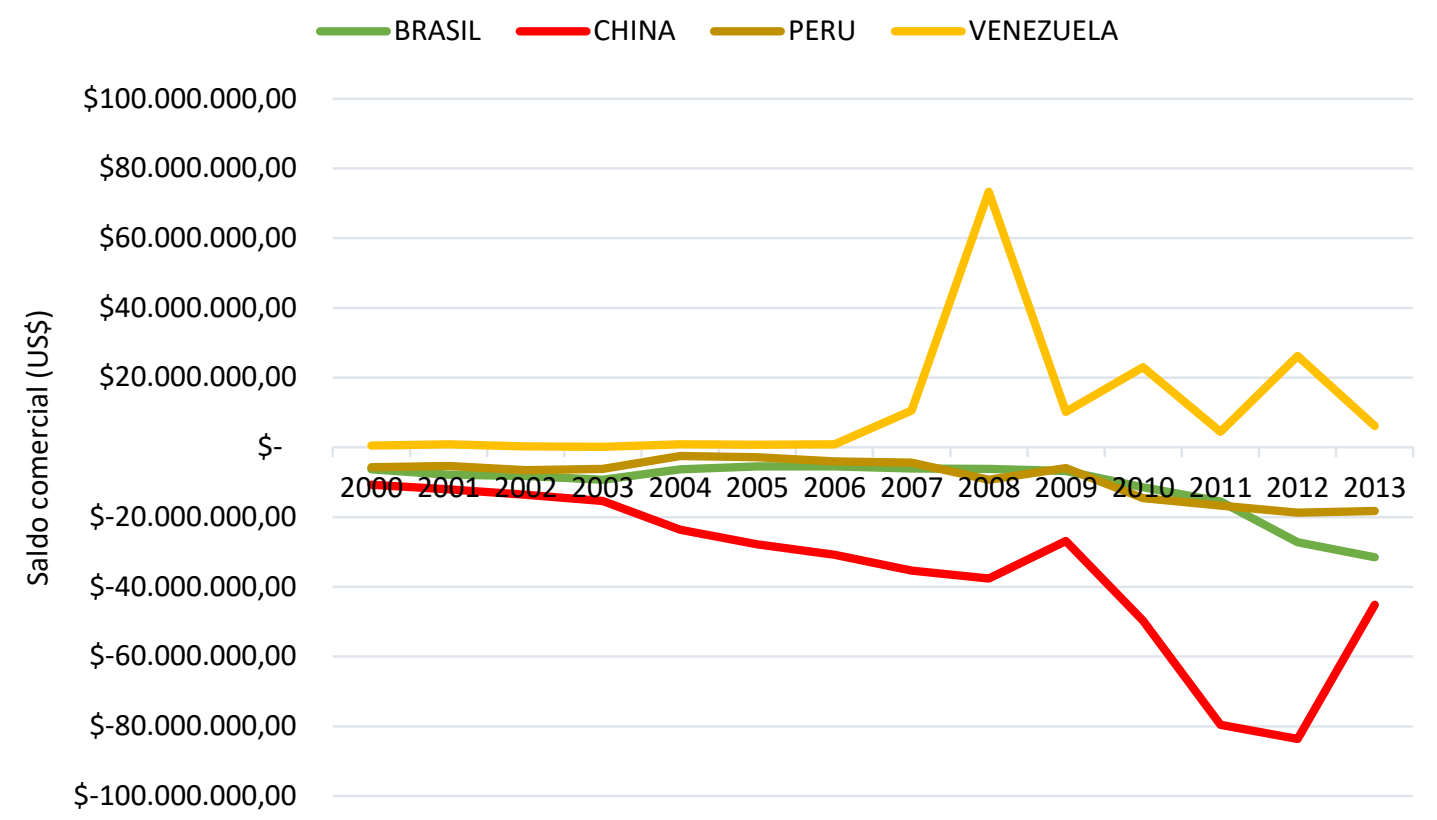

GRÁFICO 10 - Balança Comercial da Bolívia com os principais parceiros comerciais, segundo o setor têxtil, referente aos anos de 2000 a 2013, a preços em moeda americana.

Fonte: INE, Bolívia.

Elaboração: SOKEN, D., 2014

Para uma análise comparativa, utilizou-se do gráfico 11 "Participação do setor têxtil no total de importação de manufaturados da Bolívia, segundo principais países, referente aos anos de 2000 a 2013" e verificou-se que no setor têxtil é grande a participação do mercado chinês nas importações da Bolívia em torno de 50\%. O Brasil e o Peru também têm participações expressivas no mercado boliviano em torno de 18,9\% e $14,6 \%$ respectivamente. 


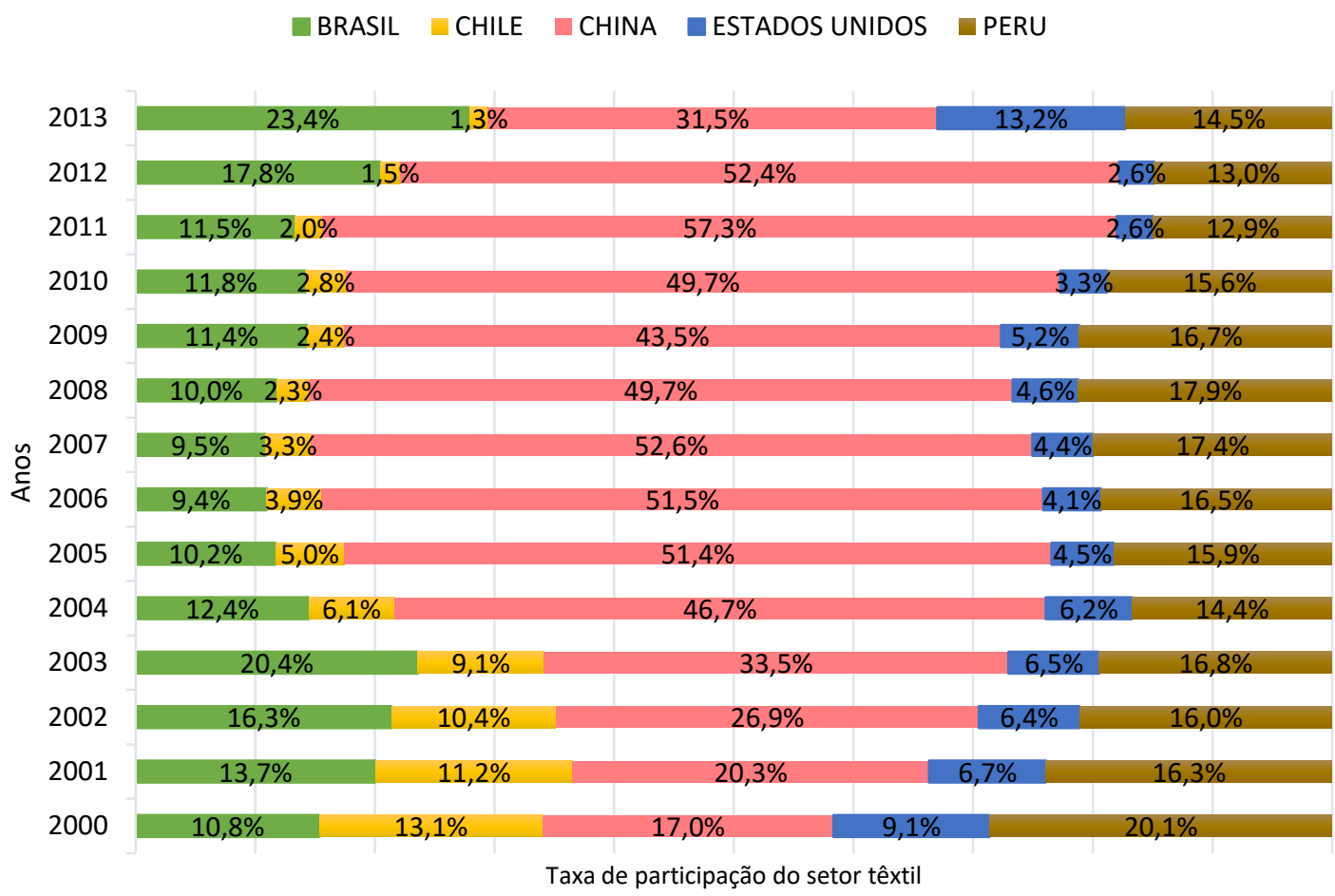

GRÁFICO 11 - Participação do setor textil no total de importação de manufaturados da Bolívia, segundo principais países, referente aos anos de 2000 a 2013

Fonte: INE, Bolívia.

Elaboração: SOKEN, D., 2014

Os produtos chineses ultrapassam 50\% de participação no setor de confecção boliviano. Cabe destaque para os Estados Unidos que teve uma participação significativa entre os anos de 2000 até 2005 , oscilando entre $17,1 \%$ e $12,1 \%$.

O Peru e a Colômbia se mantém com a participação de 7\%. Já o Chile teve participação de $13,9 \%$, no ano de 2000, mas no ano de 2004 caiu para 8,2\% e segue em queda para os demais períodos com tendência a zero. 


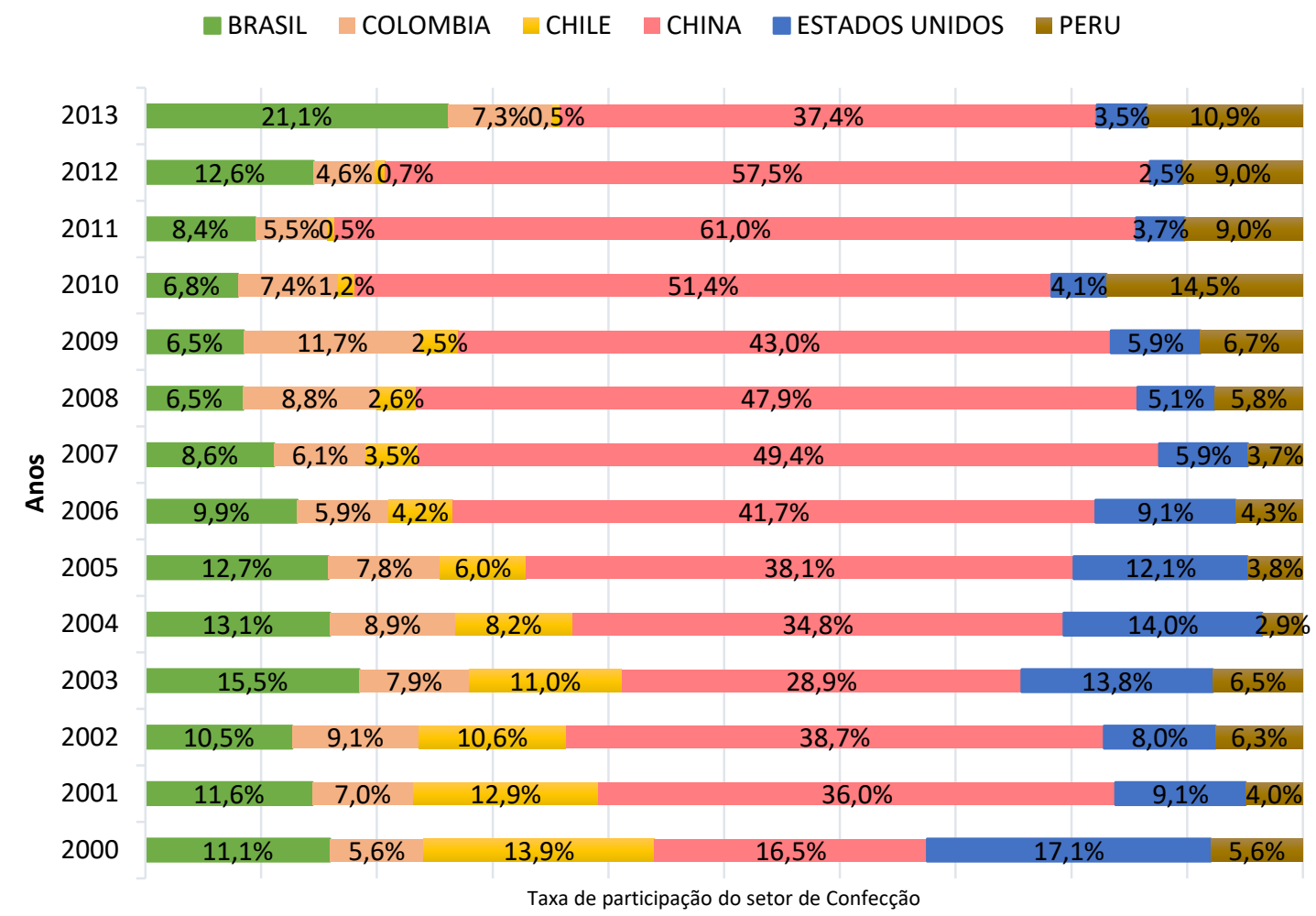

GRÁFICO 12 - Participação do setor de confecção no total de importação de manufaturados da Bolívia, segundo principais países, referente aos anos de 2000 a 2013

Fonte: INE, Bolívia.

Elaboração: SOKEN, D., 2014

Para além dos resultados da balança comercial boliviana, cabe nessa análise a inclusão dos dados da pesquisa do INE/Bolívia "Encuesta de Opinión Empresarial y Expectativas de la Industria Manufacturera”, referente aos anos de 2000 a 2008, os quais revelaram os principais fatores que, segundo a classe empresarial, dificultam a utilização plena da capacidade produtiva da indústria boliviana. No ano de 2008, destacam-se alguns, como: a disponibilidade de matéria-prima que representou 18,33\%; a concorrência pelo contrabando (13,1\%); a demanda reduzida (14,28\%); e o aumento de preços dos insumos $(12,42 \%)$, esses foram os principais fatores apontados pelos empresários bolivianos. 


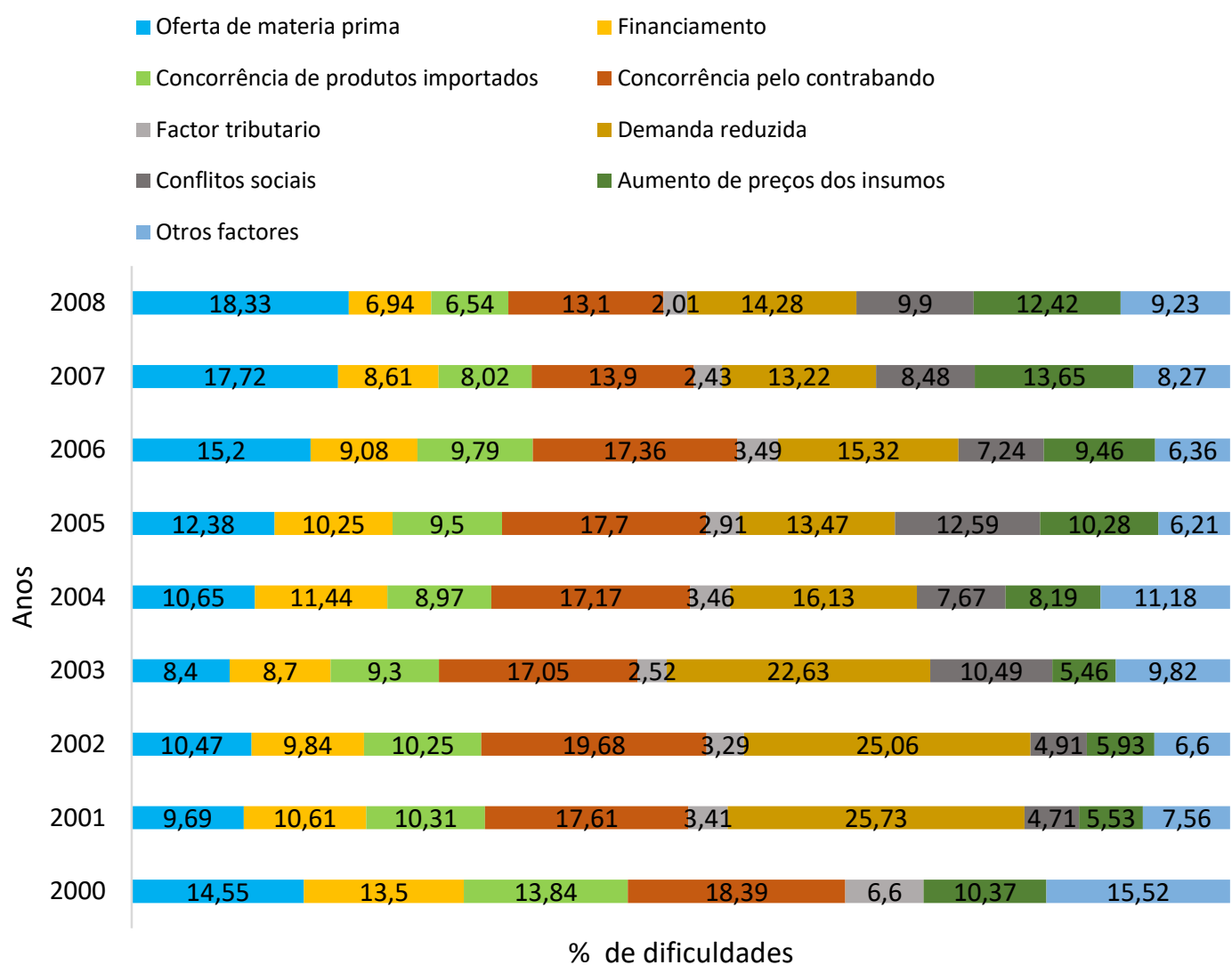

GRÁFICO 13 - Fatores que impedem a utilização plena da capacidade produtiva da indústria boliviana, referente aos anos de 2000 a 2008

Fonte: INE/Bolívia - "Encuesta de Opinión Empresarial y Expectativas de la Industria Manufacturera". Elaboração: SOKEN, D., 2014

A indústria nacional não consegue atender à crescente demanda por bens de consumo das classes populares, segundo Tassi et al (2013, p. 72) isso desencadeou um aumento das importações ilegais de bens de consumo sob coordenação dos comerciantes aymaras que souberam atender as necessidades da demanda desses populares, consequentemente se posicionaram à frente do processo de acumulação mercantil de produtos populares na Bolívia.

É importante mencionar que 59\% dos objetos contrabandeados para a Bolívia têm como entrada o porto do Chile, pela Zona Franca de Iquique (ZOFRI) chegam veículos automotivos, tratores, artigos eletrônicos de imagem e som, seguido por Brasil com 23\% de calçados, caldeiras e equipamentos mecânicos; o Chile com 9\% em máquinas e equipamentos mecânicos; Argentina com 5\% em farinha; Peru com 2\% com combustíveis e minerais e Paraguai com 1\% em tabaco (TASSI et al, 2013, p. 75).

O contrabando de roupas usadas na Bolívia também é procedente de Iquique, depois de devidamente organizado segue para o interior do país. Recentemente, o governo 
boliviano tem restringido a circulação de roupas contrabandeadas o que fez muito importador desistir do comércio ilegal e substituir por roupas novas da China, principal fornecedor para as áreas rurais e fronteiras. Sobretudo, o comércio de roupas de produção boliviana, como camisas, camisetas e calças tem tido maior mercado na fronteira e no norte do país (TASSI et al, 2013, p.110).

Para compreender o recente dinamismo da atividade industrial têxtil e de confecção boliviana é importante observar o crescimento do consumo energético. Ao longo dos anos de 2000 a 2011 a taxa de crescimento do consumo de energia elétrica da indústria boliviana variou entre 1,6\% a 8,2\%, apenas nos anos de 2005/2004 e 2008/2007 sofreu variações próximas de zero. Essa queda teve contribuições do setor de vestuário que puxou para baixo a média de crescimento e atingiu o nível negativo de $21 \%$, seguindo em queda nos anos seguintes chegando a $-22 \%$, referente aos anos de 2005/2006.

Apesar de a indústria no geral apresentar-se em declínio entre os anos de 2007 e 2008 os setores de vestuário e malharia atingiram as taxas positivas de $19,8 \%$ e $23 \%$ respectivamente. E quando o setor industrial retoma a escalada do crescimento no período seguinte, 2009/2008, os setores têxtis e vestuário sofreram quedas bruscas em $-10 \%$ e - $47 \%$ para o mesmo período.

Foi em 2010/2009 que o setor de vestuário obteve a melhor taxa positiva de 32\%, que elevou o nível da indústria para 5,6\%; já os setores de têxteis e malharia se mantiveram com as taxas negativas de $7 \%$. 
Fiação, tecelagem e acabamento de tecidos Fábrica de malharia

Fábrica de vestuário, exceto calçados $\quad$ INDUSTRIA

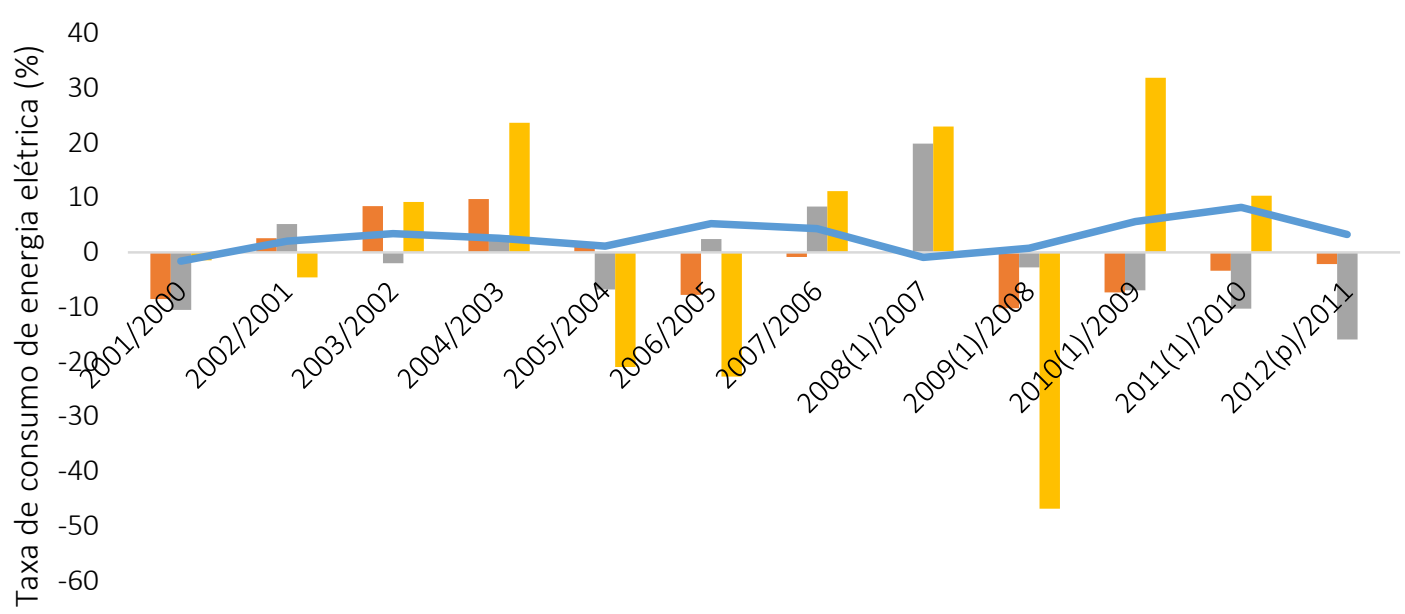

GRÁFICO 14 - Taxa de consumo de energia elétrica do setor têxtil e confecção, segundo Índice da Indústria boliviana $(1990=100)$, referente aos anos de 2000 a 2012

Fonte: INE/Bolívia - "ENCUESTA TRIMESTRAL A LA INDUSTRIA MANUFACTURERA (ETIM)".

(p) Dados preliminares

(1) Dados atualizados desde do ano de 2008

Elaboração: SOKEN, D., 2014

Considerando a onda de otimismo que paira sobre a economia boliviana, percebese que o setor têxtil e confecção retomam o crescimento industrial. A taxa de utilização da capacidade produtiva do setor alcançou no ano de 2004 o nível da indústria nacional e obteve a taxa de 58,61\%, no ano seguinte sofreu uma queda de quatro pontos, no entanto, entre os anos 2006 e 2010 as taxas ficaram acima de 62\%. Essa boa fase do setor têxtil e confecção é resultado do dinamismo da Balança Comercial do país e da reestruturação do mercado de trabalho que intensificou o uso da mão de obra familiar nos processos de produção e comercialização. 


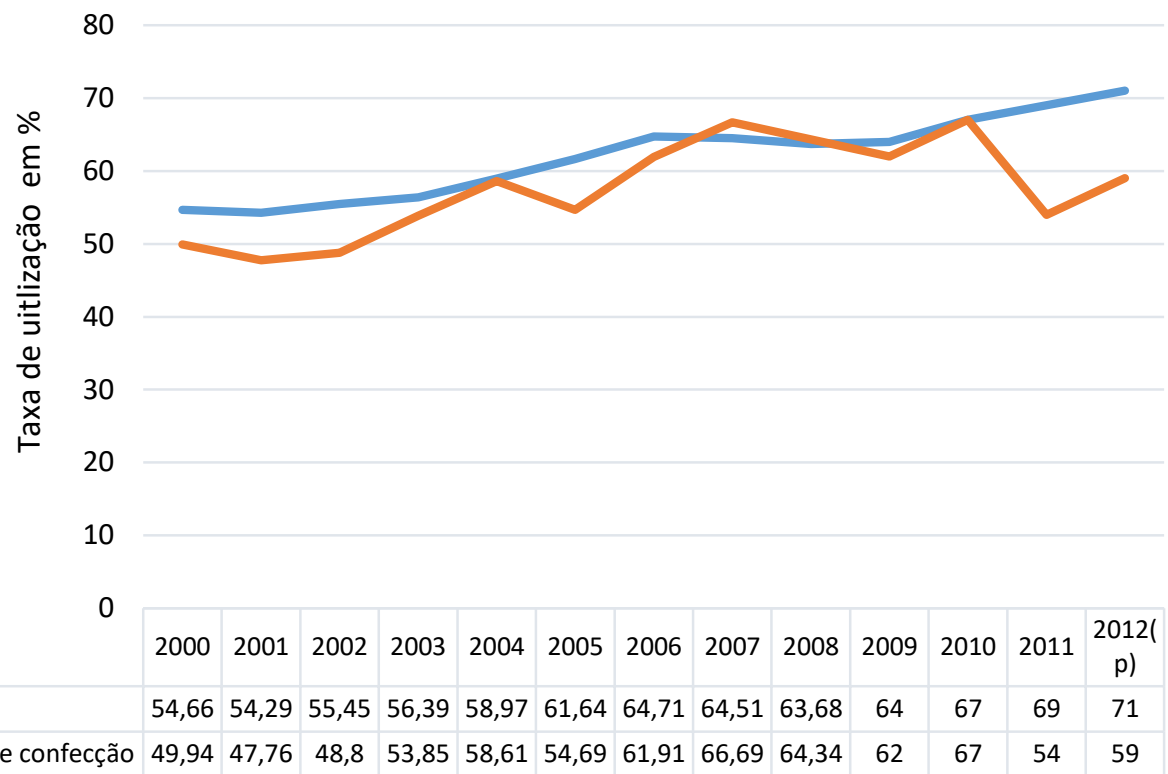

GRÁFICO 15 - Taxa de utilização da capacidade produtiva instalada do setor têxtil e confecção e da indústria boliviana, nos anos de 2000 a 2012.

Fonte: INE/Bolívia - "Encuesta de Opinión Empresarial y Expectativas de la Industria Manufacturera". (p): Dados preliminares.

Nota: A partir do primeiro trimestre do ano de 2011 o questionário foi realizado com base do ano de 2007 Elaboração: SOKEN, D., 2014

Destacam-se algumas observações, os empresários do setor industrial da Bolívia consideram pouco relevante o preço da força de trabalho, mas apontam a baixa oferta de mão de obra qualificada como um dos fatores que impactam na utilização plena da capacidade produtiva. Além disso, cabe lembrar que a flexibilização do mundo do trabalho, discutida por vários autores citados nesse capítulo, tem inserido a mão de obra boliviana no circuito de produção têxtil e confecção mediante o uso de distintas formas de organização social do trabalho, dada pela divisão sexual do trabalho, pelo baixo custo da mão de obra feminina e por subcontratação de mão de obra familiar realizada em domicílio.

\subsubsection{O uso da mão de obra feminina no processo produtivo do setor têxtil e confecção}

Segundo Poveda (2003) o ajuste estrutural por qual passou a Bolívia no início da década de 1980 marcou o momento no qual se observa uma intensificação do uso de formas de contratação de mão de obra não capitalistas, ou seja, incorporação de mão de obra familiar não remunerada (POVEDA, 2003, p. 3). 
Essas formas familiares de produção se mesclam as relações informais de trabalho e criam ambientes favoráveis para as empresas contratantes reduzirem custos por meio de contratos de subcontratação, no caso do setor de tecido e confecção a remuneração do trabalho é paga por peça produzida.

Os dados do INE/Bolívia (2011) revelam que a população feminina ocupada está fragilizada perante o processo de flexibilização do mercado de trabalho, pois cerca de $31 \%$ são trabalhadoras por conta própria e 35\% trabalham com a família sem remuneração ou como aprendizes, seguida por apenas $3 \%$ que são operárias e $24 \%$ na categoria de funcionária, ou seja, somente essas últimas que recebem salários de acordo com a jornada de trabalho determinada por contrato. Em contrapartida, 17\% dos homens são operários e $25,77 \%$ são funcionários. Já aqueles que trabalham por conta própria perfazem $35,88 \%$ e 13,46\% trabalham com a família ou são aprendizes sem remuneração.

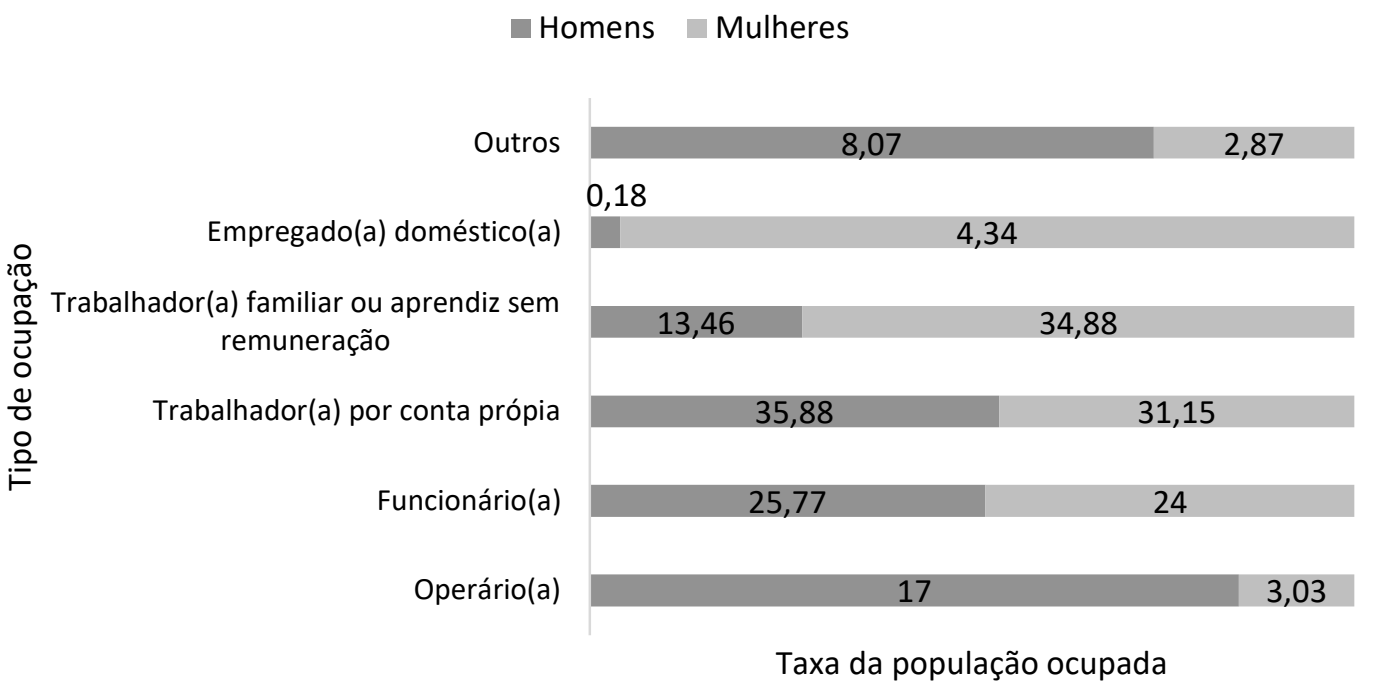

GRÁFICO 16 - Distribuição da população ocupada da Bolívia, segundo a principal ocupação, por sexo, referente ao ano de 2011.

Fonte: INE, Encuesta de Empleo (EE) 2009-2010

Elaboração: SOKEN, D., 2014

Na Bolívia, é cada vez maior o trabalho a domicílio articulado às formas empresariais, semi-empresariais e familiares. A forma familiar corresponde às unidades produtivas donas dos meios de produção, mas que não contratam assalariados porque a mão de obra é familiar. A forma empresarial é aquela por meio da qual a organização do trabalho é por assalariamento e existe divisão entre o proprietário ou gerente e o processo de produção em si. Na forma semiempresarial existe a propriedade privada dos meios de 
produção e assalariamento da mão de obra, no entanto, o proprietário também participa do processo produtivo (POVEDA, 2003, p.9).

Informa Poveda (2003), que o formato semi-empresarial articulado às unidades familiares de trabalho a domicílio são comuns no setor de confecção. No formato familiar a relação é via subcontratação e quando a organização é empresarial a relação é via microcrédito comercial (POVEDA, 2003, p. 19 e 20).

\begin{tabular}{|c|c|c|c|c|c|c|c|c|}
\hline \multirow[t]{2}{*}{ Itens } & \multicolumn{2}{|c|}{ Subcontratado } & \multicolumn{6}{|c|}{ Formas de subcontratação (\%) } \\
\hline & Total unidades familiares & Contratada por empresas (\%) & a & $\mathrm{b}$ & c & $d$ & $\mathrm{e}$ & f \\
\hline Tecido & 24 & 37,5 & 40 & 0 & 20 & 20 & 0 & 0 \\
\hline Confecção & 23 & 17 & 100 & 0 & 0 & 0 & 0 & 0 \\
\hline Calçado & 4 & 0 & 0 & 0 & 0 & 0 & 0 & 0 \\
\hline \multicolumn{9}{|c|}{ a. Recebe matéria-prima do contratista } \\
\hline \multicolumn{9}{|c|}{ b. Recebe pagamento adiantado do contratista } \\
\hline \multicolumn{9}{|c|}{ c. Recebe matéria-prima e pagamento adiantado do contratista } \\
\hline \multicolumn{9}{|c|}{ d. Recebe ajuda em períodos de alta demanda do contratista } \\
\hline e. Recebe m & & ntado e ajuda em pe & manc & & & & & \\
\hline
\end{tabular}

TABELA 6 - Formas de subcontratação de unidades familiares por unidade empresarial dos setores têxtil, vestuário e calçados, cidades de La Paz e El Alto, Bolívia, ano de referência 2002.

Fonte: Encuesta de Trabajo, Finanzas y Pobreza desde la perspectiva de las mujeres, Bolívia, 2002.

Elaboração: POVEDA, 2003, p.20

Adaptação: SOKEN, D., 2014

Poveda (2003, p. 17) descreve o processo de organização e divisão do trabalho na unidade doméstica do setor de confecção:

El trazo de los modelos es realizado por una trabajadora familiar y luego el titular dobla y corta la tela y los forros, ayudado por el outro trabajador familiar. Luego, el titular entrega la tela ya cortada y los demás insumos a las unidades familiares, donde se completan las fases de confección, armado y costura. La prenda ya concluída es entregada al titular, quien realiza el control de calidad final antes de vender la prenda, venta que se realiza a clientes que él tiene, y que comercializan la mercadería en la localidade fronteriza de Quijarro o en una tienda própria que tiene en la ciudad de Oruro, donde contacta intermediários que llevan mercadería (aunque en menores cantidades) a la frontera con Chile (POVEDA, 2003, p. $18) .{ }^{68}$

O autor ressalta que, na baixa temporada da produção do setor de confecção trabalham apenas os trabalhadores familiares não remunerados, somente no período de

\footnotetext{
68 Tradução: O riscado dos moldes é feito por uma trabalhadora familiar e logo o titular dobra e corta o tecido e os forros, recebe ajuda de outro trabalhador familiar. Depois o titular entrega o tecido cortado e os outros insumos para as unidades familiares, onde completam as fases da confecção, montagem e costura. A peça já concluída é entregue ao titular, quem realiza o controle de qualidade final antes de vender a peça, venda que se realiza aos clientes dele, e que comercializam a mercadoria em localidade fronteiriça de Quijarro ou em loja própria na cidade de Oruro, onde contacta intermediários que levam a mercadoria (ainda que em menor quantidade) a fronteira com Chile.
} 
alta demanda articulam-se outras unidades familiares para dar conta da produção (POVEDA, 2003, p.18).

Conforme dados do INE/Encuesta de Empleo (2009-2010), verifica-se que o rendimento das mulheres operárias, trabalhadoras autônomas e empregadas domésticas atinge quase o dobro do salário mínimo somente a partir do ano de 2009, tal situação é superada por aquelas que são funcionárias e recebem mais que o dobro do salário mínimo desde do ano de 2001.

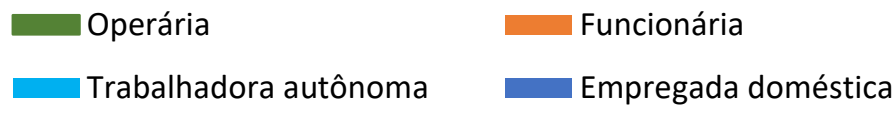

—SALARIO MÍNIMO NACIONAL

2000

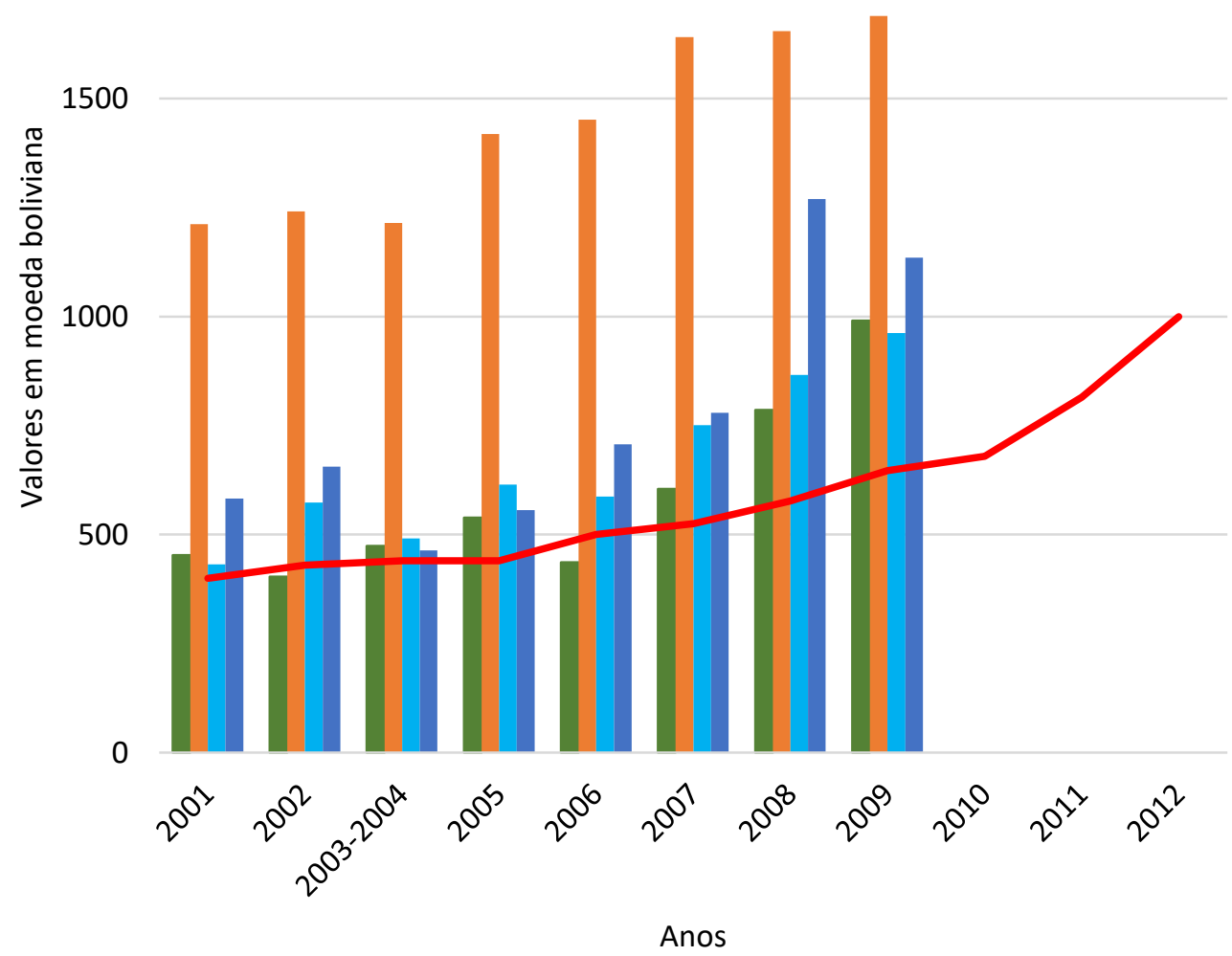

GRÁFICO 17 - Remuneração da população feminina ocupada nas principais atividades, segundo o tipo de emprego na Bolívia, referente aos anos de 2001 a 2009.

Fonte: INE, Encuesta de Empleo (EE) 2009-2010

Elaboração: SOKEN, D.S., 2014

No que tange ao rendimento masculino, a situação é bem superior ao feminino. Entre os anos de 2005 e 2006, os operários, trabalhadores autônomos e empregados 
domésticos já ganhavam o dobro do salário mínimo. Além disso, os funcionários recebiam níveis de salário bem acima do que recebiam as funcionárias. Em 2009 o limite salarial de uma funcionária era de mil e setecentos bolivianos, enquanto que do masculino chegava a dois mil e duzentos bolivianos, significando um salário mínimo a mais para os homens.

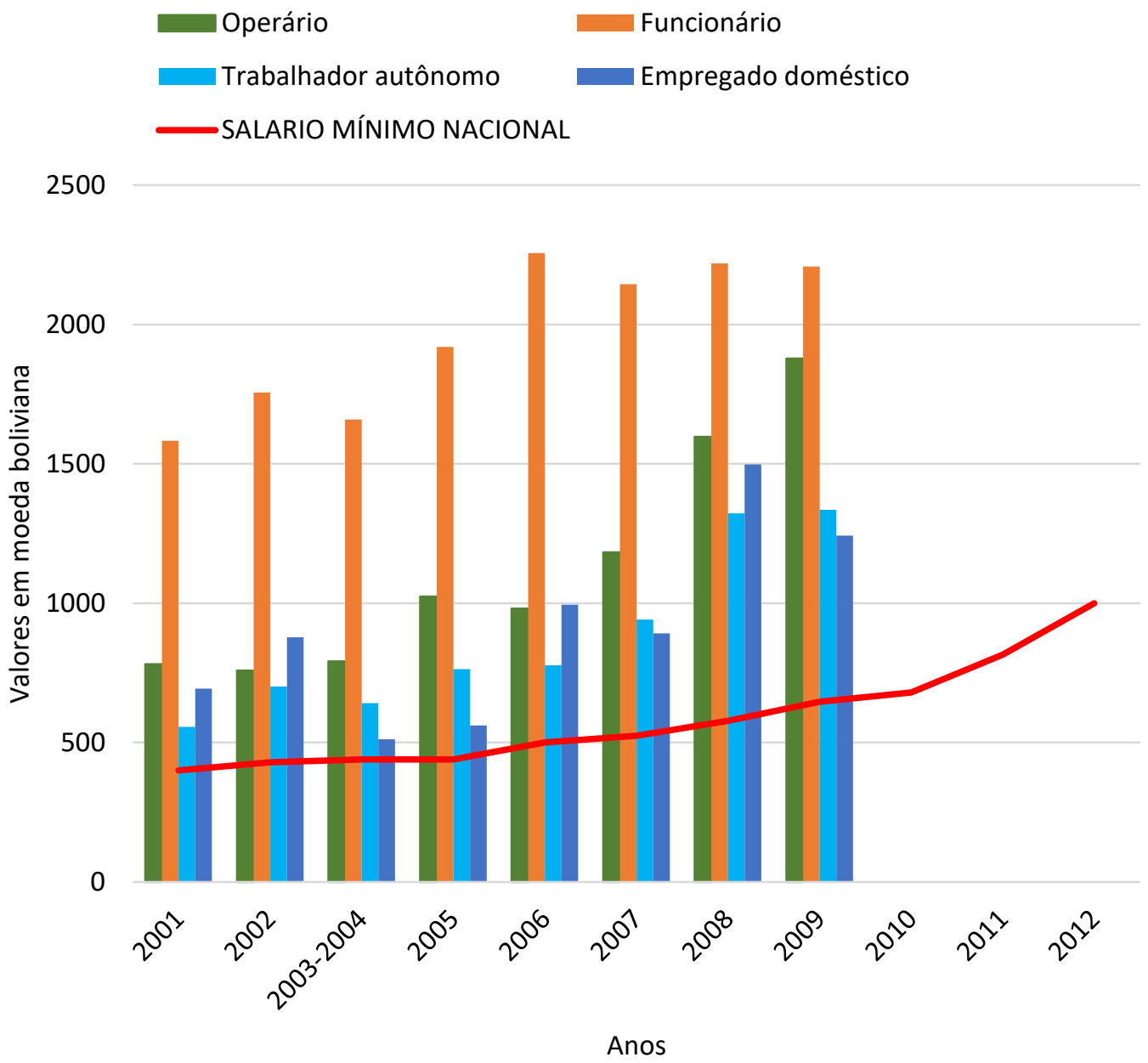

GRÁFICO 18 - Remuneração da população masculina ocupada nas principais atividades, segundo o tipo de emprego na Bolívia, referente aos anos de 2001 a 2009.

Fonte: INE, Encuesta de Empleo (EE) 2009-2010

Elaboração: SOKEN, D.S., 2014

Nota-se que o crescimento por trabalho autônomo entre as mulheres tem como reflexo o aumento dos casos de subcontratação de trabalho familiar por formas empresariais, semi-empresariais e entre familiares, tal organização precária do trabalho está vinculada ao processo de trabalho industrial capitalista fruto da descentralização das funções das grandes empresas, que transforma as unidades familiares em novos operários (POVEDA, 2003, p.7 e 29). 


\subsection{Aspectos do mercado de trabalho feminino brasileiro e boliviano}

Os dados estatísticos do Instituto Brasileiro de Geografia e Estatística (IBGE) e do Instituto Nacional de Estadística da Bolívia (INE) foram organizados de modo que fosse possível observar as características da inserção da mulher no mercado de trabalho nesses dois países. Os dados tabulados compreendem períodos diversos. Cabe mencionar a limitação da base de dados, considerando que as pesquisas estatísticas podem revelar parcialmente a participação da mulher no mercado de trabalho.

\subsubsection{Faixa etária e taxa da população ocupada}

Um dos fatores determinantes para a inserção e permanência das mulheres no mercado de trabalho se refere idade. No Brasil, o mercado de trabalho feminino tem mantido um perfil adulto, mulheres com idade entre 25 e 49 anos têm permanecido no mercado de trabalho por mais tempo, em 1970 eram aproximadamente 20\%, em 1990 estavam ativas cerca de 50\% das mulheres da PEA, em 2002 esse índice subiu para próximo de $70 \%$. Está também em crescimento a permanência de mulheres com a idade de 50 e 59 anos, que há 32 anos era de $15 \%$ das mulheres no mercado de trabalho nacional, atualmente são $50 \%$ e aquelas com 60 anos e mais de atividade que representavam $8 \%$, agora são $20 \%$ das mulheres empregadas no país (IBGE).

\begin{tabular}{|c|c|c|c|c|}
\hline \multirow{2}{*}{ Faixa etária } & \multicolumn{4}{|c|}{ Taxa de atividade feminina } \\
\hline & 1970 & 1990 & 2000 & 2010 \\
\hline 10 a 14 & $6,50 \%$ & $10,60 \%$ & - & - \\
\hline 15 a 19 & $23,60 \%$ & $41,40 \%$ & \multirow{3}{*}{$56,3 \%$} & \multirow{3}{*}{$58,8 \%$} \\
\hline 20 a 24 & $27,70 \%$ & $52,90 \%$ & & \\
\hline 25 a 29 & $23,10 \%$ & $52,70 \%$ & & \\
\hline 30 a 39 & $20,10 \%$ & $54,70 \%$ & \multirow{2}{*}{$61,1 \%$} & \multirow{2}{*}{68,1} \\
\hline 40 a 49 & $19,50 \%$ & $49,50 \%$ & & \\
\hline 50 a 59 & $15,40 \%$ & $34,50 \%$ & $39 \%$ & $50,2 \%$ \\
\hline 60 anos e mais & $7,90 \%$ & $11,50 \%$ & $10,6 \%$ & $16,5 \%$ \\
\hline
\end{tabular}

TABELA 7 - Taxa de atividade feminina por faixa etária, nos anos de 1970, 1990, 2002 e 2010 - Brasil Fonte: PNAD/Censo/IBGE

Elaboração: SOKEN, D.S. 
Com base nos Censos demográficos brasileiros dos anos de 2000 e 2010, constatou-se que a taxa de atividade da população feminina se elevou para todas as faixas etárias, com destaque aquelas com idade entre 50 a 59 anos que saltou de $39 \%$ no ano de 2000 para 50,2\% em 2010, juntamente as mulheres com idade acima dos 60 anos que passou de $10,6 \%$ para $16,5 \%$ no mesmo período.

Em relação a taxa de atividade masculina, verificou queda nas faixas etárias de jovens de 16 a 29 anos e de 30 a 49 anos, a primeira faixa passou de $81 \%$ para $74,6 \%$ entre os anos de 2000 a 2010; a segunda que era de $91,9 \%$ caiu para $88,8 \%$ para o mesmo período. Já a faixa etária a partir de 50 anos sofreu acréscimos de pelos menos 2 pontos percentuais.

-16 a $29 \square 30$ a $49 \square 50$ a $59 \square 60$ anos ou mais

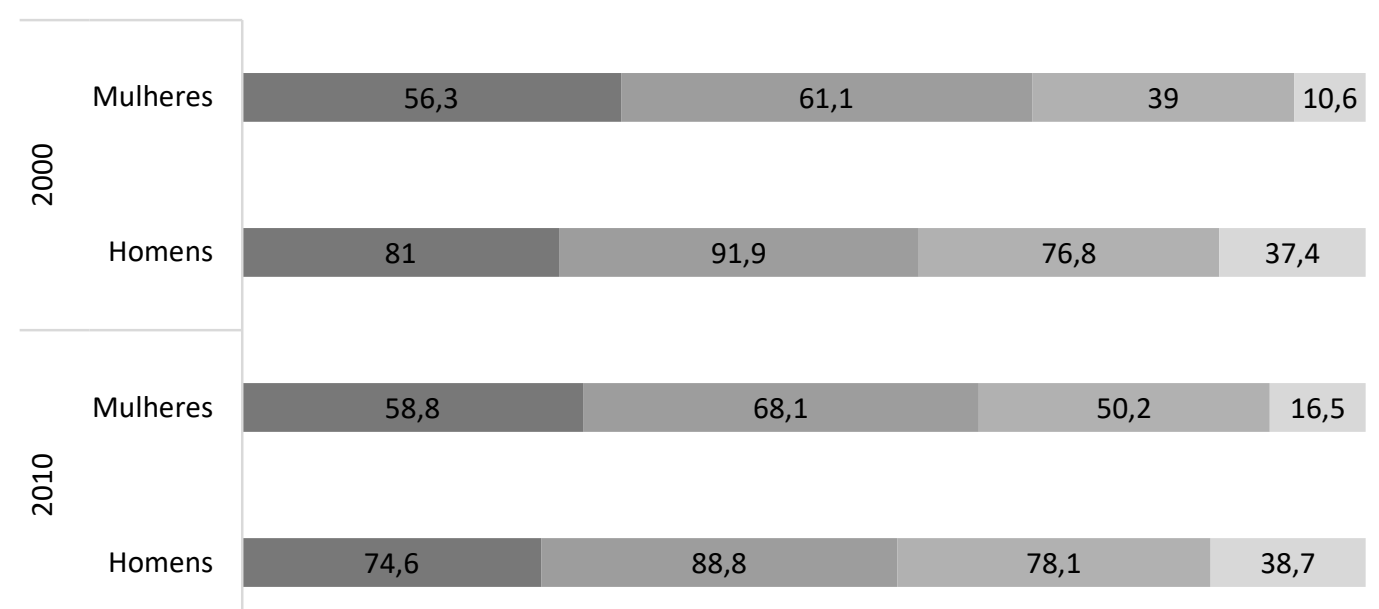

GRÁFICO 19 - Taxa de atividade segundo sexo e por faixa etária, conforme Censos de 2000 e 2010 Brasil

Fonte: Brasil/IBGE/Censos demográficos

Elaboração: SOKEN, D.S.

Se considerar o perfil da população brasileira e boliviana, percebe-se que a população jovem com idade entre 0 a 14 anos é representativa com $24,1 \%$ da população brasileira e $31,4 \%$ da população boliviana. Em contrapartida a população idosa conta com $9,4 \%$ da população brasileira e $8,7 \%$ da população boliviana. 


\begin{tabular}{|c|c|c|c|}
\hline \multirow{2}{*}{$\begin{array}{c}\text { Brasil } \\
\text { Faixa etária }\end{array}$} & \multicolumn{3}{|c|}{ Censo 2010} \\
\hline & Mulheres & Homens & Total \\
\hline Total & 97.348 .809 & 93.406 .990 & 190.755 .799 \\
\hline 0 a 14 anos & $23,2 \%$ & $25,0 \%$ & $24,1 \%$ \\
\hline Acima de 60 anos & $11,8 \%$ & $7,0 \%$ & $9,4 \%$ \\
\hline Bolívia & \multicolumn{3}{|c|}{ Censo 2012} \\
\hline Faixa etária & Mulheres & Homens & Total \\
\hline Total & 5.040 .409 & 5.019 .447 & 10.059 .856 \\
\hline 0 a 14 anos & $30,8 \%$ & $32,1 \%$ & $31,4 \%$ \\
\hline Acima de 60 anos & $9,3 \%$ & $8,1 \%$ & $8,7 \%$ \\
\hline
\end{tabular}

TABELA 8 - Faixa etária de 0 a 14 anos e acima de 60 anos, segundo Censo de 2010 (Brasil) e Censo 2012 (Bolívia), por sexo, em porcentagem da população total.

Fonte: INE/Bolívia/Censo de 2012; IBGE/Brasil/Censo de 2010

Elaboração: SOKEN, D.

A partir da década de $1980^{69}$ com a migração recente da população rural para as cidades, houve uma queda significativa das ocupações femininas no Brasil nas atividades do campo. Entre os anos de 1976 e 1980 a taxa de ocupação caiu de $27 \%$ para $13 \%$ e se manteve até os anos de 1990. Com a expansão do setor do agronegócio no país, percebese que a taxa de atividade feminina no campo volta a aumentar para 24\% no ano de 1993 e mantendo as taxas de $22 \%$ e $19 \%$ nos anos de 1995 e 1998.

A urbanização brasileira implicou em aumento das taxas de ocupação feminina no comércio, em 1970 era de 4\%, alcançou 6\% e 8\% nos anos de 1976 e 1980 e ao longo da década de 1990 atinge taxa significativa de até $13 \%$.

${ }^{69}$ SANTOS, M. A urbanização brasileira. $2^{a}$ edição. São Paulo: Editora Hucitec, 1994. Segundo Santos (1994, p.29) a taxa de urbanização brasileira na década de 1940 era de 26,35\% e em 1980 atinge 68,86\%, entre esse período a população brasileira triplica e a população urbana aumenta em sete vezes e meia. 


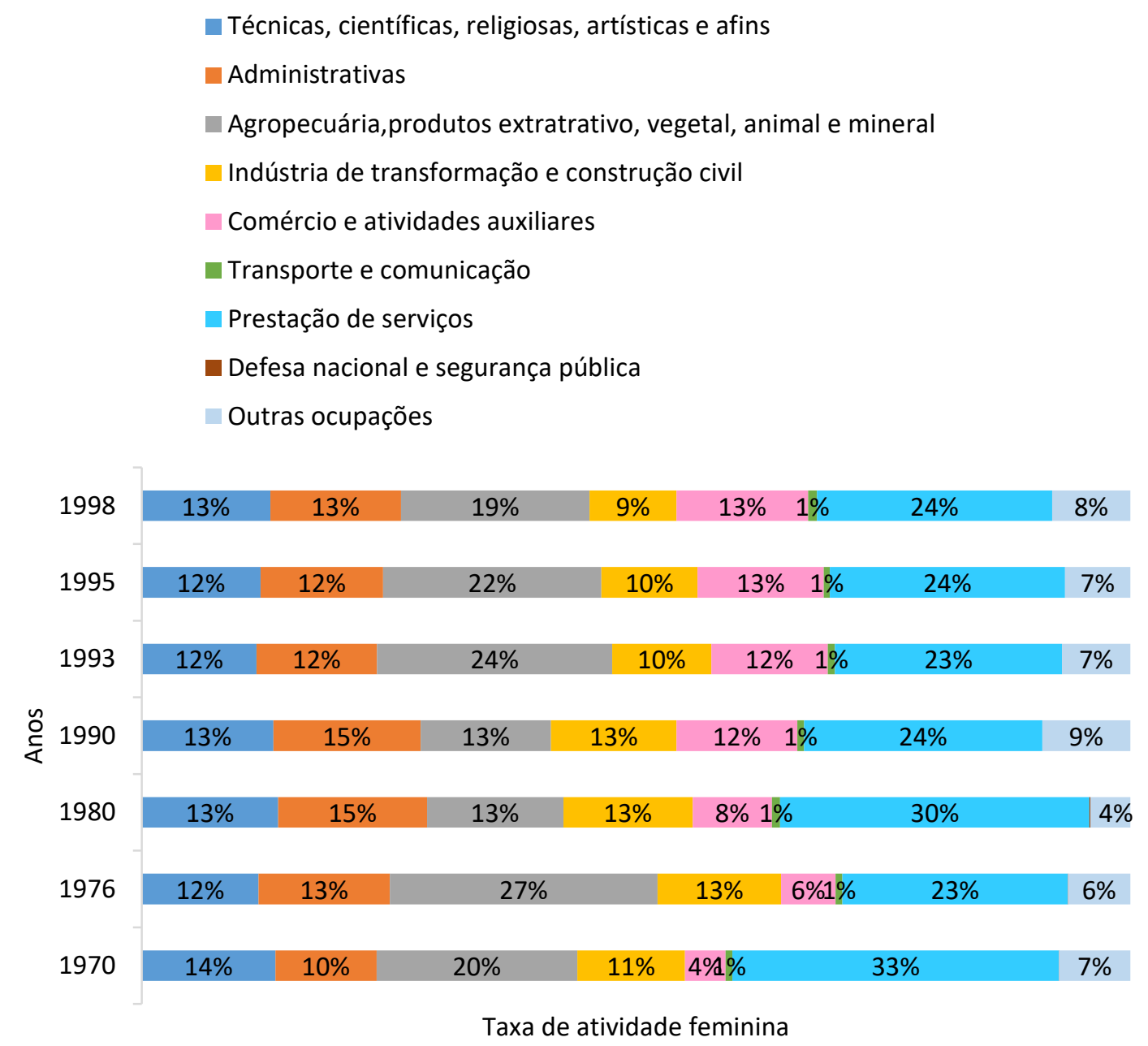

GRÁFICO 20 -Taxa de atividade feminina por categoria ocupacional nos anos de 1970, 1976, 1980, 1990, 1993, 1998 - Brasil

Fonte: Brasil/IBGE/Censos demográficos

Elaboração: SOKEN, D.

Conforme Censos demográficos de 2000 e 2010, percebe-se que a população feminina do Brasil se concentra na atividade de serviços cerca de $79 \%$, enquanto que a população masculina se distribui de modo uniforme nas atividades de agricultura em torno de $20 \%$ e de indústria com $30 \%$, tendo uma representação maior na atividade de serviço com $50 \%$.

\begin{tabular}{l|c|r|r|r|r|r|r|r}
\hline \multirow{2}{*}{$\begin{array}{c}\text { Setores de } \\
\text { atividade }\end{array}$} & \multicolumn{4}{|c|}{ Mulheres } & \multicolumn{4}{c}{ Homens } \\
\cline { 2 - 9 } & 2000 & $\%$ & 2010 & $\%$ & 2000 & $\%$ & 2010 & $\%$ \\
\hline Agricultura & 2.434 .528 & $10,2 \%$ & 3.340 .465 & $9,9 \%$ & 8.853 .695 & $22,6 \%$ & 8.325 .603 & $18,2 \%$ \\
\hline Indústria & 2.941 .779 & $12,3 \%$ & 3.995 .171 & $11,8 \%$ & 10.729 .298 & $27,4 \%$ & 13.503 .614 & $29,5 \%$ \\
\hline Serviços & 18.503 .894 & $77,5 \%$ & 26.449 .462 & $78,3 \%$ & 19.557 .066 & $50,0 \%$ & 23.958 .355 & $52,3 \%$ \\
\hline
\end{tabular}

TABELA 9 - População ocupada por setores de atividade (número de pessoas e porcentagem) distribuída por sexo, conforme Censos demográfico dos anos de 2000 e 2010, Brasil.

Fonte: IBGE/Censos demográficos

Elaboração: SOKEN, D. 
No que diz respeito a posição ocupada da população feminina, constatou-se que no Brasil houve uma relativa melhora dos empregos com carteira assinada de $38,2 \%$ no ano de 2000 aumentou para 44,9\% no ano de 2010. Em contrapartida houve queda dos empregos sem carteira assinada de $27,1 \%$ para $23 \%$ no mesmo período. Sobretudo, o trabalho por conta própria teve leve aumento de $16,7 \%$ para $17,3 \%$, já o trabalho de empregada doméstica sofreu queda significativa de 18,5\% para $15,1 \%$ considerando os anos de 2000 e 2010.

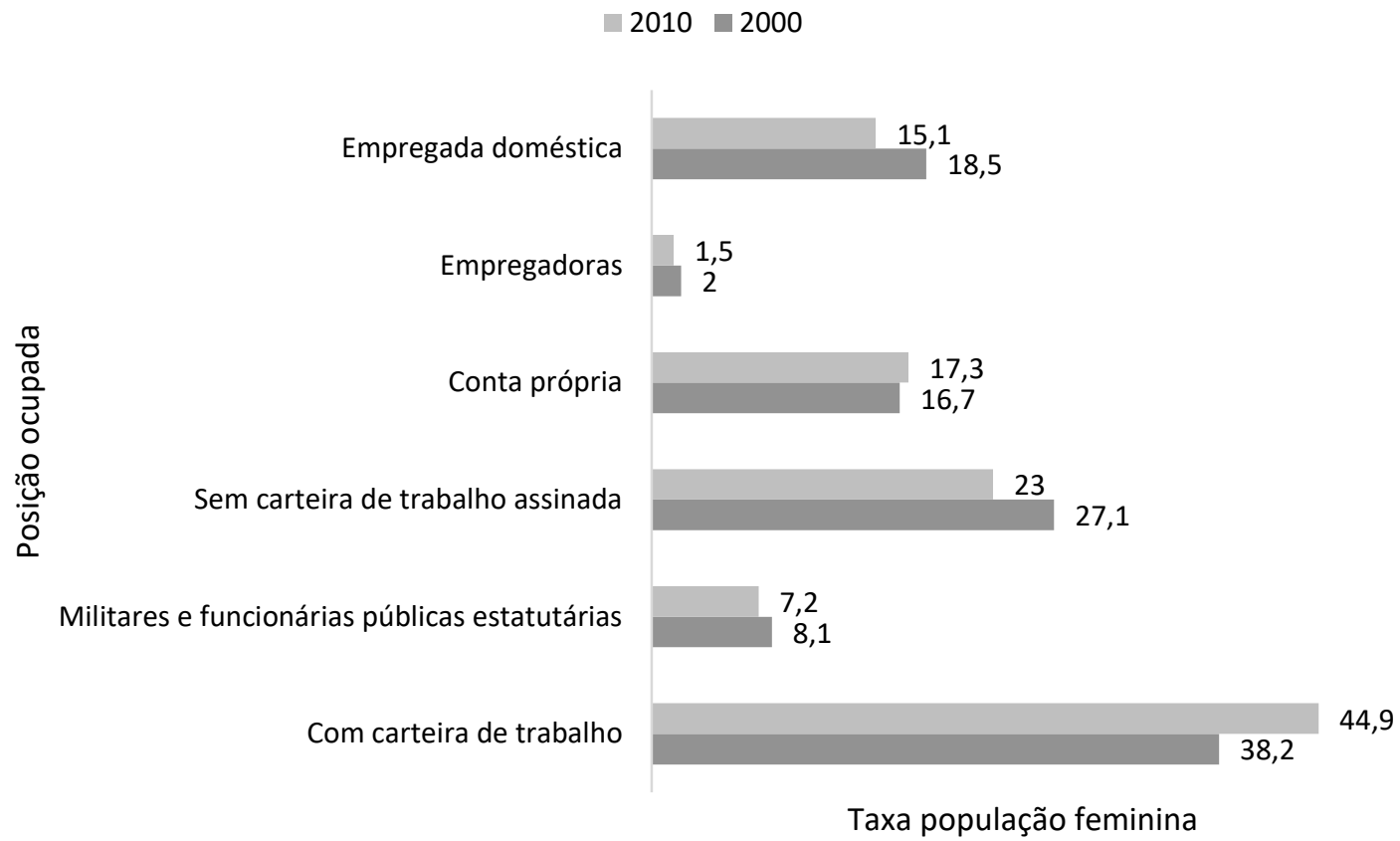

GRÁFICO 21- Distribuição da população ocupada feminina do Brasil, por posição na ocupação (\%), segundo os Censos de 2000 e 2010.

Fonte: IBGE/Censos demográfico

Elaboração: SOKEN, D.

Dentre o período de 2000 a 2011, verificou-se que a população feminina da Bolívia teve significativa alteração com aumento das ocupações de operária de 2,2\% para $3 \%$ e funcionária que era de $18 \%$ agora está em $24 \%$. As reduções aconteceram com as ocupações de trabalho familiar ou aprendiz sem remuneração que era de 36,7\% passou para $34,88 \%$, já o trabalho por conta própria que perfazia $36,5 \%$ no momento se encontra em $31,15 \%$, além do trabalho de empregada doméstica que era de 5,7\% agora representa $4,34 \%$. 


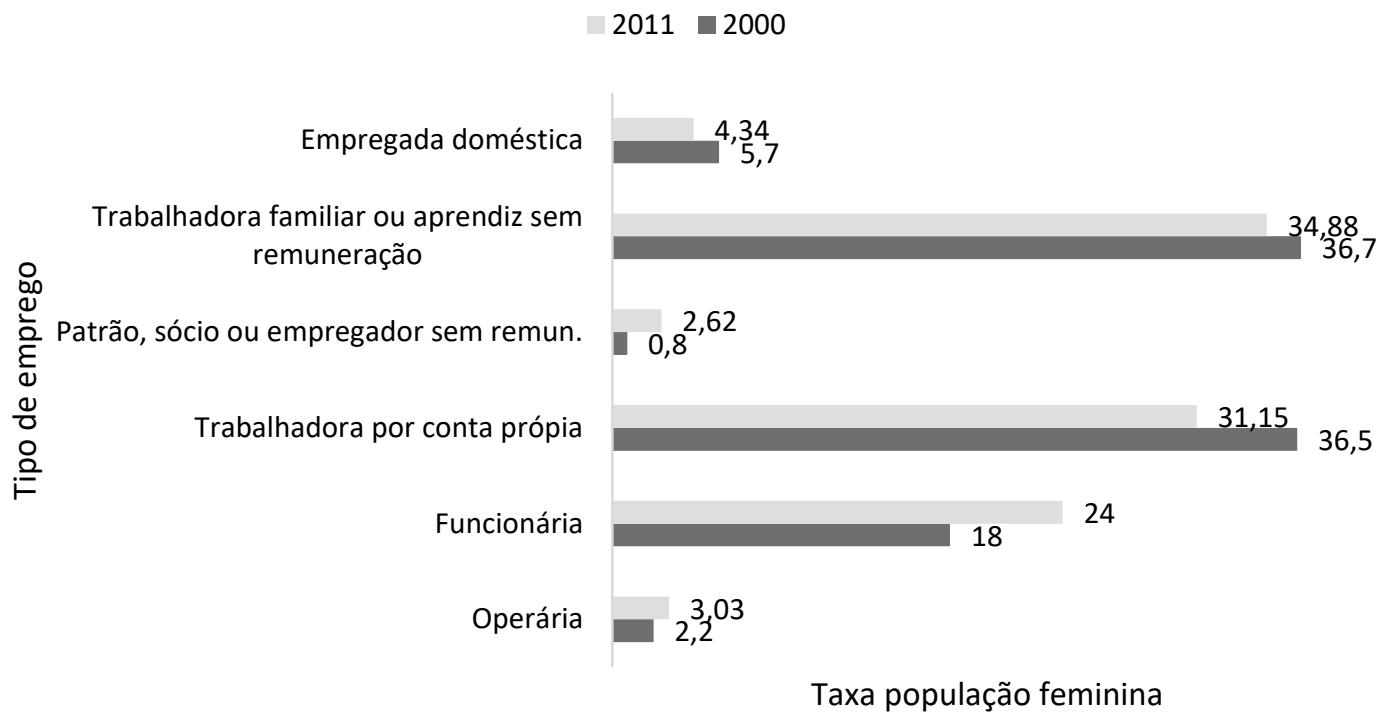

GRÁFICO 22 - Distribuição da população ocupada feminina da Bolívia, segundo tipo de emprego (\%), referente aos anos de 2000 e 2011.

Fonte: INE/ Encuestas de mejoramiento de condiciones de vida (MECOVI 1999 - 2002), Encuesta continua de hogares 2003 - 2004, Encuesta de hogares 2005 - 2013.

Elaboração: SOKEN, D., 2014

Com base nos dados de 2013, constatou-se que existe significativa parcela da força de trabalho boliviana que atua em atividades relacionadas à área rural, como a agricultura, pecuária e pesca $(28 \%)$ e as demais se distribuem nas cidades realizando serviços e vendas no comércio (29,5\%). E no setor industrial, as mulheres aparecem com $8,7 \%$ com atuação na indústria manufatureira. 


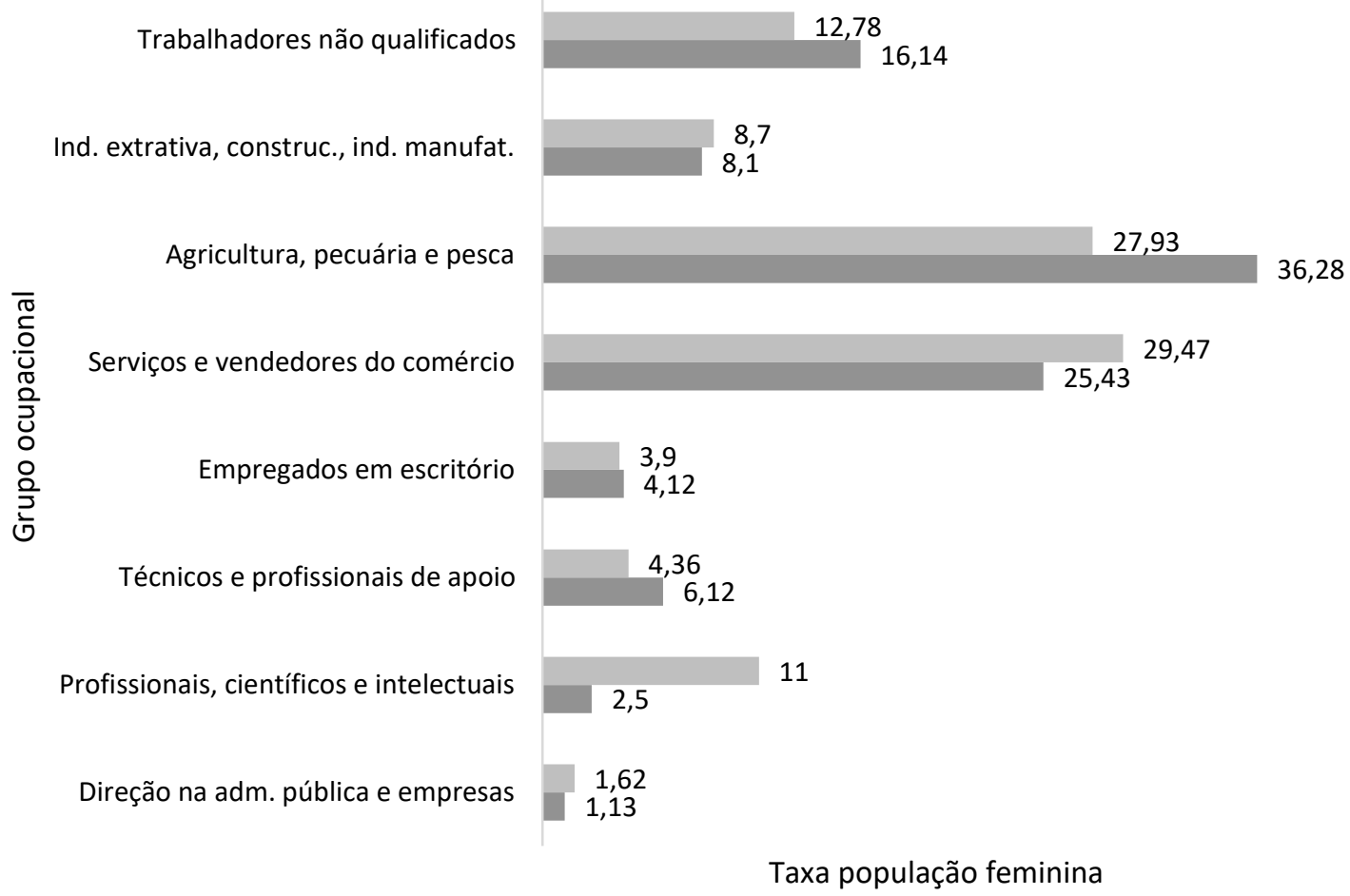

GRÁFICO 23 - Taxa de atividade feminina segundo categoria ocupacional da Bolívia, referente aos anos de 2000 e 2013 .

Fonte: INE/ Encuestas de mejoramiento de condiciones de vida (MECOVI 1999 - 2002), Encuesta continua de hogares 2003 - 2004, Encuesta de hogares 2005 - 2013.

Elaboração: SOKEN, D.

Sendo assim, a partir do momento que a mulher participa da complementação da renda familiar a atividade que se destaca tanto entre as brasileiras como entre as bolivianas está no ramo do comércio e da prestação de serviços. Outras atividades ainda continuam sob a atuação masculina.

\subsubsection{Jornada de trabalho e rendimento médio da população ocupada}

Verifica-se que o rendimento médio se diferencia em relação ao sexo e a posição que cada um ocupa no mercado de trabalho, com base no Censo de 2010 as mulheres brasileiras que ocupavam as carreiras de empregadoras recebiam os melhores rendimentos, o equivalente a 07 salários mínimos, seguida pelas funcionárias públicas e militares que recebiam a média de 04 salários mínimos. No geral, se considerar os Censos de 2000 e 2010 percebe-se que os rendimentos médios da carreira militar e funcionários 
públicos obtiveram em termos nominais a variação positiva de $39,6 \%$ para as mulheres e $43,6 \%$ para os homens.

\begin{tabular}{|c|c|c|c|c|c|c|}
\hline \multirow{2}{*}{ Posição na ocupação } & \multicolumn{3}{|c|}{ Mulheres } & \multicolumn{3}{|c|}{ Homens } \\
\hline & 2000 & 2010 & $\begin{array}{c}\text { Taxa } \\
\text { variação }\end{array}$ & 2000 & 2010 & $\begin{array}{c}\text { Taxa } \\
\text { variação }\end{array}$ \\
\hline Com carteira de trabalho & $\mathrm{R} \$ 1.081,23$ & $\mathrm{R} \$ 1.076,85$ & $-0,4 \%$ & $\mathrm{R} \$ 1.348,19$ & $\mathrm{R} \$ 1.383,19$ & $2,6 \%$ \\
\hline $\begin{array}{l}\text { Militares e funcionárias } \\
\text { públicas estatutárias }\end{array}$ & $\mathrm{R} \$ \mathbf{1 . 4 4 5 , 4 6}$ & $\mathrm{R} \$ \quad 2.017,53$ & $39,6 \%$ & $\mathrm{R} \$ \quad 2.019,01$ & $\mathrm{R} \$ \quad 2.900,10$ & $43,6 \%$ \\
\hline $\begin{array}{l}\text { Sem carteira de trabalho } \\
\text { assinada }\end{array}$ & $\mathrm{R} \$ \mathbf{6 1 9 , 0 9}$ & 557,35 & $-10,0 \%$ & 689,95 & 777,34 & $12,7 \%$ \\
\hline Conta própria & $\mathrm{R} \$ \quad 998,05$ & $\mathrm{R} \$ 1.103,29$ & $10,5 \%$ & $\mathrm{R} \$ \mathbf{1 . 3 4 0 , 0 8}$ & $\mathrm{R} \$ 1.447,55$ & $8,0 \%$ \\
\hline Empregadoras & $\mathrm{R} \$ \mathbf{4 . 6 3 0 , 1 8}$ & $\mathrm{R} \$ 3.794,60$ & $-18,0 \%$ & $\mathrm{R} \$ \quad 6.664,47$ & $\mathrm{R} \$ 5.579,58$ & $-16,3 \%$ \\
\hline SALÁRIO MÍNIMO & 151,00 & 510,00 & $237,7 \%$ & 151,00 & 510,00 & $237,7 \%$ \\
\hline
\end{tabular}

TABELA 10 - Rendimento médio no trabalho principal da população ocupada de 16 anos ou mais de idade por posição na ocupação (em moeda $\mathrm{R} \$$ ), por sexo, para os anos de 2000 e 2010, Brasil.

Fonte: IBGE/Censo demográfico

Elaboração: SOKEN, D.

Apesar dos dados referentes aos rendimentos médios evidenciarem a hierarquia entre os sexos, sendo que os ganhos dos homens estão sempre acima da média das mulheres, ainda assim percebemos ocupações que recebem rendimentos menos desiguais, tais como aqueles que trabalham por conta própria a média de salários mínimos é de 2,2 para as mulheres e 2,8 para os homens; as mulheres com carteira assinada recebem 2,1 salários mínimos e os homens 2,7; já as mulheres que trabalham sem carteira assinada recebem 1,1 salários mínimos e os homens recebem um pouco mais com o valor equivalente a 1,5 salários mínimos. 


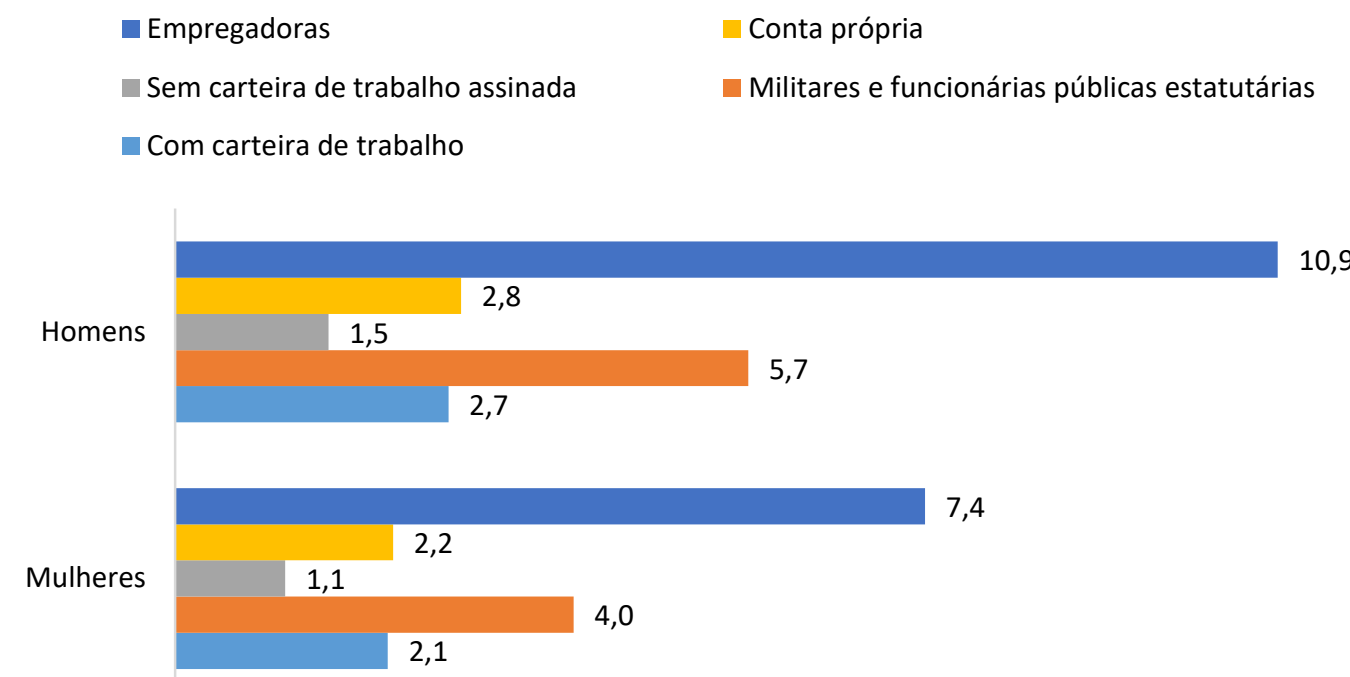

Quantidade de salário mínimo (ano 2010)

GRÁFICO 24 - Rendimento médio no trabalho principal da população ocupada de 16 anos ou mais de idade, por posição na ocupação (em Salário Mínimo), por sexo, para o ano de 2010, Brasil. Fonte: IBGE/Censo demográfico Elaboração: SOKEN, D.

O rendimento das mulheres bolivianas também está abaixo da média masculina, no entanto, com base nos dados de 2001 e 2013, constata-se variações positivas acima de 200\% com destaque a ocupação de patroa, sócia ou empregadora sem remuneração que obteve a variação de $292 \%$; também obteve variação significativa de $267 \%$ a ocupação de trabalhadora por conta própria, bem como a de operária encontramos a porcentagem de $234 \%$.

Observa-se que em ocupação onde predomina a mão de obra feminina que é a empregada doméstica a remuneração masculina é melhor, no ano de 2013 verificou que enquanto uma trabalhadora doméstica recebe o valor nominal de Bs\$1.490,00 (mil e quatrocentos e noventa bolivianos), o trabalhador doméstico recebia o valor de Bs\$ 2.017,00 (dois mil e dezessete bolivianos), que representou ganho de cerca de $40 \%$ do salário mínimo em relação ao rendimento feminino. 


\begin{tabular}{|c|c|c|c|c|c|c|}
\hline \multirow[b]{2}{*}{ Tipo de emprego } & \multicolumn{3}{|c|}{ Mulheres } & \multicolumn{3}{|c|}{ Homens } \\
\hline & 2001 & 2013 & $\begin{array}{c}\text { Taxa } \\
\text { variação }\end{array}$ & 2001 & 2013 & $\begin{array}{c}\text { Taxa } \\
\text { variação }\end{array}$ \\
\hline Operária (o) & $\$ b 453,00$ & $\$ b 1.513,00$ & $234 \%$ & $\$ b 781,00$ & $\$ b 2.595,00$ & $232 \%$ \\
\hline Funcionária (o) & $\$ b 1.212,00$ & $\$ \mathrm{~b} 2.569,00$ & $112 \%$ & $\$ \mathrm{~b} 1.583,00$ & $\$ b 3.513,00$ & $122 \%$ \\
\hline Trabalhador (a) por conta própia & $\$ \mathrm{~b} 432,00$ & $\$ b$ 1.587,00 & $267 \%$ & $\$ b 557,00$ & $\$ b 2.024,00$ & $263 \%$ \\
\hline $\begin{array}{l}\text { Patrão, sócio ou empregador sem } \\
\text { remun. }\end{array}$ & $\$ b 953,00$ & $\$ b 3.735,00$ & $292 \%$ & $\$ b 1.985,00$ & $\$ \mathrm{~b} 4.786,00$ & $141 \%$ \\
\hline Empregada (o) doméstica & $\$ b 583,00$ & $\$ b 1.490,00$ & $156 \%$ & $\$ b 693,00$ & $\$ b 2.017,00$ & $191 \%$ \\
\hline SALÁRIO MÍNIMO & $\$ b 400,00$ & $\$ b$ 1.200,00 & $200 \%$ & $\$ b 400,00$ & $\$ b 1.200,00$ & $200 \%$ \\
\hline
\end{tabular}

TABELA 11 - Rendimento médio no trabalho principal da população ocupada por tipo de emprego (em moeda Bs\$), por sexo, para os anos de 2001 e 2013, Bolívia.

Fonte: INE/Encuestas de mejoramiento de condiciones de vida (MECOVI 1999 - 2002), Encuesta continua de hogares 2003 - 2004, Encuesta de hogares 2005 - 2013

Elaboração: SOKEN, D.

Ao comparar os valores dos rendimentos médios do ano de 2013 entre homens e mulheres da Bolívia, constata-se que apenas as ocupações de operária e funcionária apresentam desigualdade singular de 1,26 de salário mínimos para a operária e 2,14 para as mulheres que são funcionárias, enquanto que os homens que são operários recebem 2,16 salários mínimos e os funcionários 2,93. As demais ocupações correspondem a ganhos salariais mais homogêneos.

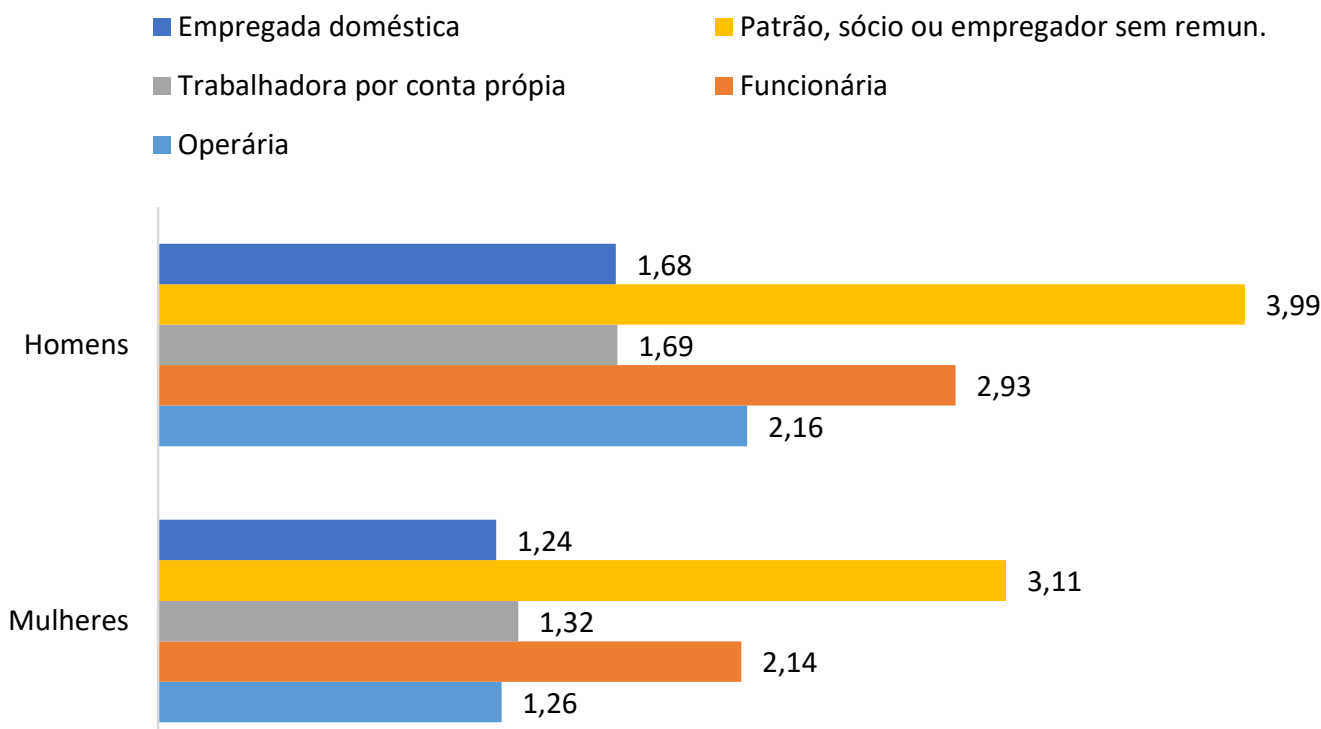

Quantidade de salário mínimo (ano de 2013)

GRÁFICO 25 - Rendimento médio no trabalho principal da população ocupada por tipo de emprego (em moeda Bs\$), por sexo, para o ano de 2013, Bolívia.

Fonte: INE/Encuestas de mejoramiento de condiciones de vida (MECOVI 1999 - 2002), Encuesta continua de hogares 2003 - 2004, Encuesta de hogares 2005 - 2013

Elaboração: SOKEN, D. 
Segundo as pesquisas do IBGE, referente aos anos de 1993 e 2002 no Brasil, observa-se que a forma de inserção da mulher no mercado de trabalho se mostra precária, com constante elevação da jornada de trabalho. Segundo essa pesquisa, as mulheres que receberam até 2 salários mínimos representaram maioria, $70 \%$ delas cumprem no mercado de trabalho jornada de trabalho de 45 a 48 horas, enquanto que, aquelas que realizaram a jornada de 49 horas ou mais representaram mais de $60 \%$.

Sem rendimento Mais de $10 \mathrm{SM} \quad 5$ a $10 \mathrm{SM} \backsim 2$ a $5 \mathrm{SM} \square$ Até $2 \mathrm{SM}$

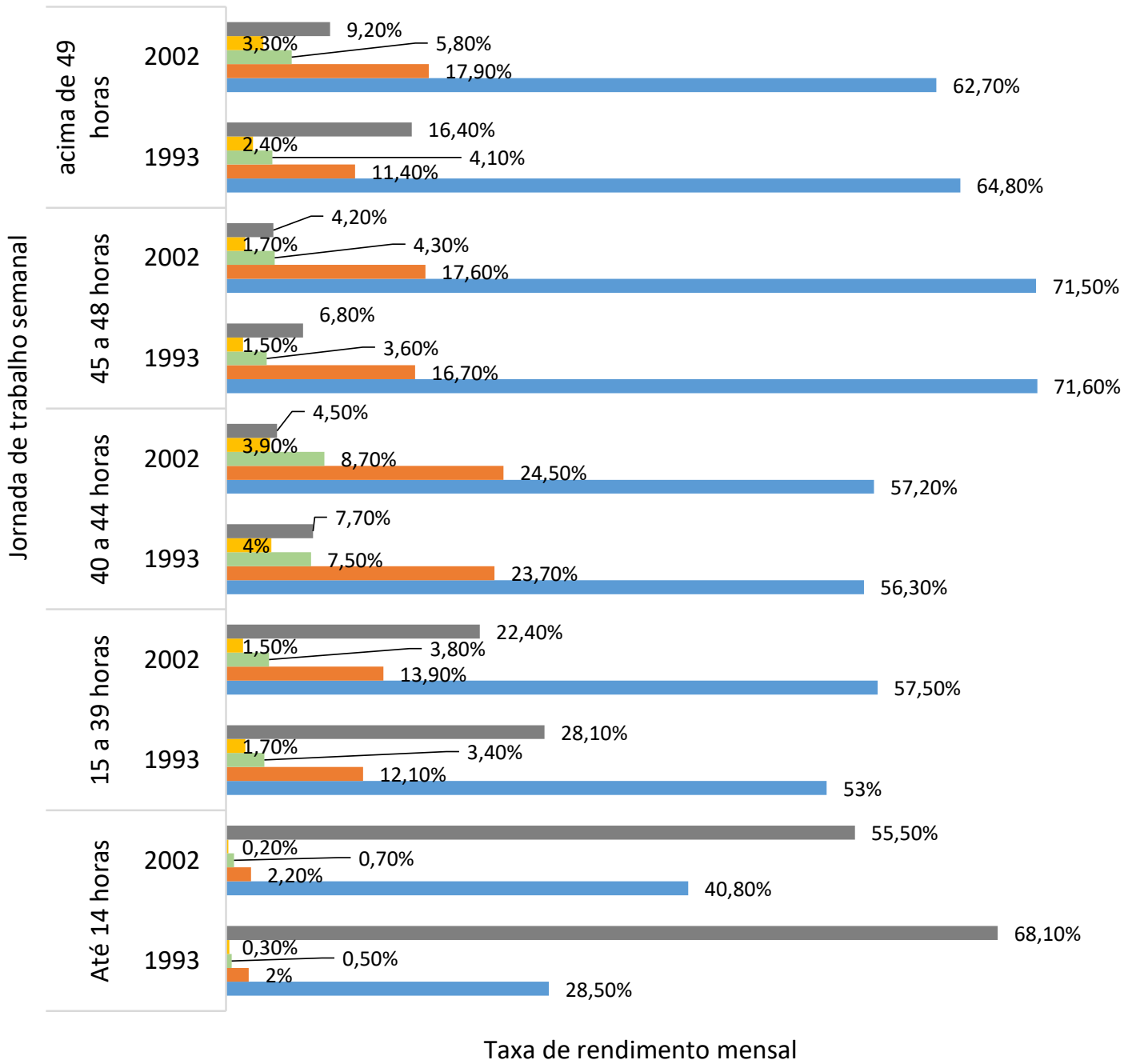

GRÁFICO 26 - Taxa feminina de rendimento mensal por jornada de trabalho semanal, segundo faixa de salário mínimo, nos anos de 1993 e 2002 - Brasil

Fonte: Brasil/IBGE/Censos demográficos

Elaboração: SOKEN, D. 
Na Bolívia, observa-se que as ocupações estão alterando a jornada de trabalho das mulheres, com base nos dados de 2000 e 2013 verifica que a maior jornada de trabalho feminina estava na ocupação de empregada doméstica que teve redução de 62,8 horas semanais para 45,7 horas. Houve queda também nas ocupações de trabalho familiar ou aprendiz sem remuneração que teve reduziu de 38,6 horas para 35,4 horas semanais.

No entanto, outras ocupações passaram a exigir maior tempo de trabalho, tais como: operária que aumentou de 41,8 horas para 45,7 horas semanais; funcionária passou de 38,3 horas para 39,5 horas semanais e aquelas que exerciam a ocupação de patroa ou sócia ou empregadora sem remuneração teve a jornada acrescida de 43,4 horas para 48,4 horas semanais.

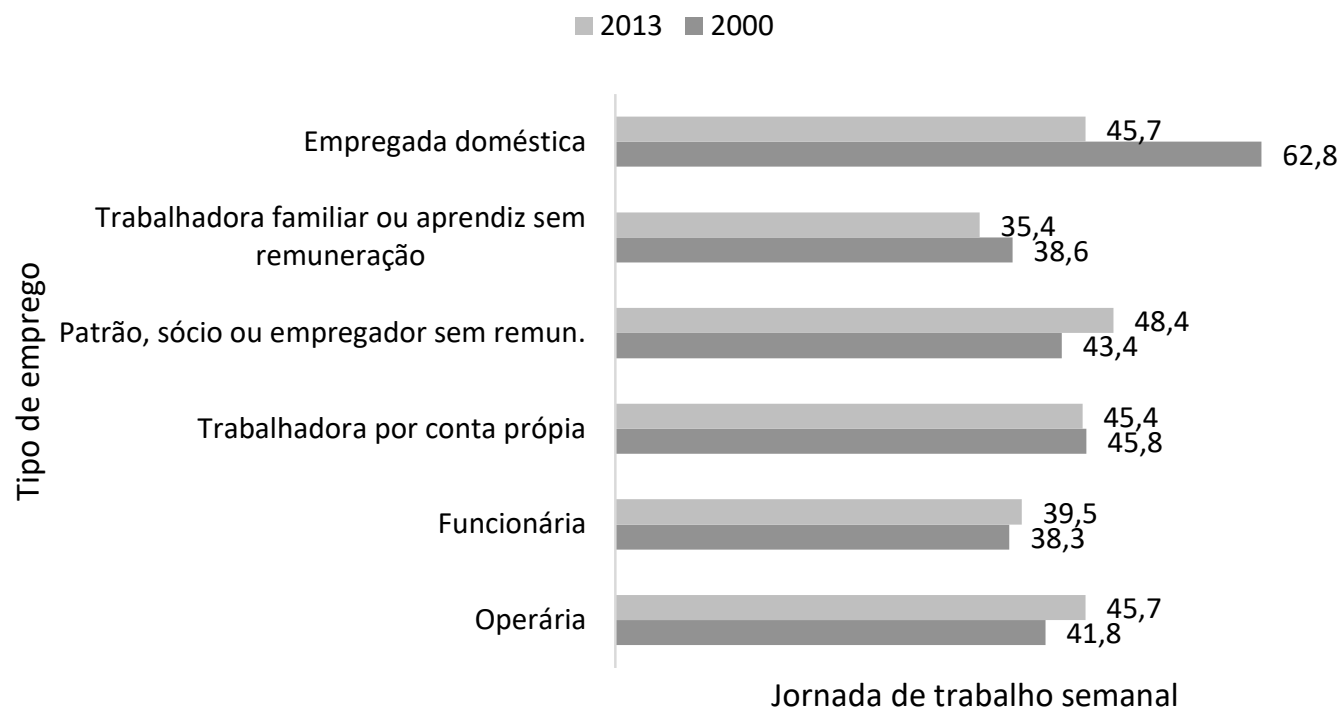

GRÁFICO 27- Média de horas semanais de jornada de trabalho das mulheres da Bolívia, segundo tipo de emprego, nos anos de 2000 e 2013

Fonte: INE/Encuestas de mejoramiento de condiciones de vida (MECOVI 1999 - 2002), Encuesta continua de hogares 2003 - 2004, Encuesta de hogares 2005 - 2013

Elaboração: SOKEN, D.

A responsabilidade nos domicílios tem sido outra variável importante para a pesquisa sobre gênero. $\mathrm{E}$ o que se tem notado é um número cada vez maior de mulheres responsáveis pelos domicílios. No Brasil, 18,1\% de mulheres eam responsáveis pelos domicílios no ano de 1991, passando para 24,9\% em 2000, isso significou o acréscimo de 4.886.367 mulheres responsáveis pelos domicílios no país. Bem como, são ainda as principais responsáveis com o cuidado dos filhos e familiares, cerca de 55,5\% são casadas e 42,7\% têm filhos (IBGE, 2002), o que representa uma sobrecarga de atividades, 
considerando-se que as mulheres dedicam mais tempo com os afazeres domésticos do que os homens.

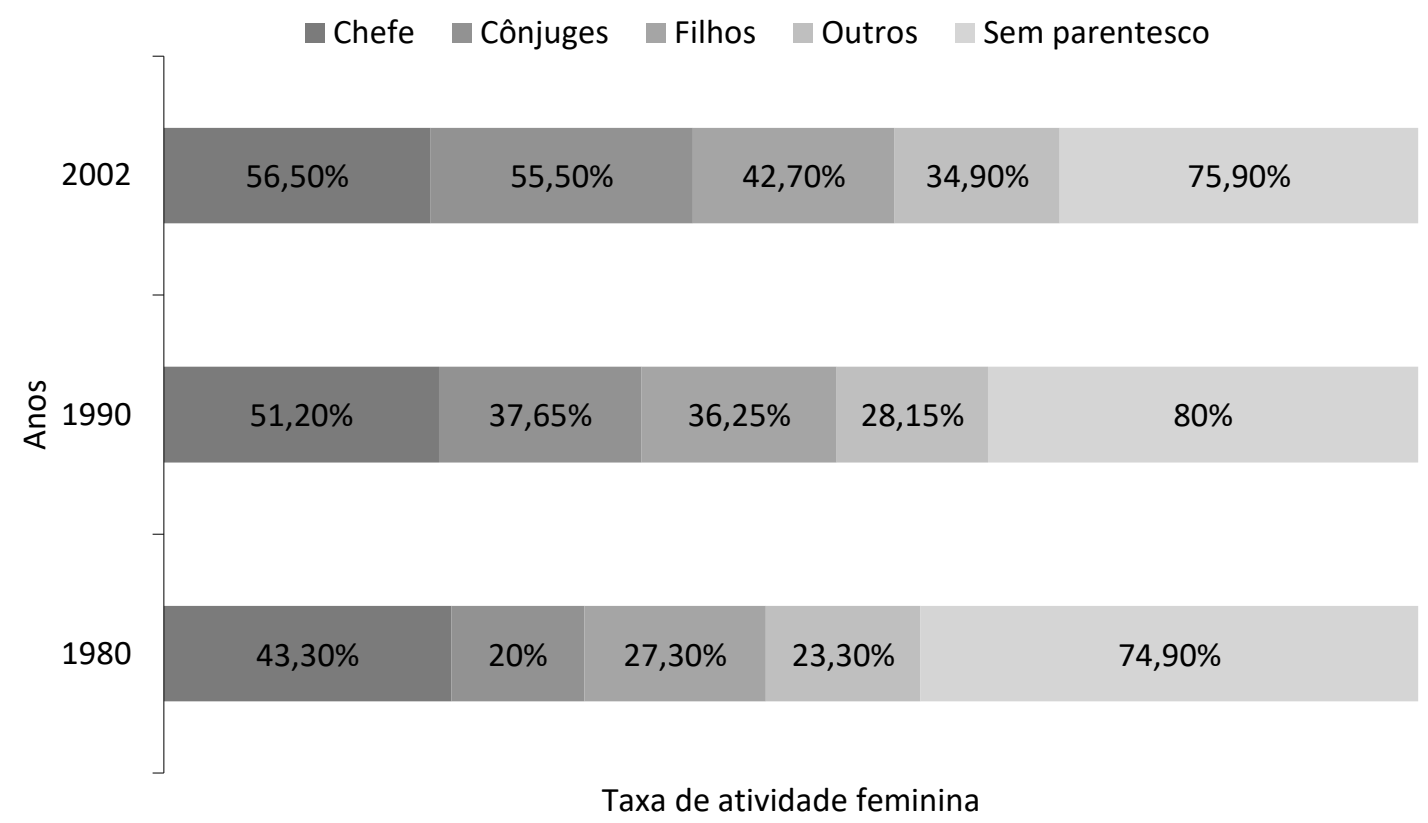

GRÁFICO 28 - Taxa de atividade feminina segundo posições na família, nos anos de 1980, 1990 e 2002 Brasil

Fonte: Brasil/IBGE/Censos demográficos Elaboração: SOKEN, D.

As extensas jornadas de trabalho na Bolívia são realizadas tanto por mulheres como por homens. Uma fatia significativa de homens e mulheres realizou a jornada de trabalho de 40 a 49 horas semanais, cerca de 30,94\% da população ocupada e 22,95\% de mulheres, significando um total de 618.903 homens e 375.718 mulheres, no ano de 1999. Já o trabalho de tempo parcial é mais significativo para as mulheres, a jornada de trabalho de 10 a 19 horas é realizada por $12,84 \%$ de mulheres contra $8,41 \%$ de homens. No entanto, estão na área urbana $28,38 \%$ de homens e $24,48 \%$ de mulheres que realizam a jornada mais elevada; permanecem por mais de 60 horas no trabalho. 


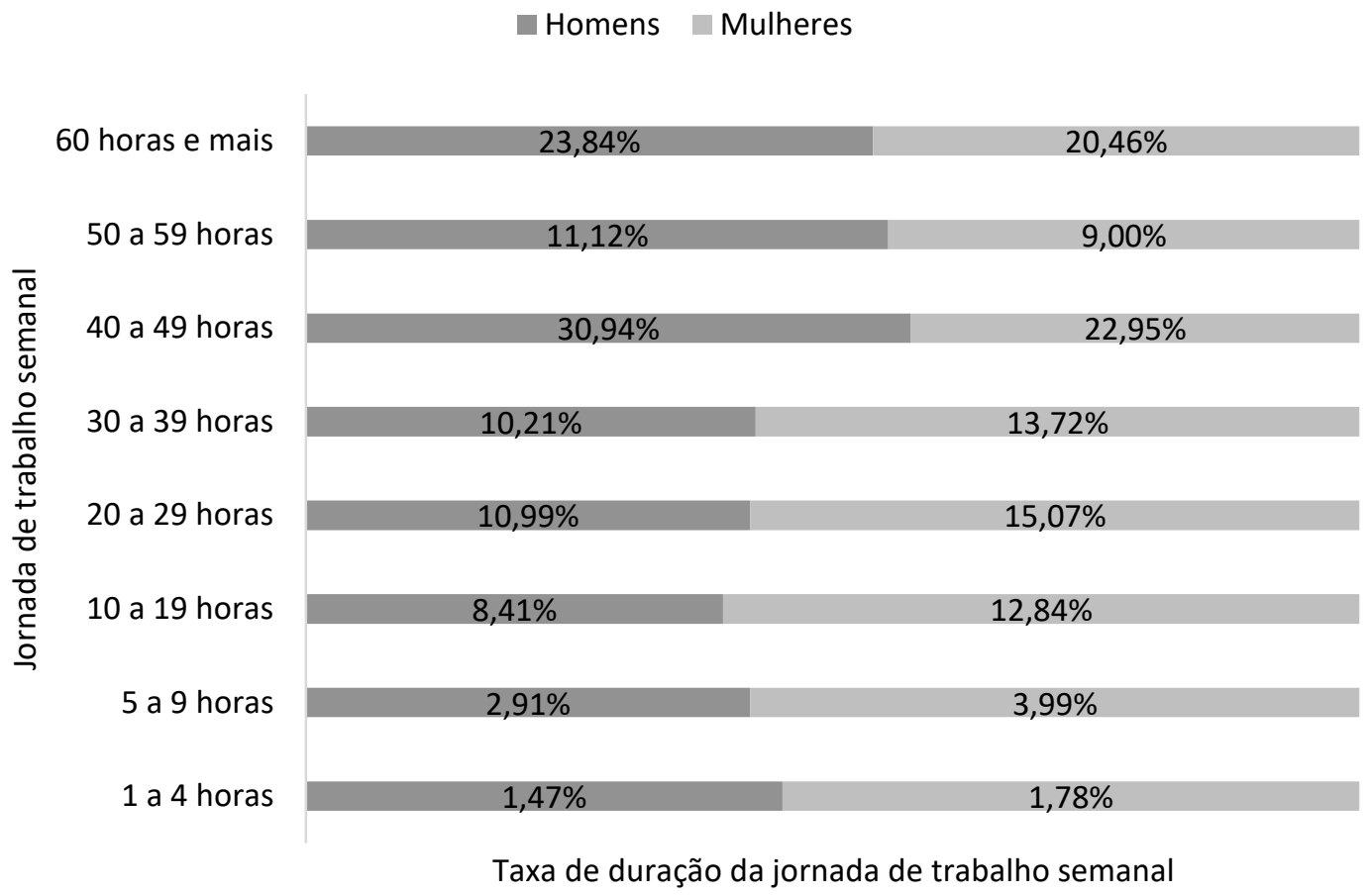

GRÁFICO 29 - Jornada de trabalho por sexo segundo pessoas ocupadas na Bolívia, no ano de 1999 Fonte: Instituto de Nacional de Estadística - Bolívia Elaboração: SOKEN, D.

As observações destacadas evidenciam que as recentes pesquisas, ao incorporarem nas estatísticas as atividades de ocupação feminina de uma forma particular, mostraram que a inserção da mulher no mercado de trabalho está diretamente relacionada à sua condição na família, considerando que poucas delas tiveram atuação em estruturas produtivas, especificamente em atividades industriais que hoje se encontram em processo de reestruturação, uma vez que isso implicaria em (des) qualificação ${ }^{70}$ do trabalho e ainda, sabe-se que essas diversas formas de impactos são diferenciadas por gênero.

Desta forma, enfatizam Matesco e Lavinas (1996) em sua pesquisa sobre a reestruturação produtiva e organizacional da indústria brasileira, que o contrato de força de trabalho feminina "parece revelar-se mais como um elemento aparador de choques atenuantes dos impactos das oscilações dos ciclos da economia e menos uma flexibilização na estrutura produtiva" (MATESCO e LAVINAS, 1996).

Portanto, pode-se considerar que os prováveis impactos dessa reestruturação produtiva nos dois países em estudo, sabendo também que a participação da mulher na atividade industrial boliviana é baixa, têm influenciado de forma mais significativa as

\footnotetext{
${ }^{70}$ BLAY, 1978.
} 
atividades tradicionais relacionadas à mão de obra masculina, que, todavia, se manifesta de forma indireta sobre a estrutura familiar.

Os impactos dessas mudanças são observados em economias que tiveram seu processo de industrialização recém implantado, tendo como efeito negativo o desemprego estrutural proporcionado pela introdução da robótica. E de forma subseqüente, verificouse que as mulheres passaram no período seguinte a participar do mercado de trabalho, as razões estariam resididas na redução da renda familiar e necessidade de garantir a sobrevivência da família.

O aumento da participação da mulher no mercado de trabalho, especialmente a partir dos anos 1990, reforça o crescimento da PEA - População Economicamente Ativa no Brasil e na Bolívia, que por motivos relacionados à redução da renda familiar ou pela necessidade de aquisição de bens e serviços para sobrevivência da família, verifica semelhanças no processo de inserção feminina no mercado de trabalho, que geralmente caracterizada como classe social menos favorecida.

Em linhas gerais, a pesquisa fez um retrato particularizado do mercado de trabalho da mulher tanto no Brasil e quanto na Bolívia e mostrou que o seu processo de inserção no mercado de trabalho tem ocorrido de maneira precarizada. A estrutura ocupacional feminina existente resultou no uso de força de trabalho de mulheres idosas, outras relacionadas às atividades domésticas de elevada jornada de trabalho e de baixo rendimento, como também a produção familiar realizada sem remuneração.

E sobretudo, verifica-se o comércio de produtos têxteis e confecções se esparrama pelo território boliviano e chega até os espaços fronteiriços a partir do uso do trabalho feminino que tem como principal característica o trabalho familiar e o baixo custo da mão de obra. 


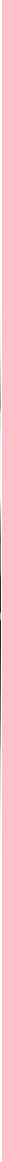

CAPÍTULO 3

A PRODUÇÃO DO ESPAÇO FEMININO: o espaço

transfronteiriço 
Neste capítulo pretende-se pensar o gênero para além da definição de papéis entre homens e mulheres. Como bem menciona Hildete Pereira de Melo e Marta Reis Castilho $(2007 \text {, p. } 4)^{71}$, é necessário ampliar o conceito de gênero ${ }^{72}$ a partir de uma abordagem transversal, que permita evidenciar a generalidade a que coube o papel da mulher na sociedade, fato ignorado pela lógica capitalista ${ }^{73}$.

Conforme discutido no capítulo anterior, a crise estrutural do capital após a Segunda Guerra Mundial impôs a reestruturação produtiva baseada no modelo flexível de acumulação, na qual a jornada padronizada de trabalho tem sido substituída pela jornada de trabalho em regime excepcional ${ }^{74}$ (DEDECCA, 2004, p. 6) ${ }^{75}$.

Para tanto, explica Dedecca (2004, p. 6) que a introdução da jornada em regime excepcional tem respaldo na população, seja pelo fato de o consumo ser vendido como lazer no caso dos shopping centers ou pela própria ampliação do ritmo e da extensão da própria jornada que impõe ao trabalhador ir às compras no fim de semana.

É fato que a jornada em regime excepcional rompe com a compatibilidade entre o tempo destinado ao trabalho com o tempo destinado à família, que de certa forma a jornada padronizada permite tal sincronização.

Percebe-se que as pesquisas sobre o uso do tempo por suas populações, segundo Dedecca (2004: p. 1), encontram dificuldades de realizar estudos em razão da escassez de

\footnotetext{
${ }^{71}$ MELO, H.P. e CASTILHO, M.R. Trabalho reprodutivo no Brasil: quem faz? IN: Textos para discussão (TD 215), junho. Niterói: Universidade Federal Fluminense/Faculdade de Economia, 2007.

${ }^{72}$ Segundo Karsten e Meertens (1992, p. 190) a complexidade da investigação no campo do gênero exige um enfoque interdisciplinar ou uma articulação de distintos aspectos e temáticas que podem aumentar os acertos na interpretação (KARSTEN, L. \& MEERTENS, D. La geografia del genero sobre visibilidad y relaciones de poder. Documents D'Anàlisi Geogràfica, 19-20, 1992, p. 181-193).

${ }^{73}$ De acordo com Chabaud e Fougeyrollas-Schwebel (1986, p. 113) "a reprodução dos trabalhadores e dos não-trabalhadores, não está inteiramente incluída na circulação das mercadorias e do capital", o que justifica a exclusão do trabalho doméstico da mulher da dimensão econômica, uma vez que a produção de indivíduos era considerada um resultado natural das relações sexuais em detrimento das relações sociais (CHABAUD, D. e FOUGEYROLLAS-SCHWEBEL, D. Sobre a autonomia relativa da produção e da reprodução. IN: KARTCHEVSKY, A. et. al. O sexo do trabalho. Rio de Janeiro: Editora Terra e Paz, 1986).

${ }^{74}$ A jornada em regime excepcional ocorre naquelas atividades econômicas que são de necessidade contínua, tais como hospitais, empresas de distribuição de energia e por imposição técnica as siderúrgicas e petroquímicas (DEDECCA, 2004, p.5)

${ }^{75}$ Segundo Deddeca $(2004$, p.6) os Estados Unidos, Inglaterra, Canadá, França e Itália são os países de maior intensidade de jornada de trabalho em regime excepcional, e os de menor intensidade são a Alemanha, Áustria, Suécia e Holanda. Em relação as atividades que adotam o regime excepcional são o comércio varejista e a atividade bancária (DEDDECA, C. Tempo, Trabalho e Gênero. IN: COSTA, A. A.; OLIVEIRA, E. M.; LIMA, M. E. B. e SOARES, V. [orgs.]. Reconfiguração das relações de gênero no trabalho. São Paulo: CUT Brasil, 2004. Disponível em: http://www.ie.ufrj.br/aparte/pdfs/nota_tecnica_tempo_trabalho_e_genero.pdf).
} 
informações. No Brasil, a categoria "uso do tempo" foi introduzida pela Pesquisa Nacional de Amostra de Domicílio (PNAD) do Instituto Brasileiro de Geografia e Estatística (IBGE) ${ }^{76}$, gerando dados estatísticos sobre o tempo despendido com afazeres domésticos. Para Dedecca (2004, p.1) esses dados possibilitam confrontar duas dimensões que são a reprodução econômica e a reprodução social. O tempo despendido com a reprodução econômica é dividido em duas partes, uma é destinada ao trabalho remunerado e outra com o deslocamento para sua realização. Já para a reprodução familiar e social é o tempo destinado para a organização domiciliar, de lazer e de sono.

Com base no ensaio teórico de Dedecca (2004, p.1) busca-se incorporar tal tema à pesquisa sobre o gênero, para se discutir as desigualdades sociais a partir da regulação sobre o uso do tempo, pois a mulher ocupa papel central na gestão do uso do tempo na sociedade capitalista.

É importante dizer que o processo industrial se apropria do trabalho ${ }^{77}$, regula o tempo ${ }^{78}$ do trabalhador, no entanto, apesar das mudanças tecnológicas, não consegue alterar o tempo destinado para a reprodução social ${ }^{79}$ (DEDECCA, 2004, p. 3 e 4).

Desta forma, é pertinente analisar a dupla jornada de trabalho da mulher, que produz "mercadoria" e reproduz "o espaço doméstico" 80 . Tal peculiaridade do mercado de trabalho feminino tem oportunizado as organizações produtivas incorporarem as mulheres em trabalho familiar e domiciliar, caso das maquilas bolivianas que estão se esparramando por toda a Bolívia, bem como a reprodução do comércio popular na

\footnotetext{
${ }^{76} \mathrm{O}$ IBGE junto a demais instituições de pesquisa vêm coordenando os debates e levantando informações sobre Uso do Tempo no Brasil, recentemente o país foi sede da $35^{\text {a }}$ Conferência Anual organizada pela Associação Internacional para a Investigação sobre o Uso do Tempo (IATUR), cujo tema foi "A contribuição econômica de mulheres e homens: workshop de capacitação em análise de dados de usos do tempo para formulação de Políticas Públicas".

77 A monetização do consumo impôs à população desprovida de meios de produção a venda de força de trabalho para viabilizar sua sobrevivência (DEDECCA, 2004, p.2)

78 "A capacidade do capitalismo de organizar o trabalho, estabelecida claramente na segunda metade do século XIX, desproveu o trabalhador do poder de controlar o tempo de trabalho, transferindo-o para a nova classe de homem responsáveis pela gerência e administração do processo produtivo (DEDECCA, 2004, p. 3)".

${ }^{79}$ A regulamentação da jornada de trabalho diária de 10 horas se deu em 1947 na Inglaterra e logo no ano seguinte na França. A data simbólica do $1^{\circ}$ de maio significa a morte de 5 operários na cidade de Chicago em 1886 por lutar pela limitação da jornada de trabalho diária (DEDECCA, 2004, p. 5)

${ }^{80}$ ROSSINI (1988, p. 163).
} 
fronteira que tem como motor de acumulação a mão de obra feminina organizada pelas famílias.

Com base na pesquisa de livre-docência da Professora Doutora Rosa Ester Rossini (1988, p. 163) sobre "Geografia e Gênero: A mulher na lavoura canavieira paulista", compreende-se que os estudos da família sempre estiveram atrelados à estrutura patriarcal, e coube ao papel da mulher a subordinação ao homem. Portanto, nos diz Rossini (1988) que:

o espaço do homem é bastante distinto do da mulher. Poder-se-ia dizer que o
espaço de dentro regula a posição da mulher e do trabalho na família brasileira.
O cuidar das crianças, da casa, das compras, da escola são reservados à mulher,
pois neste espaço se incluem não só a casa mas sua extensão econômica, isto é,
o espaço da economia doméstica (ROSSINI, 1988, p.163).

Entende-se que o trabalho familiar na atividade agrícola sempre foi uma condição de redução de custos com a mão de obra. Sob o regime de colonato a chefia da família coube a autoridade do homem, tinha por função organizar as atividades das crianças e da mulher, conforme diagnosticou Rossini (1988, p.164), "às crianças, o cuidado dos pequenos animais e da colheita e à mulher os trabalhos domésticos, a produção dos valores de uso, cultivo da roça de subsistência e a colaboração na colheita do café". Além disso, menciona Rossini (1988, p. 165) que o pagamento era definido pelo número de “enxadas", portanto, a produtividade da unidade familiar dependia do tamanho da prole.

No que diz respeito à organização do mercado de trabalho capitalista, constata-se a partir da pesquisa de Rossini (1988, p. 158 a 168), que o assalariamento do trabalho restringiu o tempo que a família destinava à produção doméstica, onde cada membro teve que usar o tempo do trabalho reprodutivo para trabalhar em outra atividade remunerada e assim dar conta da sobrevivência da família ou mesmo para formar a própria. No entanto, o trabalho doméstico continuou sendo produzido, até o momento pela mulher, já que na família não há divisão sexual do trabalho.

É importante dizer que o assalariamento também alterou a organização da família, pois agora cada trabalhador assalariado recebe um rendimento individual e a mulher e os filhos são considerados não mais uma mão de obra necessária e sim, uma despesa doméstica (ROSSINI, 1988, p. 165). 
Além disso, Rossini (1988, p.167) chama a atenção para o processo de migração do campo para as cidades, onde a família tenta se reproduzir com os ganhos das atividades rurais-urbanas, uma vez que o campo se tecnifica e faz uso da mão de obra volante. Na maioria das vezes os ganhos dos salários não suprem as despesas domésticas, que agora se traduzem em consumo das famílias e não mais produtos provenientes do trabalho doméstico.

Conforme mencionaram Chabaud e Fougeyrollas-Schwebel (1986, p. 114, 115 e 117) apesar do trabalho doméstico ser uma destinação do lugar da mulher na sociedade industrial, ela não está isenta do trabalho assalariado. No entanto, observam que quando essa mulher exerce uma atividade assalariada isso resulta em configuração espaço-tempo, ou seja, há uma necessidade de compatibilizar atividade profissional com o trabalho doméstico. Portanto, "o tempo da mulher caracteriza-se pela fragmentação e pela superposição das tarefas".

Sobretudo, a vida profissional da mulher sofre a concorrência daquelas instituições que são a extensão do trabalho doméstico, tais como creche, escola, clínica médica, hospital, posto de saúde, as quais impõem horários que segundo Calió (1992, p.89) implicam em aprofundamento da contradição entre o trabalho de fora e dentro-decasa.

Sendo assim, a própria divisão capitalista do trabalho estabelece a diferença da inserção da mulher no mercado de trabalho, que sempre dá prioridade ao trabalho doméstico (CHABAUD e FOUGEYROLLAS-SCHWEBEL, 1986, p. 121).

A seguir, buscou-se a explicação por meio da abordagem geográfica sobre o trabalho produtivo e reprodutivo da mulher e como essa mulher organiza e elabora seu próprio espaço. Para isso, foram selecionados alguns textos das décadas de 1980 a 1990, períodos em que se reuniu o maior número de bibliografias sobre a pesquisa de gênero em geografia. 


\title{
3.1. Questões teóricas e metodológicas sobre o espaço feminino a partir do olhar geográfico
}

Segundo levantamento bibliográfico realizado por Calió (1991, p. 21), verificouse que "a produção feminista na geografia teve início praticamente a partir dos anos oitenta, sobretudo, em estudos que abordavam a divisão sexual e espacial do trabalho e seu impacto na vida privada e pública das mulheres".

As principais correntes teóricas do pensamento feminista que influenciam os estudos sobre geografia de gênero, de acordo com Calió (1991, p. 15 a 17) são derivadas das vertentes "liberal", "socialista", "radical" e "pós-modernista" e que de certa forma tem contribuído para enriquecer o pensamento geográfico.

Informa André (1990, p.336) que foi:

\begin{abstract}
A partir do final dos anos setenta, a questão do gênero começou a ganhar relevo na investigação geográfica, em particular no Reino Unido. Esse interesse relaciona-se claramente com a importância que tem sido atribuída à situação desfavorecida das mulheres por parte das instituições internacionais e, designadamente, da ONU: em 1975, realizou-se na Cidade do México, a Conferência Mundial do Ano Internacional da Mulher, onde não só se manifestou o alerta para determinadas situações sociais consideradas inaceitáveis como ficou também esboçado um conjunto de medidas e intervenções a desenvolver pelas Nações Unidas; em 1979, a Assembleia Geral aprovou a Resolução 34/180, que deu origem à Convenção para a Eliminação de todas as formas de discriminação contra as mulheres; em 1980, e em 1985, realizaram, respectivamente as conferências Mundiais de Copenhaga e de Nairobi, onde se concretizou e desenvolveu o empenhamento internacional no sentido de combater a exclusão social das mulheres (ONU, 1989, apud ANDRÉ, 1990, p.336) ${ }^{81}$.
\end{abstract}

No entanto, a maior contribuição foi do grupo feminista de tendência socialista que se formou em 1982 na Inglaterra cuja perspectiva de estudos considerava temas tanto sobre as relações sociais de gênero no espaço quanto aos usos sociais do espaço com atributos de 'feminilidade' e de 'masculinidade', denominados de "Women and Geography Study Group - WGSG" e os principais trabalhos foram das fundadoras BOWLBY, MACKENZIE e FOORD (1982) "Feminism and Geography" e o livro “Geography and Gender” publicado em 1984 considerado o marco nos estudos de gênero na Geografia (CALIÓ,1991, p.23 e 24; GARCIA-RAMON, 1989, p.11).

${ }^{81}$ ANDRÉ, I.M. O GÊNERO EM GEOGRAFIA. Introdução de um novo tema. Lisboa: Finisterra, XXV, 50, 1990, p.331-348. 
Segundo Joan $\operatorname{Scott}^{82}$ (1990, p.32), para as feministas marxistas a explicação material para o gênero pode se desdobrar em duas análises. Pelo sistema dual capitalismo e patriarcado - que explicaria a opressão à mulher por meio da interação dos sistemas, e outra, a marxista ortodoxa, que explica pelo modo de produção capitalista a origem da mudança nos sistemas de gênero organizados a partir da divisão sexual do trabalho, sendo a família, os lugares e a sexualidade produtos do modo de produção transformados. Para elas a causa econômica é prioritária e o patriarcado se desenvolve e muda em função das relações de produção. Sendo assim, acreditam que é necessário transformar a divisão do trabalho por sexo para acabar com a dominação masculina.

Em linhas gerais a estrutura do pensamento feminista aborda as diferenças de gênero e conferem às relações entre mulheres e homens uma situação de poder e prestígio social desiguais e, a partir desse ponto explica-se a posição de inferioridade e desvalorização da força de trabalho feminina. Sendo assim, Maria Dolores Garcia Ramon expõe que a geografia pode contribuir para as discussões sobre gênero, pois considera que tanto as desigualdades entre gêneros quanto as relações de poder não se manifestam de forma homogênea no território (GARCIA-RAMON, 1985, p136) ${ }^{83}$.

Além disso, Garcia-Ramon (1989, p.9) ${ }^{84}$ critica alguns estudos de geografia de gênero anglo-saxônica que separam a análise da geografia econômica da geografia social, sendo que segundo Garcia-Ramon, a desigualdade social não está na distribuição e no consumo, mas sim, na organização da produção.

Dentre outros avanços teóricos estão os estudos feministas que buscam superar aquele esquema metodológico que valoriza apenas o trabalho produtivo - considerado somente o que produz mercadorias e, portanto, subvaloriza o trabalho feminino, que, por sua vez, é esse que se desdobra na produção informal de mercadorias e na reprodução da força de trabalho. Constata Garcia-Ramon, (1989, p.9 a 10) uma forte interconexão entre as esferas da produção e reprodução.

A partir de uma perspectiva marxista sobre a geografia e gênero, Rossini (1988, p. 2, 3, 4, 7, 10, 16, 42 e 289), explica que a produção e reprodução da vida na construção

\footnotetext{
${ }^{82}$ SCOTT, J. El genero: una categoria util para el analisis historico. IN: Historia y gênero. Las mujeres en la Europa Moderna y contemporánea. Instituto Valenciana D’estudis i investigació, 1990.

${ }^{83}$ RAMON-GARCIA, M. D. El análisis de genero y la geografia: reflexiones en torno a un libro reciente. IN:Documents d'Analisi Geografica, 6, 1985, pp. 133-143

${ }^{84}$ RAMON-GARCIA, M. D. Genero, espacio y entorno: hacia una renovacion conceptual de la Geografia? Una introduccion. IN: Documents d'Analisi Geografica 14, 1989, pp. 7-13
} 
do espaço é uma questão de gênero, portanto, as mulheres reunidas com a família exercem funções imprescindíveis à produção e reprodução da força de trabalho, garantindo a reprodução do capital.

Para o pensamento feminista 'radical' a opressão e desvalorização social do trabalho feminino assume uma relação direta com o sistema patriarcal que mediante poder político e ideológico do homem sobre a mulher estabelece "leis, rituais, tradição, linguagem, costumes, educação e a divisão de trabalho" (CALIÓ, 1991, p. 54; GARCIARAMON, 1985, p.136).

Para tanto, observa Calió (1991, p. 3), "o gênero pode ser identificado a partir dos vários espaços em que ele se constrói: a família, o mercado de trabalho, as instituições, a subjetividade (...)".

Desta forma, Karsten e Meertens (1992, p.185) chama a atenção para a relação entre a divisão do trabalho em função do gênero e subordinação feminina, uma vez que os papéis que mulheres e homens desempenham na sociedade não são homogêneos, pois dependem não somente do gênero, mas também de outros princípios como, classe e etnicidade, que resultaram em construções ideológicas da 'feminilidade' e 'masculinidade'.

As autoras centram suas pesquisas em novos estudos de geografia de gênero, como a relação entre o trabalho produtivo e reprodutivo ${ }^{85}$ e as relações de poder no interior da unidade doméstica. Focam em análises dos processos de tomada de decisões, introduzem elementos dinâmicos com conceito de ciclo de vida da família e ressaltam a interação entre percepção e realidade dos papéis do gênero tanto em âmbito familiar como no produtivo (GARCIA RAMÓN, 1988; STOLCK, 1986; WILSON, 1985 apud KARSTEN e MEERTENS,1992, p.185).

\footnotetext{
${ }^{85}$ Segundo Karsten e Meertens (1992, p.184) o trabalho produtivo e reprodutivo tem sido tema de vários estudos sobre a mulher, destacam-se as correntes liberais que elaboram o debate a partir da igualdade entre homem e mulher no mercado de trabalho, consideram que a conquista de uma melhor posição sóciotrabalhista da mulher haverá uma justa divisão das tarefas domésticas. Já as feministas radicais buscam explicar a origem da subordinação feminina mediante o controle masculino sobre seu trabalho, portanto, a libertação dessa dominação implicaria em uma nova valorização do trabalho feminino. E por fim, a corrente feminista socialista relaciona o problema da subordinação feminina com a produção capitalista cuja reprodução é assegurada pelo trabalho feminino, sendo assim, para alcançar a libertação feminino deve-se articular a luta de gênero com a luta de classe (FOORD \& GREGSON, 1986; MCDOWELL, 1986; BENERÍA \& SEN, 1981 apud KARSTEN E MEERTENS, 1992, p.184)
} 
De acordo com Vaiou (1992, p. 125), a maneira como se organiza a vida diária determina as possibilidades e condições de mulheres e homens de trabalhar e viver em diferentes contextos.

Karsten e Meertens (1992, p.186) criticam o determinismo macroeconômico que, segundo elas, de certa forma tenta explicar por variáveis exógenas a vida das mulheres, bem como sua condição de 'vítima' das estruturas da sociedade numa perspectiva neomarxista ou por uma via liberal oferecendo novas oportunidades de educação.

Introduzem outras questões a serem incorporadas aos novos estudos que questionam a dicotomia clássica do espaço público e privado, onde a vida pública representada pelos homens e a privada pelas mulheres está sendo falseada pelo fato de as mulheres se apresentarem como atores sociais, com papel ativo na vida produtiva e reprodutiva da sociedade (KARSTEN e MEERTENS,1992, p.186) ${ }^{86}$.

Para Garcia-Ramon (1985, p.138), essa dicotomia espaço público e privado dificilmente será modificada, pois se a divisão social do trabalho está vinculada ao desenvolvimento do espaço urbano, onde a mulher exerce dupla função de trabalho doméstico e assalariado, qualquer possibilidade de mudança deverá ocorrer no plano das novas tecnologias.

Para fins de discutir a natureza do espaço feminino da fronteira entre as cidadesgêmeas de Corumbá, Puerto Quijarro e Puerto Suarez tratou-se de compreender as origens das práticas comerciais realizadas pelas mulheres do comércio popular de fronteira. Verificou-se no capítulo anterior que a atividade comercial é parte constitutiva do espaço econômico dessas mulheres, por meio do qual elas garantem a produção e reprodução do espaço transfronteiriço.

Como a maioria das mulheres que pratica a atividade comercial na fronteira veio do interior da Bolívia, onde a base cultural é Aymara, pretende-se analisar essas relações de trabalho com base na cultura indígena boliviana, para então, descrever as formas comerciais de institucionalização no território.

\footnotetext{
${ }^{86}$ As pesquisas de geógrafos e geógrafos sobre gênero caminham no sentido de analisar as distintas formas do "atuar feminino", a investigação se dirige cada vez mais para a mulher como ator social, seja no Terceiro Mundo ou na Europa (KARSTEN e MEERTENS,1992, p.186).
} 
Desta forma, a partir das práticas comerciais Aymara buscou-se descrever como se dá no espaço essa organização comercial na fronteira, onde as mulheres conseguem aliar o tempo para a produção e para a reprodução social, aliás é a capacidade da mulher em operacionalizar a atividade comercial que faz dela importante articuladora dos arranjos territoriais da fronteira.

\subsubsection{O espaço das mulheres Aymaras no comércio}

As raízes da cultura comercial andina são derivadas da atividade agrícola das comunidades ${ }^{87}$ Aymaras, distribuídas entre os territórios boliviano, peruano e chileno. A cultura Aymara data de épocas pré-incaicas, sobreviveu ao período inca e posteriormente ao período colonial espanhol e ao republicano (YAPITA MOYA, 1980 apud HARDMAN, 1988, p. 211)

O calendário agrícola regula o trabalho da comunidade, que se desdobra entre o plantio e a colheita, onde a organização do trabalho é familiar e após a produção cabe à mulher realizar o comércio do excedente agrícola (CARTER e ALBÓ, 1988, p. 474).

As mulheres Aymaras de $\mathrm{La} \mathrm{Paz}^{88}$ são consideradas comerciantes de primeira, a elas são delegadas a responsabilidade de gastar o dinheiro da família, elas gastam sem consultar seus maridos o que não acontece com eles que precisam consultar suas esposas. A comunidade Aymara reconhece a habilidade das mulheres de "hacer el truque de sus productos", que significa vender os produtos agrícolas (por exemplo, chuños, oca, papa, habas, kaya, etc) utilizando como medida as duas mãos juntas, denominada de phuxtu, e realiza a troca com outra medida usando o q'upi, novelo de lã, ou seja, vendem por punhados e recebem em fardos (HARDMAN, 1988, p. 196).

\footnotetext{
${ }^{87}$ Segundo Carter e Albó (1988, p. 451; 474), trata-se de comunidade onde o território é dividido por determinadas unidades familiares que produz de forma individual, denominadas de ayllu ou jatha. $\mathrm{O}$ primeiro é formado por unidades familiares que se agrupam em um território contínuo ou descontínuo (ayllu); o segundo (jatha) é um grupo de pessoas com relações de parentesco que formam uma unidade social com acesso comum a terrenos, bens e obrigações.

${ }^{88}$ A Calle Huyustus na cidade de La Paz é um grande centro de distribuição do comércio popular para o país. Organizado por pequenas famílias de origem Aymara formam associações que cooperam entre si para custear viagens comerciais onde apenas um representante se encarrega de realizar a compra para várias pessoas; se reúnem para fazer pedidos às empresas da Zona Franca de Iquique que devem alcançar valores acima de 100.000 dólares para obter desconto de 5\% (TASSI, 2013, p.176 e 177)
} 
A organização do trabalho é feita pelo chefe da família, a ele cabe a distribuição da jornada de trabalho. A relação de trabalho acontece pelo sistema de ajuda que pode ser recíproca ou não, denominado de yanapa (sem reciprocidade) e ayni (com reciprocidade), o que reforça os laços familiares. Existe outro tipo muito comum mink'a que é o pedido de ajuda ou colaboração que se paga com o que tiver no momento, pode ser em dinheiro ou produto agrícola ou mesmo com comida e bebida abundante. Há outros que são mais generosos do que recíprocos, como o sathaqa ou chiki, o primeiro trata-se de oferecer uma lavoura e o segundo se refere a um pedaço de terra, geralmente oferecem a um amigo, parente ou pessoa que está passando por necessidades (CARTER e ALBÓ, 1988, p. 474 a 476).

O trabalho, os recursos e os produtos também podem ser divididos, denomina de waki que significa parte ou porção. Se for trabalho agrícola dividem os recursos: o dono da propriedade oferece as terras e o outro as sementes e ambos realizam o trabalho (CARTER e ALBÓ, 1988, p. 475).

A produção agrícola, a pecuária e o artesanato Aymara estão organizados por inúmeras instituições de reciprocidade que dão conta de distribuir todos os bens entre os vários grupos que se dividem em regiões, níveis da elite governamental e unidades domésticas da comunidade (CARTER e ALBÓ, 1988, p. 452).

A mulher Aymara quando se casa herda uma parte das terras da mãe, o filho herda parte das terras do pai. Ao estar em matrimônio trabalha junto com o marido para cultivar suas terras e a dele com culturas independentes o que lhes rende uma produção diversificada. Um dado curioso é que a mulher casada recebe o sobrenome da mãe e o filho carrega o do pai (HARDMAN, 1988, p. 196).

O matrimônio significa uma importante passagem para a vida adulta do povo Aymara, quando uma pessoa se casa firma um compromisso com a comunidade de prestação de serviços que se renova a cada ano, todo chefe de família passa por uma série de funções desde as mais onerosas até de mais prestígio. Aquele que não passa por estas fases é considerado um yuqalla, pessoa imatura, que não atingiu a plena condição humana como jaqi, que significa pessoa (CARTER e ALBÓ, 1988, p. 480).

O que chama atenção dessa forma de organização social é o fato de atribuições de serviços à comunidade também pode expressar um exercício de poder. Para as funções 
que exigem uma certa urgência e demandam recursos financeiros a comunidade nomeia aqueles que possuem maiores condições econômicas ou a outros que querem demonstrar sua gratidão aos que já realizaram tais funções. A exceção do sacerdote que é selecionado pelos poderes sobrenaturais, expressados pelos raios (CARTER e ALBÓ, 1988, p. 480).

Essas comunidades originárias passaram por adequações após a reforma agrária de 1953. Dentre os ajustes estão as funções que deram origem à organização sindical campesina que se põe em confronto ao modelo de fazendas nas regiões norte do país. A hierarquia funcional estabelece a autoridade máxima da comunidade a função de jilaqata, tal supremacia é atingida quando o indivíduo ascende a todos os caminhos até a plena maturidade. O jilaqata pode permanecer na função até sete anos ou mais, suas obrigações como autoridade e representante da comunidade incluem desde oferecer hospitalidade até recolher impostos de contribuição territorial das comunidades e repassar as autoridades estatais. Sobretudo deve intermediar conflitos, julgar casos legais, determinar direitos de herança, supervisionar o comércio de bens e de moeda. Portanto, sua função é de representante e intermediário entre a comunidade e as autoridades de fora (CARTER e ALBÓ, 1988, p. 482).

De acordo com Carter e Albó (1988, p. 490) as comunidades Aymaras desempenham o papel de "mini-estado", tem seu próprio território, seus cidadãos, suas próprias normas, sua estratificação interna, seu sistema de autoridades, sua organização interna de recursos materiais e humanos, sua relação corporativa com outras comunidades e com o mundo exterior. Portanto,

La población racial de este país está compuesta por los Aymara, Quechua, Tupiguaraní, "mestizos" y criollos, además de otras muchas naciones Indias em las selvas orientales. Por esta razón es un país plurilíngue y multicultural, en el cual la mayoría nacional es Aymara, Quechua y de otras nacionalidades indígenas (YAPITA MOYA, 1980 apud HARDMAN, 1988, p. 206). 


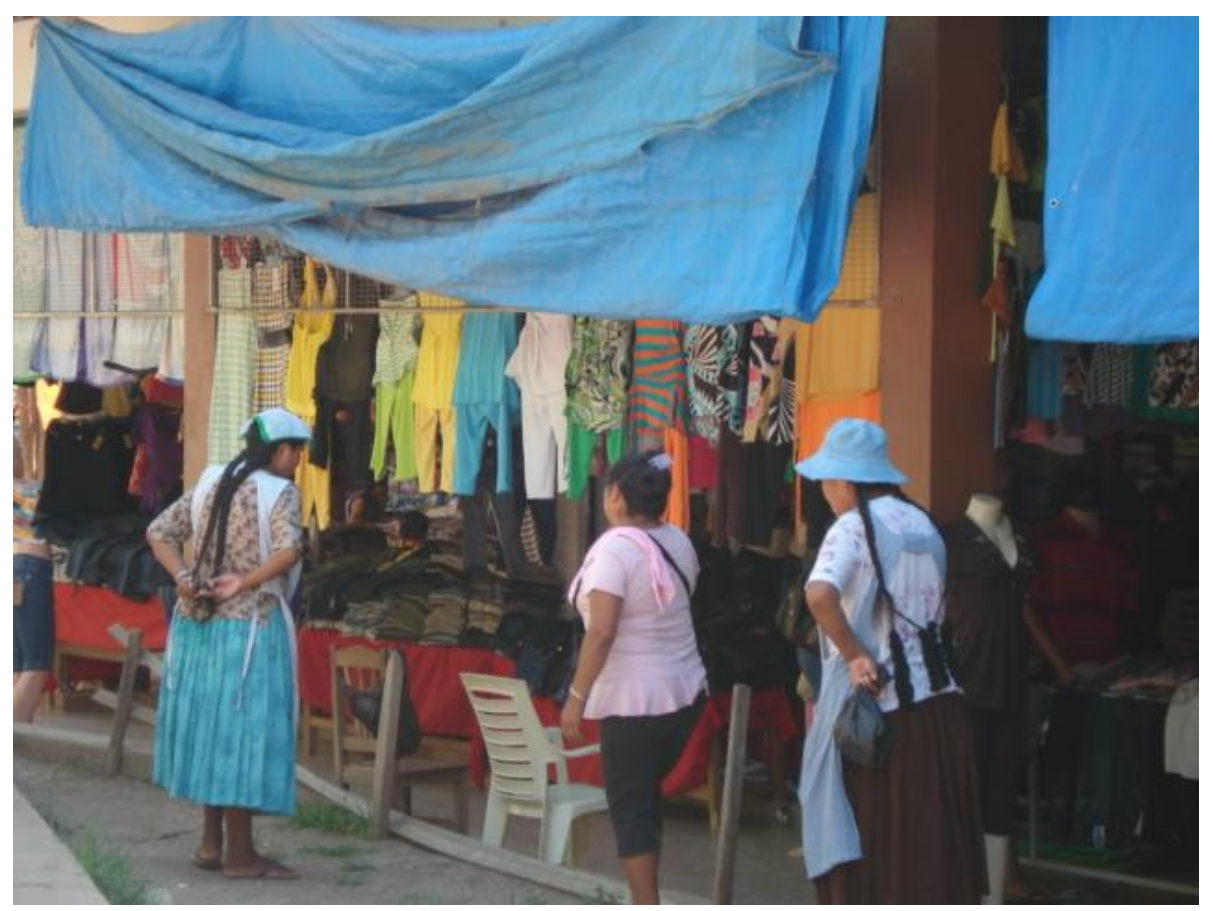

FOTO 13 - Bolívia, Arroyo Concepción em Puerto Quijarro. Mulheres indígenas no comércio popular da fronteira.

Foto: SOKEN, D., agosto de 2008

É comum na linha da fronteira encontrar mulheres do altiplano com trajes típicos indígenas, circulando por toda a área comercial e sempre oferecendo algo para vender. Cita-se uma passagem de HARDMAN (1988), que de certa forma sintetiza a vitalidade dessas mulheres no comércio:

La mujer de pollera podemos sentarnos al lugar que encontremos espacio para vendernos algo, no buscamos comodidade.

Vergüenza no debe existir, uno para alimentarse vende lo que encuentra(HARDMAN, 1988, p. 196).

De acordo com a versão atualizada de Carter e Albó (1988, p. 475), pode-se dizer que dentre as relações de trabalho prevalecem as formas de exploração, por exemplo, o ayni converte em empréstimos com altos juros; a mink'a se refere à contratação de mão de obra barata; o waki significa a ruptura entre os que oferecem o capital ou os insumos ou o terreno ou o trabalho, pois essas partes estão ora fora da comunidade ou totalmente alheias a ela.

A seguir, com base nos questionários e entrevistas realizados na área da pesquisa, pretende-se descrever o espaço feminino da fronteira. Cabe mencionar que 153 mulheres responderam ao questionário da pesquisa, 90 do lado brasileiro e 63 do lado boliviano. $\mathrm{O}$ questionário foi aplicado nos dias 15 a 23 de março de 2013. As mulheres que 
concederam entrevistas gravadas totalizaram 21, sendo 17 do lado boliviano e 04 do lado brasileiro. O período das entrevistas foi de 01 a 10 de setembro de 2014.

\subsubsection{A produção do espaço transfronteiriço das cidades-gêmeas Corumbá, Puerto Quijarro e Puerto Suarez: uso da mão de obra feminina.}

Conforme discutido no capítulo anterior, o comércio popular ${ }^{89}$ andino se espalha por toda a Bolívia e encontra nas fronteiras bolivianas estratégias peculiares de acumulação mercantil. Considera-se então, que essas associações familiares formadas por pequenos comerciantes vão estabelecer novas relações comerciais na fronteira entre Brasil e Bolívia.

Estima-se que existam cerca de dois milhões de comerciantes autônomos (informais) na Bolívia, o que configura o país que tem o maior nível de informalidade no mundo, está acima de 65\%. Segundo a OIT, dados de 2004, calcula que o emprego informal alcança $67 \%$ do emprego total na Bolívia, isso não é nada bom para as mulheres, pois apenas $10 \%$ da PEA feminina (dados de 2009 da OIT e PNUD) no país têm acesso a benefícios e seguridade social (TASSI et al, 2013, p. 67)

A informalidade na Bolívia parece ser um fenômeno estrutural da economia do país, pois ao contrário de outras economias que encontram nas atividades informais respostas para a crise, na Bolívia esse tipo de emprego se expande quando o ocorre o crescimento econômico, unidades produtivas familiares querem aproveitar as oportunidades para ingressar nos setores populares (TASSI et al, 2013, p.68).

O comércio popular na Bolívia é tão atrativo que faz surgir um outro fenômeno, o pluriemprego, por tratar de indivíduos que atuam em outras áreas como professores, motoristas, estudantes, policiais, que dividem o objetivo de complementar a renda e aproveitar o boom do crescimento econômico atuando como comerciantes em tempo parcial ou descontínuo, comerciantes de final de semana ou de período de férias (TASSI et al, 2013, p. 68)

\footnotetext{
${ }^{89}$ Os autores Tassi et al $(2013$, p. 58) compreendem que o conceito de "setor informal" é insuficiente para caracterizar a presença majoritária de sujeitos econômicos de vontade própria que atuam em todos os setores da economia boliviana, portanto, utilizam do conceito de "economia de base popular", cujo propósito é analisar as estratégias e reconhecer a autoria desses atores populares.
} 
Desta forma, a fim de operacionalizar a pesquisa, foram adotados os seguintes critérios para delimitar o tipo de estabelecimento a ser pesquisado, o estabelecimento que adota métodos de burocratização para realizar as transações comerciais e outros que adotam métodos caseiros para realizar negócios; por tipo de consumo, se varejo ou atacado; popular ou para o turismo de compras.

Levando em consideração o perfil das cidades-gêmeas, foram selecionados alguns setores onde a atuação das mulheres no mercado de trabalho é relevante pesquisar, tais como vestuário, alimentação, cosméticos e eletrônicos. Conforme o questionário aplicado, 102 mulheres desenvolvem atividades comerciais em ambos os lados da fronteira, sendo 45 do lado brasileiro e 57 do lado boliviano.

No setor industrial foi possível listar apenas duas atividades, a mineração e panificação, das quais participam 05 mulheres. Já a atividade de serviços teve maior participação do lado brasileiro, ao todo 40 mulheres, contra apenas 06 do lado boliviano. Tal fato pode ser observado pela maior quantidade do setor em Corumbá, onde se destacam: escolas, creches, restaurantes, hotéis, salões de beleza, hospital, gestão municipal, bancos e empresa de transportes.

\begin{tabular}{|c|c|c|c|}
\hline \multirow{2}{*}{ Setor pesquisado } & \multicolumn{2}{|r|}{ Lugar da pesquisa } & \multirow[b]{2}{*}{ Total } \\
\hline & Corumbá & Puerto Quijarro/Puerto Suarez & \\
\hline Comércio Varejista & 45 & 57 & 102 \\
\hline Serviços & 40 & 6 & 46 \\
\hline Indústria mineração & 3 & 0 & 3 \\
\hline Indústria alimentícia & 2 & 0 & 2 \\
\hline Total & 90 & 63 & 153 \\
\hline
\end{tabular}

TABELA 12 - Total de mulheres distribuída em Corumbá, Puerto Quijarro e Puerto Suarez, por setor pesquisado. Período de abrangência corresponde a 15 a 23 de março de 2013.

Fonte: Questionário 04 (Perfil socioeconômico)

Elaboração: SOKEN, D., março de 2013.

No que diz respeito ao nível de rendimento pessoal, verificou-se diferenças entre o valor nominal do salário mínimo nas localidades pesquisadas. Ao abordar as comerciantes sobre o valor do salário mínimo, foram levantados os seguintes valores: no Centro Comercial 12 de Octubre o salário mínimo médio era de US\$ 58,30 (cinquenta e oito dólares e trinta centavos), no Shopping Puerto Aguirre o valor médio variou entre US\$ 131,20 (cento e trinta e um dólares e vinte centavos) e US\$ 145,77 (cento e quarenta 
e cinco dólares e setenta e sete centavos $)^{90}$. Em Corumbá o salário mínimo era equivalente a US\$ 300,00 (trezentos dólares) ${ }^{91}$.

Considerando que os valores dos salários mínimos são distintos entre as áreas pesquisadas, foi registrada a faixa salarial que cada mulher contabilizou como ganho mensal. É relevante dizer que na atividade comercial, a faixa salarial de 1 a 2 saláriosmínimos teve maior destaque, no entanto, como a maioria é autônoma a renda auferida pode variar.

\begin{tabular}{|c|c|c|c|c|c|c|c|}
\hline \multirow[b]{2}{*}{ Setor pesquisado } & \multicolumn{6}{|c|}{ Faixa de salário mínimo } & \multirow[b]{2}{*}{ Total } \\
\hline & 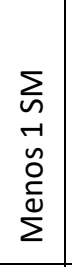 & $\begin{array}{c}\sum_{n} \\
N \\
0 \\
-1\end{array}$ & $\begin{array}{l}\sum_{n} \\
\text { N } \\
\infty \\
\sim \\
N\end{array}$ & $\begin{array}{l}\sum \\
\text { n } \\
0 \\
0 \\
0 \\
0 \\
\text { n }\end{array}$ & 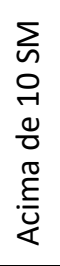 & 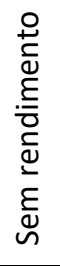 & \\
\hline Comércio-vestuário & 5 & 26 & 9 & 1 & 0 & 2 & 43 \\
\hline Comércio-perfumes & 0 & 6 & 6 & 0 & 0 & 0 & 12 \\
\hline Comércio-calçados & 0 & 5 & 0 & 1 & 0 & 0 & 6 \\
\hline Comércio-eletrônicos & 2 & 4 & 7 & 0 & 0 & 0 & 13 \\
\hline Comércio-alimentos & 0 & 7 & 3 & 0 & 0 & 0 & 10 \\
\hline Comércio-medicamentos & 0 & 2 & 0 & 0 & 0 & 0 & 2 \\
\hline Comércio-veículos & 0 & 5 & 1 & 0 & 0 & 0 & 6 \\
\hline Comércio-livros & 0 & 2 & 0 & 0 & 0 & 0 & 2 \\
\hline Comércio-construção civil & 0 & 2 & 2 & 0 & 0 & 0 & 4 \\
\hline Comércio-diversos & 3 & 0 & 1 & 0 & 0 & 0 & 4 \\
\hline Serviços & 1 & 26 & 13 & 5 & 1 & 0 & 46 \\
\hline Indústria mineração & 0 & 0 & 2 & 1 & 0 & 0 & 3 \\
\hline Indústria alimentícia & 0 & 2 & 0 & 0 & 0 & 0 & 2 \\
\hline Total & 11 & 87 & 44 & 8 & 1 & 2 & 153 \\
\hline
\end{tabular}

TABELA 13 - Total de mulheres segundo faixa de salário-mínimo distribuído por setor pesquisado. Período de abrangência corresponde a 15 a 23 de março de 2013.

Fonte: Questionário 04 (Perfil socioeconômico)

Elaboração: SOKEN, D., março de 2013.

\footnotetext{
90 Os salários na Bolívia são pagos em moeda corrente, Bs\$ (bolivianos), mas para facilitar a análise realizamos a conversão dos valores em moeda americana.

91 A moeda americana está cotada em R\$ 2,26 (reais) e Bs\$ 6,86 (bolivianos), conforme BACEN em 08/07/2013.
} 
Observou-se que a concentração da faixa salarial de 1 a 2 salários-mínimos ocorre tanto em Corumbá como em Puerto Quijarro e Puerto Suarez, que correspondeu a 49 mulheres do lado brasileiro e 38 do lado boliviano.

\begin{tabular}{|c|c|c|c|c|c|c|c|}
\hline \multirow[b]{2}{*}{ Lugar pesquisado } & \multicolumn{6}{|c|}{ Renda pessoal } & \multirow[b]{2}{*}{ Total } \\
\hline & $\begin{array}{l}\sum \\
\text { n } \\
-1 \\
\tilde{n} \\
0 \\
\frac{C}{0} \\
\sum\end{array}$ & $\begin{array}{l}\sum \\
\sim \\
N \\
0 \\
-1\end{array}$ & $\begin{array}{l}\sum_{n} \\
\text { n } \\
0 \\
N\end{array}$ & $\begin{array}{l}\sum \\
n \\
0 \\
+1 \\
0 \\
n\end{array}$ & $\begin{array}{l}\sum \\
\tilde{1} \\
0 \\
-1 \\
0 \\
0 \\
\frac{\pi}{E} \\
\frac{E}{U}\end{array}$ & 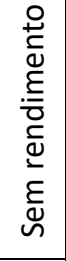 & \\
\hline Corumbá & 8 & 49 & 25 & 6 & 1 & 1 & 90 \\
\hline Puerto Quijarro/Puerto Suarez & 3 & 38 & 19 & 2 & 0 & 1 & 63 \\
\hline Total & 11 & 87 & 44 & 8 & 1 & 2 & 153 \\
\hline
\end{tabular}

TABELA 14 - Total de mulheres segundo faixa de salário-mínimo distribuída em Corumbá, Puerto Quijarro e Puerto Suarez, período de abrangência corresponde a 15 a 23 de março de 2013. Fonte: Questionário 04 (Perfil socioeconômico)

Elaboração: SOKEN, D., março de 2013.

No que diz respeito aos locais da pesquisa, em Puerto Quijarro (Bolívia) realizouse o levantamento de informações em três localidades específicas, foram elas: o Shopping de Puerto Aguirre, a Avenida Luis Salazar de la Vega e o Centro Comercial "12 de Octubre". Nas duas primeiras localidades o consumo está direcionado para o turismo de compras, a venda maior é de produtos importados do ramo de cosméticos, eletrônicos, bebidas, calçados esportivos, vestuário, decoração, artigos de pesca entre outros. Já no "12 de Octubre, a venda está voltada para a revenda e consumo de produtos populares. Nesse local, as "sacoleiras" e as atacadistas bolivianas são as principais agentes de distribuição. 


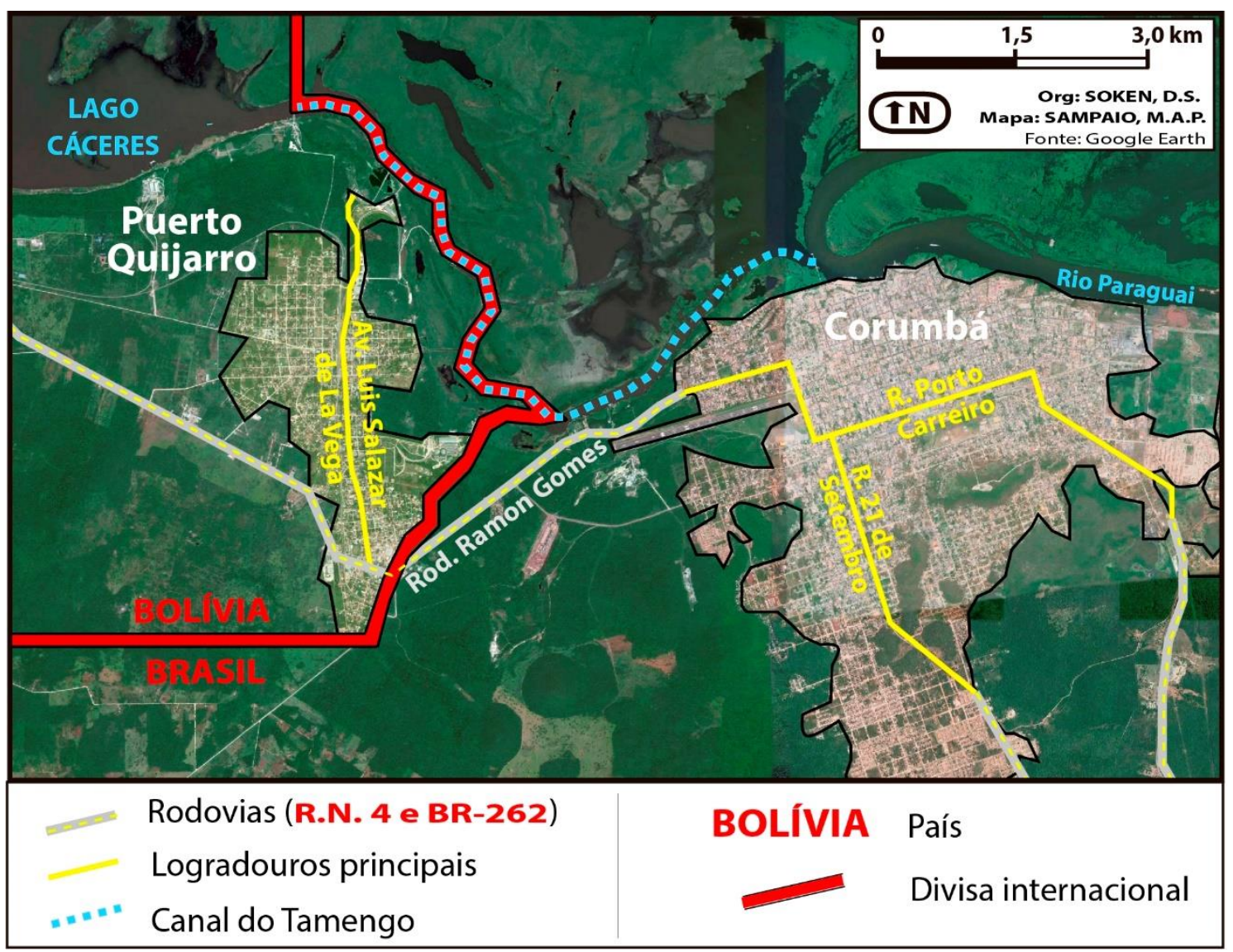

FIGURA 4 - Bolívia, Puerto Quijarro, imagem de satélite da avenida Luis Salazar de La Vega.

Organização: SOKEN, D.S.

Elaboração: SAMPAIO, M.A.P

Fonte: Google maps, 2015

O Shopping de Puerto Aguirre ${ }^{92}$, criado em 21 de fevereiro de 1991, está situado na área portuária de 206 hectares com acesso ao Canal do Tamengo, denominado de Puerto Aguirre, esse é o primeiro porto boliviano que tem saída para o mar através dos rios Paraguai e Paraná. Conforme entrevista com a administradora do Shopping, salientase no ano de 2008 existiam cerca de 44 lojistas, sendo $80 \%$ constituídos são empresários brasileiros (corumbaenses) e palestinos, os demais são paraguaios, indianos, bolivianos e outros. E no ano de 2013, verificou-se que apenas 10 lojistas atuam nesse centro comercial, cuja maioria são empresários corumbaenses.

\footnotetext{
92 Puerto Aguirre situado na província de Gérman Bush possui aproximadamente uma população de 2000 habitantes. Acesso em 24/09/2008, www.puertoaguirre.com
} 


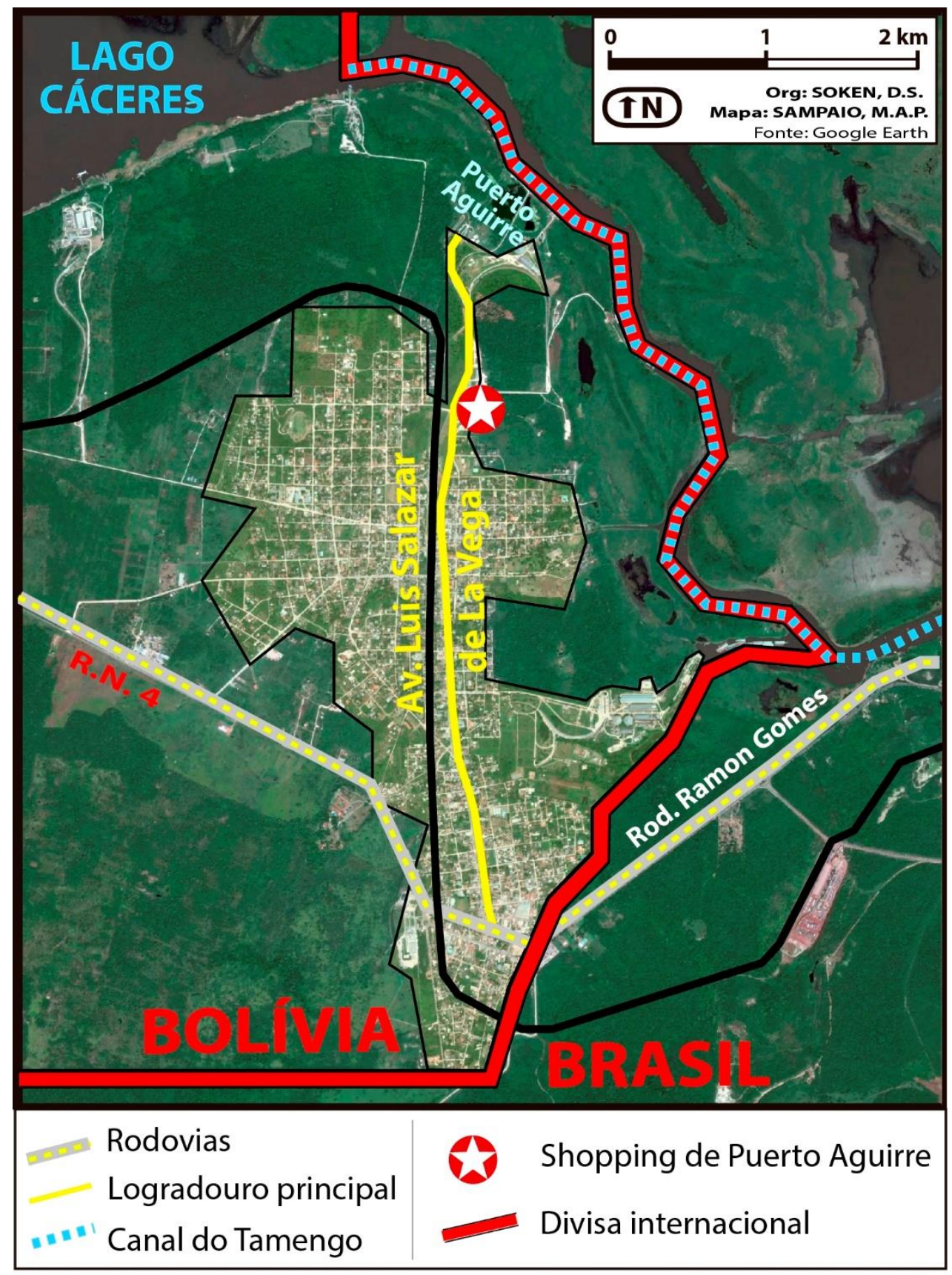

FIGURA 5 - Bolívia, Puerto Quijarro, avenida Luis Salazar De La Vega, imagem de satélite do Shopping de Puerto Aguirre.

Organização: SOKEN, D.S.

Elaboração: SAMPAIO, M.A.P

Fonte: Google maps, 2015

Com base nas entrevistas observou-se que empresários brasileiros que aportam capital no comércio da fronteira realizam em momentos distintos da taxa de câmbio, o que favorece a duplicidade de negócios nas cidades-gêmeas da fronteira. O comércio da fronteira depende da variação da moeda americana em relação a moeda brasileira, quando o dólar está alto é bom do lado brasileiro, quando está baixo é melhor do lado boliviano 
Sobretudo, muitos se instalam no lado boliviano pois considera que a burocracia sobre o comércio é mais fácil do que do lado brasileiro. Com base nas entrevistas, constatou-se que esses empresários consideram que no Brasil existem vários pontos que dificultam a organização do trabalho de comerciantes, de prestadores de serviços e de industriais, tais como a tributação que além de ser elevada é complexa e está dispersa em vários documentos.

Em relação a uso da mão-de-obra brasileira percebe-se que a maioria dos empresários evidencia os altos custos e falta de oportunidades do lado brasileiro que restringem a oferta de trabalho, bem como, apontam que as causas trabalhistas vêm onerando essa mão-de-obra. Além disso, as atividades incorrem em processos burocráticos de certificações e autorizações que são demorados e sofrem reajustes tarifários muito acima da média dos períodos.

Até o momento, encontra-se no comércio do Shopping Aguirre famílias de origem palestina que atuam na fronteira boliviana desde 1987 e se instalaram no Shopping no ano de 1992. Onde comercializam produtos importados procedentes dos Estados Unidos, Panamá e Peru. Segundo sr. N. M. ${ }^{93}$, o comércio de importados na fronteira com o Brasil é vantajosa porque as barreiras tributárias brasileiras implicam em preços mais competitivos dos produtos importados pela Bolívia, uma vez que o sistema tributário boliviano onera menos as mercadorias importadas. Portanto, observa-se que o comércio de importados da Bolívia estabelece níveis de complementação do lado brasileiro, os preços dos produtos importados estão atrelados além da variação do câmbio da moeda americana também as taxas e tributação brasileira.

Na Bolívia a tabela de tributação varia conforme os gravames, que de acordo com o tipo de mercadoria há diferentes taxas de recolhimento, por exemplo: Imposto sobre o Valor Agregado (IVA) recolhe a taxa de 13\% e Imposto sobre Consumo Específico (ICE) varia de $2 \%$ a $10 \%$ conforme o produto.

Atualmente o Shopping de Puerto Aguirre atende na sua maioria turistas brasileiros e é um dos locais de distribuição de produtos importados provenientes da

\footnotetext{
${ }^{93}$ Entrevista com sr. N.M. realizada em 04 de setembro de 2014 em Puerto Aguirre. Ele é empresário do comércio de importados no Shopping Aguirre e em Arroyo Concepción e trabalha com a esposa no setor de perfumes, produtos de decoração, bebidas, relógios, alimentos entre outros produtos importados.
} 
cidade de Santa Cruz de La Sierra, tal cidade é especializada em serviços de importação de produtos da China, Panamá, EUA e Chile e é responsável pela distribuição de produtos para todas as fronteiras bolivianas. No geral, o segmento dos produtos comercializados no Shopping segue a linha de produtos de vestuário e calçados de marcas, eletrodomésticos, jóias e relógios, bebidas alcóolicas, artigos de pesca, artesanatos e utilidades domésticas.

Os lojistas do Shopping Aguirre adotam alguns critérios para contratação de mão de obra feminina, tais como: somente por indicação de pessoas conhecidas; exigem cordialidade e atenção ao público; capacidade de comunicação em língua portuguesa. Em contrapartida, as mulheres que buscam emprego no Shopping Aguirre são atraídas pelos valores dos salários, bem como, pela regularidade do pagamento; pelo pouco esforço físico e pelo vínculo afetivo entre lojistas e funcionários.

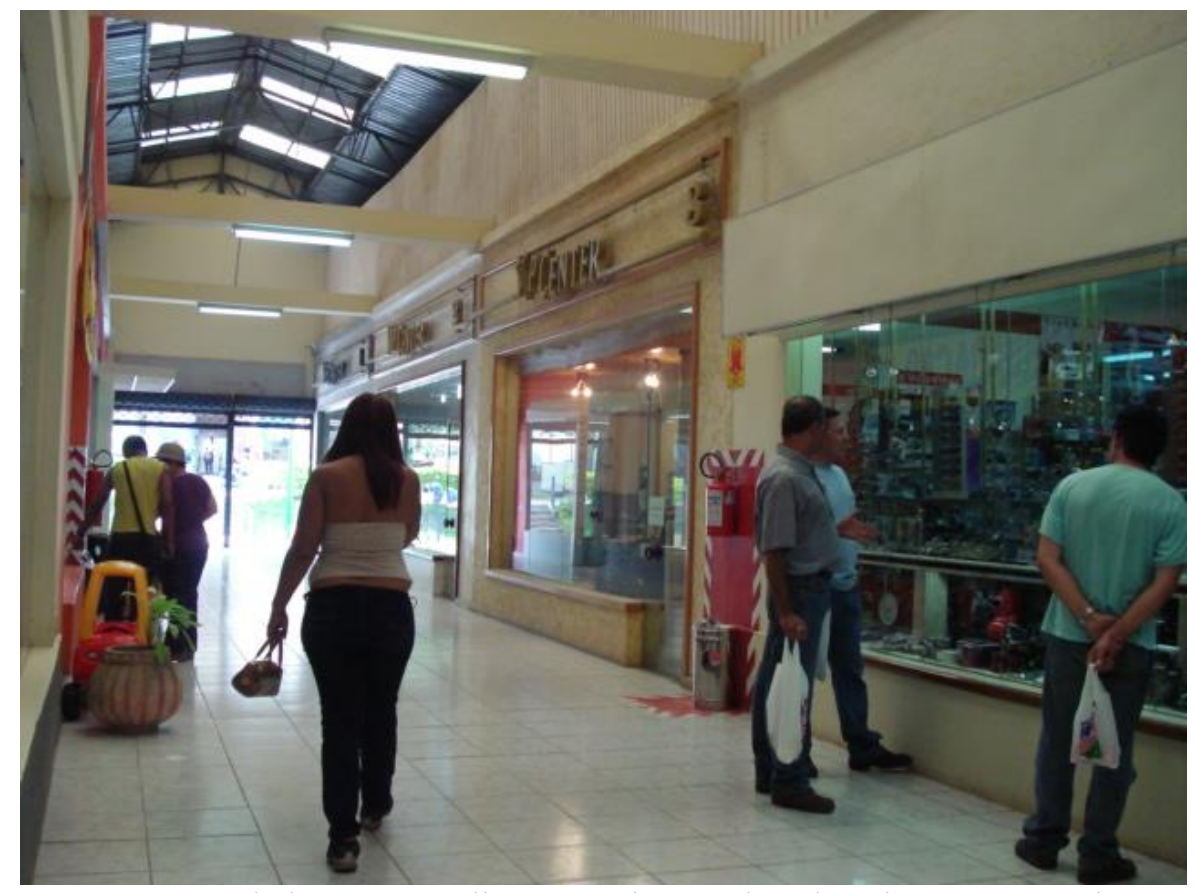

FOTO 14 - Bolívia, Puerto Quijarro, área interna do "Shopping Puerto Aguirre". Foto: SOKEN, D., março de 2013.

O Centro Comercial "12 de Octubre" está localizado próxima à linha de fronteira na cidade de Puerto Quijarro, especificamente em Arroyo Concepción ${ }^{94}$, e foi fundado

\footnotetext{
${ }^{94}$ Arroyo Concepción fundada em 1936 foi criada pelo Decreto Lei 2330 de 15 de fevereiro de 2002 e está localizada na Segunda Seção Municipal de Puerto Quijarro e tem aproximadamente 5000 habitantes. Essa comunidade está a $4 \mathrm{~km}$ de Corumbá e $645 \mathrm{~km}$ de Santa Cruz de La Sierra, capital do departamento boliviano
} 
em 12 de outubro de $1980^{95}$. Trata-se de uma associação de comerciantes varejistas e atacadistas, cuja maioria proveniente das cidades de La Paz, Oruro, Cochabamba e Santa Cruz forma uma rede de comércio popular que coordena toda a distribuição de produtos importados diretamente da China para as fronteiras bolivianas. Popularmente conhecido por "Feirinha" ou "Shopping Chão", o Centro Comercial "12 de Octubre” foi inicialmente formado por cerca de mil comerciantes que se instalaram precariamente, próximos à linha da fronteira e vendiam produtos eletrônicos importados entre outros produtos chineses a céu aberto.

${ }^{95}$ Conforme entrevista realizada em 20/09/2008 com o Sr. Jaime Merúvia, presidente do Centro Comercial 12 de Octubre. 


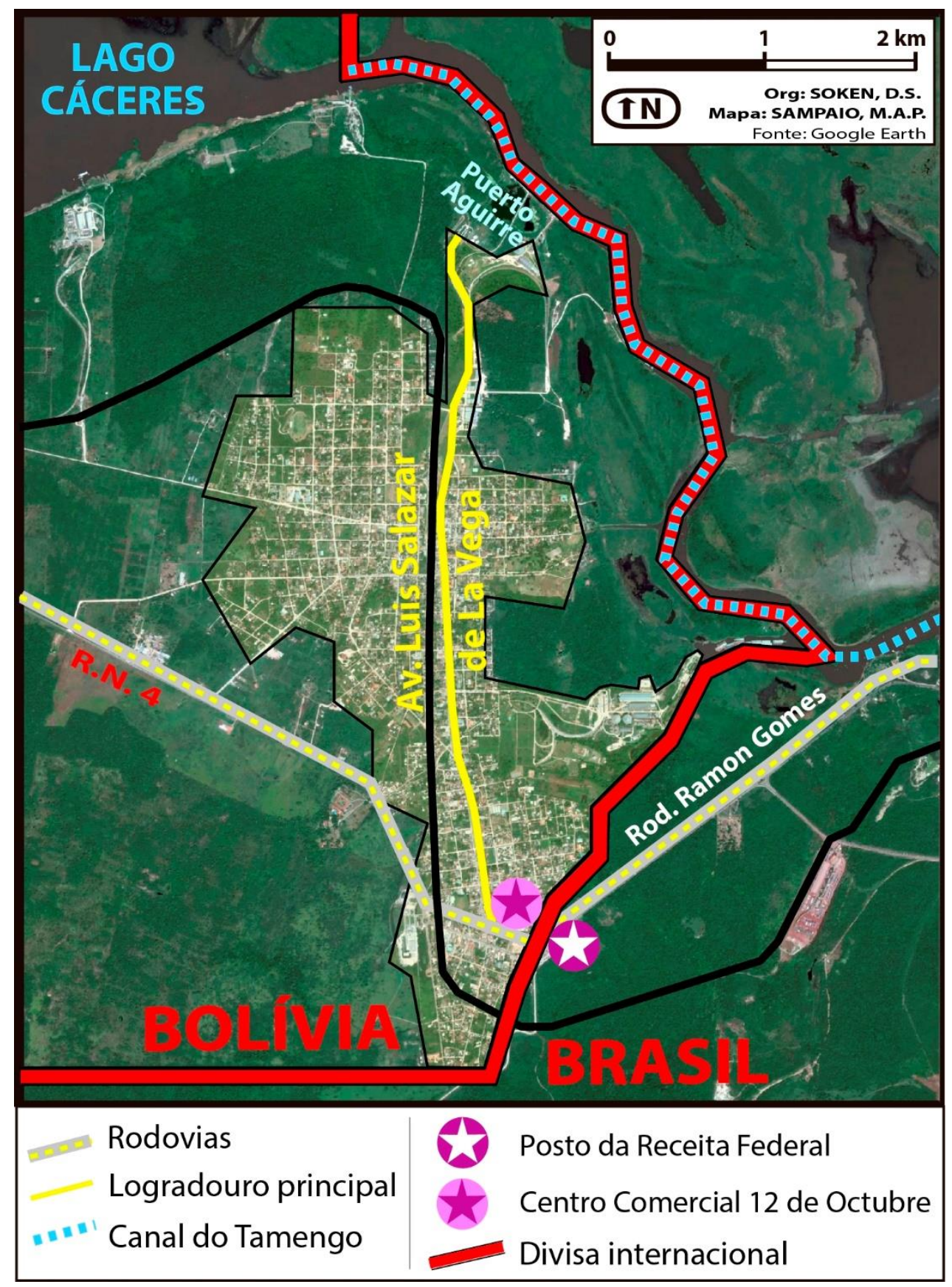

FIGURA 6 - Bolívia, Puerto Quijarro, avenida Luis Salazar De La Vega, imagem de satélite do Centro Comercial 12 de Octubre (Feirinha da Bolívia) e demais estabelecimentos comerciais da linha de fronteira.

Organização: SOKEN, D.S.

Elaboração: SAMPAIO, M.A.P.

Fonte: Google maps, 2015

Em meados da década de 1990 muitos comerciantes retornam para o interior da Bolívia e os poucos que restaram, cerca de uns duzentos comerciantes adquiriram terreno próximo da linha de fronteira e iniciaram a construção do prédio do atual Centro Comercial. 
Uma característica comum do Centro Comercial 12 de Octubre é a predominância de mulheres bolivianas à frente dos negócios de compra e venda, elas formam pequenos grupos de atacadistas e varejistas especializadas no setor de confecção. No entanto, existe uma divisão sexual do trabalho nesse segmento quando se trata de casal. Cabe ao homem o trabalho de carregar e transportar a mercadoria até o local de comercialização- a maioria faz frete para a fronteira - e a mulher se responsabiliza em atender o público, buscar informações sobre quais produtos são mais vendidos, barganhar na negociação com os fornecedores e viajar para realizar compras até as cidades do interior da Bolívia e/ou para o centro comercial popular da cidade de São Paulo.

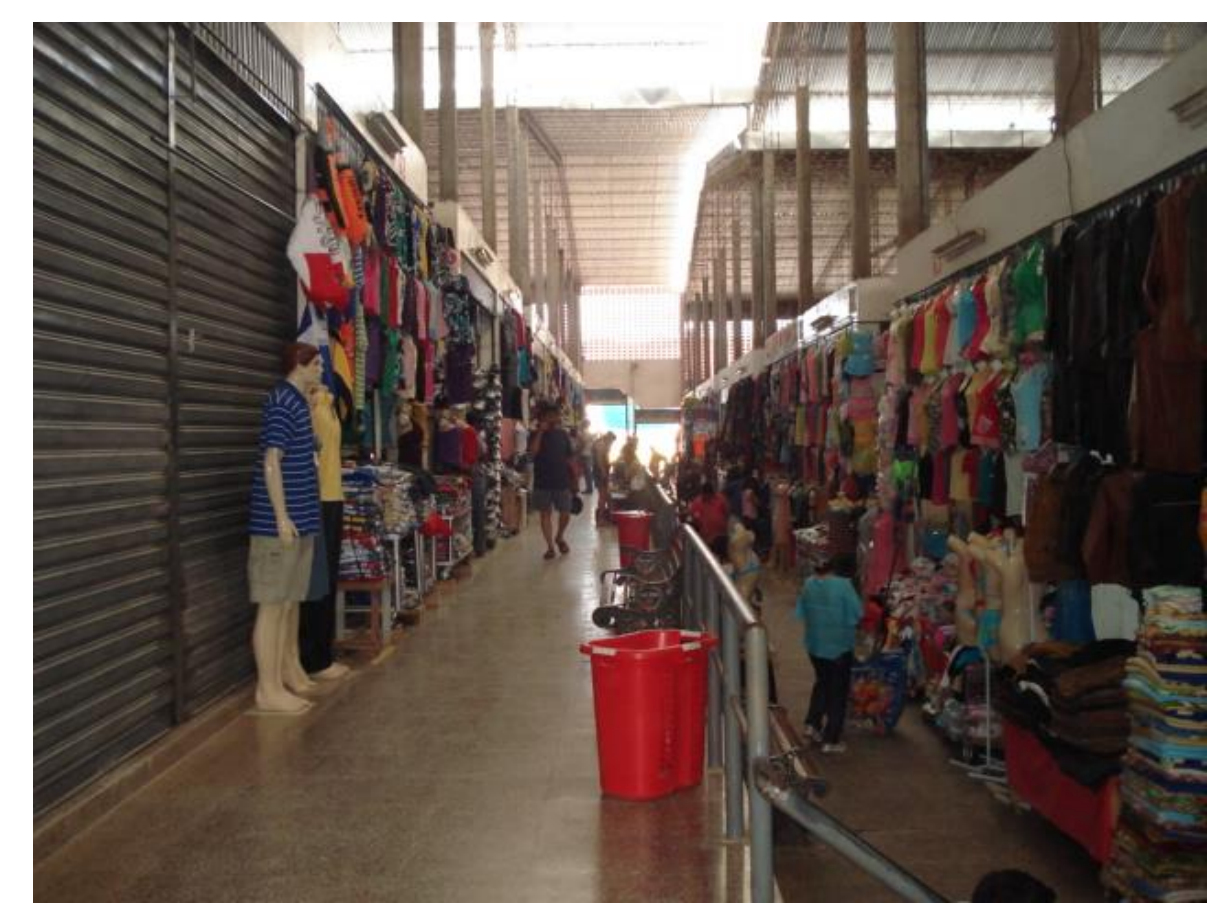

FOTO 15 - Bolívia, Puerto Quijarro, área interna do "Centro comercial 12 de Octubre". Foto: SOKEN, D., março de 2013.

Cabe destacar a delimitação do uso do território para a realização da atividade de serviço de transporte de pessoas. Do lado boliviano o serviço diário de curta distância entre localidades de Puerto Quijarro e Puerto Suarez é realizado pela Associação de taxistas bolivianos, mão de obra predominantemente masculina ${ }^{96}$. E quanto ao transporte

\footnotetext{
${ }^{96}$ É importante dizer que o transporte de passageiros e de cargas realizado entre as cidades-gêmeas de fronteira é executado predominantemente por taxistas bolivianos. O tipo de veículo utilizado é de passeio, produto de descarte dos países asiáticos que entra na Bolívia pelo porto chileno. Quando esse veículo chega na fronteira brasileira é sobrevalorizado com adicional de serviço de alteração de mão inglesa, cujo preço negociado pode atingir até dez mil dólares. Como sugestão de novas investigações sobre o transporte na Bolívia vale ressaltar que tal atividade acontece em pequena escala e articulada aos deslocamentos do comércio das famílias bolivianas.
} 
de longas distâncias existem várias empresas brasileiras e prestadores de serviços formais e informais que são contratados diretamente pelas "sacoleiras" e se deslocam até a linha da fronteira com destino a Arroyo Concepción ("Feirinha da Bolívia") pelo menos uma vez na semana.

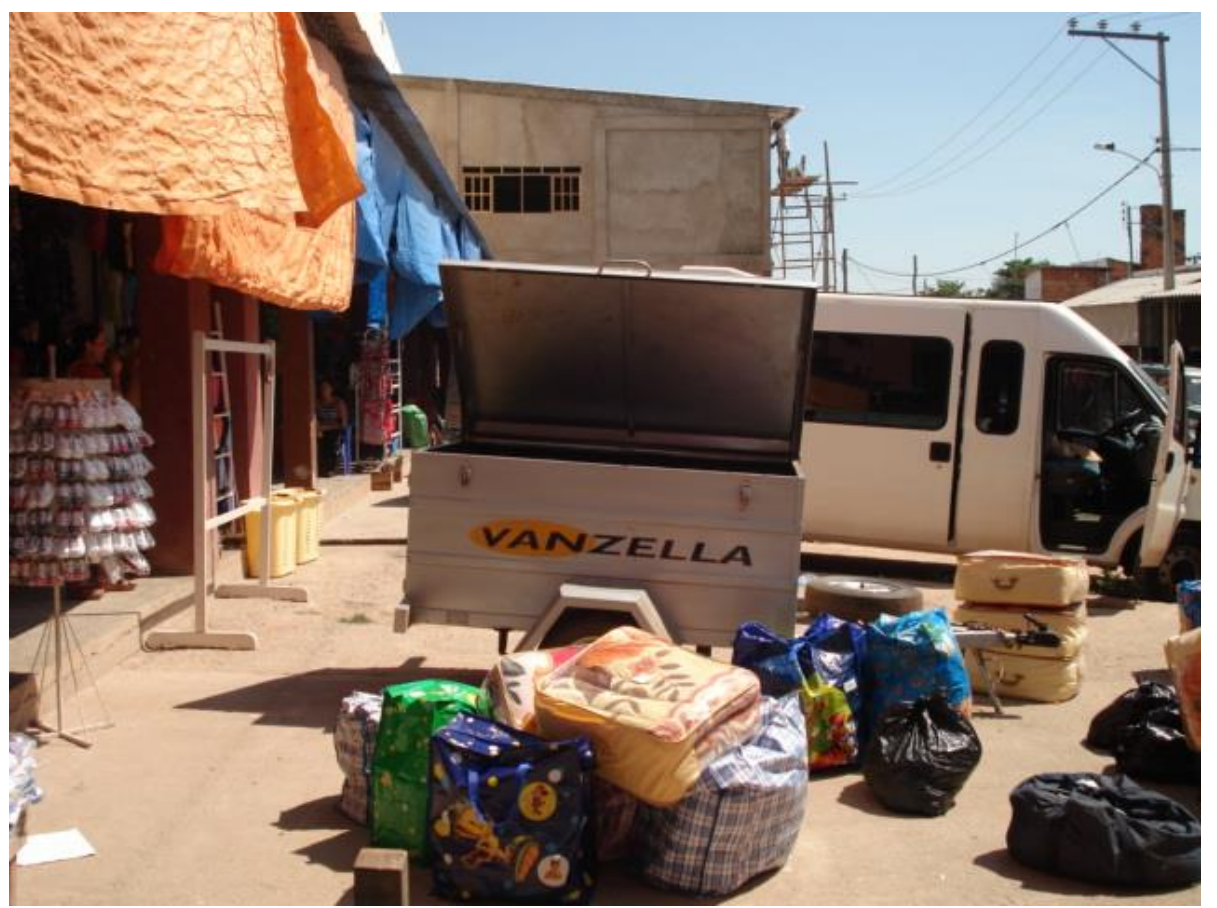

FOTO 16 - Bolívia, Puerto Quijarro, estacionamento de vans brasileiras no "Centro comercial 12 de Octubre".

Foto: SOKEN, D., agosto de 2008.

O transporte de vans soma-se ao comércio "formiguinha ${ }^{97 "}$ na fronteira pois atende distintos grupos, familiares, sacoleiras e turistas e, além disso, amplia o raio de distribuição do comércio popular da fronteira para municípios da região sudoeste do Estado de Mato Grosso do Sul, como Jardim, Guia Lopes da Laguna e Bonito. Sobretudo, esse tipo de transporte oferece maior agilidade para as sacoleiras que trabalham nas feiras de bairros de Campo Grande, as quais realizam várias viagens para a fronteira ao longo da semana e precisam de poucas horas de compras, uma vez que as encomendas já são realizadas na semana anterior.

\footnotetext{
${ }^{97}$ Comércio realizado em pequenas quantidades, é comum nessa área de fronteira o deslocamento diário de pessoas que buscam produtos baratos para revender do outro lado da linha de fronteira.
} 


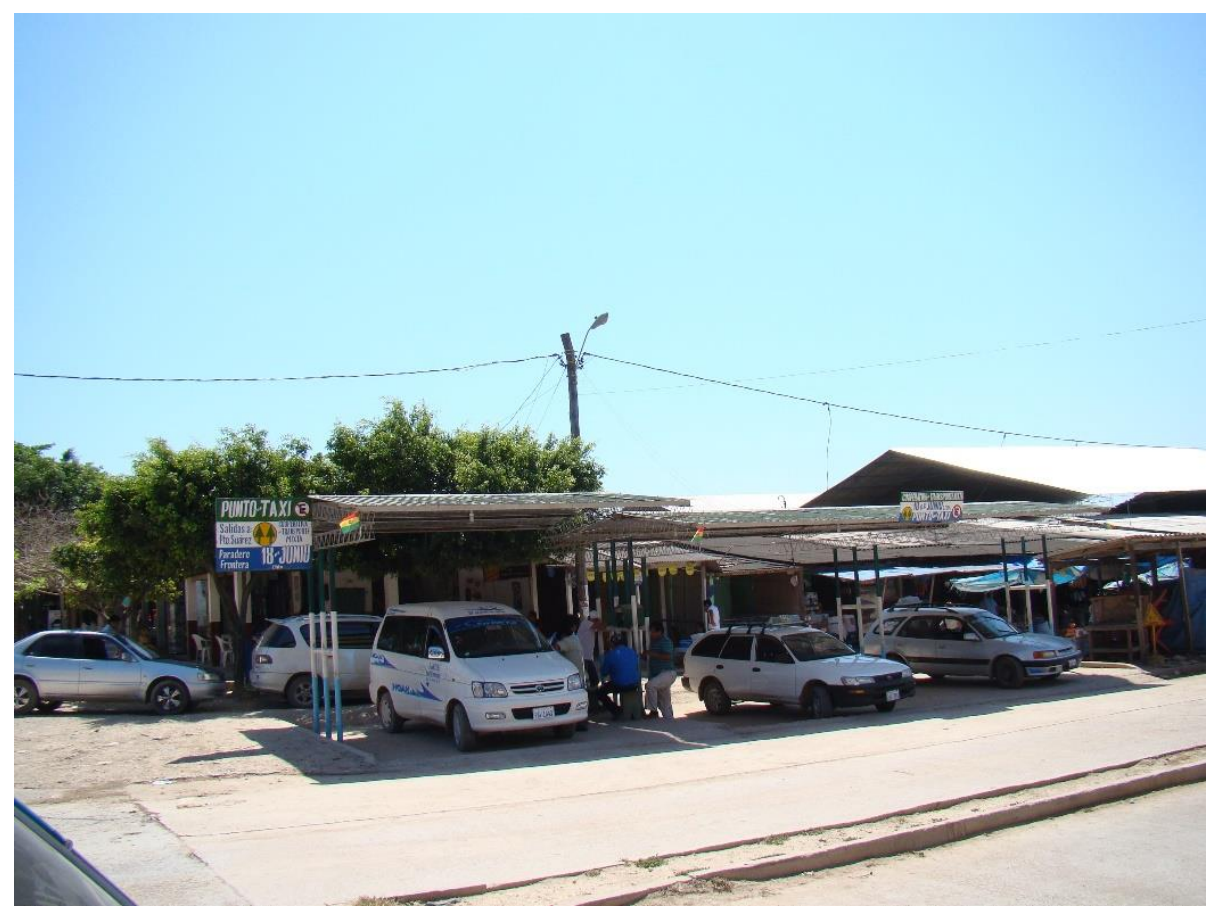

FOTO 17 - Bolívia, Puerto Quijarro, estacionamento de táxis. Foto: SOKEN, D., agosto de 2014.

Alguns prestadores de serviços de transporte de pessoas optam em trabalhar com grupos pequenos, como é o caso da família da FOTO 18 que financiou uma van para atender especificamente grupos de "sacoleiras" que realizam compras em cidades de fronteira. Mas, a maioria das "sacoleiras" que se desloca para a fronteira utiliza ônibus fretado, porque os preços das passagens são mais adequados às necessidades desse grupo. Segundo a prestadora de serviços de transporte de pessoas, ao longo de cinco anos de trabalho nunca teve mercadorias apreendidas, ao contrário dos fretados que estão mais propensos às apreensões e fiscalizações por parte da Receita Federal, uma vez que o número de passageiros e o volume de mercadoria transportada é bem maior. 


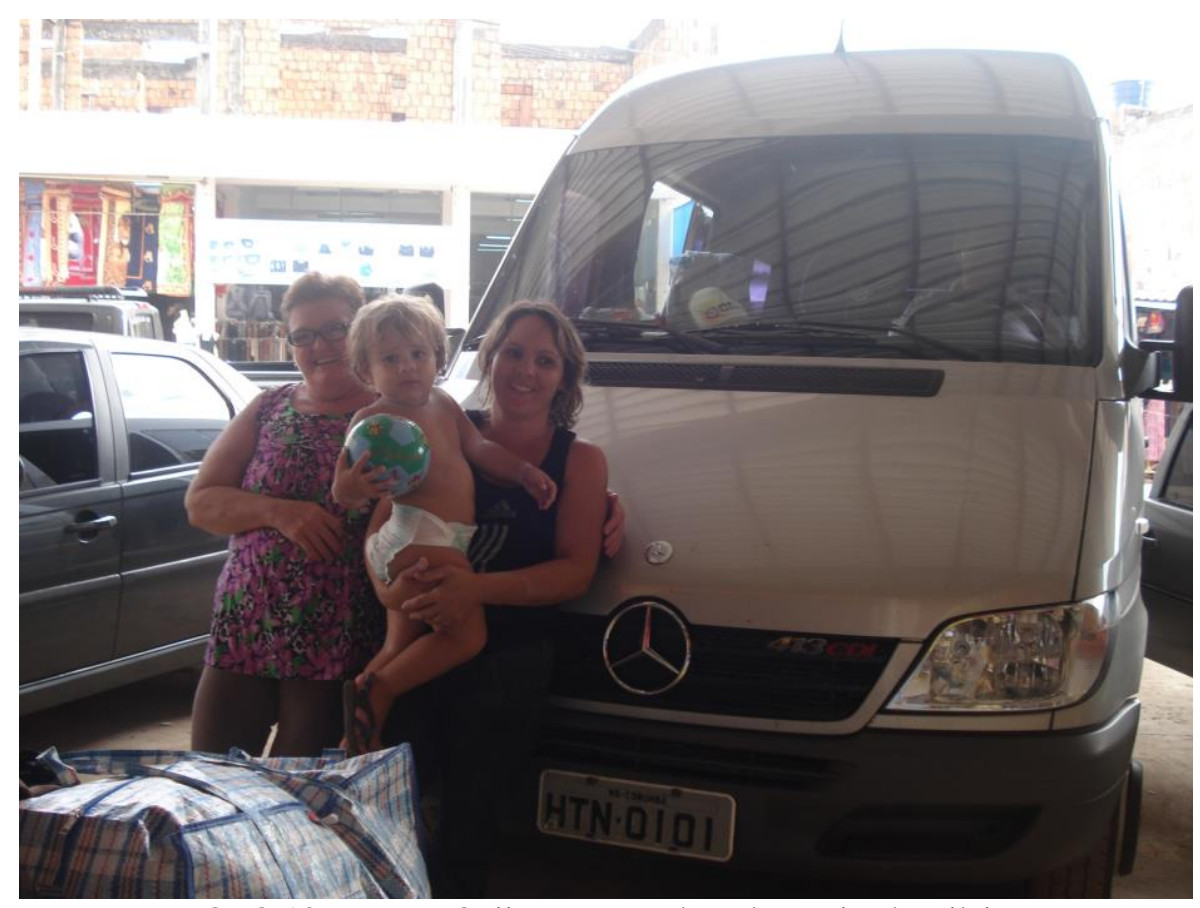

FOTO 18 - Puerto Quijarro, prestadora de serviço brasileira.

Foto: SOKEN, D., março de 2013.

A Avenida Bolívar, a mais importante via de circulação da cidade de Puerto Suarez, fica aproximadamente a $14 \mathrm{~km}$ de distância da fronteira entre Brasil e Bolívia. Nas décadas de 1980 e 1990 era a única localidade que oferecia produtos importados especialmente cosméticos, eletrônicos e artigos de pesca, entre outros produtos do turismo de compras na faixa de fronteira. Atualmente, concentra atividades de serviços de escritórios, serviços públicos, hotel, restaurantes, supermercado e recentemente as calçadas passaram a ser ocupadas por mulheres comerciantes que abastecem a cidade com produtos populares de vários gêneros, alimentício, vestuário e eletrônicos no geral. 


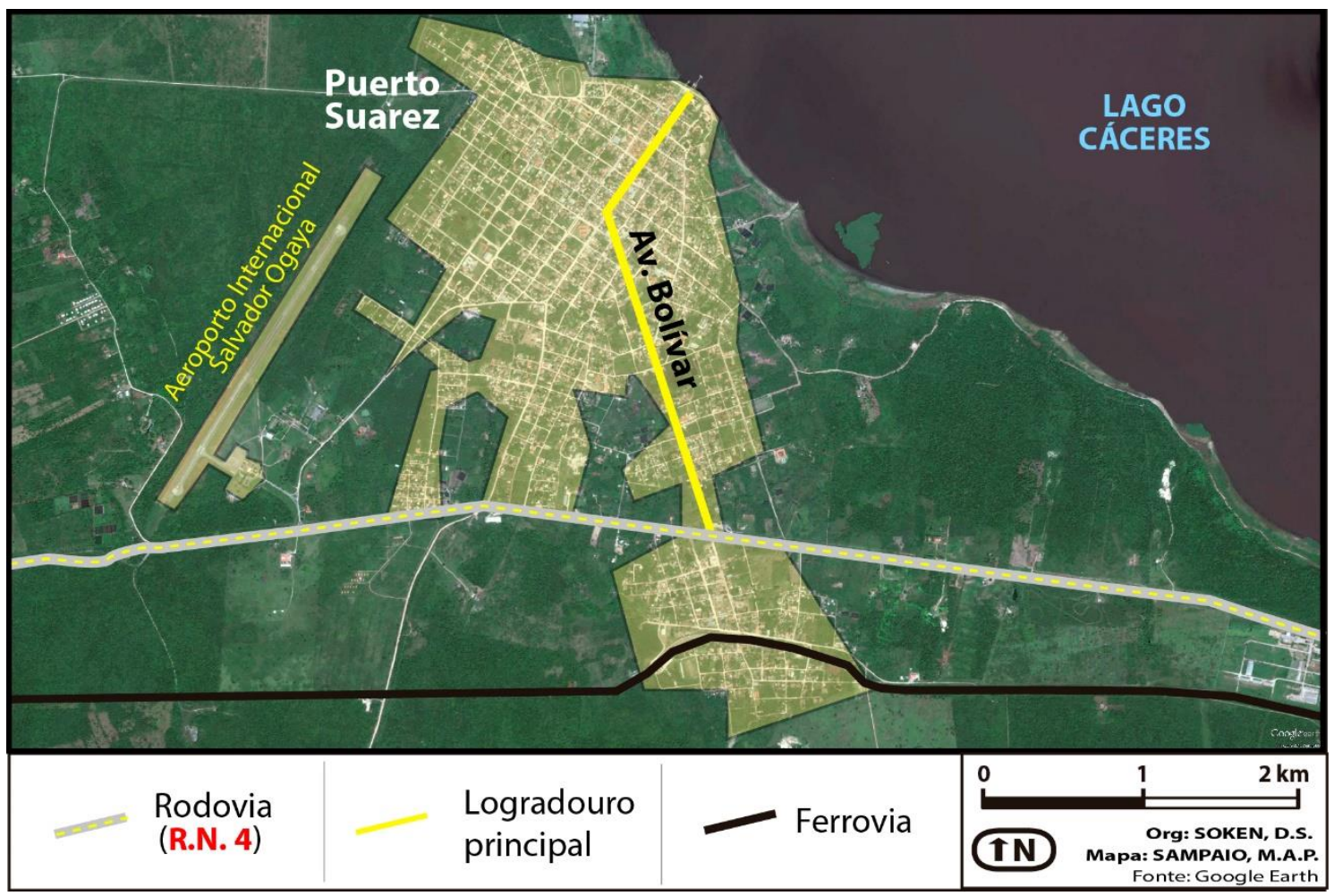

FIGURA 7 - Bolívia, Puerto Suarez, imagem de satélite da avenida Bolívar com acesso pela rodovia boliviana "Ruta Nacional 4".

Organização: SOKEN, D.S.

Elaboração: SAMPAIO, M.A.P.

Fonte: Google maps, 2015

A imagem a seguir revela as fachadas das casas comerciais que abasteciam nas décadas de 1980 e 1990 a faixa de fronteira com produtos importados. Atualmente nesses estabelecimentos ainda estão à venda produtos do período do auge do comércio de fronteira, mas no geral vendem produtos de artesanato e realizam pequenos serviços de escritório, como reprodução de documentos e serviços contábeis para a população local. 


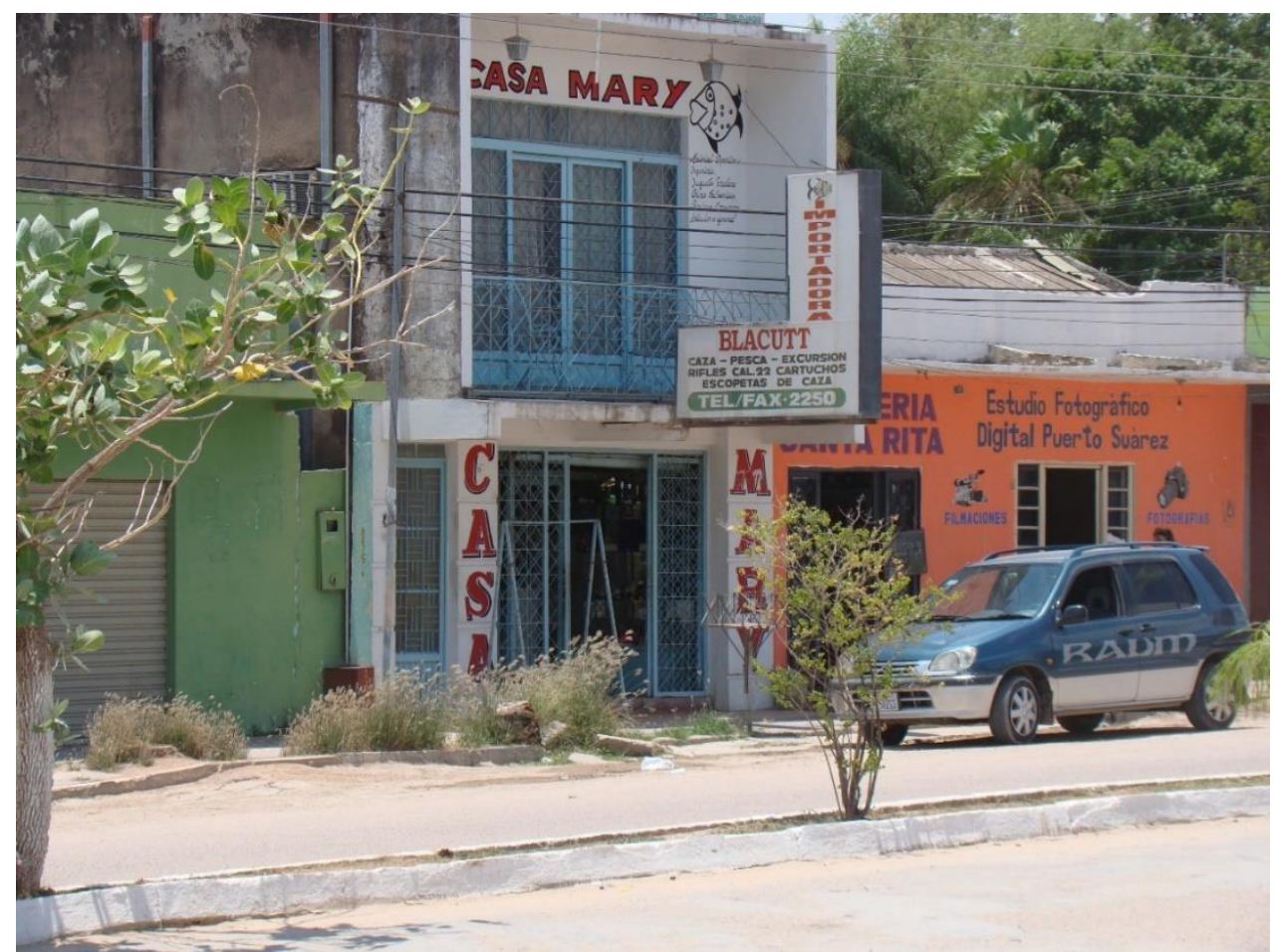

FOTO 19 - Bolívia, Puerto Suarez, avenida Bolívar, fachada de estabelecimentos comerciais da década de 1980 a 1990 da faixa de fronteira.

Foto: SOKEN, D., agosto de 2008

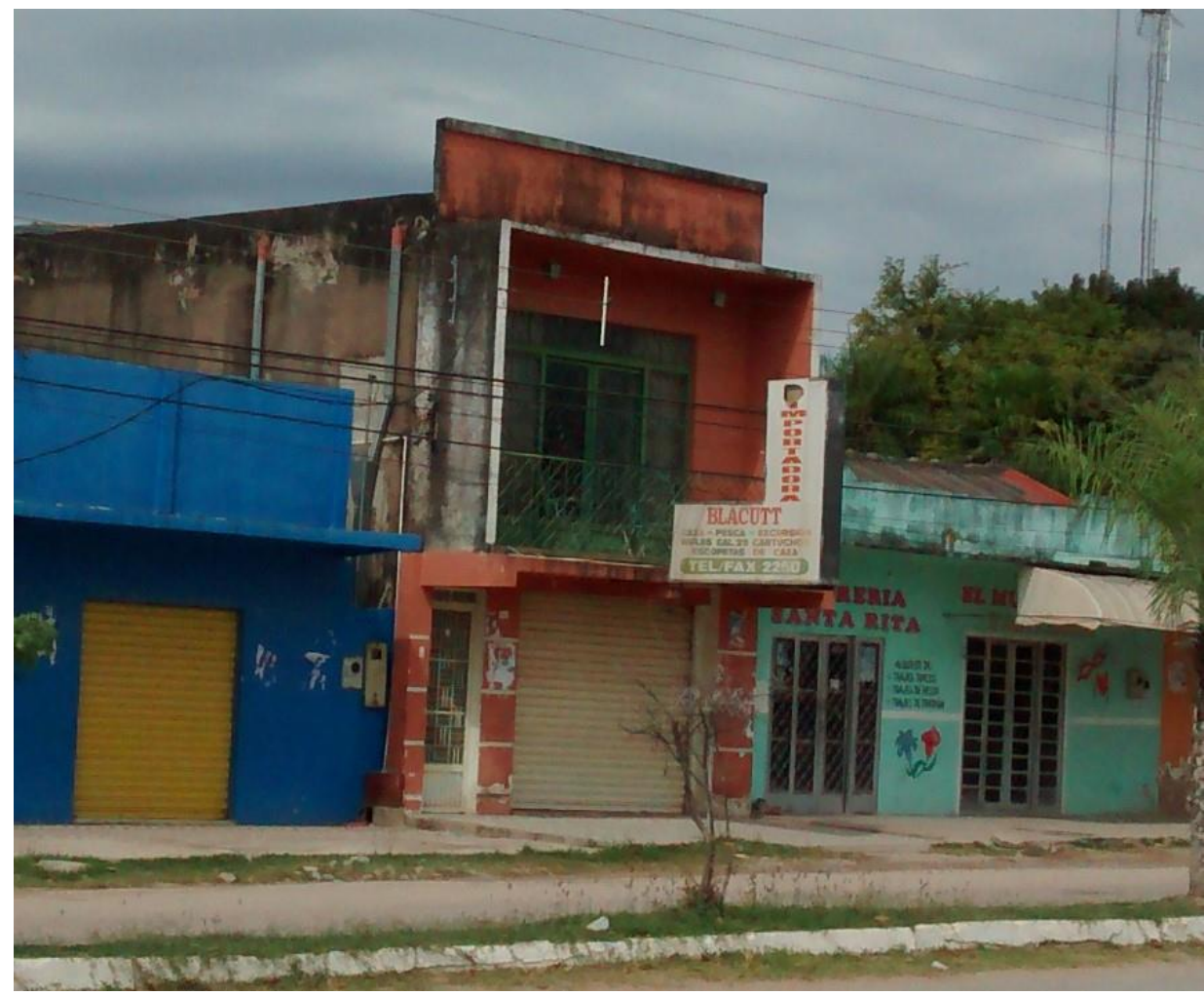

FOTO 20 - Bolívia, Puerto Suarez, avenida Bolívar, fachada de estabelecimentos comerciais da década de 1980 a 1990 da faixa de fronteira.

Foto: SOKEN, D., setembro de 2014 
Observa-se que os estabelecimentos comerciais de produtos populares de Puerto Suarez estão em condições precárias, construções inacabadas providas apenas pela rede elétrica e existência de esgoto a céu aberto nas ruas ao entorno do Mercado Municipal "Nuestra Señora El Carmem" próximo à Avenida Bolívar. No geral, são pequenos comércios organizados por mulheres que oferecem uma diversidade de produtos provenientes de várias localidades da Bolívia. E que tem como principal característica a estrutura informal nas relações de trabalho feminino, cuja maioria obtém remuneração indefinida e/ou irregular.

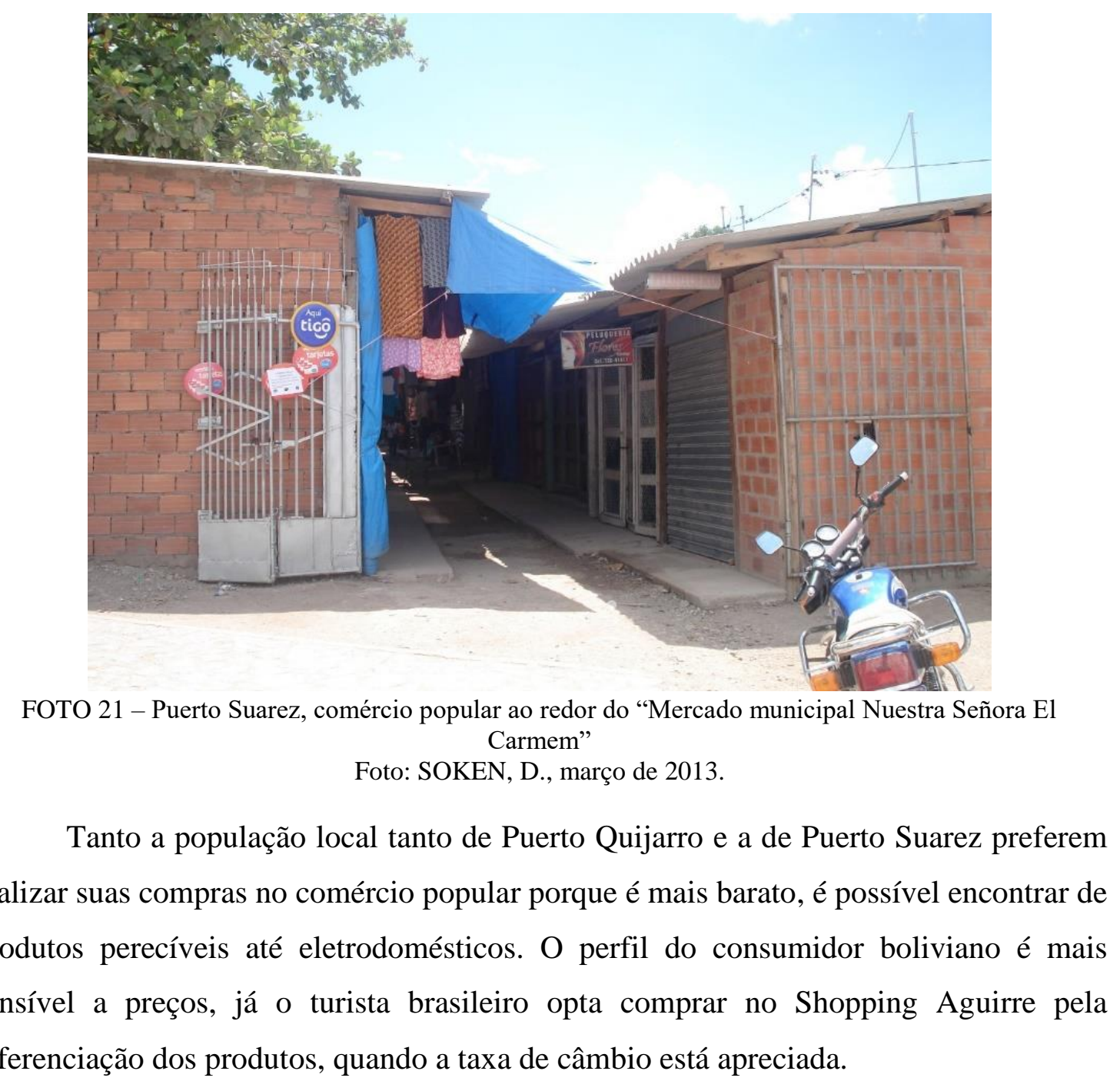




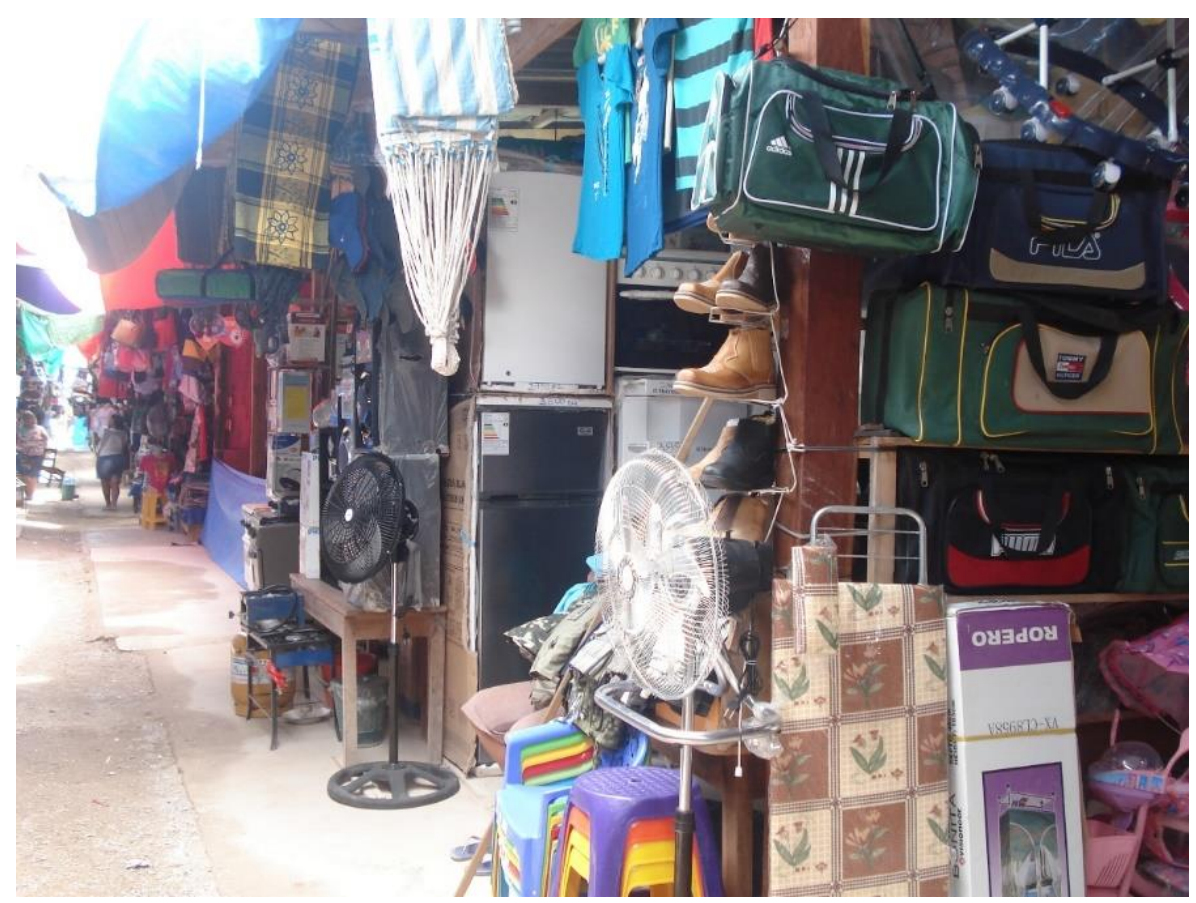

FOTO 22 - Bolívia, Puerto Suarez, comércio popular ao redor do "Mercado municipal Nuestra Señora El Carmem".

Foto: SOKEN, D., março de 2013.

Em Corumbá, foram eleitas as seguintes localidades de pesquisa: o centro comercial $^{98}$ onde se concentram as atividades de comércio e serviço da cidade, delimitado pelo quadrilátero das ruas Treze de Junho, Frei Mariano, Delamare e Quinze de Novembro; a Feira Brasil-Bolívia (Brasbol) ${ }^{99}$ localizada no bairro Dom Bosco; o comércio e serviços das ruas Dom Bosco, Edu Lobo e América e avenida Porto Carreiro.

\footnotetext{
${ }^{98}$ Segundo registro da Associação Comercial de Corumbá o total de comerciantes associados soma 140, sendo $23 \%$ constituídos por mulheres, conforme dados coletados no mês de novembro de 2009 .

${ }^{99}$ No momento da pesquisa a Feira Brasbol estava localizada na rua Edu Lobo, ou como é conhecida pela população local atrás do cemitério da cidade. No entanto, uma nota da prefeitura divulgada pela imprensa local em maio de 2013 a feira Brasbol foi interditada.
} 


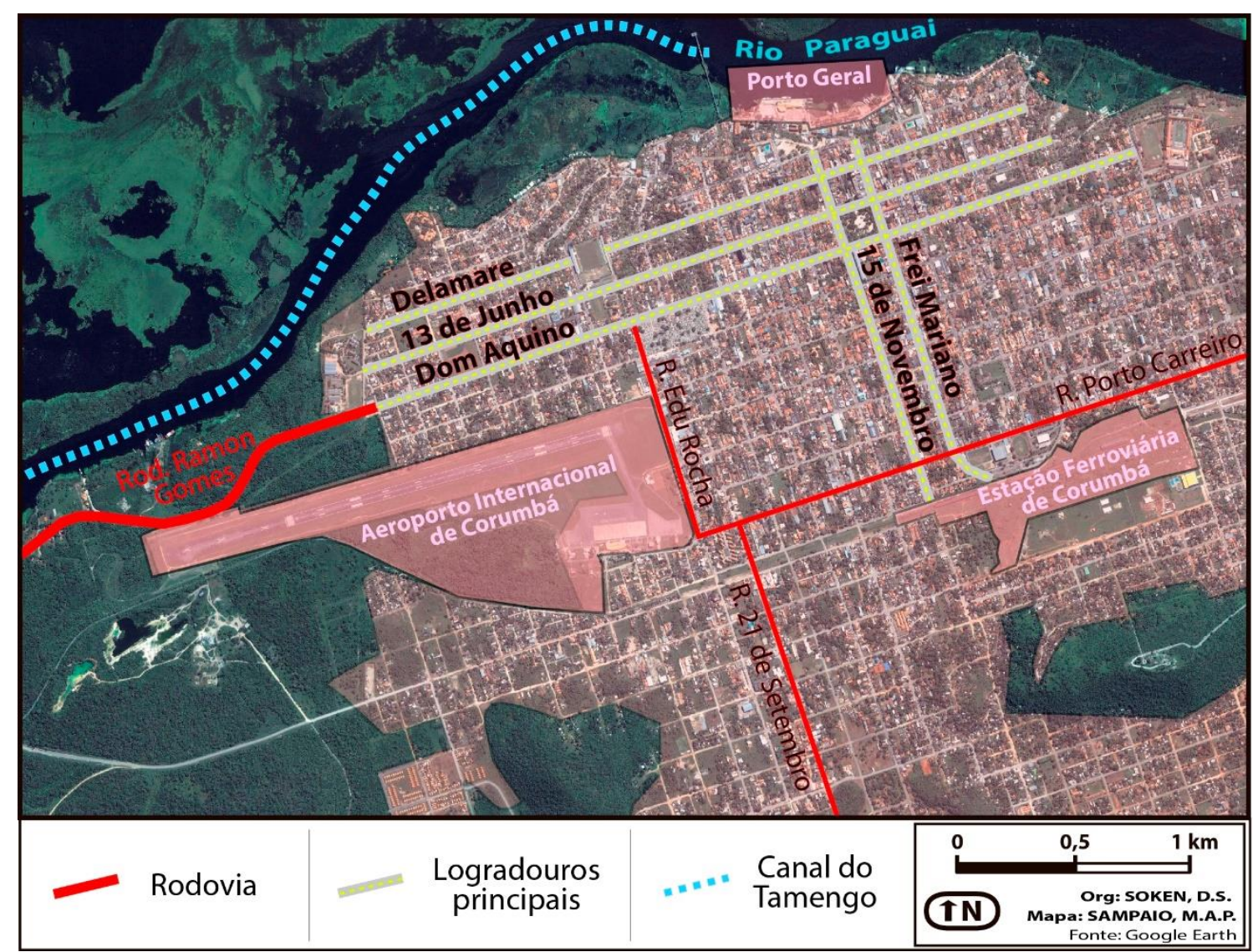

FIGURA 8 - Brasil, Corumbá, imagem de satélite da rua Dom Aquino e Treze de Junho e das principais ruas que formam o quadrilátero central constituído pelas ruas Frei Mariano, Delamare, Quinze de Novembro.

Organização: SOKEN, D.S.

Elaboração: SAMPAIO, M.A.P.

Fonte: Google maps, 2015

A formação do comércio da cidade de Corumbá está vinculada à história da migração de palestinos, libaneses e jordanianos para este lado do Brasil (ITO, 1992; OLIVEIRA, 1998). Conforme as observações de Oliveira (1998) os comerciantes palestinos tomaram a frente do processo de retomada da dinâmica do comércio de exportação para as cidades bolivianas. No entanto, a partir da década de 1990 o comércio de exportação da cidade foi sendo realizado por comerciantes de outras regiões, tanto do lado boliviano que inunda a fronteira com produtos importados de vários países quanto do lado brasileiro que recebe produtos diretamente da indústria paulista (OLIVEIRA, 1998).

A relação fronteiriça entre comerciantes palestinos e bolivianos intensificou-se a partir do comércio de exportação de produtos de vestuário e calçados a ponto dos estabelecimentos comerciais mudarem a razão social para exportadoras que de acordo com o relato de Oliveira (1998, p. 71), “a paisagem das ruas centrais (nas portas das 
pequenas lojas) de Corumbá, amontoados de caixas de papelão e sacos sintéticos, abarrotados de sandálias de borracha, tênis, camisetas e roupas íntimas". Segundo Oliveira essa relação tinha a base frágil formada pelo reduzido capital dos palestinos e pelo pequeno comércio dos bolivianos.

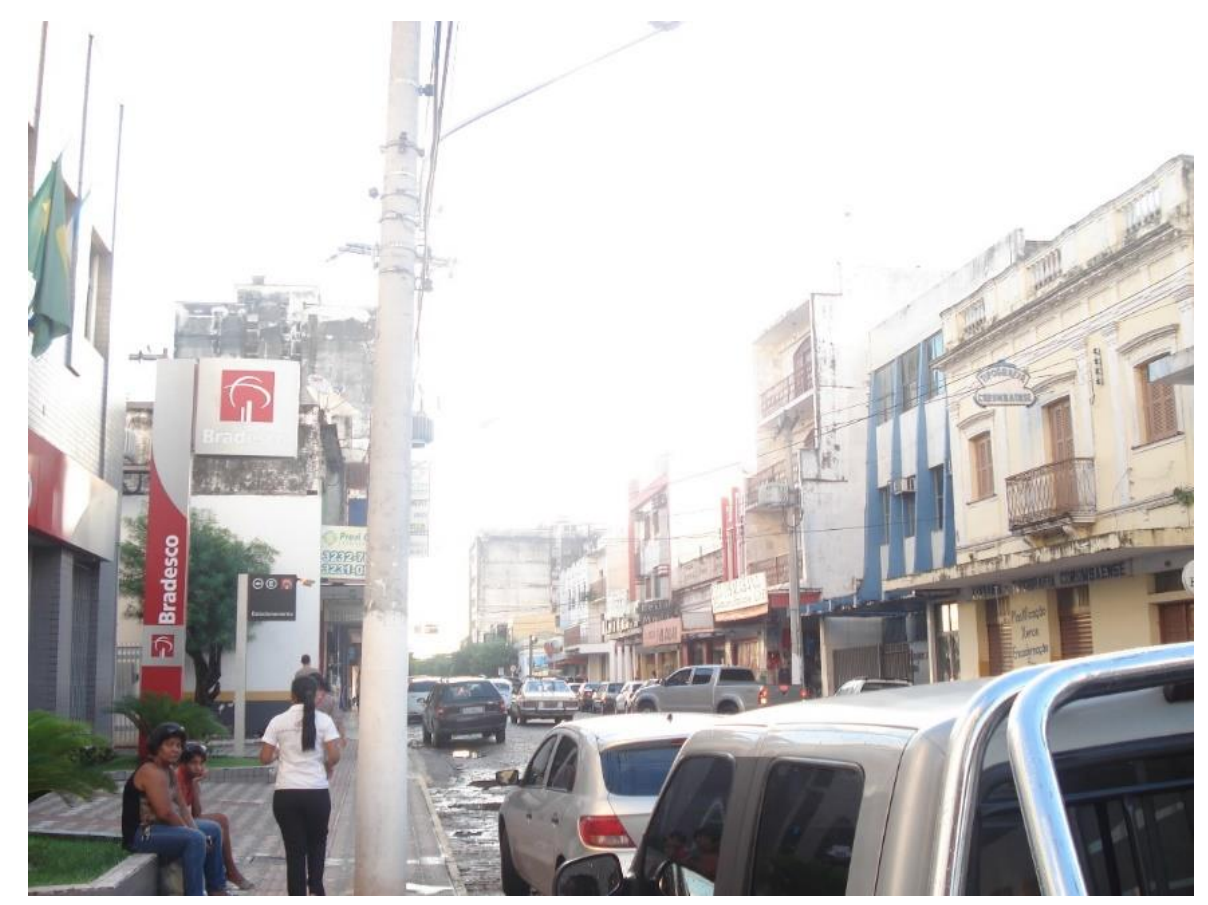

FOTO 23 - Corumbá, rua Delamare, área central Foto: SOKEN, D., março de 2013.

Para além da retomada do comércio de exportação da cidade Corumbá, observouse que a área central da cidade de Corumbá se ampliou com a construção de prédios comerciais dos palestinos com a dupla função de moradia e comércio, bem como as ruas da cidade foram tomadas pelos fluxos de carros com placa boliviana (OLIVEIRA, 1998).

Sobretudo, ressaltou Ito (1992), que a atividade do comércio varejista de Corumbá tem como função além de abastecer a população local e as cidades fronteiriça boliviana, ainda abastece as fazendas do Pantanal. Outro destaque é o comércio atacadista que foi ocupando áreas próximas a estação ferroviária localizada nas ruas Cabral, Joaquim Murtinho e Porto Carrero e também as ruas Dom Aquino e Edu Lobo, com sentido para a fronteira, se especializaram no comércio de exportação e importação (ITO, 1992). 


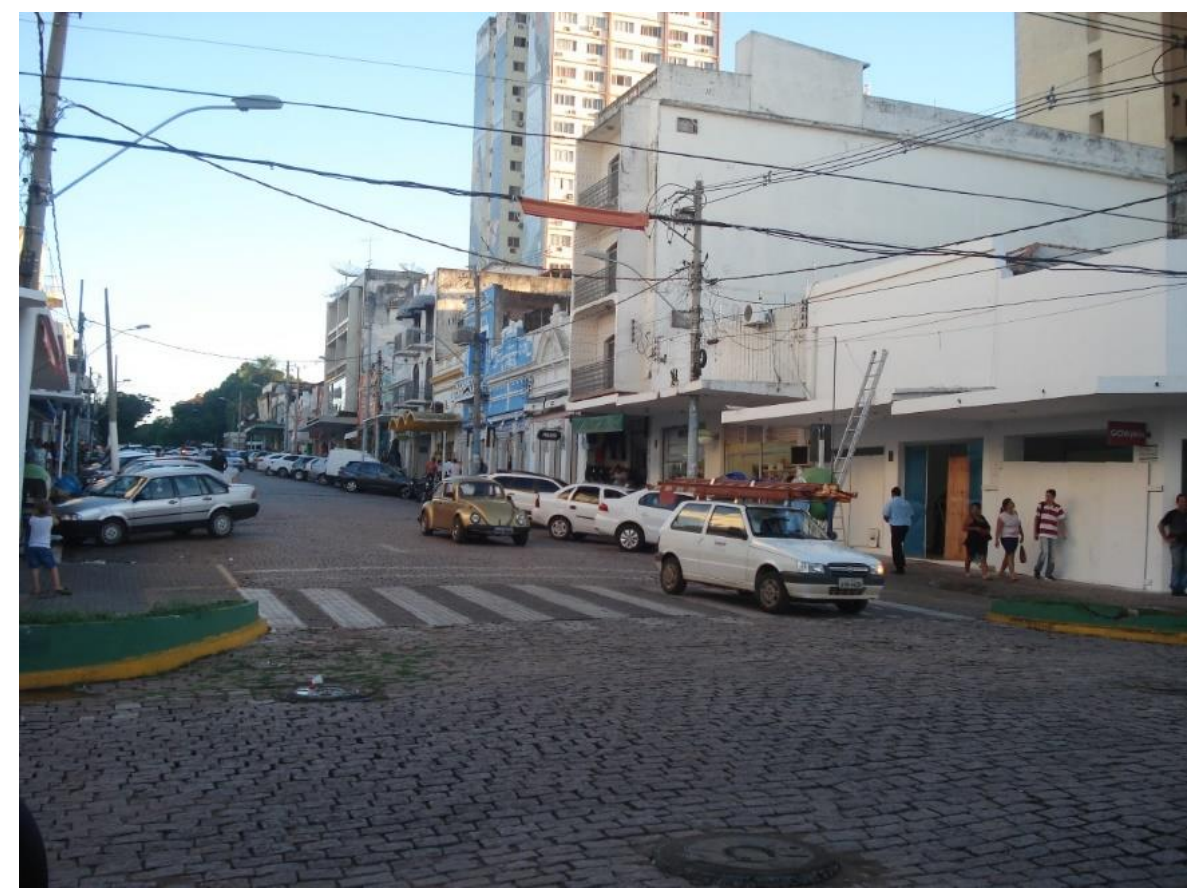

FOTO 24 - Corumbá, rua Frei Mariano na área central Foto: SOKEN, D., março de 2013.

Com o crescimento do comércio de exportação e importação de produtos provenientes de várias fronteiras da Bolívia e do mercado paulista possibilitou aos pequenos comerciantes bolivianos instalados na cidades-gêmeas da fronteira estender o comércio no lado brasileiro. Passaram a ocupar os espaços das ruas como ambulantes, nas feiras de bairro e se fixaram na cidade de Corumbá com a comércio de produtos diversos a partir da criação da feira Brasbol. 


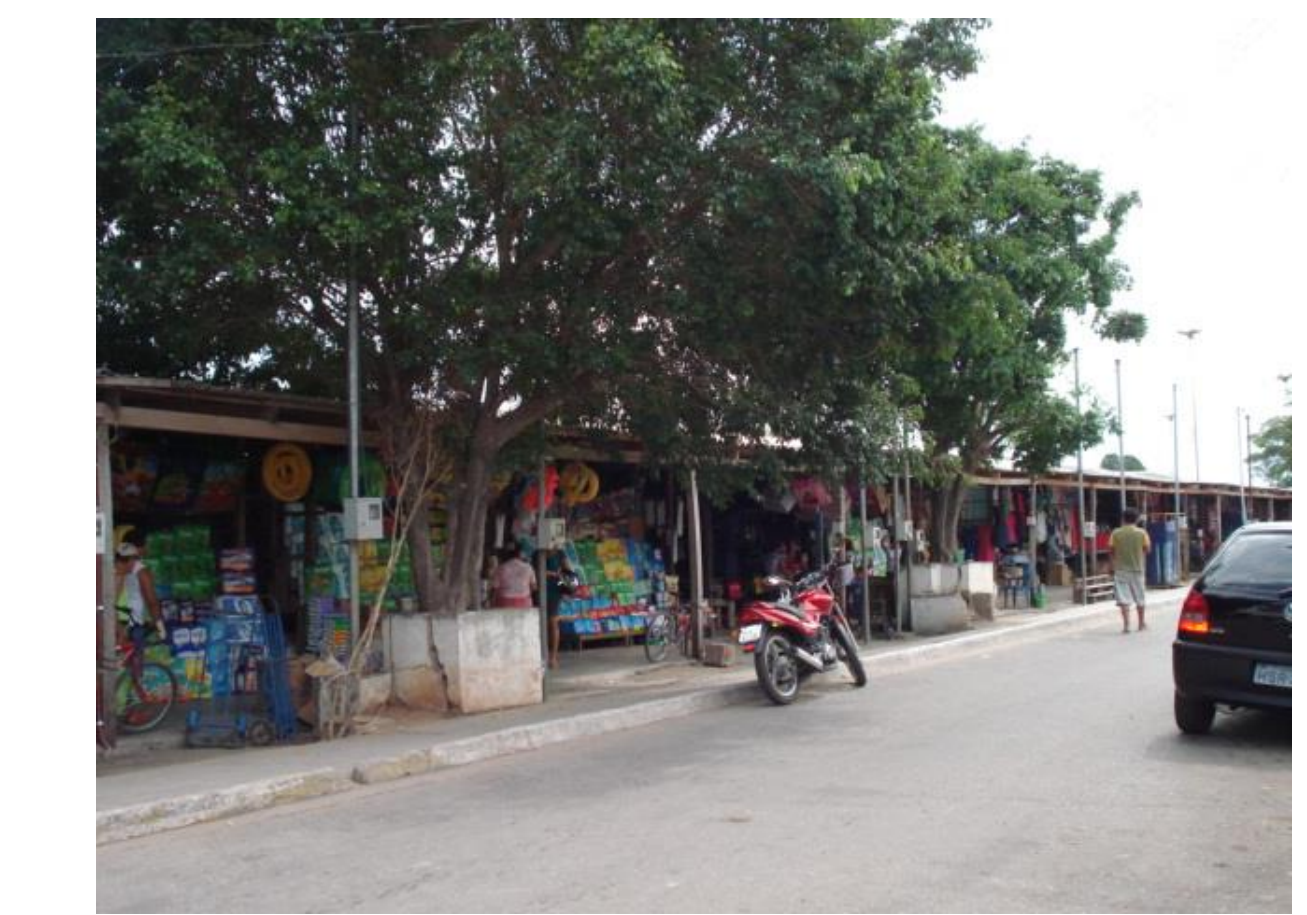

FOTO 25 - Corumbá, área externa da Feira Brasil-Bolívia (Brasbol), extinta em maio de 2013. Foto: SOKEN, D., março de 2013.

A Feira Brasil e Bolívia -"Brasbol” constituía numa associação de comerciantes criada na década de 1990, que abrigava cerca de 136 comerciantes varejistas de produtos populares diversos. Verificou-se durante a pesquisa de campo, realizada no mês de março do ano de 2013, a existência de estrutura organizacional "enxuta e flexível”, constituída por mulheres proprietárias e/ou funcionárias que declararam certa irregularidade dos soldos do trabalho realizado, em dias de baixo movimento era comum o não pagamento de salários para algumas funcionárias. Situação que se explica pelo fato de as relações trabalhistas se misturarem com as relações familiares, uma vez que a grande maioria das funcionárias desses locais era formada por cônjuges ou por filhas e sobrinhas.

A presença de mulheres bolivianas vendendo produtos de artesanato boliviano é muito significativa nas ruas do centro de Corumbá. Fazem uso do espaço da atividade do turismo, estão em locais de fluxo populacional como hotéis, restaurantes e praças. 


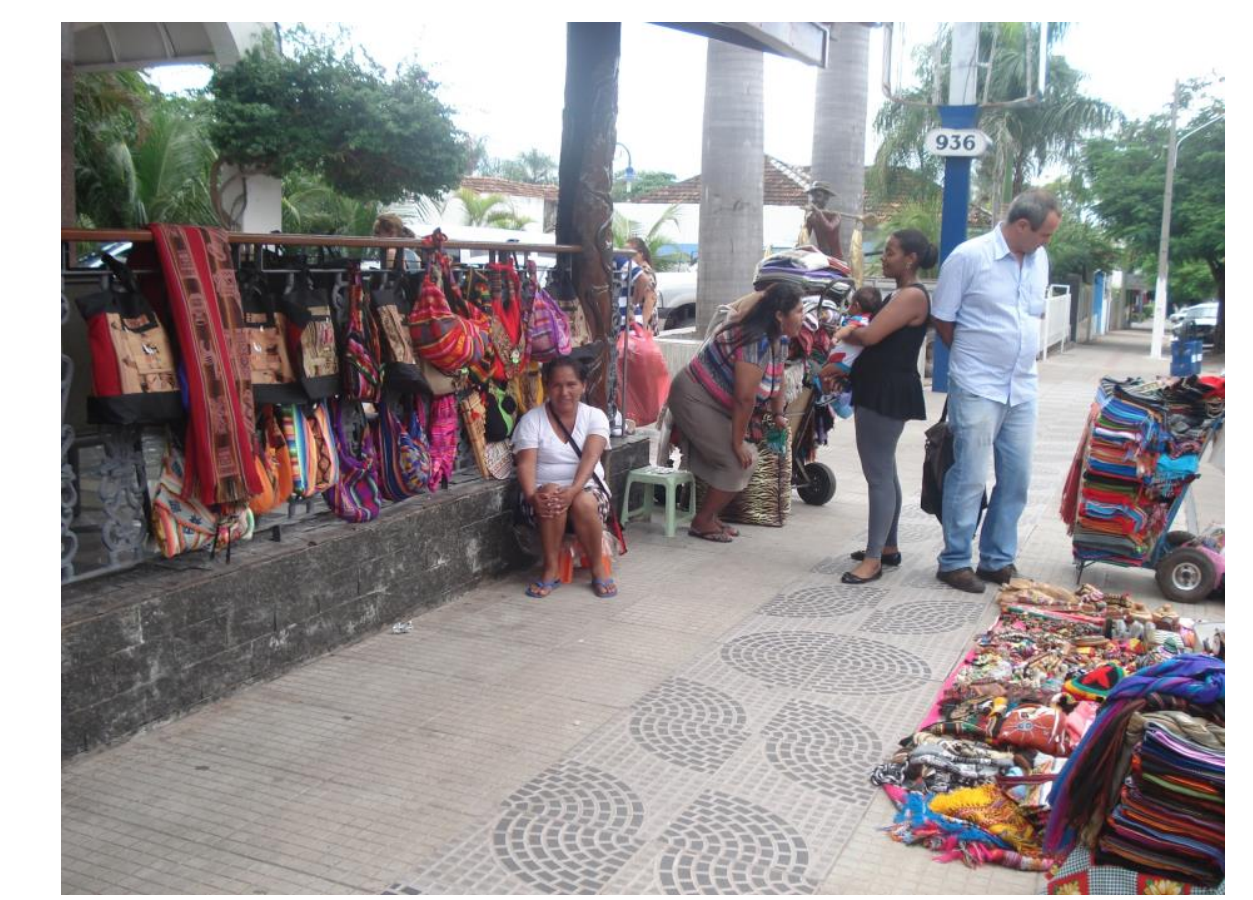

FOTO 26 - Corumbá, vendedora ambulante de artesanato na rua Dom Aquino, área central Foto: SOKEN, D., março de 2013.

Com a extinção da Feira Brasbol ${ }^{100}$ o espaço das ruas é dividido com outras mulheres que tiveram seu local de trabalho interditado pelo poder executivo local. Recentemente a forte presença dessas ex-comerciantes da Brasbol nas feiras livres da cidade de Corumbá que tem causado conflitos entre feirantes e prefeitura.

Outras buscaram formas alternativas para realizar suas atividades comerciais em Corumbá, tais como, alugaram garagens, corredores de prédios, prédios com instalações precárias. Já as demais ex-comerciantes da Brasbol encontraram oportunidades de se instalar nas proximidades do Centro Comercial 12 de Octubre em Puerto Quijarro.

No geral, foram encontradas, em Corumbá, 10 mulheres proprietárias de seu negócio, destas, 02 têm jornada de trabalho que varia entre 7 e 8 horas diárias; 05 trabalham de 9 e 12 horas diárias e 03 permanecem no trabalho até 18 horas por dia. Em

\footnotetext{
${ }^{100}$ O documento de interdição da Feira Brasbol de maio de 2013 teve origem a partir do grupo de trabalho criado em abril de 2013 pela Secretaria Municipal de Infraestrutura, Habitação e Serviços Públicos de Corumbá para tratar do reordenamento do espaço público onde estava instalada a Feira. Dentre as questões apontadas para a interdição da feira constaram o laudo do Corpo de Bombeiros, da Vigilância Sanitária e da Receita Federal, onde o Ministério Público com base nesse conjunto de documentos acionou o poder local para tomar providências quanto à regularização do espaço público. Conforme constou na matéria jornalística, o Ministério Público começou a investigação sobre a Feira Brasbol no ano de 2011 com base em denúncia de desvio de finalidade. Segundo o documento a Feira Brasbol teve como origem a venda de produtos de artesanato e tornou-se uma feira de comércio popular (GAERTNER, 2013; NUNES, 2013).
} 
contrapartida, o total de funcionária somou 81 mulheres, sendo 04 contratadas com a jornada de trabalho de menos de 6 horas; 62 com jornadas de 7 e 8 horas diárias e 15 trabalham entre 9 e 12 horas, diariamente.

Observa-se que em Puerto Quijarro e Puerto Suarez cerca de 34 mulheres são proprietárias de estabelecimentos comerciais. A maioria trabalha entre 9 e 12 horas diariamente. Já das 28 funcionárias localizadas, apenas 02 trabalham menos de 6 horas diárias; 16 realizam a jornada de trabalho de 7 a 8 horas; 08 trabalham entre 9 e 12 por dia e 02 trabalham até 18 horas, diariamente.

\begin{tabular}{|c|c|c|c|c|c|c|c|}
\hline \multirow[b]{3}{*}{ Jornada de trabalho } & \multicolumn{6}{|c|}{ Lugar da pesquisa } & \multirow[b]{3}{*}{ Total } \\
\hline & \multicolumn{2}{|c|}{ Corumbá } & \multicolumn{2}{|c|}{ Puerto Quijarro } & \multicolumn{2}{|c|}{ Puerto Suarez } & \\
\hline & 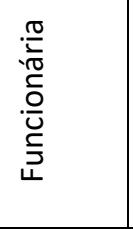 & 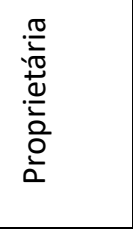 & 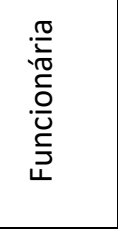 & 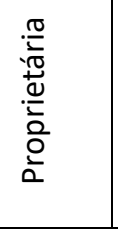 & 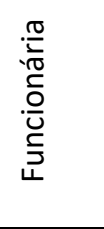 & 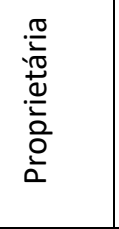 & \\
\hline$<=6$ horas & 4 & 0 & 1 & 2 & 1 & 0 & 8 \\
\hline 7 a 8 horas & 62 & 2 & 13 & 2 & 3 & 0 & 82 \\
\hline 9 a 12 horas & 15 & 5 & 8 & 21 & 0 & 2 & 51 \\
\hline 13 a 18 horas & 0 & 3 & 1 & 5 & 1 & 2 & 12 \\
\hline Total & 81 & 10 & 23 & 30 & 5 & 4 & 153 \\
\hline
\end{tabular}

TABELA 15 - Total de mulheres segundo jornada de trabalho por condição de trabalho distribuída em Corumbá, Puerto Quijarro e Puerto Suarez, período de abrangência corresponde a 15 a 23 de março de 2013.

Fonte: Questionário 04 (Perfil socioeconômico)

Elaboração: SOKEN, D., março de 2013.

A estrutura organizacional dos estabelecimentos da área central e demais localidades em Corumbá, com exceção da Feira Brasbol, mantém contratos de trabalho formal, tanto as mulheres proprietárias de estabelecimentos quanto as funcionárias recebem rendimento regulares, além disso, têm suas atribuições bem definidas por meio de uma hierarquia funcional e profissional.

Com base nos dados da pesquisa, no que se refere às atribuições de cargos, constatou-se em Corumbá a existência de maior hierarquia funcional cerca de $56 \%$ das mulheres atuam em funções diferenciadas, com destaque para as seguintes: gerente administrativo, consultora dermatológica, consultora de moda, analista de qualidade (ISO), gestão de recursos humanos, educadora coorporativa, gerente de atenção à saúde, maquiadora e designer de sobrancelhas, gerente de suprimentos, compradora, agente de crediário. Além daquelas funções tradicionais, quais sejam: recepcionista, auxiliar 
administrativo, camareira, lavadeira, auxiliar de cozinha, auxiliar de enfermagem, secretária, auxiliar de tesouraria, monitoria de sala, coordenadora pedagógica, bibliotecária, professora, supervisora, entre outras.

Por sua vez, a estrutura organizacional dos estabelecimentos do lado boliviano apresentou-se bem restrito. A hierarquia é definida entre proprietárias e vendedoras/atendentes, cerca de $44 \%$ das mulheres que trabalham em Puerto Quijarro e Puerto Suarez são donas do próprio negócio e 35\% são vendedoras ou atendentes; apenas $3 \%$ são gerentes e $5 \%$ são caixas e outras funções que abrange $13 \%$ são gerente de setor, auxiliar contábil, cobrança em domicílio, cozinheira e faxineira, auxiliar de departamento pessoal, operadora de crédito, secretária, entre outras.

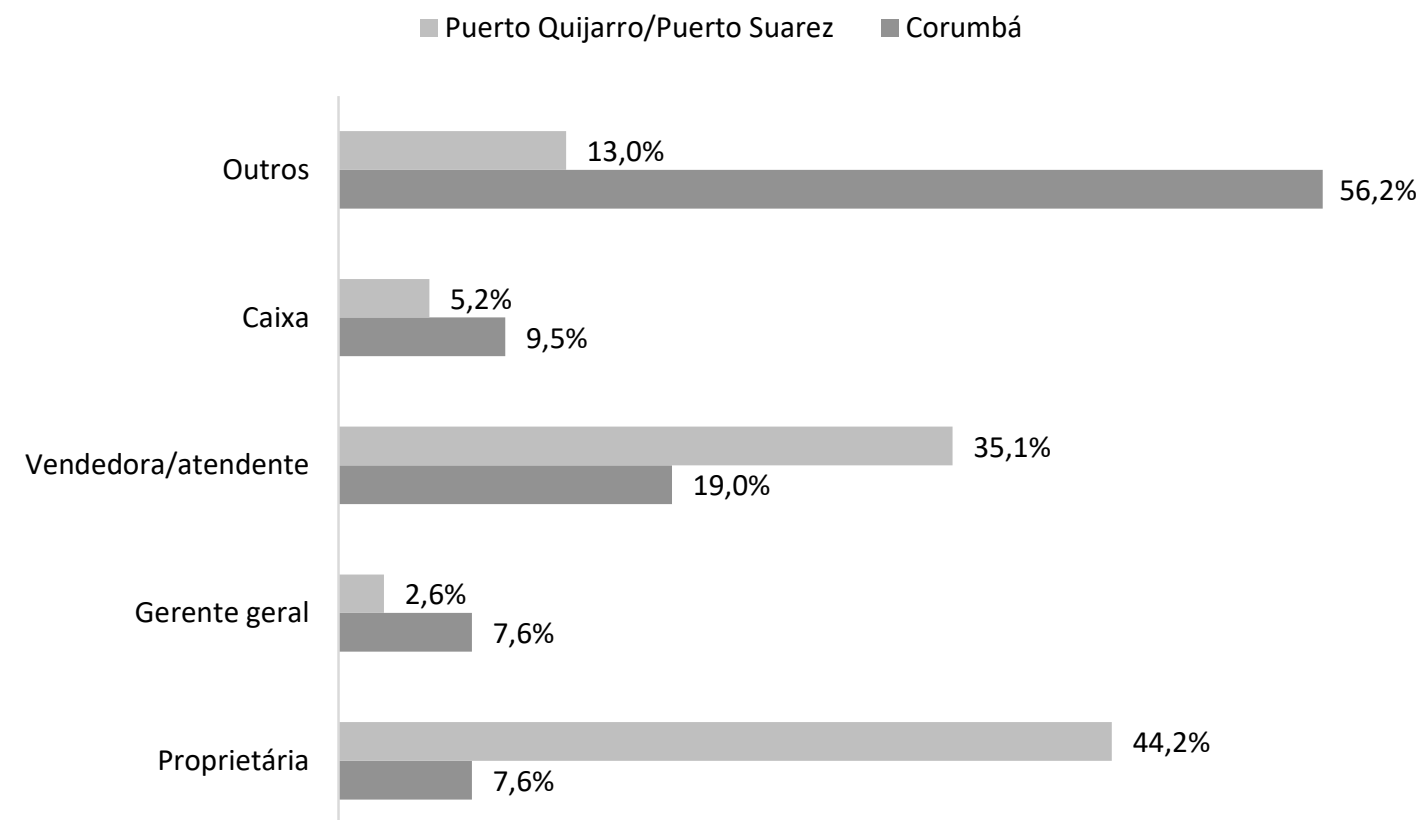

GRÁFICO 30 - Porcentagem de mulheres segundo a hierarquia funcional dos estabelecimentos distribuída em Corumbá, Puerto Quijarro e Puerto Suarez, referente ao período de 15 a 23 de março de 2013.

Fonte: Questionário 04 (Perfil socioeconômico)

Elaboração: SOKEN, D., março de 2013.

Com relação a faixa etária das mulheres, do total de 153 pesquisadas, cabem os seguintes destaques: cerca de 55 mulheres estão na faixa etária de 20 a 29 anos; outras 52 mulheres estão entre 30 e 39 anos; 25 mulheres têm entre 40 e 49 anos; 10 estão acima de 50 anos; e foram encontradas 11 trabalhadoras que estão entre 10 e 19 anos.

Ao relacionar a faixa etária e ao nível de empregabilidade do lugar da pesquisa, observa-se que mulheres mais jovens estão em Corumbá. Existem 34 mulheres 
distribuídas entre a faixa etária de 20 a 29 anos e um total de 33 mulheres entre a faixa etária de 30 a 39 anos. Foi encontrado no comércio popular a presença de uma vendedora de 12 anos que trabalhava no período da tarde e ajudava os pais com as vendas de eletrônicos ${ }^{101}$.

Já no lado boliviano, a pesquisa revelou maior presença de mulheres com idade acima de 30 anos. Somando as duas cidades bolivianas foram encontradas 19 trabalhadoras distribuídas entre a faixa etária de 30 a 39, o mesmo número foi encontrado entre a faixa etária de 40 a 59 anos, e 03 mulheres declararam ter mais de 60 anos de idade. E entre a faixa etária de 15 a 29 anos foram encontradas 27 mulheres.

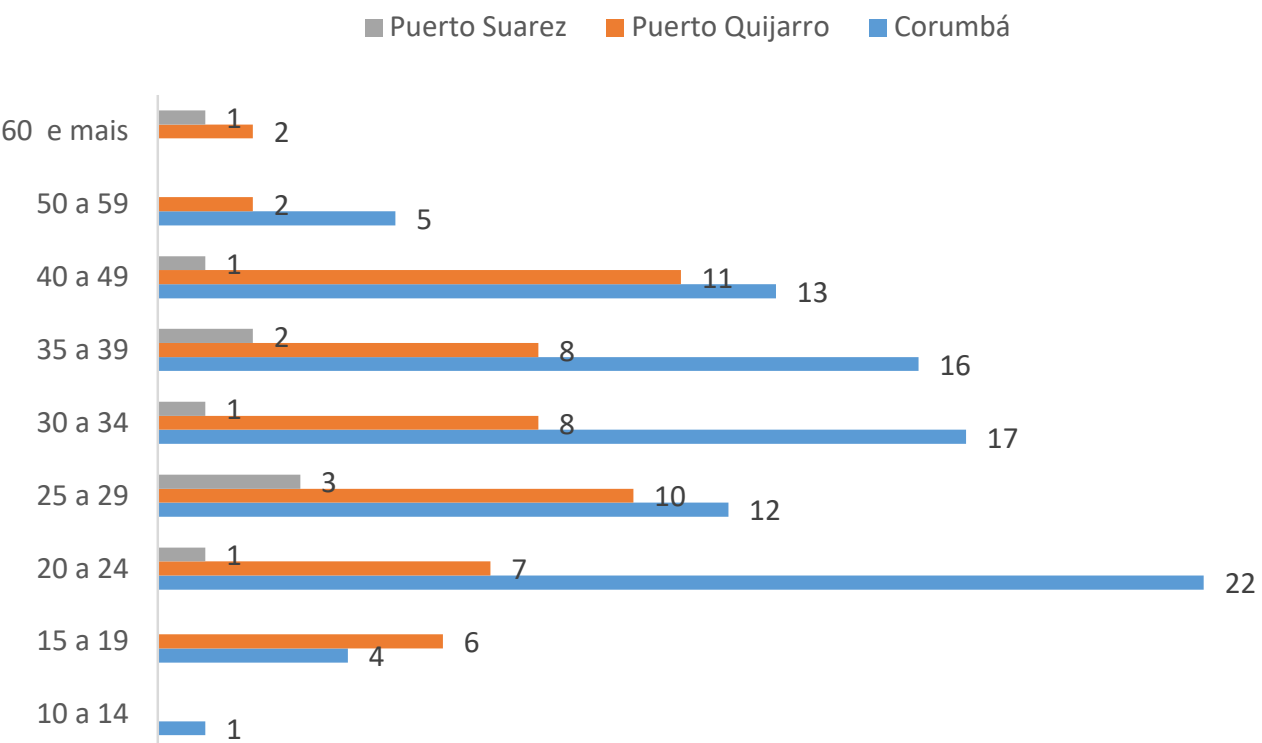

GRÁFICO 31 - Total de mulheres segundo faixa etária distribuída em Corumbá, Puerto Quijarro e Puerto Suarez, período de abrangência corresponde a 15 a 23 de março de 2013.

Fonte: Questionário 04 (Perfil socioeconômico)

Elaboração: SOKEN, D., março de 2013.

Com base na FIGURA “Total de mulheres distribuída em Corumbá, Puerto Quijarro e Puerto Suarez por local de nascimento, referente ao setor de comércio varejista” é possível afirmar que as cidades fronteiriças absorveram rotas de deslocamento populacional diferenciadas, por exemplo, as cidades de Puerto Suarez e Puerto Quijarro têm maior representatividade de mulheres provenientes de fora do departamento de Santa Cruz.

\footnotetext{
${ }^{101}$ Tanto na cidade de Corumbá quanto nas cidades bolivianas na fronteira é comum encontrar crianças no comércio popular de famílias bolivianas. Nota-se que a presença dos filhos na atividade comercial faz parte do processo de educação financeira familiar, tais crianças aprendem a dar troco, a oferecer os produtos em exposição, além disso, brincam ao redor das bancadas de mercadorias de outras famílias, e sempre estão acompanhadas de pais ou conhecidos.
} 
Observa-se que o comércio de longa distância nessa faixa de fronteira acontece desde de 1973, pois algumas dessas trabalhadoras que estão nessa atividade há mais de quarenta anos são provenientes de várias localidades da Bolívia, com destaque as mulheres de La Paz que totalizam 09, de Oruro com participação de 05 e, sobretudo, as cruceñas representam 11 trabalhadoras que atuam nas cidades bolivianas de fronteira. Além disso, percebe-se que a partir da década de 1990 houve maior migração de mulheres do altiplano boliviano para essa faixa de fronteira, registrou-se 04 que vieram de Cochabamba, 04 de Potosi e 02 de Sucre.

Cabe dizer que das 39 entrevistadas nascidas em Corumbá, 06 são descendentes de boliviana. Outras 05 trabalhadoras que atuam na cidade de Corumbá são originárias das cidades do estado de Mato Grosso do Sul, com maior presença de mulheres nascidas na região sudoeste do estado. E também foram encontradas 02 mulheres, uma peruana e outra da Colômbia que trabalham no comércio popular de Corumbá.

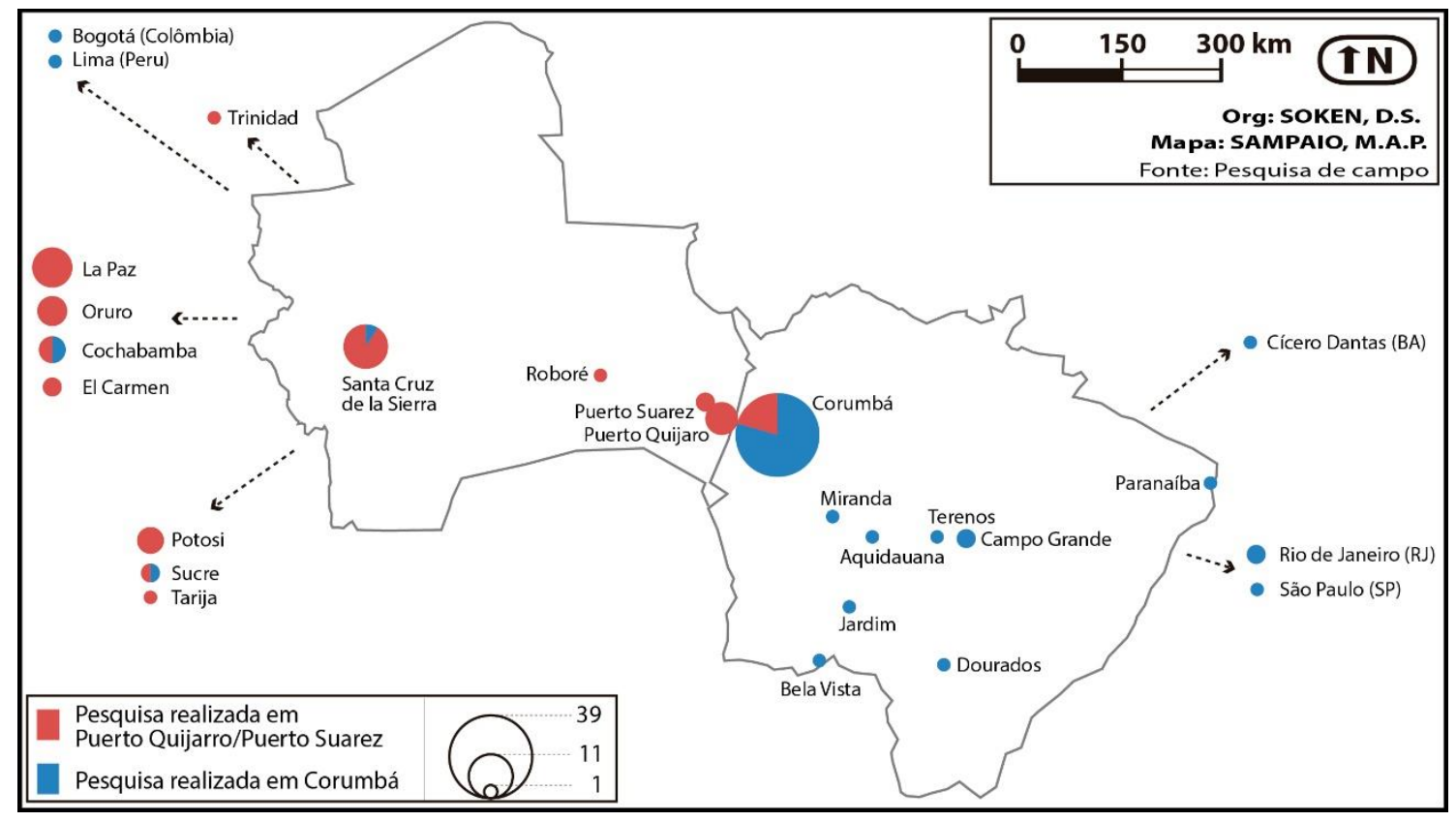

FIGURA 9 - Total de mulheres distribuída em Corumbá, Puerto Quijarro e Puerto Suarez por local de nascimento, referente ao setor de comércio varejista. Período de abrangência corresponde a 15 a 23 de março de 2013.

Fonte: Questionário 04 (Perfil socioeconômico)

Organização: SOKEN, D., março de 2013.

Elaboração: SAMPAIO, M.A.P.

De acordo com as mulheres entrevistadas que trabalham em Puerto Quijarro e Puerto Suarez, o motivo desse deslocamento para as cidades bolivianas na fronteira é porque em Santa Cruz de La Sierra há pouca oportunidade de trabalho para pessoas com 
idade acima de 30 anos, aquelas jovens com estudo secundário até encontram emprego nos serviços de telefonia e nos escritórios petroleiros. A competitividade no mercado de trabalho em Santa Cruz de La Sierra é mais elevada e o custo de vida também é alto, enquanto que na cidade de Puerto Suarez tanto a competitividade quanto o custo de vida são considerados mais baixos. As observações são distintas para as cidades de Corumbá e Puerto Quijarro, especialmente Arroyo Concepción, onde o custo de vida é considerado mais alto, tais lugares concentram as atividades comerciais e de serviços dessa faixa de fronteira.

Conforme as entrevistadas, relataram que não é fácil encontrar trabalho na fronteira, porque os contratos são estabelecidos entre familiares ou entre amigos. Geralmente, aquelas que vêm de outras localidades buscam contatos pré-determinados por familiares ou conhecidos na fronteira. As relações comerciais na área de fronteira são mediadas pela confiança. Aquelas que vêm de localidades distantes e sem contatos pessoais pouco ou nada conseguem se inserir produtivamente.

No que diz respeito ao nível de escolaridade das mulheres pesquisadas, verificouse que a maioria tem ensino médio completo cerca de 33 mulheres foram encontradas em Corumbá e 30 em Puerto Quijarro. No entanto, aquelas que têm ensino superior somam 29 mulheres, onde 28 se encontram em Corumbá. Outras que estão cursando o ensino superior totalizam 27 mulheres, sendo que apenas 7 trabalham em Puerto Quijarro.

Verificou-se que o nível de escolaridade das mulheres pode alterar a dinâmica do mercado de trabalho das cidades-gêmeas. Parafraseando Santos (1979, p.162), há atividades que vão exigir mais qualificação e capital, outras nem qualificação e nem capital. Com destaque de alguns dados, a atividade comercial absorveu 49 trabalhadoras de um total de 66 mulheres pesquisadas com ensino médio completo, dentre as comerciárias/comerciantes 18 trabalhavam em Corumbá e 31 trabalhavam nas cidades bolivianas. Já as atividades de serviços incorporaram 15 mulheres com ensino médio completo, sendo que a maioria se encontravam em Corumbá, total de 13 contra $02 \mathrm{em}$ Puerto Suarez.

Cabe dizer que as trabalhadoras com nível superior completo estão melhor inseridas nas atividades desenvolvidas em Corumbá, no comércio estavam trabalhando 11 mulheres, participaram 13 prestadoras de serviços e na indústria foi encontrado 04 mulheres. É relevante observar que, as mulheres com nível superior incompleto em Puerto 
Quijarro, 06 trabalhavam no Centro Comercial 12 de Octubre e 01 trabalhava em restaurante na avenida Luis Salazar.

\begin{tabular}{|c|c|c|c|c|}
\hline \multirow{2}{*}{ Nível de Escolaridade } & \multicolumn{3}{|c|}{ Lugar da pesquisa } & \multirow[b]{2}{*}{ Total } \\
\hline & Corumbá & Puerto Quijarro & Puerto Suarez & \\
\hline Analfabeta & 0 & 0 & 0 & 0 \\
\hline 1ㅇ completo & 2 & 5 & 2 & 9 \\
\hline 10 incompleto & 6 & 8 & 2 & 16 \\
\hline 20 completo & 33 & 30 & 3 & 66 \\
\hline 20 incompleto & 1 & 3 & 2 & 6 \\
\hline 3으 completo & 28 & 1 & 0 & 29 \\
\hline 3으 incompleto & 20 & 7 & 0 & 27 \\
\hline Total & 90 & 54 & 9 & 153 \\
\hline
\end{tabular}

TABELA 16 - Total de mulheres segundo nível de escolaridade distribuído por lugar, período de abrangência corresponde a 15 a 23 de março de 2013.

Fonte: Questionário 04 (Perfil socioeconômico)

Elaboração: SOKEN, D., março de 2013.

Em relação aos motivos de trabalhar na área de fronteira: a opção "melhor remuneração da atividade" foi mencionada por 47 mulheres, a maioria; 30 mulheres escolheram a opção "primeiro emprego ou negócio"; outras 32 mulheres disseram estar na atividade porque "gostam"; 17 pelo fato de "ser tradição familiar"; dentre outros motivos apontados pelas mulheres está a vantagem de trabalhar nas cidades-gêmeas.

\begin{tabular}{|c|c|c|c|c|c|c|c|c|c|c|}
\hline \multirow[b]{2}{*}{ Lugar da pesquisa } & \multicolumn{10}{|c|}{ Motivos } \\
\hline & 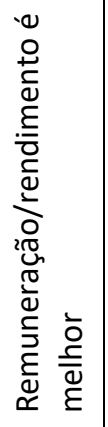 & 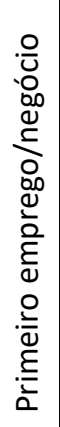 & 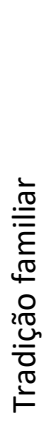 & $\begin{array}{l}\tilde{D} \\
\stackrel{5}{0} \\
\stackrel{0}{0}\end{array}$ & 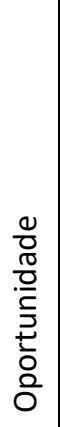 & 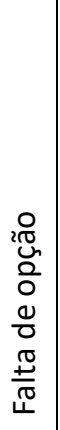 & 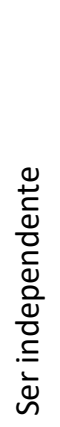 & $\begin{array}{l}\frac{0}{0} \\
\frac{0}{0} \\
\frac{0}{0} \\
0 \\
0\end{array}$ & $\begin{array}{l}n \\
0 \\
\frac{0}{ \pm} \\
0 \\
0\end{array}$ & $\begin{array}{l}\bar{\pi} \\
\stackrel{0}{0} \\
\qquad\end{array}$ \\
\hline Corumbá & 23 & 19 & 10 & 23 & 0 & 4 & 0 & 0 & 11 & 90 \\
\hline Puerto Quijarro/Puerto Suarez & 24 & 11 & 7 & 9 & 2 & 4 & 3 & 3 & & 63 \\
\hline Total & 47 & 30 & 17 & 32 & 2 & 8 & 3 & 3 & 10 & 153 \\
\hline
\end{tabular}

TABELA 17 - Total de mulheres segundo motivos de trabalhar na área de fronteira distribuída em Corumbá, Puerto Quijarro e Puerto Suarez, período de abrangência corresponde a 15 a 23 de março de 2013.

Fonte: Questionário 04 (Perfil socioeconômico)

Elaboração: SOKEN, D., março de 2013.

Uma outra característica das mulheres que trabalham na área de fronteira diz respeito ao estado civil, constatou-se que $64 \%$ das mulheres bolivianas são casadas e $21 \%$ 
são solteiras; já entre as brasileiras o percentual de solteiras é de 34\% e o de casadas é $45 \%$.

Observa-se que a maioria das mulheres brasileiras que estão casadas diz que cabe aos maridos as despesas mais caras, como aluguel, prestação do carro ou casa, enquanto que as mulheres bolivianas são as responsáveis pelo sustento de toda a família, além de realizar os investimentos em imóveis e/ou educação dos filhos, uma vez que elas são donas do próprio negócio e conseguem acumular mais capital do que as brasileiras.

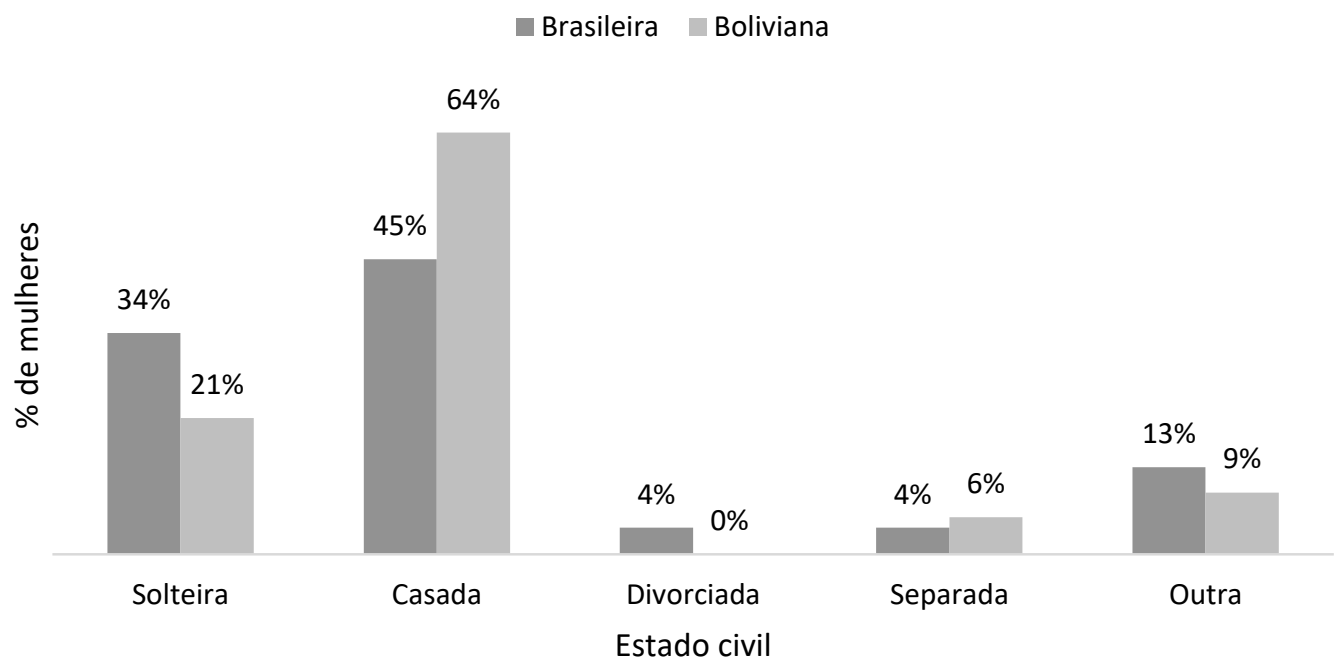

GRÁFICO 32 - Mulheres que trabalham nas cidades-gêmeas de fronteira, segundo estado civil, por nacionalidade, referente ao período de 15 a 23 de março de 2013.

Fonte: Pesquisa de campo, março de 2013

Organização: Dirce Soken

Em termos gerais, essas cidades-gêmeas de fronteira apresentam unidades territoriais de acumulação pautadas no comércio de produtos populares e de alta elasticidade-preço da demanda, ou seja, os preços baixos atraem os fluxos de pessoas e mercadorias para os dois lados da fronteira. Dando a entender que a 'fronteira informacional' tem a sua 'forma-conteúdo' delimitada pelas relações familiares, cujo domínio de técnicas "domésticas" de mercado transforma em informação apropriada por poucos nessa localidade da pesquisa. À luz de Milton Santos é possível dizer que a 'fronteira informacional', graças às horizontalidades, segundo ele, quando "há extensões formadas de pontos que se agregam sem descontinuidades" tem como tendência formar espaços de um cotidiano homólogo (SANTOS, 2006, p. 284 e 288).

Para tanto, percebe-se que a forma de organização espacial do trabalho feminino é uma questão determinante para o processo de acumulação mercantil desse espaço 
transfronteiriço. Desta forma, pretende-se descrever como essas mulheres produzem e reproduzem esse espaço de fronteira internacional entre Brasil-Bolívia.

\subsection{As práticas comerciais Aymaras e as mulheres "cama adentro" na fronteira entre Brasil e Bolívia}

As mulheres do comércio popular da fronteira organizam o território com base nos arranjos familiares e de amizades construídos ao longo de uma vida. Portanto, as práticas comerciais transfronteiriças serão interpretadas a partir das entrevistas realizadas nos diversos locais das cidades-gêmeas de fronteira entre Brasil e Bolívia. Dentre essas práticas destacam-se as formas e o tempo necessário para realizá-las. Para organizar as informações deste capítulo, levou-se em consideração a formação do capital social, organizado por meio dos contatos pessoais entre as comerciantes ${ }^{102}$.

Nessa pesquisa, tratou-se de descrever algumas rotas de migração que trouxeram essas mulheres à fronteira entre Brasil e Bolívia. Para isso, foram buscadas informações, a partir das entrevistas ${ }^{103}$, sobre os motivos que levaram essas mulheres a atuarem na atividade comercial, bem como, a compreender as formas e estratégias que foram adotadas para trabalhar nas cidades-gêmeas de fronteira.

Revelou-se durante as entrevistas um acumulado de experiências de trabalho, tais como: mulheres que atuavam em atividades agrícolas e no comércio de produtos diversos; outras que trabalhavam em ambientes mais competitivos e foram excluídas pelo fato de estarem acima da faixa etária de trinta anos e, além daquelas que vieram de um processo de migração mais complexo, onde a rota começa dentro do país para depois chegar até as áreas de fronteira.

\footnotetext{
${ }^{102}$ De acordo com Karsten e Meertens (1992, p.187 e 188) o planejamento urbano ou regional está pautado nas atividades setoriais, onde nem sempre é considerado a praticidade humana da vida cotidiana, no caso do cotidiano da mulher e o habitat urbano estabelecem obstáculos para a participação da mulher no mercado de trabalho. Portanto, as mulheres participam de rede social, porque elas conseguem apoio e solidariedade recíproca pela luta da sobrevivência.

${ }^{103} \mathrm{O}$ roteiro das entrevistas está no Apêndice B dessa tese.
} 
Em Puerto Quijarro, verificou-se que as empresas de agronegócios, os serviços portuários e o transporte de mercadorias empregam mão de obra masculina ${ }^{104}$, tal fato justificou em parte a entrada das mulheres no comércio da fronteira; outro fator que explicou tal concentração de mulheres no comércio da fronteira é a dificuldade de encontrar trabalho no interior da Bolívia, e até mesmo o fato de a atividade comercial dos grandes centros comerciais já não comportar pequenos comerciantes de produtos populares. As cidades de Santa Cruz de la Sierra, La Paz e Cochabamba que concentram o comércio atacadista e varejista de produtos populares e distribuem para todos os confins da Bolívia.

No caso de Corumbá, percebe-se uma estratégia comercial muito comum na área de fronteira, que se refere ao investimento duplicado, pois muitas mulheres comerciantes atuam em ambos os dois lados fronteiriços. Essa situação é comum em regiões de fronteira uma vez que as pessoas atravessam diariamente os limites nacionais e criam arbitragens oportunistas, ou seja, possibilitam o uso dos diferenciais políticos e econômicos existentes nas relações transfronteiriças ${ }^{105}$.

$\mathrm{Na}$ zona de fronteira ${ }^{106}$, as atividades comerciais do circuito superior, ditas “impuras” (SANTOS, 1979, p. 67), responsáveis pela organização deste espaço fronteiriço, são do ramo da indústria de exportação de produtos minerais, como ferro, manganês e cimento, e do ramo do comércio de exportação e importação, com destaque para a soja, o gás natural da Bolívia e produtos alimentícios industrializados.

O transporte e o comércio de atacado, enquanto atividades do circuito superior do tipo "mistas", desempenham um importante papel na economia urbana das cidadesgêmeas da fronteira. São elementos que garantem a circulação de pessoas e mercadorias entre os dois circuitos econômicos, e podem criar uma possibilidade de especialização

\footnotetext{
${ }^{104}$ A média salarial dos homens bolivianos é de Bs\$ 8.000,00 (oito mil bolivianos), para efeito de comparação equivale a US\$1.230,00 (um mil e duzentos e trinta dólares), conforme cotação da moeda americana em 15 setembro de 2014.

${ }^{105}$ Segundo em Steiman e Machado (2002. p.13), "Mais difíceis de mensurar, devido à relativa imobilidade comparada à alta mobilidade dos trabalhadores, são os fluxos de capital. Sujeita a variações conjunturais constantes, induzidas pelas diferentes políticas econômicas e cambiais de cada país, a zona de fronteira" 106 Conforme o Ministério da Integração, "o conceito de zona de fronteira aponta para um espaço de interação, uma paisagem especifica, um espaço social transitivo, composto por diferenças oriundas da presença do limite internacional, e por fluxos e interações transfronteiriças, cuja territorialidade mais evoluída é a das cidades-gêmeas". Acessado em 29/10/2006 www.igeo.ufrj.br/gruporetis/programafronteira/tikiindex.php?page=FAIXA+E+ZONA+DE+FRONTEIRA
} 
produtiva nestas áreas fronteiriças. Tal peculiaridade dessas cidades-gêmeas em estudo será explicada no capítulo seguinte.

Sendo assim, com base nas entrevistas realizadas foram relacionadas apenas as mulheres que tiveram suas experiências profissionais pautadas pela atividade do comércio. Além disso, se destacaram aquelas que chegaram à fronteira com capital e outras que por falta de trabalho nas localidades de origem se deslocaram até as cidadesgêmeas de fronteira e conseguiram construir seus 'espaços'.

Com o objetivo de preservar a identidade dessas mulheres entrevistadas far-se-á uso de pseudônimos de origem Aymara.

A seguir cabe a descrição dos relatados referentes aos motivos sobre as formas e estratégias comerciais que cada uma utilizou nas cidades-gêmeas da fronteira internacional com o propósito de garantir seu espaço econômico, familiar e social.

\subsubsection{As trabalhadoras bolivianas nas cidades-gêmeas fronteiriças}

Com base no relato da senhora Kusisa ${ }^{107}$, de 52 anos, pode-se perceber que o tempo de atuação no comércio de fronteira é um fator determinante para permanência de muitas mulheres nessa localidade. Ela veio de Cochabamba e trabalha no comércio da fronteira há vinte e seis anos. Quando morava em Cochabamba era professora de biologia e a convite da irmã, que já trabalhava no comércio em Arroyo Concepción, chegou à fronteira em 1988, associou-se ao grupo de comerciantes que fundou o Centro Comercial 12 de Octubre e começou a vender roupas.

Faz apenas dois anos que está trabalhando integralmente no comércio, pois conseguia associar sua profissão de professora de biologia com a atividade comercial, durante vinte e quatro anos trabalhou meio período em cada atividade. Tinha uma funcionária na casseta ${ }^{108}$ que ficava somente meio período. Segundo, senhora Kusisa, há

\footnotetext{
${ }^{107}$ Nome Aymara que significa alegre

108 São conhecidos por "boxes" ou "baias", são espaços que medem entre oito a dez $\mathrm{m}^{2}$ destinado ao comércio de produtos diversos, reunidos num único espaço de circulação, nesse exemplo é no Centro Comercial 12 de Octubre em Arroyo Concepción, Puerto Quijarro.
} 
cerca de dois anos teve que dispensar a menina porque o movimento do comércio caiu significativamente e reduziu as vendas.

Logo que chegou à fronteira a senhora Kusisa encontrou muita dificuldade, com o dinheiro que tinha acumulado em Cochabamba investiu em roupas e viagens, porque antes tinha que viajar com mais frequência do que hoje para adquirir as mercadorias, percorria muitas localidades no altiplano boliviano para encontrar o melhor preço.

Com o seu trabalho no comércio e com a renda do marido que também é comerciante de vestuário conseguiu se estabelecer em Puerto Quijarro e possibilitar às filhas cursos de graduação em Santa Cruz de la Sierra, onde moram atualmente. Tão breve, a senhora Kusisa pretende deixar o comércio da fronteira e morar em Santa Cruz de la Sierra. "Aqui já foi bom, dá para ganhar um pouco, mas tem que se sacrificar muito, trabalhar muito, acordar cedo", desabafou a comerciante.

Outro relato é da senhora Silluka ${ }^{109}, 48$ anos, que nasceu em Cochabamba e veio para fronteira no ano de 2001 porque soube que nesse local circulava muito dinheiro, realidade bem diferente do comércio de Cochabamba. Segundo senhora Silluka, nessa localidade vende-se muito mais. A comerciante tem dois filhos, o primeiro já é engenheiro e trabalha com o pai, outro ainda está estudando em Cochabamba, mas os dois pretendem ficar e trabalhar aqui na fronteira.

Atualmente comercializa malas, bolsas, brinquedos, entre outros acessórios e está instalada num prédio comercial próprio na Calle German Bush em Arroyo. Senhora Silluka pretende aumentar mais um piso para servir de sua residência, pois acredita que essa fronteira ainda pode melhorar, vai continuar investindo. Seu marido trabalha na construção civil, no momento reduziram os investimentos porque as construções dependem das vendas do comércio que diminuíram.

É fato que o sacrifício do deslocamento relatado por ambas diz respeito ao trabalho produtivo dessas mulheres aliado ao propósito de garantir aos seus filhos tempo suficiente de permanência nas instituições de ensino, unidade de extensão do trabalho doméstico. A expectativa de conseguir uma colocação dos filhos na indústria petroleira boliviana faz com que muitos tenham que poupar recursos retirados do comércio da

\footnotetext{
${ }^{109}$ Nome Aymara que significa mãos bonitas
} 
fronteira para destinar a pagamento de mensalidades e moradia estudantil em Santa Cruz de la Sierra e em Cochabamba.

Articulado à elevação dos negócios na fronteira, o crescimento do número de instituições de ensino da Bolívia chegou até a fronteira, há pelo menos duas instituições bolivianas de ensino superior bolivianas que oferecem cursos na área da saúde, como medicina e enfermagem e na área jurídica.

\subsubsection{Os investimentos duplicados nas cidades-gêmeas Corumbá (Mato Grosso do Sul), Puerto Quijarro e Arroyo Concepción (departamento de Santa Cruz)}

Com base nas entrevistas foi possível identificar pelo menos três mulheres comerciantes que realizaram investimentos duplicados, a senhora Atipaj ${ }^{110}, 42$ anos, a senhora Kallpa ${ }^{111}, 44$ anos e a senhorita Sipaku ${ }^{112}$ que tem 20 anos.

A senhora Atipaj é paceña ${ }^{113}$, veio para Corumbá com doze anos e trabalhou nas ruas como ambulante, vendia alho, feijão, leite em pó, balas, chicletes, cigarros, entre outros produtos, em sua maioria, adquiridos da Bolívia. Segundo senhora Atipaj esse tipo de comércio era muito comum nas ruas Joaquim Murtinho e Treze de Junho, os clientes corumbaenses eram atraídos pelo alho vermelho e o feijão boliviano e acabavam comprando também outros produtos alimentícios e industrializados no geral.

Aprendeu a trabalhar no comércio com a mãe. Quando seu pai faleceu tinha oito anos e teve que ajudar a mãe vendendo produtos na rua. Aos dez anos já acumulara certa quantia em dinheiro para comprar suas "coisinhas". Quando jovem, aos dezesseis anos sua mãe lhe ofereceu uma quantia em dinheiro que usou para adquirir mercadorias em Santa Cruz de la Sierra e ampliar suas vendas no comércio ambulante.

Trabalhou durante dez anos oferecendo produtos nas ruas de Corumbá, casou-se, teve três filhos, conseguiu comprar um terreno no bairro Dom Bosco e construiu sua casa. Entre os anos de 1993 e 1994 teve todas as mercadorias confiscadas pela Polícia Federal, levaram de dentro da sua casa os produtos que estavam guardados, como: cigarros,

\footnotetext{
${ }^{110}$ Nome Aymara que significa vencedora

${ }^{111}$ Nome Aymara que significa esforçada.

112 Nome Aymara que significa boa moça.

${ }^{113}$ Nascida na cidade de La Paz, Bolívia.
} 
fraldas, alho, feijão, leite em pó, confiscaram até a bicicleta do filho, inclusive a televisão de uso pessoal. A partir daquele dia, a senhora Atipaj decidiu que não iria morar em Corumbá, vendeu sua casa a um valor bem abaixo do mercado e se mudou para Arroyo Concepción. Lá conseguiu comprar uma “casseta” no Centro Comercial 12 de Octubre e onde atualmente vende roupas para adultos e crianças.

A senhora Kallpa, 44 anos, nasceu em Yacuíba, fronteira da Bolívia com a Argentina, foi para Santa Cruz de La Sierra com doze anos, engravidou, deixou a escola e desde os 13 anos de idade sobrevive da atividade comercial, que iniciou como ambulante em Santa Cruz, lá vendia de porta em porta cosméticos de baixo preço e de fácil acesso. Aprendeu a viver do comércio autônomo, segundo Kallpa, foi a necessidade daquele momento que a fez entrar na área comercial e a partir da rotina do trabalho aprendeu a negociar.

Senhora Kallpa explicou que para vender no mercado boliviano era preciso buscar produtos de boa rotatividade e melhores preços. Segundo a comerciante, encontrou no ramo de cosméticos com a linha de perfumes importados o melhor negócio. Na década de 1990 se deslocou até a fronteira com o Brasil e se especializou na venda de perfumes importados, logo se instalou no lado brasileiro, e na feira BRASBOL vendia seus cosméticos.

Em 1998 a Associação da feira BRASBOL tornou-se uma empresa e passou a exigir notas fiscais de aquisição de mercadorias de todos os seus associados, essa mudança a fez trocar de ramo e começou a vender roupas procedentes das cidades de São Paulo e Goiânia, mas as roupas que trazia de Santa Cruz de la Sierra eram as mais vendidas. Senhora Kallpa lamentou o fechamento do comércio da BRASBOL, o que a fez desalugar a "casseta" no Centro Comercial 12 de Octubre para continuar trabalhando com o comércio de roupas. Hoje, mora em Corumbá com os cinco filhos e o marido numa casa construída com o trabalho de quinze anos de comércio na BRASBOL e trabalha no comércio de vestuário em Arroyo Concepción.

A senhorita Sipaku é neta de agricultores bolivianos, nasceu em Corumbá e trabalha no comércio de produtos populares com a família. A mãe veio de Sucre, capital boliviana, para Corumbá na década de 1990, a convite de uma tia que trabalhava no comércio da fronteira. Começou a trabalhar nas ruas no centro da cidade vendendo alho 
e feijão boliviano, nesse período sua mãe tentou trabalhar na BRASBOL, mas não permitiram a entrada de outros comerciantes de fora do círculo de relações do grupo instalado. Seguiu vendendo produtos alimentícios in-natura e industrializados na rua como ambulante. Depois, conseguiu alugar a garagem de uma casa no centro de Corumbá, deixou de vender na rua, mas ficou durante sete anos nessas condições. Com a ajuda dos filhos conseguiu alugar o salão comercial que fica localizado na área central de grande fluxo de pessoas, onde oferece desde produtos alimentícios a industrializados diversos.

Atualmente toda a família de Sipaku, a mãe, a irmã, e o irmão dividem o espaço do salão comercial com a residência de dois quartos, nos últimos anos o valor negociado do aluguel sofreu uma alta significativa, de oitocentos reais que pagava pela garagem passou para mil e duzentos reais em dois anos e hoje paga dois mil reais. Para fechar o contrato de aluguel do salão teve uma série de contratempos. Primeiro o contrato foi negociado pelo procurador do proprietário, que não fazia questão de fechar a proposta. Depois foi feita uma contraproposta oferecida pela comerciante concorrente, isso fez triplicar o valor do aluguel. Consequentemente, não foi possível exigir melhores condições das instalações do prédio, que foi alugado sem a devida reforma, a qual the garantiria segurança e conforto. Há promessas do proprietário de realizar alguns reparos, como pintura e pequenas reformas nos demais cômodos.

Considerando as dificuldades que a família encontrou para se instalar adequadamente na cidade de Corumbá, a mãe da senhorita Sipaku conseguiu, há quinze anos, com seu trabalho de comerciante ambulante adquirir um terreno em Puerto Quijarro. $\mathrm{Na}$ época o terreno não valia muito, hoje corresponde ao triplo do valor. Com a renda do comércio está construindo uma casa do outro lado da fronteira para alugar.

Sobretudo, o comércio popular de Corumbá oferece a essa família renda suficiente para bancar a mensalidade da faculdade de Direito para senhorita Sipaku. Foi possível adquirir um carro e com o trabalho realizado pela a mãe de 45 anos é garantida a subsistência de toda a família.

A partir dos dados da pesquisa, observa-se que entre 7\% a 9\% de mulheres jovens e experientes apontam que a remuneração da atividade é o principal motivo de trabalhar na área de fronteira. Entre aquelas que tem entre 25 a 29 anos consideram que o primeiro emprego ou negócio (5\%) e por ser atividade familiar $(5 \%)$ destacam como motivo 
principal de sua escolha por trabalhar na fronteira o fato de se tratar de uma atividade familiar.

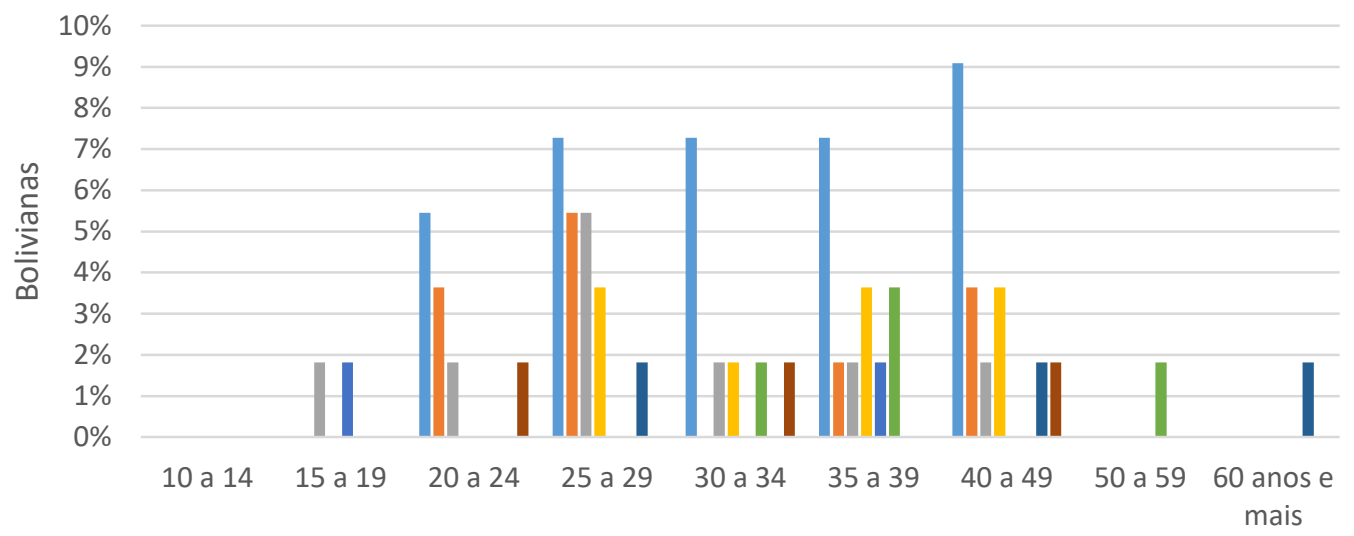

Faixa etária

\begin{tabular}{|c|c|}
\hline - Tradição familiar & Gosta \\
\hline - Oportunidade & - Falta de opção \\
\hline - Ser independente & - Liberdade \\
\hline
\end{tabular}

GRÁFICO 33 - Porcentagem de mulheres bolivianas segundo faixa etária e por principal motivo de trabalhar na área de fronteira, período de 15 a 23 de março de 2013.

Fonte: Questionário 04 (Perfil socioeconômico)

Elaboração: SOKEN, D., março de 2013.

A razão da inserção dessas mulheres no comércio autônomo é porque encontram compatibilidade entre o tempo do trabalho produtivo e o trabalho reprodutivo. Buscaram estabelecer a duplicidade de investimento em razão das melhores condições do lado brasileiro, onde há instituições que garantem a reprodução do trabalho doméstico, como creche, escola, hospital e sobretudo, os serviços são disponibilizados gratuitamente, porque a grande maioria tem filhos brasileiros.

Além disso, a atuação dessas mulheres na fronteira mostra a conquista do seu próprio espaço, portanto, revela sua nova identidade feminina, que é essa capacidade de formar redes sociais com poder de articular o território. 


\subsubsection{As trabalhadoras brasileiras nas cidades fronteiriças da Bolívia}

Foi no final da década de 1980 que a senhora Wayra ${ }^{114}, 52$ anos, desenvolveu atividades de comércio e serviço nas cidades-gêmeas de fronteira. Ela é cearense, foi para a capital paulista com dezoito anos, lá trabalhou de empregada doméstica, de garçonete e ajudante de cozinha e depois de costureira de fábrica. No ano de 1989 decidiu tentar a sorte na Bolívia, migrou para Corumbá, onde morou por oito meses e depois foi para Puerto Suarez. Ao longo dos vinte e cinco anos que mora e trabalha com o marido em Puerto Suarez já teve vários negócios, restaurante, discoteca, karaokê, padaria e atualmente tem uma pizzaria, onde trabalha no período noturno na cidade portenha. Durante a jornada diurna trabalha no comércio de roupas em Arroyo Concepción, onde aluga uma casseta no Centro Comercial 12 de Octubre.

Seu conhecimento sobre o comércio da fronteira foi por contatos pessoais estabelecidos no local, por meio de conversas e informações que recebia de alguns comerciantes brasileiros e bolivianos, onde estabeleceu mais laços de confiança mais com os brasileiros. Porque na fronteira, as relações entre os próprios bolivianos são distintas. Os bolivianos da parte ocidental (do altiplano) são mais restritivos, realizam negócios somente com familiares e amigos, as informações e os melhores negócios circulam entre eles.

A senhora Wayra é enfática ao falar da fronteira como um lugar tranquilo para morar e, quanto ao trabalho, relatou que teve mais oportunidades de negócios em Puerto Suarez e Puerto Quijarro porque considera que é mais fácil ter seu próprio negócio. É preciso ter um certo volume de dinheiro para obter as mercadorias e não tem outros custos além do aluguel para pagar. Acredita que se estivesse ainda no Brasil não teria condições de oferecer às filhas o ensino superior, hoje uma é engenheira ambiental e outra farmacêutica e atualmente moram e trabalham em Santa Cruz de La Sierra.

A senhora Mayta ${ }^{115}$, 51 anos, é corumbaense. Trabalha há vinte e dois anos em Puerto Quijarro numa loja de cosméticos importados cuja dona é brasileira e também mora em Corumbá. É solteira, mora com o filho de 24 anos, com os pais aposentados e três irmãos. Quando seus irmãos e filho eram crianças foi arrimo de família e hoje com

\footnotetext{
${ }^{114}$ Nome Aymara que significa veloz como o vento

115 Nome Aymara que significa primogênita
} 
seu trabalho no lado boliviano e com a ajuda do filho e irmãos conseguiram comprar uma casa em Corumbá.

Afirma que a remuneração e o conforto de trabalhar na loja de cosméticos são muito bons e isso atrai muitas trabalhadoras bolivianas que deixam currículos na loja, a maioria são quijarrenhas. A senhora Mayta considera que o setor de cosméticos oferece mais oportunidades de trabalho para as mulheres brasileiras e bolivianas no lado boliviano da fronteira. No entanto, acredita que a proposta de trabalho aqui não atraia tanto as brasileiras pelo fato de o contrato trabalhista boliviano não servir para comprovar tempo de trabalho no Brasil, somente se consegue fazer o pagamento da previdência. Isso é um fator que não atrai as trabalhadoras brasileiras.

A senhora Yupanki ${ }^{116}, 45$ anos, nasceu em Ladário e mora em Corumbá. Há dezesseis anos trabalha em Puerto Quijarro numa empresa familiar de corumbaense, onde desde jovem (aos dezenove anos) já era funcionária da loja em Corumbá. Assim que se casou e teve filhos se afastou do mercado de trabalho no qual realizava jornada de oito horas diárias e passou a trabalhar para a mesma empresa com contrato temporário, cobria os dias de férias ou licenças de funcionários.

A senhora Yupanki prontamente aceitou a oferta de trabalhar no lado boliviano, porque após ter criado os filhos, foi difícil retornar ao mercado de trabalho. A comerciária observa que em Puerto Quijarro é bom apenas para trabalhar, apesar do custo de vida para o brasileiro que lá trabalha é baixo. Diz prefere morar em Corumbá porque os parentes moram lá.

Embora ganhe menos que o marido, considera que ao trabalhar no comércio pode garantir sua independência financeira, caso rompa o laço matrimonial, argumentou sra. Yunpaki. Ao longo dos 16 anos que trabalha em Puerto Quijarro, a sra. Yunpaki nunca soube de roubos ou violência com trabalhadores. Segunda ela, existe uma cooperação entre os comerciantes e comerciários quanto às informações de segurança na fronteira, seja a respeito de dólares falsos ou fechamento da fronteira.

\footnotetext{
${ }^{116}$ Nome Aymara que significa honrada
} 
Entre um corredor e outro estava a senhora Illika ${ }^{117}$, ambulante vendedora de salgados e "quentinhas" no Centro Comercial 12 de Octubre, ela tem 42 anos nasceu em Poconé no Estado de Mato Grosso. Veio para Corumbá em 1984. Logo seu marido faleceu e ela foi trabalhar na Brasbol vendendo salgados para as lojistas e também de diarista na casa das famílias bolivianas em Corumbá. Casou-se novamente há quinze anos atrás, seu marido é fillho de boliviano, trabalhou na Brasbol de carregador e montador de barracas. Considera que sua vida era melhor quando estava na Brasbol, tinha tempo para fazer cursos de culinária de salgados, fazia aulas de dança, não tinha que acordar de madrugada para atender os clientes e, sobretudo, ficava mais tempo com a família, ela tem cinco filhos.

Depois que fecharam a Brasbol, a maioria dos lojistas se instalou em Arroyo Concepción, porque alguns já tinham casseta no Centro Comercial, outros alugaram salão comercial ao redor e a sra. Illika, que mora em Corumbá, atravessa a linha da fronteira todas as madrugadas para oferecer seus salgados e anotar pedidos para trazer as "quentinhas" ao meio-dia.

Segunda senhora Illika, desde que chegou a Corumbá, trabalha somente com comerciantes bolivianas, seja vendendo alimentos ou realizando serviços de faxina. E pelo fato de manter essa proximidade com essas comerciantes, também realiza serviço de faxina para as famílias que moram do lado boliviano.

Enfatiza a comerciante que hoje seu trabalho e com a ajuda do marido, que faz frete para os feirantes em Corumbá, consegue comprar uma casa na cidade de Corumbá, pagar as prestações do carro e principalmente bancar todas as despesas domésticas com o trabalho que realiza no comércio ambulante de alimentos e com as faxinas nas casas das famílias bolivianas.

A maioria das mulheres brasileiras que trabalham do lado boliviano está disposta a abrir mão dos benefícios sociais como a contagem de tempo de trabalho assinado em carteira pelo fato de que, na fronteira o pagamento de salários pode ser efetuado em moeda americana ou até mesmo em moeda brasileira, sem os descontos. Além da relação de confiança entre funcionária e proprietária da loja. Já aquelas que buscam trabalhar

${ }^{117}$ Nome Aymara que significa com sorte 
como autônomas no lado boliviano é porque necessita-se de pouco capital e baixa burocracia para realizar atividade comercial ou de serviços.

Com base nos dados da pesquisa, verificou que cerca de $7 \%$ a $8 \%$ das mulheres brasileiras conquistam seu primeiro emprego ou negócio na faixa etária de 15 a 24 anos. As mais experientes, cerca de $6 \%$ a $8 \%$ que estão na faixa etária de 30 a 39, apontaram que a remuneração da atividade é o motivo pelo qual escolheram trabalhar na área de fronteira.

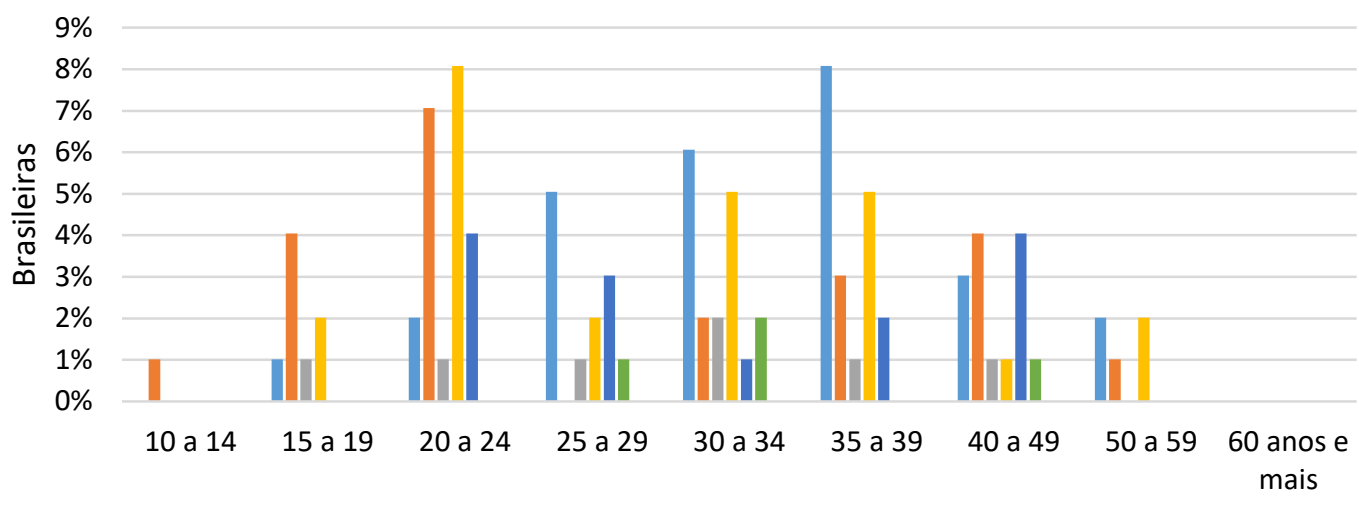

Faixa etária

$\begin{array}{ll}\square \text { Remuneração/rendimento é melhor } & \text { - Primeiro emprego/negócio } \\ \square \text { Tradição familiar } & \text { Gosta } \\ \square \text { Oportunidade } & \text { Falta de opção } \\ \square \text { Ser independente } & \text { Liberdade }\end{array}$

GRÁFICO 34 - Porcentagem de mulheres brasileiras segundo faixa etária e por principal motivo de trabalhar na área de fronteira, período de 15 a 23 de março de 2013.

Fonte: Questionário 04 (Perfil socioeconômico)

Elaboração: SOKEN, D., março de 2013.

A seguir, será descrito os relatos referente à jornada de trabalho das mulheres que atuam no comércio da fronteira. Observa-se que o tempo de trabalho realizado pelas mulheres bolivianas se diferencia das brasileiras pelo fato daquelas estarem mais capitalizadas, sobretudo, conseguem organizar o trabalho da família em torno da atividade principal.

O intenso fluxo comercial da fronteira ocorre entre os horários de quatro às seis horas da manhã. Isso acaba configurando um regime de trabalho excepcional que determina a rotina dessas mulheres que trabalham no comércio e, portanto, do lugar. 


\title{
3.2.3 A jornada de trabalho de regime excepcional da mulher boliviana
}

Senhora Atipaj, antes de retornar para o comércio autônomo, trabalhou dois anos de empregada doméstica, fazendo faxinas e também vendia como ambulante algumas roupas em Arroyo, ganhava muito pouco, cerca de um salário mínimo. Mas, conseguiu juntar um pouco de dinheiro e investiu em meias infantis e adultos, bonés, outros artigos, e assim, começou a trabalhar para ela mesma. Depois de uma longa jornada trabalhando, conseguiu comprar uma "casseta", com empréstimo que fez no banco.

Quando trabalhava de ambulante em Corumbá, a senhora Atipaj relatou que não era fácil trabalhar na rua, ficava sentada na calçada com os filhos, montava uma bancada na calçada e expunha as mercadorias, cigarros, balas, chicletes, todas as coisas cuja venda era rápida. Esse foi o seu trabalho até 1994, para ela naquele momento foi ruim ficar em Corumbá, porque não recebeu o devido valor pelo seu trabalho, desabafou senhora Atipaj:

\begin{abstract}
Judiaram de mim, tomaram todos as mercadorias, sem piedade, nem quiseram saber se é pobre, não se importavam. Não tinha um real para comprar pão para meus filhos, eles choravam atrás de mim... me separei de meu marido e ainda tive todas as mercadorias apreendidas... não sei como tive força para superar e sair daquela situação. Hoje, meus filhos me ajudam, tem um que era comerciante na BRASBOL, eu comprei um box lá para ele trabalhar (informação verbal).
\end{abstract}

Atualmente trabalha com o filho, sua rotina é ficar o dia todo na "casseta" à espera de clientes, sua jornada diária é de quinze horas. Abre a loja às quatro horas da madrugada e fecha às dezoitos horas. Seu filho vende suas mercadorias nas feiras de rua em Corumbá e nas ruas de Arroyo, também realiza as cobranças diariamente, além disso vai pelo menos uma vez na semana para Santa Cruz e no período do inverno vai para La Paz para trazer mercadorias.

A filha de dezoito anos da senhora Atipaj trabalha há dois anos em Campo Grande, recebe salário de oitocentos reais vendendo roupas que a mãe fornece para o dono da loja. No futuro, a senhora Atipaj pretende alugar um box para a filha e torná-la uma comerciante autônoma em Campo Grande, conforme argumentou:

Eu pretendo alugar uma loja para ela mesma trabalhar, assim posso fornecer as mercadorias diretamente para ela. Ela precisa começar a lucrar para ela, porque vai querer ter sua família e vai precisar dessa loja, não pode ficar a vida toda trabalhando para outra gente, só ganhando salário, as vezes o salário não alcança, porque no Brasil tudo é mais caro do que na Bolívia (informação verbal). 
Há cerca de um ano e meio a senhora Kallpa mantém sua rotina de ir até a linha de fronteira de segunda a sábado, lá dá início a sua jornada de trabalho na própria loja no Centro Comercial 12 de Octubre, onde começa a funcionar às seis e meia da manhã e só fecha às dezoito horas. Passa o dia todo à espera de clientes que vêm de longe. Na semana, apenas sábado é o dia que mais vende, aí tem ajuda de dois filhos que já são adolescentes. Nos demais dias organiza os negócios, faz os pedidos de mercadorias, faz trocas de moedas, mantém contatos com os clientes, sobretudo troca informações com as demais lojistas.

Segundo a senhora Kallpa quando estava no comércio na Brasbol trabalhou muito, durante quinze anos a jornada de trabalho era de doze horas de segunda a domingo, abria o comércio no feriado e até nas datas comemorativas de familiares. Argumentou senhora Kallpa "trabalhei sem medida, fiz isso até conseguir a minha casa, depois diminui, porque trabalhava demais. Tinha como estímulo a ansiedade de sair do aluguel, ter que mudar toda vez que o dono pedia a casa".

Apesar de tudo, a senhora Kallpa considera que a sua rotina de trabalho era melhor quando estava na Brasbol, porque sua casa estava próxima do trabalho, além do rendimento ser melhor do que do Centro Comercial 12 de Octubre. O preço de venda das mercadorias na Bolívia é menor e para ter o mesmo rendimento que tinha na Brasbol precisa vender muito. Como as principais clientes são sacoleiras e buscam preços mais baixos para revender, o ganho por peça é bem baixo entre um e dois reais. Já em Corumbá conseguia uma margem de ganho maior, porque os preços das mercadorias são cotados pelo mercado local que é mais elevado.

Quando as vendas durante a semana não são boas, senhora Kallpa recebe ajuda do marido que paga as contas de água, luz e telefone. Ele trabalha duas vezes na semana em Corumbá nas feiras livres vendendo roupas. Mas, a maior contribuição da renda da família vem da atividade comercial na Bolívia. Ela é a responsável por manter a alimentação de todos e a mensalidade da faculdade de um dos filhos que estuda engenharia de petróleo em Santa Cruz de La Sierra.

O comércio da família da senhorita Sipaku funciona de segunda a sábado nos horários de sete da manhã até as vinte horas, no domingo funciona até as treze horas. A rotina da srta. Sipaku e dos demais irmãos é fazer cotações de preços pela cidade, elaborar 
o preço final de venda, além de manter contatos com alguns comerciantes bolivianos para tratar de negócios e definição de preços.

A jornada de trabalho desse tipo de comércio é mais intensa entre os dias 1 e 15 do mês, que exige maior disponibilidade de tempo por parte dos filhos para o comércio, após esse período o fluxo diminui e a mãe da srta. Sipaku quem trabalha sozinha no restante dos dias.

Entre uma jornada e outra, o irmão da senhorita Sipaku é taxista e também realiza as compras de mercadorias para o estabelecimento comercial que tem na Bolívia. A renda do estabelecimento do irmão somada à atividade de taxista é maior do que a da mãe. Mas, percebe-se que outras mulheres bolivianas que têm comércio em Corumbá ganham mais do que a mãe e o irmão. A análise sobre as relações comerciais em Corumbá será discutida no capítulo seguinte.

\subsubsection{A jornada de trabalho de regime excepcional da mulher brasileira}

Há cinco anos a senhora Wayra trabalha em dois turnos, durante o dia no comércio de roupas no Centro Comercial 12 de Octubre, sua jornada diária pode variar de acordo com o movimento quando está fraco começa às $6 \mathrm{~h}$ e fecha às $18 \mathrm{~h}$, no frio a jornada é ampliada a loja é aberta às $4 \mathrm{~h}$ e fecha às $19 \mathrm{~h}$. À noite trabalha com o marido numa pizzaria em Puerto Suarez.

Senhora Mayta se desloca de segunda a sábado até a linha da fronteira, uma parte do percurso faz de ônibus interurbano e no lado boliviano pega um táxi em Arroyo e segue até o local de trabalho. Ela realiza todas as funções da loja, vende, arruma o estoque, atende no caixa, entre outras atividades, não existe uma hierarquia funcional entre as funcionárias. A jornada de trabalho é contínua e realizada nos períodos diurno e vespertino, pelo fato de ficar o dia todo no lado boliviano nunca conseguiu participar da vida escolar do filho.

A senhora Yunpaki realiza todas as funções da loja em Quijarro, vende, faz pagamentos, cuida do estoque de mercadorias, faz limpeza na loja entre outras atividades. A jornada de trabalho é de 10 horas diárias, em tom de desabafo, a comerciária diz que o marido participa mais da vida dos filhos do que ela. 
A senhora Illika relata que sua jornada diária é bem complexa e intensa, como trabalha com a venda de salgados levanta às três da madrugada para prepará-los, depois de passar a manhã toda oferecendo os salgados, retorna para Corumbá e começa a preparar "as quentinhas", que ao meio-dia leva para vender no Centro Comercial 12 de Octubre. Faz um intervalo e aguarda as comerciantes bolivianas realizarem as primeiras vendas do dia para terem dinheiro. Só depois disso a senhora Illika volta a circular para receber. A partir das 13 horas, faz suas cobranças e às 17 horas encerra seu expediente. Em dias alternados, a partir das 18 horas até as 22 horas faz faxina na casa de famílias bolivianas em Corumbá e em Arroyo. Justifica dizendo que realiza todas essas atividades diariamente porque um dia sem trabalho faz falta no sustento da família.

As mulheres que têm filhos e mantêm uma intensa jornada de trabalho se sentem culpadas por não estarem sempre presentes na vida dos filhos, muitas relatam que nunca conseguiram participar de eventos escolares, outras que mantêm os filhos em cidades distantes, privam-se de ir visitá-los por conta do trabalho.

\subsubsection{As trabalhadoras temporárias do comércio popular nas cidades bolivianas da fronteira}

A srta. Wayna ${ }^{118}$ porteña, dezenove anos, trabalha no comércio da fronteira há um ano. Há cerca de sete anos trabalhou como ambulante vendendo alimentos em Paradero, local onde fica a estação de trem de Puerto Suarez. Relatou que em Puerto Suarez não há muito trabalho para as mulheres, no geral trabalham no comércio vendendo arroz, macarrão e ganham menos do que em Arroyo Concepción, ou produzindo pão, empanado de queijo para vender para os turistas em Paradero, no entanto, demora mais para vender porque tem pouca circulação de pessoas.

Com o salário de mil e quatrocentos bolivianos consegue ajudar com as despesas da casa onde mora com a mãe e irmão em Puerto Suarez. Vai para casa apenas no domingo depois do meio-dia, durante a semana de segunda a sábado tem a função de abrir a loja às $04 \mathrm{~h} 30$ min da madrugada, ou mais tarde depende dos ônibus fretado que traz as sacoleiras, e ainda tem que vender rápido, porque há muita concorrência ao redor da loja.

$\overline{118 \text { Nome Aymara que significa jovem }}$ 
A loja tem duas funcionárias que atendem num espaço de vinte metros quadrados, no sábado é que vendem mais. Senhorita Wayna porteña relata que ao final do dia, ambas estão cansadas por percorrer toda a loja.

Para que consigam abrir a loja bem cedo, as funcionárias, como senhorita Wayna porteña, moram no mesmo prédio comercial que trabalham, na parte de cima tem quartos que a proprietária concede apenas para as mulheres. Este tipo de trabalho é denominado de "cama adentro". Tal forma de trabalho disponibiliza moradia e alimentação e não há desconto no salário referente a esses custos de hospedagem.

Durante a semana, quando as vendas estão mais fracas, senhorita Wayna porteña consegue fechar a loja às 18 horas e segue a pé para a escola, onde cursa a oitava série. Retorna da escola às $22 \mathrm{~h} 30 \mathrm{~min}$. Relatou que, à noite, em Arroyo, é muita violento, uma vez no trajeto de volta para o alojamento foi assaltada, por isso prefere morar em Puerto Suarez que é uma cidade mais tranquila.

A srta. Wayna cruceña tem 21 anos. Trabalha em Arroyo há um ano e mora em Puerto Suarez. Também é contratada pelo sistema de trabalho de "cama adentro", assim que aceitou o trabalho recebeu orientações sobre como vender uma roupa, porque nunca havia realizado vendas. Abre a loja às $5 \mathrm{~h} 30 \mathrm{~min}$ e fecha às $18 \mathrm{~h}$ de segunda a sábado, no domingo encerra a atividade ao meio-dia. Com o salário que ganha paga o curso de auxiliar contábil em Puerto Suarez. A srta. Wayna cruceña pretende voltar para Santa Cruz de la Sierra, porque lá a remuneração é melhor.

A srta. Wayna cochabambina tem 14 anos, trabalha no comércio de Arroyo há três meses. Veio de Cochabamba logo após o falecimento da mãe, mora com o pai que é caminhoneiro e trabalha com frete. Tem contrato de "cama a dentro" porque abre a loja às $05 \mathrm{~h} 30 \mathrm{~min}$ e fecha às $18 \mathrm{~h}$. Com o salário que recebe consegue pagar o curso noturno de estética para poder trabalhar em algum salão de beleza em Arroyo. Mas, não pretende viver na fronteira, deseja regressar para Cochabamba e ficar com a família que é toda de lá.

As mulheres denominadas "cama adentro" são geralmente aquelas trabalhadoras que buscam trabalho temporário, ou seja, não têm a pretensão de seguir na atividade do comércio de roupas. $\mathrm{Na}$ fronteira há pouca oportunidade para as mulheres sem provimento de capital, a grande maioria que trabalha no comércio de roupas estabelece 
contrato de trabalho mediante os vínculos com as redes familiares do comércio fronteiriço, tal relação social possibilita a essas trabalhadoras temporárias morarem no próprio estabelecimento. 


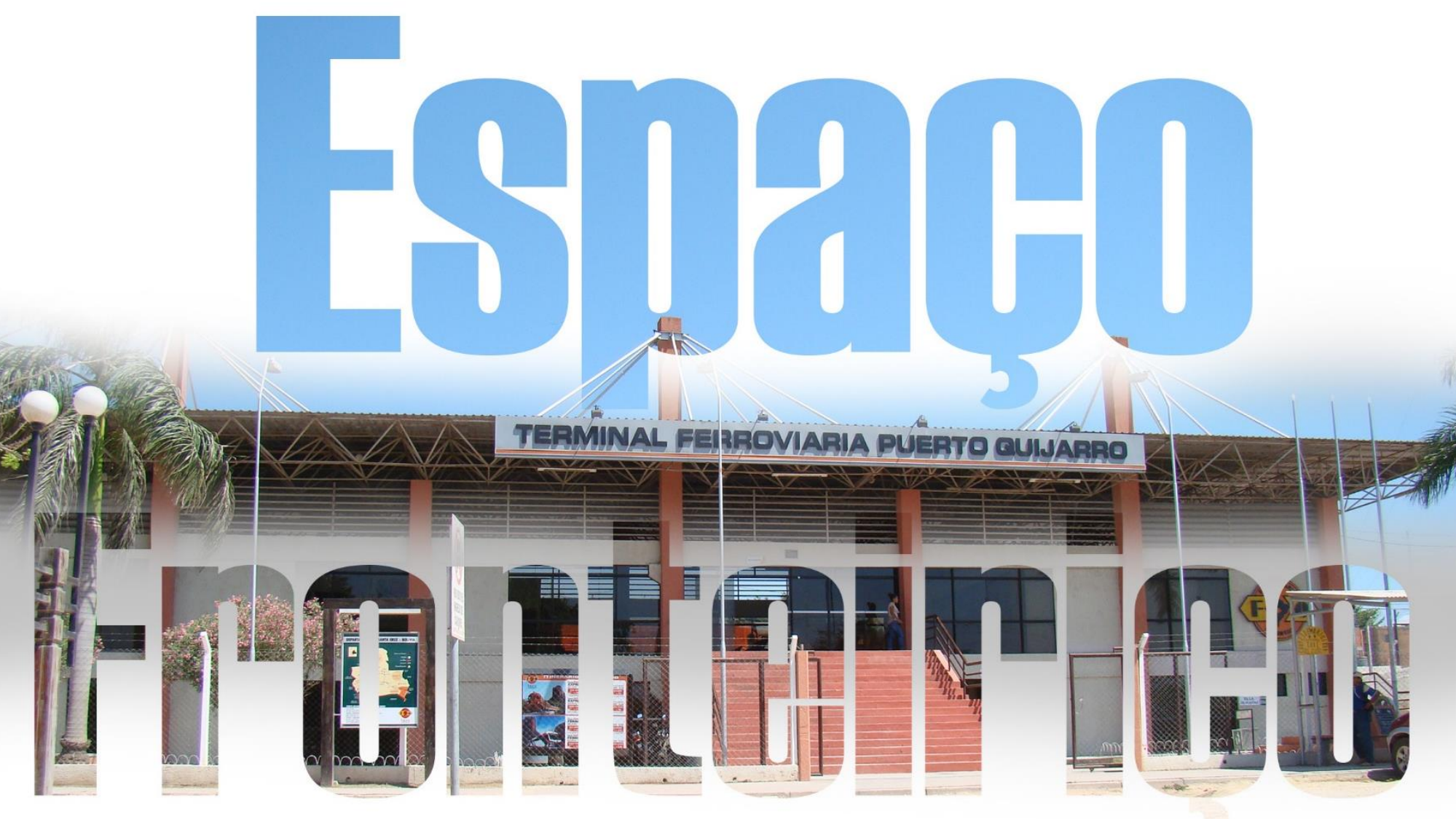

CAPÍTULO 4

OS ATORES COMERCIAIS E SUAS RELAÇÕES COM A

FRONTEIRA 
Neste capítulo é tratada da circulação nos territórios de fronteira a partir da dinâmica comercial do atacado e varejo entre as cidades-gêmeas e como essa dinâmica intensifica o comércio popular na fronteira, sobretudo organizado por comerciantes bolivianas.

Pretende-se neste estudo relacionar a geografia e o gênero a partir da natureza do espaço de fronteira tendo como ponto de partida os conceitos dos circuitos da economia urbana, por onde se inicia, em comum acordo com Silveira (2007):

\begin{abstract}
La fuerza del mercado concreto en el circuito inferior contrasta con el poder del mercado abstracto del circuito superior. Mientras que el fundamento del primero es el trabajo y sus productos -bienes y servicios producidos que buscan volver a la forma dinero para producir más bienes-, el fundamento del segundo es el dinero en estado puro, esto es, un dinero cuya rentabilidad se multiplica por el hecho de no abandonar tal forma. Los mercados concretos son territoriales, la arena de actores con existencias concretas en la ciudad, un dato constitucional para una nueva política (SILVEIRA, 2007, p.164). ${ }^{119}$
\end{abstract}

A teoria espacial dos circuitos da economia urbana de Milton Santos ilumina este estudo sobre a contribuição do trabalho feminino na produção do espaço transfronteiriço, porque revela as relações (in) visíveis dos vários usos do território com atributos femininos e, por conseguinte, possibilita revisitar temas como as desigualdades sociais e, principalmente, de gênero em países em desenvolvimento, como Brasil e Bolívia.

O sistema da economia urbana é composto por dois subsistemas, denominados de circuito superior e circuito inferior, que possibilita duas formas de consumo: uma de natureza qualitativa (produtos e serviços intensivos em tecnologia) e outra quantitativa (produtos e serviços oferecidos a varejo e com uso intensivo em mão de obra) e está dividido por categorias sociais, entre classes sociais abastadas e as menos favorecidas.

Em termos gerais, o conceito de cada circuito da economia urbana dos países subdesenvolvidos de Milton Santos (1979, p.33) é definido primeiramente pelo "conjunto das atividades realizadas em certo contexto" e segundo pelo "setor da população que se liga a ele essencialmente pela atividade e pelo consumo".

\footnotetext{
${ }^{119}$ Tradução: A força do mercado concreto do circuito inferior contrasta com o poder do mercado abstrato do circuito superior. Enquanto a base do primeiro é o trabalho e seus produtos - bens e serviços que retornam na forma de dinheiro para produzir mais bens -, a base do segundo é o dinheiro em estado puro, isto é, o dinheiro cuja rentabilidade se multiplica pelo fato de possuir liquidez. Os mercados concretos são territoriais, a arena de atores com ações concretas na cidade, uma informação constitucional para uma nova política.
} 
Para tanto, observa-se nessas cidades-gêmeas o impacto do comércio de exportação e importação de produtos de commodities e industrializados, os quais passam pela fronteira e criam oportunidades adversas, uma delas é o comércio de reexportação que dinamiza o circuito inferior duplicando o comércio organizado pelas mulheres fronteiriças.

Sobretudo, o governo boliviano vem aplicando o Código Tributário a todas as mercadorias que circulam naquele país, tal ação estabeleceu novas formas de concorrência para as empresas de exportação e importação das cidades-gêmeas de fronteira. No caso específico de Corumbá, foi constatado que o impacto dessas medidas fiscais do governo boliviano refletiu positivamente no comércio transfronteiriço, no sentido de que aumentou a exportação de produtos industrializados do Brasil para o mercado boliviano, principalmente, para Santa Cruz de la Sierra.

\subsection{As minoristas e as mayoristas do ramo de vestuário}

Pode-se dizer que o carro-chefe das famílias Aymaras ${ }^{120}$, que, atualmente, controlam o comércio atacadista de importação de roupas na Bolívia, é o mercado de roupas (americanas). Segundo dados de 2005, 93\%, das roupas usadas importadas entraram ilegalmente no país por Pisiga, procedentes da Zona Franca de Iquique, Chile foram destinados ao departamento de Oruro. De lá, seguiam para o Peru, onde feirantes levavam até a fronteira peruana de Desaguadero, E as melhores peças chegavam até as lojas da zona sul da cidade de La Paz (TASSI et al., 2013, p. 72; 107; 109 e 110).

Recentemente, o aumento de restrições e controle por parte do governo fez com que muitos importadores abrissem mão do mercado de roupas usadas e passassem a importar roupas novas diretamente da China, de marcas conhecidas. Essas roupas eram reproduzidas em Oruro e de lá ganhavam escala aumentando ainda mais o poder de distribuição desses grandes importadores sobre o território boliviano (TASSI et al., 2013, p. 110).

\footnotetext{
${ }^{120}$ Conforme a citação de Tassi et al (2013, p. 110) "O comércio de roupas usadas está controlado por grandes famílias importadoras, a maioria originária das regiões ocidentais de Oruro (Sabaya, Huachacalla, Escara), que mantem um vínculo forte com a região chilena de Tarapacá e um controle rígido da rota de importação".
} 
Conforme se observa na descrição de Tassi et al (2013), pode-se dizer que a entrada de produtos bolivianos e chineses no Brasil também se dá pela fronteira norte da Bolívia, via Guayaramerín que faz fronteira com o Estado de Rondônia e em Cobija com o Estado do Acre. Num breve destaque, estão relacionados os principais produtos distribuídos por todo o território boliviano:

(...) Sin embargo, la ropa china nueva - en su gran mayoría, medias, ropa interior, sábanas y frazadas - tiene uma distribución capilar a lo largo del país, incluyendo mercados rurales y fronteras. La ropa nacional, como camisas, poleras y pantalones - em su grand mayoría, confeccionada em Bolivia, pero com materiales foráneos -, tiene un muy vasto radio de distribución, habiendo ganado mercado en las fronteras y en las regiones alejadas del Norte (TASSI et al, 2013, p.110). 


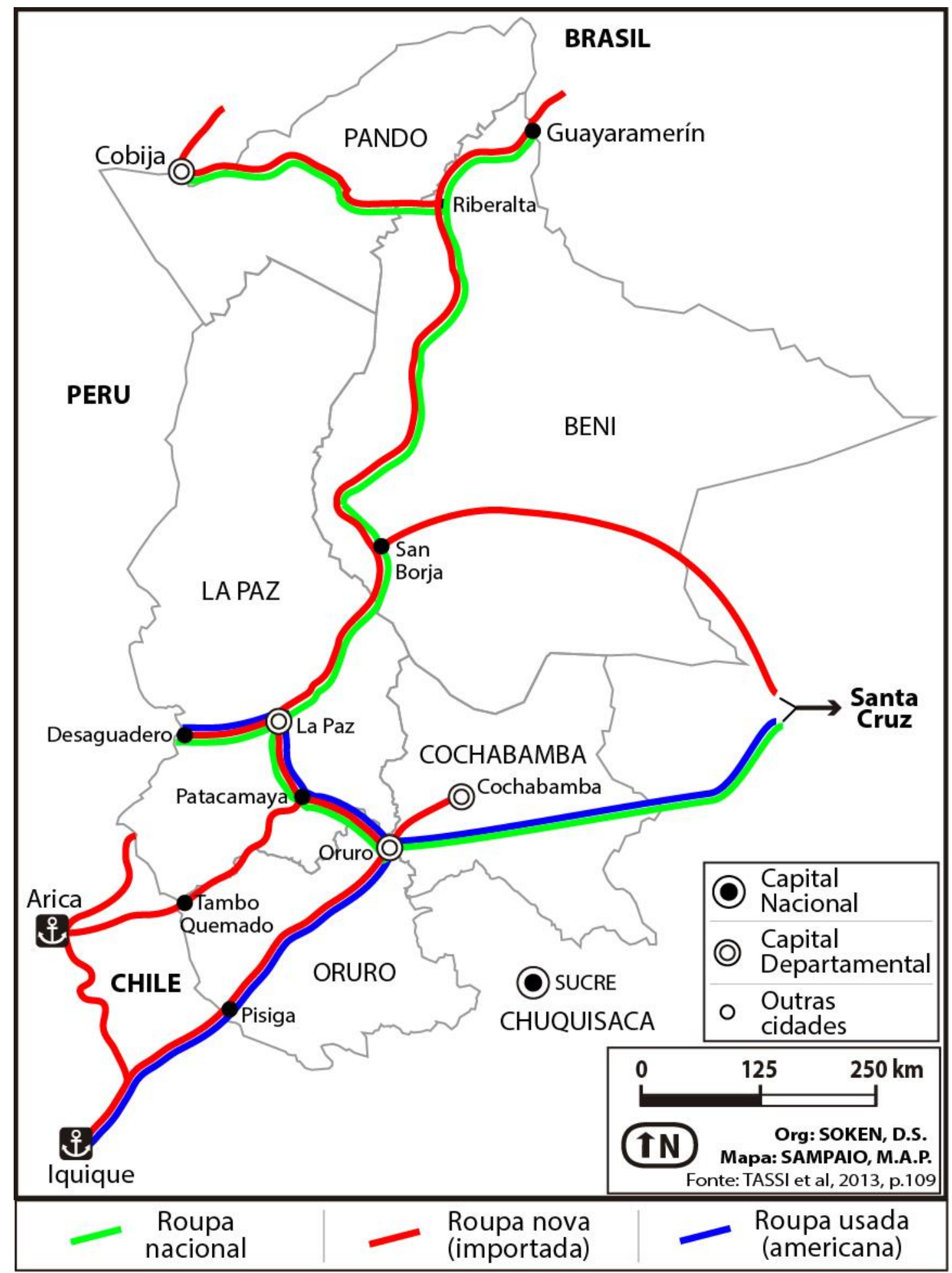

FIGURA 10 - Fluxo do comércio de roupas e calçados da Bolívia

Fonte: TASSI et al, 2013, p.109

Elaboração: SAMPAIO, M.A.P.

Considerando os relatos das comerciantes varejistas da fronteira, verifica-se que o comércio atacadista de roupas se intensificou a partir do ano de 2007, conforme revelou 
Atipaj. Depois que as mayoristas ${ }^{121}$ começaram a oferecer mercadorias mais baratas na fronteira, suas viagens até Santa Cruz de la Sierra diminuíram.

As mulheres que trabalham no comércio de atacado são originárias de várias localidades da Bolívia, como Oruro, Potosí, Cochabamba, La Paz e Santa Cruz de la Sierra, fazem importações de roupas direto da China. Além de trazerem aquelas roupas de confecção nacional, trazem também outras provenientes do Chile e Peru, importadas dos Estados Unidos e do Panamá.

As mayoristas chegam à fronteira todas as quintas-feiras e se hospedam em alojamentos que servem também de depósitos, lugar onde as comerciantes varejistas, as minoristas $^{122}$, adquirem novos produtos e também fazem novas encomendas. Podem escolher os produtos por dúzia ou caixa, dependendo do volume conseguem pagar com prazos mais extensos. Além disso, a sra. Atipaj observa que é mais seguro adquirir mercadorias das mayoristas porque caso recebam mercadorias com defeitos tem a garantia de troca, com exceção dos produtos importados do Chile que não conseguem substituição.

As minoristas compram por semana a média de dez a vinte dúzias de roupas, e pagam em parcelas semanais ou quinzenais. Constatou-se que os dias de recebimento das mayoristas é no sábado, quando o movimento é maior na fronteira, e quando as principais clientes, as sacoleiras, fazem suas compras à vista ${ }^{123} \mathrm{e}$ em grande quantidade.

O pagamento às mayoristas está estabelecido conforme as estações do ano, por exemplo, as roupas de verão são adquiridas antecipadamente entre os meses de setembro e outubro, cujos pagamentos podem ser parcelados. Verificou-se que o volume negociado por estação chega a mais de dez mil dólares ${ }^{124}$ por "casseta".

Observa-se que existem várias formas de realizar o pagamento às mayoristas, essas elegem as moedas brasileira, boliviana e americana como opções de recebimento, que podem variar conforme a forma de financiamento. Para os financiamentos de mais de três meses, estabelece-se o pagamento em moeda americana (dólar). Já nas formas de

\footnotetext{
121 Termo em espanhol que significa atacadista.

122 Termo em espanhol que significa varejista.

${ }^{123}$ Constatou-se que a média de gasto das sacoleiras por viagem ficava entre mil a cinco mil reais.

${ }^{124}$ Entre os anos de 2007 a 2012 o volume negociado por estação em média era de sessenta mil dólares por casseta.
} 
pagamento semanais ou quinzenais o recebimento ocorre com moeda boliviana ou brasileira. Percebe-se que a maioria faz pagamento com moeda brasileira, uma vez que ela tem maior facilidade de circulação no mercado da fronteira, o que permite compreender que no momento as compras estão sendo realizadas em menores quantidades.

Nos últimos anos houve uma queda significativa das vendas, o que fez algumas mulheres minoristas que possuem mais de uma casseta no Centro Comercial 12 de Octubre alugar esses espaços para comerciantes brasileiros ao valor médio de trezentos e cinquenta dólares. Já outros estão investindo na construção civil ou voltaram para Santa Cruz de la Sierra. Segundo, o presidente da Associação do Centro Comercial 12 de Octubre, a concorrência ao redor tem aumentado e consequentemente a margem de lucro dos lojistas tem caído. Além, disso, o governo intensificou a fiscalização nas estradas e cobrando os tributos sobre as mercadorias transportadas, o que, de certa forma, contribui para a alta do preço de atacado para os lojistas da fronteira.

Para tentar driblar a concorrência sra. Atipaj estabeleceu alguns laços de confiança com algumas sacoleiras, que ao determinar a quantidade mínima de dez peças facilita o pagamento e permite que a cliente (sacoleira) pague a metade na próxima semana. A comerciante boliviana faz o controle em uma caderneta onde aponta o nome da cliente, telefones, o dia de retorno e o valor negociado. Inclusive a sra. Atipaj encontrou uma solução para aquelas sacoleiras que sofrem com as apreensões das mercadorias, ela oferece crédito pessoal para que adquiram novamente a mercadoria, desta forma, a senhora Atipaj diminui o custo (risco do negócio) das clientes (sacoleiras) no comércio popular na fronteira.

\subsection{O circuito comercial transfronteiriço}

A parte oriental da Bolívia recebeu entre as décadas de 1960 a 1970 investimentos nos setores do agronegócio e na construção de rodovias com destaque a Carretera Santa Cruz de la Sierra-Cochabamba, com a extensão de $325 \mathrm{~km}$ possibilitou o processo de colonização interna com a migração da população do ocidente para as tierras bajas da Bolívia. Tais investimentos alavancaram a produção de petróleo e alimentos do 
departamento de Santa Cruz, o que contribuiu para aumentar a participação no PIB nacional (SANDOVAL ARENAS, 2013, p.44).

Atualmente, o departamento de Santa Cruz participa com 27,28\% do PIB nacional, com destaque para as atividades setoriais, tais como: agricultura, silvicultura, caça e pesca as quais perfazem $41,58 \%$; as indústrias manufatureiras com 37,03\% e o setor de eletricidade, gás e água representando 35,43\% do PIB setorial em nível nacional. Cabe mencionar a produção de gás natural que representa $18,65 \%$ da produção nacional, enquanto a de petróleo representa com 11,29\% da produção nacional (INE/2010).

Com base na FIGURA 11 "Valor Bruto da Produção (em moeda Bs\$) por atividade segundo departamento, ano de 2010, Bolívia" podemos afirmar que o departamento de Santa Cruz é o centro de distribuição de mercadorias do país, contribuiu com $71,37 \%$ na atividade de comércio varejista e atacadista e também participou com 46,29\% nas atividades industriais e 49,67\% de serviços. 


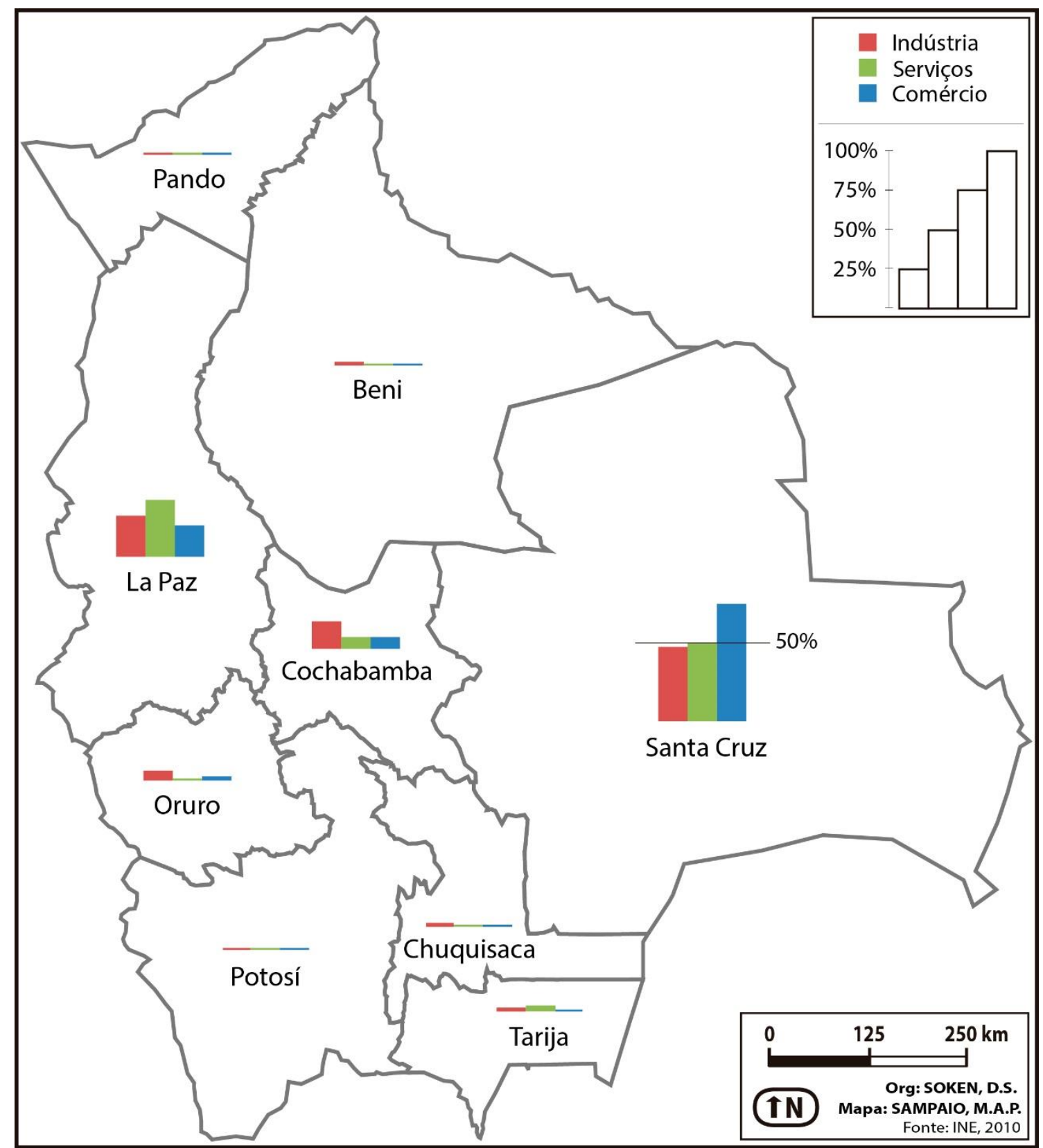

FIGURA 11 - Valor Bruto da Produção (em moeda Bs\$) por atividade (\%) segundo departamento, ano de 2010, Bolívia.

Fonte: INE/Estadísticas Estruturales da la Industria manufacturera, Comercio y Servicios - 2010

Organização: SOKEN, D.S.

Elaboração: SAMPAIO, M.A.P.

Em 2014, 30\% das exportações bolivianas foram para o Brasil. E considerando a proximidade com o Brasil, o departamento de Santa Cruz participa com 24\% das exportações para aquele país. No entanto, outros destinos também se destacam, como a Colômbia com 19\%, Argentina e Peru com 13\% cada e com a participação significativa de 3\% cada um se destacam a Venezuela e o Equador (INE/2010). 
Com base nos dados de 2014, verifica-se que a pauta de exportação do departamento de Santa Cruz para o Brasil e Argentina é predominantemente de gás natural, $64 \%$ e $36 \%$ respectivamente. A produção de soja e derivados é exportada para Colômbia que perfaz 55\%, Peru com 26\%, Equador (8\%), Venezuela (7\%) e Chile (3\%) (INE, 2014).

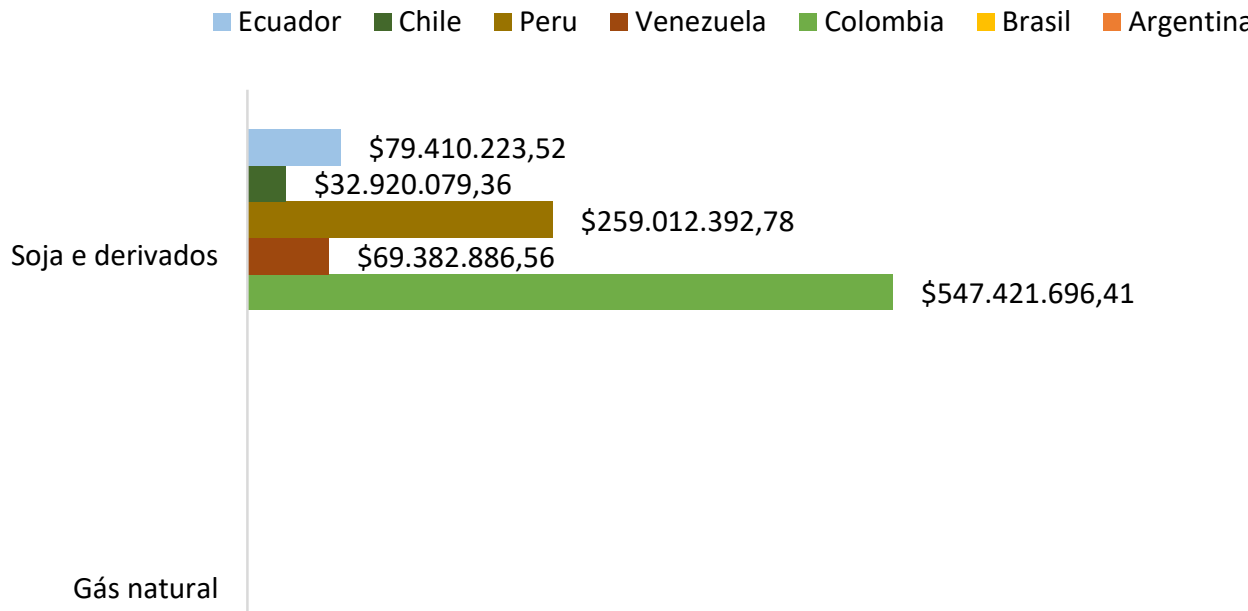

$\$ 426.292 .418,71$

$\$ 765.734 .080,89$

GRÁFICO 35 - Principais produtos de exportação do departamento de Santa Cruz, segundo principais países de destino, valores em moeda americana (US\$ FOB), ano de 2014.

Fonte: INE/Bolívia

Elaboração: SOKEN, D., 2015

Considerando a proximidade do município de Corumbá com o departamento de Santa Cruz, verifica-se que o comércio de exportação do município tem tido uma participação significativa no saldo de exportações para a Bolívia. A partir do ano de 2009, constatou-se que a participação de Corumbá nas exportações para a Bolívia saltou de 2,58\% no ano de 2008 para 29,25\% em 2009, que totalizou o valor de US\$ 54.685.382,00. Os melhores resultados do comércio de exportação aconteceram nos anos de 2010 e 2011 que alcançaram valores de US\$ 78.689.198,00 e US\$87.282.109,00 respectivamente (MDIC, 2014). 


\begin{tabular}{c|cc|cc|c}
\hline Ano & \multicolumn{2}{|c|}{$\begin{array}{c}\text { Total do município } \\
\text { (US\$ F.O.B.) }\end{array}$} & \multicolumn{2}{c|}{$\begin{array}{c}\text { Destinado à Bolívia } \\
\text { (US\$ F.O.B.) }\end{array}$} & $\begin{array}{c}\text { Participação no município } \\
\text { (\%) }\end{array}$ \\
\hline 2005 & $\$$ & $82.333 .760,00$ & $\$$ & $10.203 .665,00$ & 12,39 \\
\hline 2006 & $\$$ & $115.725 .388,00$ & $\$$ & $4.520 .985,00$ & 3,91 \\
\hline 2007 & $\$$ & $96.746 .503,00$ & $\$$ & $8.313 .611,00$ & 8,59 \\
\hline 2008 & $\$$ & $449.936 .241,00$ & $\$$ & $11.586 .717,00$ & 2,58 \\
\hline 2009 & $\$$ & $186.946 .847,00$ & $\$$ & $54.685 .382,00$ & 29,25 \\
\hline 2010 & $\$$ & $376.382 .660,00$ & $\$$ & $78.689 .198,00$ & 20,91 \\
\hline 2011 & $\$$ & $687.382 .730,00$ & $\$$ & $87.282 .109,00$ & 12,7 \\
\hline 2012 & $\$$ & $400.208 .386,00$ & $\$$ & $51.445 .847,00$ & 12,85 \\
\hline 2013 & $\$$ & $501.574 .203,00$ & $\$$ & $49.794 .898,00$ & 9,93 \\
\hline 2014 & $\$$ & $579.111 .252,00$ & $\$$ & $57.897 .214,00$ & 10
\end{tabular}

TABELA 16 - Saldos de exportação do município de Corumbá com destino à Bolívia, segundo valores em moeda americana (F.O.B.), por ano.

Fonte: Ministério do Desenvolvimento, Indústria e Comércio Exterior-MDIC/Brasil

Elaboração: SOKEN, D.

Conforme a pesquisa de campo, pode-se dizer que o setor de alimentos e bebidas foi o maior responsável pelo aumento desse saldo comercial ${ }^{125}$. De acordo com sr. Fernando, comerciante de exportação ${ }^{126}$ com sede na cidade de Corumbá, as vendas de alimentos para Santa Cruz de la Sierra cresceram a partir de 2008, em razão da tributação $^{127}$ do governo boliviano sobre toda mercadoria que entrasse na Bolívia, medida que resultou em redução da concorrência. Essa ação governamental tem inviabilizado o trabalho dos comerciantes de importados que não atenderam às normas estipuladas pelo governo. Inclusive, a aplicação do código tributário na Bolívia tem repercutido na fronteira de Corumbá com as cidades de Puerto Quijarro e Puerto Suarez. Antes, as mercadorias de exportação seguiam para Santa Cruz de la Sierra e retornavam para a fronteira sem recolhimento de impostos bolivianos.

A partir da observação do sr. Fernando sobre a atividade de exportação para a Bolívia, é possível considerar que aqueles exportadores que atenderam às especificações tributárias e fizeram as adequações exigidas, as exportações estão inseridas no mercado boliviano com maior competitividade. Há cerca de dez anos (ano de 2005) se estabeleceu

\footnotetext{
${ }^{125}$ Ressalta-se que o minério de ferro tem como destino a Argentina e representa 80,98\% das exportações do município de Corumbá, no ano de 2014 somou o valor de US\$ 468.978.261 (valor em FOB).

${ }^{126}$ Os produtos com destino à exportação no Brasil recebem alguns benefícios fiscais, como isenções de impostos e taxas, são eles: Impostos sobre Produtos Industrializados (IPI);Impostos sobre Circulação de Mercadorias (ICMS);Programa de Integração Social (PIS/PASEP);Contribuição para Financiamento da Seguridade Social (COFINS)

${ }^{127}$ A lei n. 3446 de 21 de julho de 2006, trata-se dos impostos sobre transações financeiras; Lei 2492 de 02 de agosto de 2003 que estabelece o Código Tributário boliviano atualizado em 30 de setembro de 2014.
} 
no mercado de Santa Cruz de la Sierra um depósito de produtos de exportação e importação que atua também em Cochabamba e pretende se instalar em Trinidad, capital do departamento de Beni.

Segundo sr. Fernando, considera-se que o mercado de importação de Santa Cruz de la Sierra determina o nível de preços do setor de alimentos na Bolívia, pois recebe mercadorias de todas as fronteiras. A fronteira da Argentina e do Chile são os maiores concorrentes da fronteira brasileira em produtos alimentícios.

De acordo com os dados do Instituto Nacional de Estadística - INE/Bolívia, constata-se que as principais entradas de produtos alimentícios e bebidas importadas para o departamento de Santa Cruz de la Sierra são provenientes de Corumbá/Brasil seguem via Puerto Suarez. Existe ainda entrada pelo porto de Arica/Chile que chega até a fronteira com a Bolívia por Tambo Quemado no departamento de Oruro e pela fronteira com a Argentina, a cidade boliviana de Yacuíba.

Conforme se demonstra no GRÁFICO 36 existe uma alternância no volume negociado de mercadorias importadas entre as cidades de fronteira. Quando o volume negociado por Corumbá/Puerto Suarez está crescente, verifica-se que o volume da cidade de Yacuíba está decrescente. Desta forma, pode-se dizer que o mercado concorrente da fronteira Corumbá/Puerto Suarez é a cidade de Yacuíba, na fronteira com a Argentina. Cabe observar também que o volume negociado em todas as cidades fronteiriças teve um crescimento a partir de 2010, fato que pode estar relacionado com a padronização dos produtos importados e com a tributação do governo boliviano no mercado interno. 


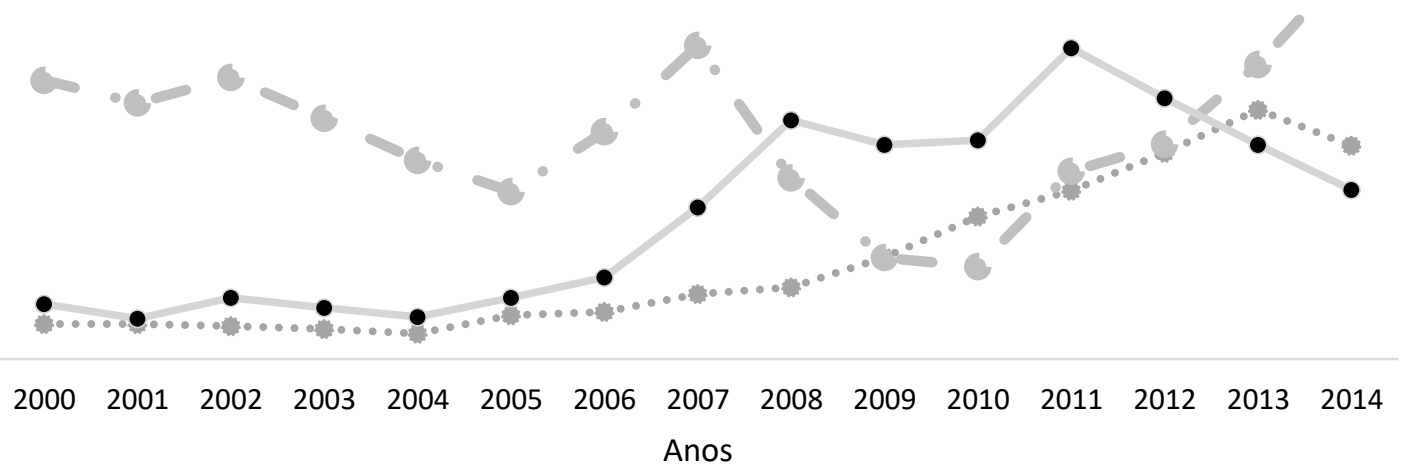

GRÁFICO 36 - Importação de Alimentos e Bebidas do Departamento de Santa Cruz, segundo principais locais de entrada, por ano de 2000 a 2014, valores em moeda americana (US\$ FOB).

Fonte: INE/Bolívia

Elaboração: SOKEN, D.

Nota-se que as mercadorias provenientes da fronteira com o Chile são complementares, ou seja, os produtos não são similares, conforme verifica-se no gráfico existe um crescimento contínuo no volume importado, portanto, pode-se dizer que o mercado de pescado é exclusividade chilena.

No entanto, percebe-se que outros produtos como por exemplo o óleo de soja, o volume de venda desse produto depende da competitividade do setor de agronegócios e principalmente do mercado de câmbio de cada fronteira. Desta forma, afirmou sr. Fernando que a melhor estratégia é ter negócios nos dois lados da fronteira, porque pode se apropriar das variações do mercado de câmbio e assim obter ganhos em alternância.

Com base nessa lógica dos negócios da fronteira, ressaltou sr. Fernando que as estratégias de competição na cidade de Corumbá se dá mediante parâmetros internacionais, ou seja, a dimensão do mercado concorrencial é entre países, sendo assim, mesmo considerando a população de Corumbá de cem mil habitantes, além dos trinta mil do lado boliviano, pode-se dizer que a retomada do comércio atacadista e a entrada de supermercado varejista de bandeira na cidade de Corumbá são, todavia, duas situações 
desfavoráveis, porque a proximidade de Corumbá com as cidades bolivianas está cada dia se intensificando ${ }^{128}$.

Por ora, observa-se uma forte tendência de queda do comércio varejista na cidade de Corumbá, conforme demonstra o gráfico abaixo entre os anos de 1988 a 1990 o número de estabelecimentos varejista era superior a mil, em contrapartida, a partir dos anos de 1991 até 2001 houve uma queda significativa no número de estabelecimentos, de 799 caiu para 148 estabelecimentos varejista na cidade.

Percebe-se que essa queda foi superada pelo crescimento dos estabelecimentos atacadistas, que saltaram de 210 estabelecimentos no ano de 1995 para 731 no ano de 2001, atingindo a quantidade de 843 estabelecimentos atacadistas no ano de 2003. Entre os anos de 2004 a 2008 o número de estabelecimentos sofreu uma queda anual de aproximadamente 50 estabelecimentos, no entanto entre os anos de 2009 a 2012 houve uma ascensão por ano de cerca de 100 estabelecimentos, somando um total de 976 estabelecimentos de atacado na cidade em 2012.

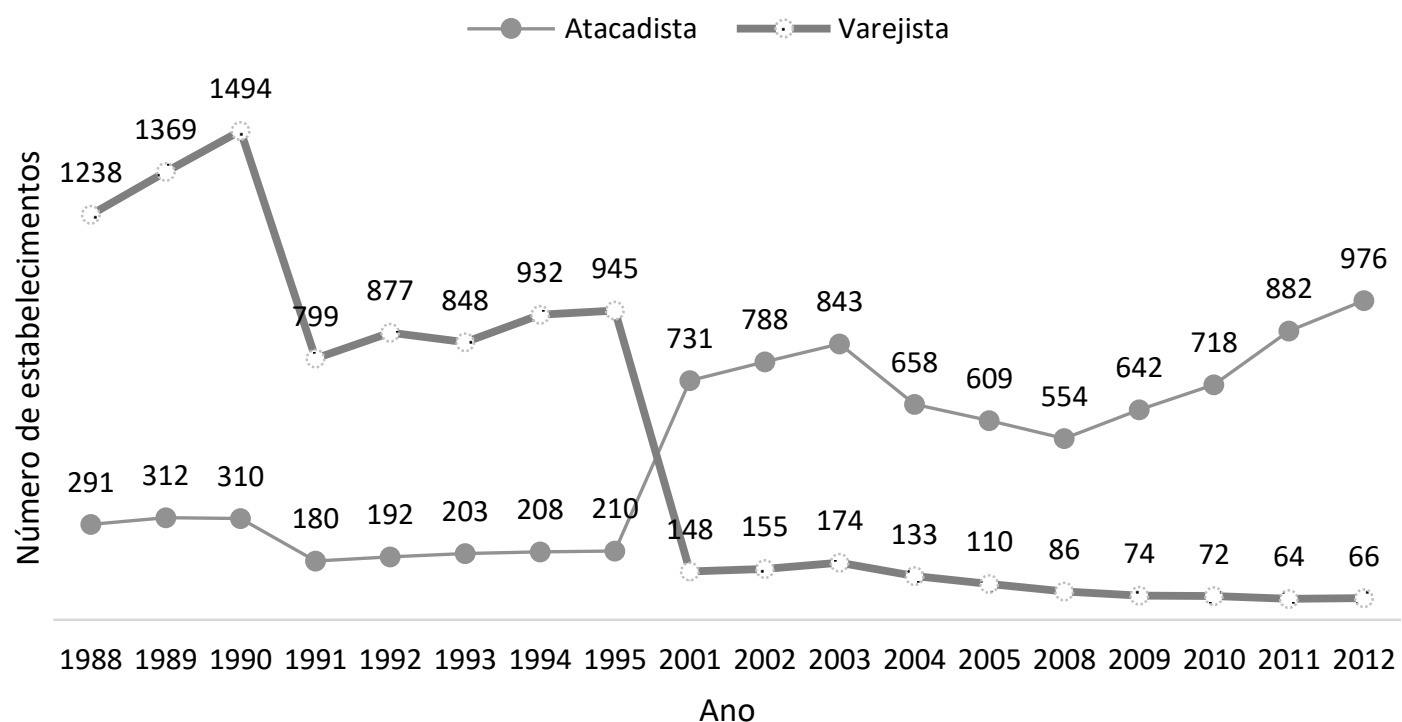

GRÁFICO 37 - Número de estabelecimentos comerciais do ramo varejista e atacadista da cidade de Corumbá, Mato Grosso do Sul, segundo os anos de 1988 a 1995 e 2001 a 2012.

Fonte: Secretaria da Fazenda apud Oliveira, T.C.M, 1998; SEPLANCT/MS, Indicadores básicos municipais, 2006 e SEMAC/IBGE.

Elaboração: SOKEN, D.

\footnotetext{
${ }^{128}$ De acordo com as considerações de Oliveira (1998), Corumbá “assume assim, um papel diferente na sua posição geográfica: não mais é um centro importador; não mais é um centro produtor; e ergueu formas de ser um centro intermediador-exportador" (OLIVEIRA,1998, p. 116).
} 
Pode-se observar que o período de auge do comércio varejista de Corumbá se deu quando uma leva de comerciantes de importação da cidade de Santa Cruz de la Sierra se deslocou até a fronteira em busca de produtos brasileiros, além disso, conforme destacou Oliveira (1998):

Há a partir de 1984, uma recuperação da economia mundial puxada pelo déficit fiscal e comercial americano. O crescimento da demanda norte-americana, movimentada em consequência de um gigantesco programa de investimentos por volta de U\$ 2 trilhões no setor militar (programa guerra das estrelas), recuperou parte significativa da economia americana, europeia e japonesa dando um novo ritmo às relações comerciais entre todas as nações. (...) As economias retardatárias passaram a participar com intensidade do período de reordenamento das relações comerciais mundiais. Verifica-se, nesse período, uma "quebra" da seletividade no comércio internacional: não houve restrição à participação de nenhum país. Possibilitando que países de economias atrasadas, desmotivadas e desindustrializadas também participassem dessa fluidez mercadológica inclusive a Bolívia. (...) Quebrando as amarras das condições para exportar, tanto o mercado mundial quanto o governo brasileiro disponibilizavam volumes cada vez maiores de produtos industrializados a serem exportados por pequenas e até minúsculas empresas exportadoras - fato anteriormente impossível. Em outras palavras, foram dadas as condições para detonar um estreitamento de relações comerciais entre o Brasil e a Bolívia, passando por Corumbá (OLIVEIRA, 1998, p. 67 a 69)

Para tanto, observa-se que a partir do controle de entrada e saída de mercadoria pelo sistema unificado ${ }^{129}$ entre a empresa de exportação e importação e os órgãos de controle $^{130}$ federal brasileiro e boliviano certamente serão estabelecidos novas redes de negócios transfronteiriços, por meio das quais os atores atuais que operam o sistema de circulação e distribuição de mercadorias de commodities e industrializados encontram diversas oportunidades para usar o território fronteiriço, uma vez que as redes familiares que também operam o sistema de distribuição na Bolívia estão buscando outras rotas de negócios ${ }^{131}$.

No entanto, com base na pesquisa verificou-se que há um grupo de mulheres atacadistas, cerca de cinco bolivianas, que atua nas fronteiras em busca de melhores preços e alguns casos, de produtos alimentícios de marcas conhecidas. Essas mulheres

\footnotetext{
${ }^{129}$ O Mercosul adota desde janeiro de 1995 o Sistema Harmonizado que é um método internacional de classificação de mercadorias, baseado em uma estrutura de códigos e respectivas descrições.

${ }^{130}$ Desde de $1^{\circ}$ de março de 2012 funciona no Porto Seco da Agesa de Corumbá o acordo bilateral entre a Aduana boliviana de Puerto Suarez com a Receita Federal de Corumbá que estabelece uma Área de Controle Integrado onde operam conjuntamente os órgãos aduaneiros fronteiriços (Diário ON line, 2012). ${ }^{131}$ A variação do câmbio entre a moeda brasileira em relação a moeda boliviana altera o comércio de alimentos perecíveis e industrializados de La Paz até Cobija cidade de fronteira com Acre, a margem de lucro dos transportadores depende da variação das moedas (TASSI et al, 2013, p. 171). Isso impacta também no fornecimento de produtos que são oferecidos pelos feirantes bolivianos que trabalham na cidade de Corumbá, constata-se que muitos produtos são de procedência boliviana e entram pela fronteira norte do Brasil, onde abastecem as cidades de fronteira do Estado do Acre e Rondônia.
} 
operam o comércio de importação de mercadorias com auxílio de comerciantes de exportação da cidade de Corumbá e das cambistas, mulheres do mercado de moeda as chamadas "as doleiras" da fronteira. Isso configura uma determinada funcionalidade dessa fronteira, onde os agentes da circulação agem a favor do processo de acumulação nos dois lados da fronteira.

Essas comerciantes realizam grandes negócios nas fronteiras bolivianas e têm contato com pelo menos um agente do circuito de distribuição em cada localidade que auxilia no levantamento de preços e propõe melhores momentos para realizar as transações. Geralmente, são contatos formalizados via e-mail ou telefone. Até o momento, não foi possível marcar entrevistas com esse grupo de mulheres atacadistas, porque não estabelecem contato pessoal, elas mantêm contato com intermediários, seja do lado brasileiro ou boliviano. Nota-se que por toda a fronteira são conhecidas, todos sabem quem são, mas nunca sabem dizer quando chegam e onde ficam.

Por sua vez, o comércio atacadista da cidade de Corumbá tem como atributo operar no mercado de Campo Grande para os comerciantes de Puerto Quijarro, onde são adquiridos produtos como de óleo de soja, bebidas, carne de frango, etc, no geral são produtos de oferta das grandes redes de atacado da capital sul-mato-grossense. De acordo com os relatos daqueles que trabalham com o comércio de exportação, o comerciante boliviano é um ótimo comprador, sempre adquire mercadorias em quantidades bem expressivas, e, sobretudo, realiza pagamento à vista, em reais ou dólares.

Desta forma, com base nas informações coletadas pela pesquisa, constatou-se que a "Empresa Atacado Fernandes de Gênero Alimentício de Exportação e Importação Ltda" para se estabelecer no mercado boliviano, especificamente em Santa Cruz de la Sierra, tratou de atender à todas as exigências de exportação e importação do governo boliviano, por exemplo, houve determinação do tamanho e tipo da embalagem dos produtos, além de acréscimo de vitaminas $\mathrm{A}^{132}$ nos produtos de óleo de soja, entre outras. Teve que realizar os pedidos às indústrias brasileiras de acordo com as normas de padronização do produto, isso possibilitou negociar volumes mais significativos, uma vez que a indústria se ajustou para atender esse mercado específico. Além disso, foi possível constatar que

\footnotetext{
132 O decreto Supremo n. 28094 de 22 de abril de 2005 estabelece a Legislação e Regulamento do azeite vegetal comestível fortificado com vitamina A. Tal legislação norteia o Programa Nacional de Foritificação de Alimentos de 2009.
} 
essas medidas de controle do governo boliviano da circulação de mercadorias elevassem os níveis de arrecadação tributária boliviana.

Considerando a atuação do poder público sobre o contrabando, acredita sr. Fernando, que atualmente em Santa Cruz de la Sierra essa prática tem sofrido reduções, pois todas as empresas que antes importavam de todos os lugares tiveram que se ajustar a essa nova padronização exigida pelo governo. Conforme sua observação, muitas empresas de importação deixaram o mercado de Santa Cruz de la Sierra e foram para outras localidades.

\subsection{As mulheres do circuito inferior ${ }^{133}$ das cidades-gêmeas de fronteira}

Com base nos dados do Instituto Brasileiro de Geografia e Estatística IBGE/Brasil e RAIS do ano de 2013, verificou-se que a participação da mulher no mercado de trabalho em Corumbá está concentrada em pelo menos três segmentos da economia da cidade, são eles: o comércio com 39\%; os serviços com $42 \%$ e a administração pública com 59\%. Já as atividades que são industriais, agropecuária, extrativista e construção civil são atribuições masculinas, eles também estão ocupando áreas de maior participação feminina, por exemplo, na atividade comercial os homens já representam $61 \%$ e nos serviços $58 \%$.

Percebe-se que a atuação masculina no comércio ocorre em estabelecimentos onde as vendas dos produtos são comissionadas e os produtos comercializados pertencem ao circuito superior, caso das concessionárias de carros, motos e barcos, entre outros. Enquanto que, a maioria das mulheres que atua no comércio está em setores de consumo popular, como os supermercados, vestuário, calçados, móveis, entre outros, onde as vendas são de baixo valor e a maioria é assalariada.

\footnotetext{
${ }^{133} \mathrm{O}$ circuito inferior na economia urbana constitui um mecanismo permanente de integração que oferece um número máximo de oportunidades de emprego com um volume mínimo de capital. Esse circuito corresponde exatamente às condições gerais de emprego e disponibilidade de dinheiro, assim como às necessidades de consumo de uma importante fração da população (SANTOS, 2009, p.67).
} 
Desta forma, verificou-se que o rendimento médio dos homens está predominantemente acima da média dos setores, salvo nos setores de extrativa mineral e a construção civil que perdem entre dez e cinco reais, respectivamente. Já a remuneração média das mulheres está significativamente abaixo da média dos setores, com exceção da construção civil que recebe o valor de cento e vinte e cinco reais acima da média e também está acima da média a extrativa mineral, setor onde o salário tem valor superior de oitenta e nove reais.

Mas, foi o setor da indústria de transformação que registrou a maior perda de rendimento feminino. Cerca de $21 \%$ das mulheres que atuavam nesse setor recebiam em termos de valores monetários quinhentos e dezessete reais menos do que a média do setor. Para os demais setores, a perda de remuneração foi significativa, em torno de trezentos reais. Com ressalvas para o comércio que teve a menor perda, de oitenta e cinco reais.

\begin{tabular}{|c|c|c|c|c|}
\hline \multirow[t]{2}{*}{ Setores } & $\begin{array}{l}\text { Variação da } \\
\text { remuneração } \\
\text { média por sexo }\end{array}$ & $\begin{array}{l}\text { Participação } \\
\text { por sexo no } \\
\text { setor }\end{array}$ & $\begin{array}{c}\text { Variação da } \\
\text { remuneração } \\
\text { média por sexo }\end{array}$ & $\begin{array}{l}\text { Participação por } \\
\text { sexo no setor }\end{array}$ \\
\hline & Masculino & $\%$ & Feminino & $\%$ \\
\hline EXTRATIVA MINERAL & $(-R \$ 10)$ & $90 \%$ & $\mathrm{R} \$ 89$ & $10 \%$ \\
\hline $\begin{array}{l}\text { INDÚSTRIA DE } \\
\text { TRANSFORMAÇÃO }\end{array}$ & $\mathrm{R} \$ 135$ & $79 \%$ & $(-\mathrm{R} \$ 517)$ & $21 \%$ \\
\hline SERVIÇOS INDUSTRIAIS & $\mathrm{R} \$ 49$ & $85 \%$ & $(-R \$ 296)$ & $15 \%$ \\
\hline CONSTRUÇÃO CIVIL & $(-R \$ 5)$ & $96 \%$ & $\mathrm{R} \$ 125$ & $4 \%$ \\
\hline COMÉRCIO & $\mathrm{R} \$ 54$ & $61 \%$ & $(-R \$ 85)$ & $39 \%$ \\
\hline SERVICOS & $\mathrm{R} \$ 177$ & $58 \%$ & $(-R \$ 243)$ & $42 \%$ \\
\hline $\begin{array}{l}\text { ADMINISTRAÇÃO } \\
\text { PÚBLICA }\end{array}$ & $\mathrm{R} \$ 307$ & $41 \%$ & $(-R \$ 216)$ & $59 \%$ \\
\hline AGROPECUÁRIA & $\mathrm{R} \$ 43$ & $85 \%$ & $(-R \$ 232)$ & $15 \%$ \\
\hline
\end{tabular}

TABELA 18 - Comparativo do setor referente a diferença da remuneração média segundo sexo (valores em R\$), distribuído conforme a participação do pessoal por setor em porcentagem, ano de 2013.

Fonte: IBGE/RAIS/Secretaria de Indústria e Comércio de Corumbá, 2013

Elaboração: SOKEN, D.

Considerando a baixa remuneração das mulheres no circuito espacial produtivo ${ }^{134}$ da cidade de Corumbá, bem como, a restrita oferta de empregos, constata-se então, que as alternativas encontradas por outras mulheres foi se apropriar do excedente de mercadorias que circulavam pelas cidades-gêmeas fronteiriças.

\footnotetext{
${ }^{134}$ Desta forma, com base na pesquisa de campo, é possível dizer que o comércio varejista do circuito inferior das cidades de fronteira é intensivo em uso de mão de obra de mulheres migrantes e a característica elementar diz respeito à relação de trabalho, onde prevalece o regime de trabalho familiar. E até o momento, foi registrado a presença em massa de mulheres no comércio de alimentos industrializados e vestuário feminino de ambas as cidades.
} 
Ao longo das décadas de 1980 a 1990 existia uma quantidade significativa de produtos de exportação que retornavam para a fronteira, essa operação era feita pelos comerciantes atacadistas e varejistas existentes nas duas localidades da fronteira. Uma vez que não incidiam impostos sobre a mercadoria trazidas das diversas fronteiras da Bolívia, bem como, havia também interesse por parte do governo brasileiro de estimular esse tipo de comércio internacional, tal prática comercial transformou as cidades-gêmeas em locais de transbordo de mercadorias.

Os produtos de exportação eram nacionalizados na faixa de fronteira, no caso dos produtos exportados para Santa Cruz de La Sierra era realizado um transbordo da mercadoria em Puerto Quijarro onde era realizada a nacionalização e o transporte por empresas bolivianas.

Foi a partir do comércio "formiguinha" do lado brasileiro que as mulheres bolivianas conseguiram se apropriar de parcelas dos fluxos de mercadorias que chegavam até a linha da fronteira. É comum na cidade de Corumbá a venda de produtos industrializados diversos realizada em pequena quantidade e oferecida a preço abaixo do mercado.

Considerando o circuito inferior das cidades-gêmeas da fronteira entre Brasil e Bolívia, com base em Santos (1979, p. 159 e 205) verifica-se que a caracterização desse espaço está constituída pela maioria da população pobre, migrante e, no geral, de citadinos desprovidos de capital e de qualificação profissional, que encontram trabalho mal remunerado em atividades econômicas regionais e urbanas de caráter sazonal e/ou instável e contam com pouca absorção no circuito superior. Pode-se acrescentar que parte dessas mulheres que praticam a atividade comercial em Corumbá se estabelece na cidade por meio dos seus núcleos familiares, onde formam seu "capital social".

Cabe destacar a descrição do trabalho familiar, segundo a observação de Tassi et al (2013), que tem o propósito de evidenciar a importância da unidade familiar para a elaboração de estratégias de como trabalhar no comércio popular. Assim também se constata nas unidades familiares na fronteira:

La família cumple, por ejemplo, el trabajo de investigar y sondear el mercado, para equiparar precios, para identificar las características de los productos con mayor "salida", las novidades con buenos márgenes de ganancia y hasta los nichos de mercado en donde poder insertarse. Estos estúdios de mercado familiares (...) se basan en conocimientos y prácticas empíricas y experienciales, 
en las relaciones cercanas con el grêmio y también con uma serie de compradores y vendedores. A través de estas relaciones, se genera una espécie de saber compartido y complejo, aunque semioculto, sobre mercados, rubros y precios al que las famílias de comerciantes acceden y manejan con una agilidade sorpresiva (TASSI et al, 2013, p. 159).

Outra observação interessante sobre a cultura comercial Aymara trata-se da perspectiva da estética comercial, que para as comerciantes Aymaras diz respeito à abundância de mercadorias, assim argumentam: Una tienda bien surtida no es sintoma de mercadoria no vendida, sino, por el contrario, es una expresión de êxito económico y, al mismo tempo, una forma de atracción comercial (TASSI et al., 2013, p.157).

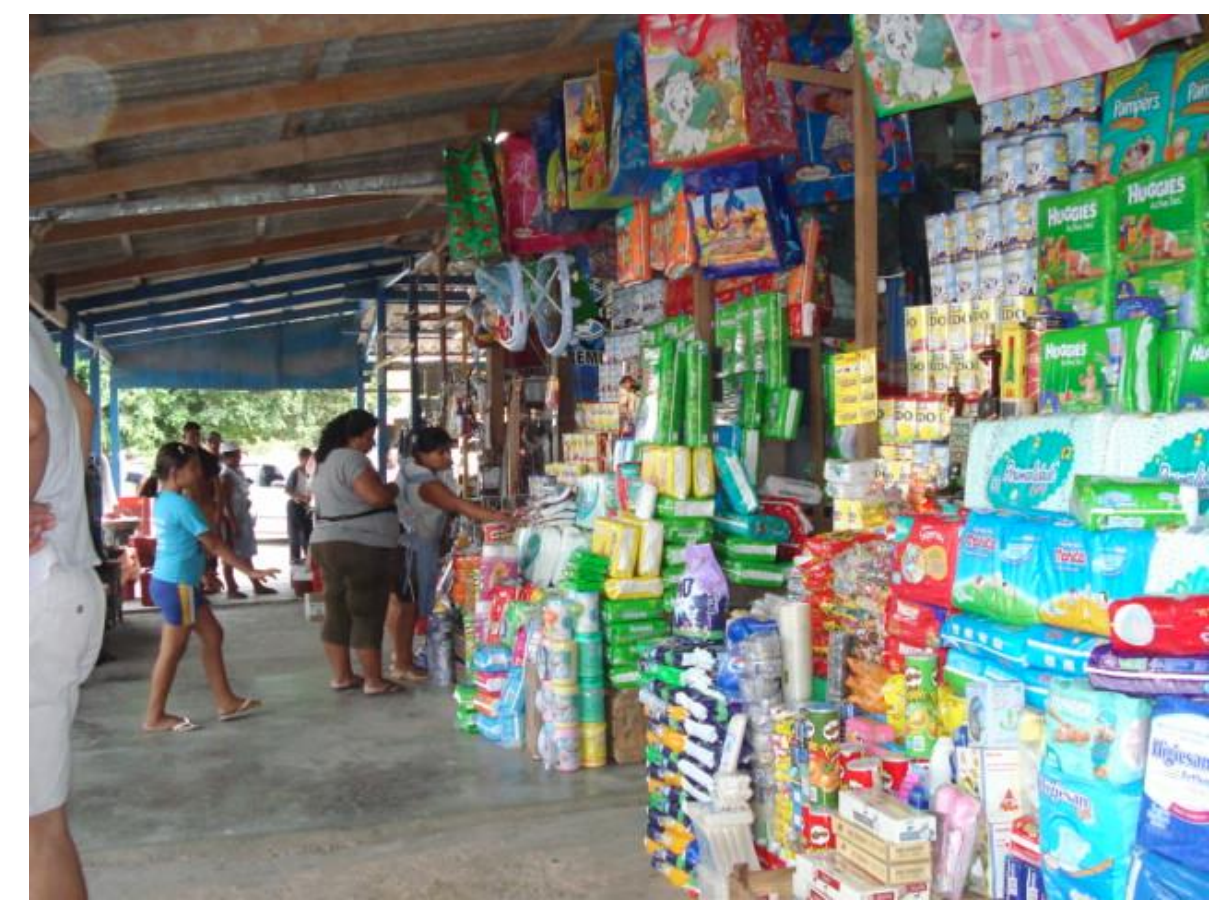

FOTO 27 - Brasil, Corumbá, Feira Brasbol, área destinada à comercialização de produtos de exportação provenientes de várias fronteiras da Bolívia.

Foto: SOKEN, D., março de 2013.

Constatou-se que a maioria das mulheres comerciantes de produtos de reexportação de Corumbá tem Cadastro Nacional de Pessoa Jurídica (CNPJ). Usam a figura empresarial para alugar prédios sucateados e também para comprar alguns produtos no comércio atacadista para fins de comprovação de origem da mercadoria. Além disso, ao realizarem o comércio dentro de um edifício não se configuram como ambulante porque não ultrapassam o limite do uso das calçadas, apesar disso, os produtos ainda continuam expostos nas calçadas. Geralmente esses espaços são utilizados como lugar de depósitos para os feirantes de bairros da cidade, bem como, também são lugares de residências. 


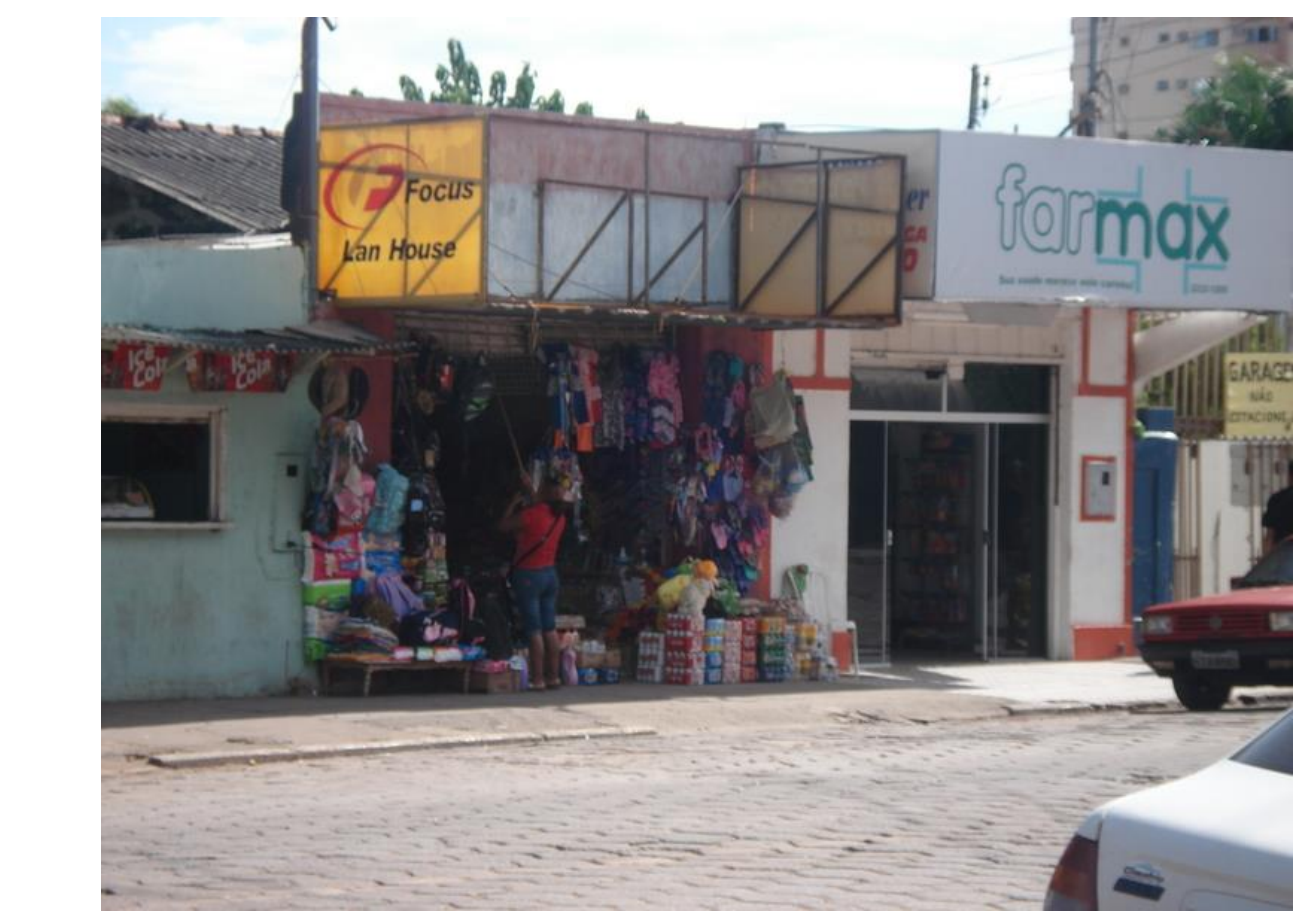

FOTO 28- Brasil, Corumbá, rua Dom Aquino, prédio residencial e comercial, estabelecimento de produtos diversos

Foto: SOKEN, D., março de 2013.

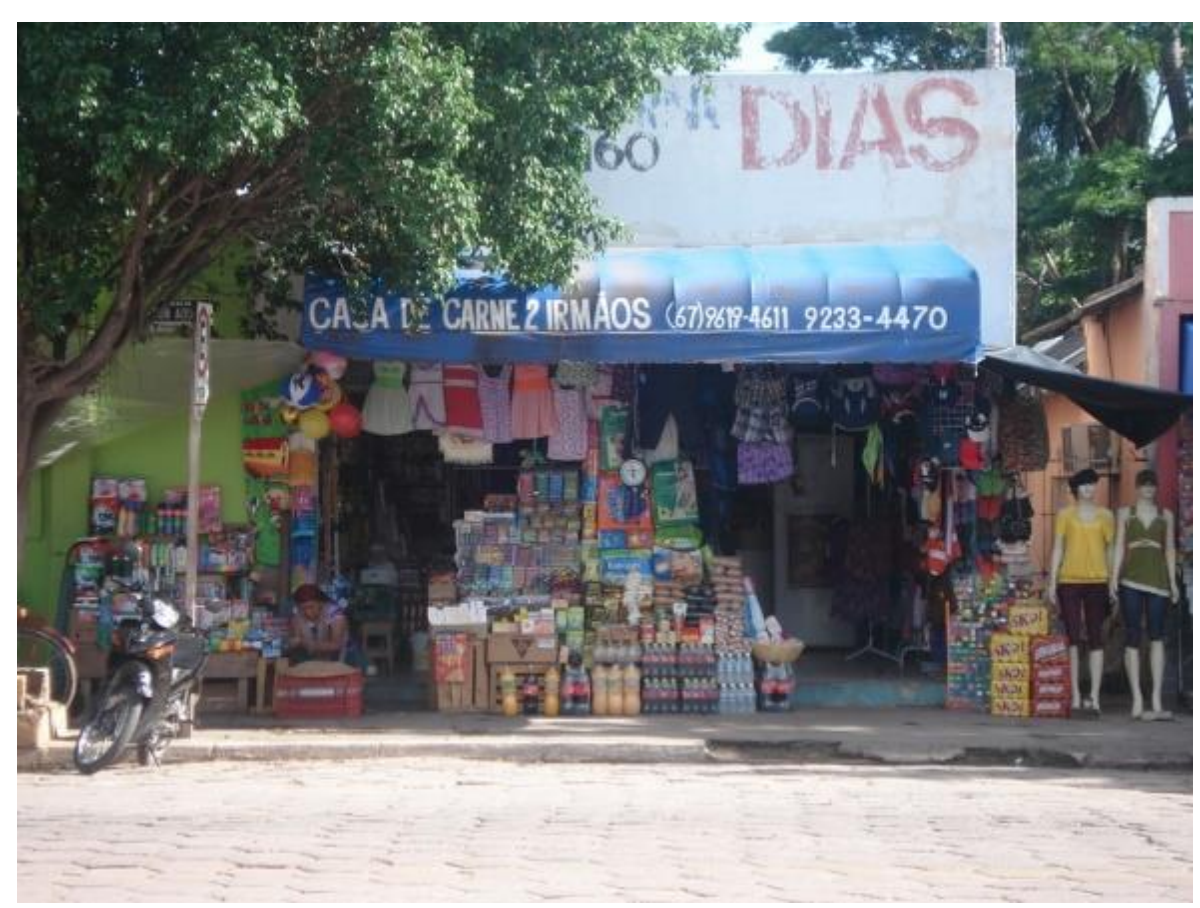

FOTO 29 - Brasil, Corumbá, rua Dom Aquino, prédio residencial e comercial, estabelecimento de produtos diversos

Foto: SOKEN, D., março de 2013. 
Segundo Milton Santos (1979, p.168) as explicações sobre a pulverização da atividade do comércio no circuito inferior têm conteúdos geográficos e socioeconômicos. Por um lado, as pessoas de baixo poder aquisitivo compram no próprio bairro, o custo do deslocamento as impede que comprar no comércio moderno geralmente localizado no centro ou nos arredores da cidade. Por outro lado, a capacidade de compra destas pessoas as possibilita a adquirir pequenas quantidades de produtos, mas são as condições de crédito e preço oferecidas pelo pequeno varejo que favorecem a manutenção dessa atividade.

Conforme o relato da srta. Sipaku, a maioria dos clientes desconhece o fato do de que o comércio popular é uma atividade legal, e, atualmente, é cadastrado como Microempresa Individual (MEI), portanto, essas microempresas recolhem impostos e taxas, têm custos com aluguel, tem despesas de água e luz, entre outros. Ainda, segundo Sipaku a atividade comercial da família boliviana sofre muita discriminação na cidade, há sempre aquele que pede desconto pois considera que todas as mercadorias estão isentas de impostos.

A família da srta. Sipaku sustenta um vínculo de negócios com os comerciantes atacadistas das cidades-gêmeas mediante o fornecimento de pequena quantidade de mercadorias a preços competitivos. Essa estratégia é mais vantajosa, porque não mantém mercadorias em estoque e consegue obter maior margem de lucro, fazendo a mercadoria girar mais rápido.

Pode-se dizer que o comércio de atacado de ambos os lados se beneficia dessa relação porque o trabalho de distribuição dos produtos de reexportação é realizado predominantemente pela mão de obra boliviana, cuja participação nos ganhos depende dessas famílias de comerciantes bolivianos de encontrar espaços pela cidade, não se importando com as condições precárias das instalações dos estabelecimentos e dos locais de comercialização. Uma vez com os produtos nas mãos, depende apenas da habilidade deles vender rápido e oferecer o maior número de mercadorias a preços mais competitivos.

Até o momento, é possível perceber que o comércio popular do lado boliviano continua em expansão e tem ocupado novas áreas, seja na proximidade da linha ou na faixa da fronteira brasileira. Constata-se que o preço de venda de boa parte das mercadorias provenientes de várias fronteiras está sempre abaixo do preço de mercado, 
não há um registro contábil das mercadorias que entram e saem. A comerciante fronteiriça realiza a venda com uma margem mais ou menos de $20 \%$ para todos os produtos, acreditase que o sistema de tributação do governo ainda não afetou a esse tipo de comércio que está definido em $23 \%$.

É interessante observar que muitos se importam apenas com a venda do dia, ou seja, o dinheiro que entra naquele dia de comércio será o que a família terá como se alimentar ou se vestir. Por isso, sempre estão em busca de novas oportunidades de negócios, sabem que a fronteira é um território de múltiplos usos, quando não está bom de um lado, buscam "la plata" de outro lado.

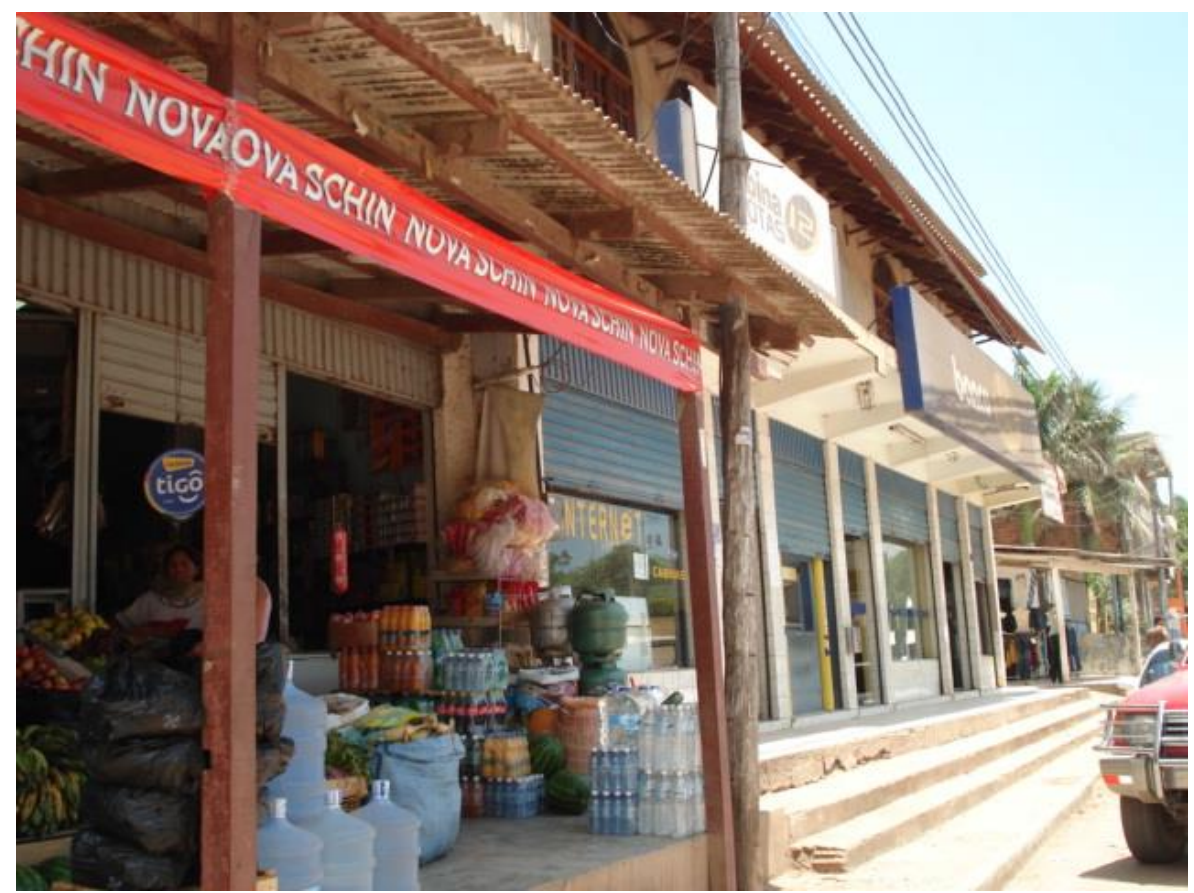

FOTO 30 - Bolívia, Arroyo Concepción em Puerto Quijarro, "tienda” de produtos diversos na avenida Luis Salazar de la Vega, situado na linha de fronteira. Foto: SOKEN, D., setembro de 2014. 


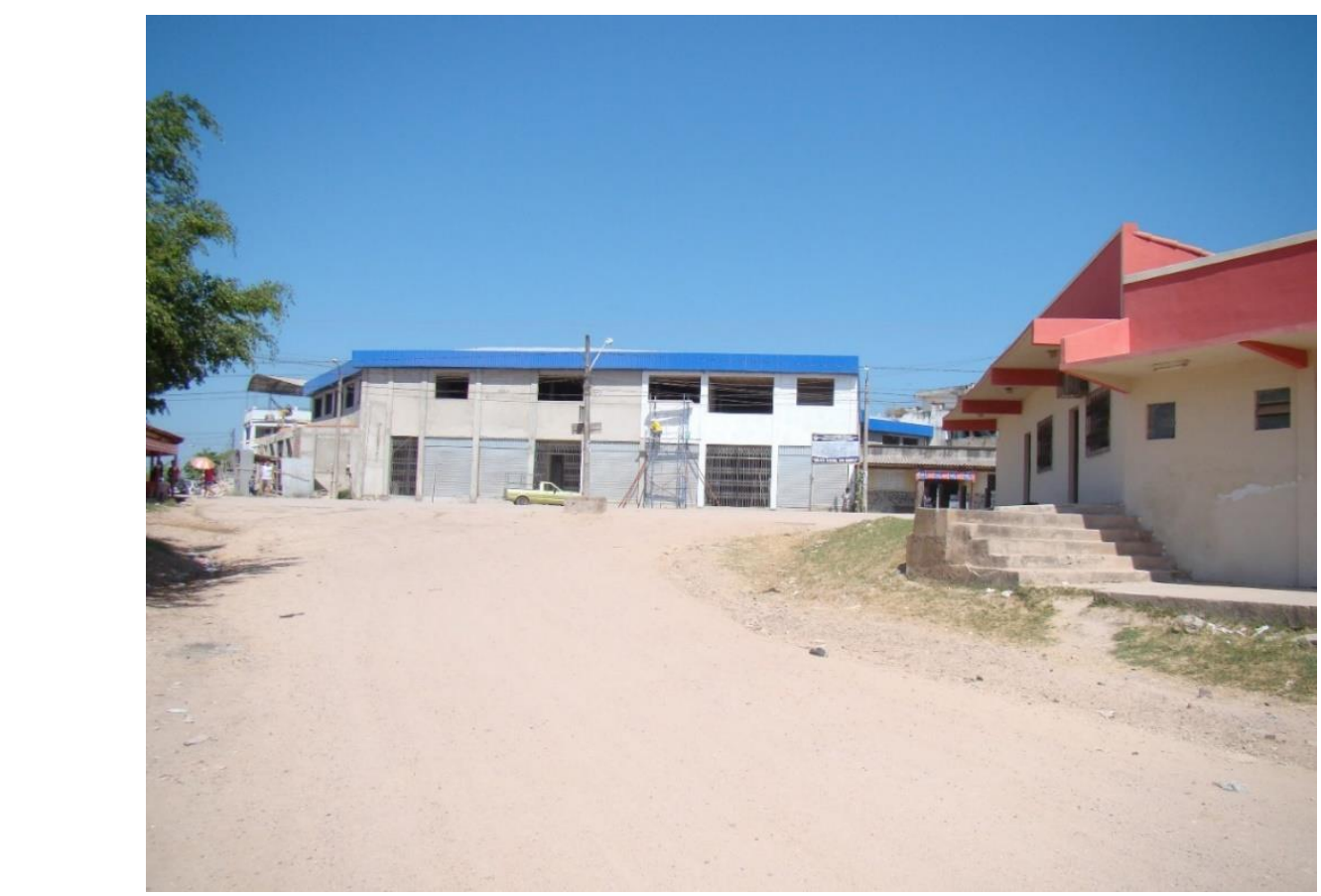

FOTO 31- Bolívia, Puerto Suarez, reforma do Mercado Popular "Nuestra Señora Del Carmen”, situado na faixa de fronteira.

Foto: SOKEN, D., setembro de 2014.

É interessante apontar o quanto as áreas do circuito inferior se expandem "a olhos nus", flagram-se constantes transformações neste espaço urbano, novos prédios comerciais são erguidos, reformas, construções e expansão de novas áreas comerciais, investimentos realizados pelas associações de comerciantes. 


\section{CONSIDERAÇÕES FINAIS}

A abordagem de gênero e de fronteira nesta pesquisa teve como princípio norteador a formação socioeconômica das cidades-gêmeas da fronteira entre Brasil e Bolívia que revelou os vários períodos de ocupação desse espaço fronteiriço. Duas frentes de ocupação se destacaram no estudo, as quais potencializaram as relações transfronteiriças, ao longo das décadas de 1990 e 2000: a circulação de produtos industrializados provenientes de várias fronteiras como a brasileira, a chilena, a peruana e a argentina e a expansão do comércio popular, especialmente de confecção, para as fronteiras bolivianas com uso da força de trabalho feminina.

Até o momento, verificou-se que o comércio popular "formiguinha" ocupado predominantemente por mulheres bolivianas e o comércio de exportação e importação foram os fatores que alavancaram a retomada do fluxo de mercadorias e pessoas para esse lado do país.

As cidades-gêmeas de fronteira internacional por definição são lugares de (re) produção de acumulação do circuito comercial transfronteiriço. Tal configuração do lugar está direcionada para um determinado fluxo de negócios de ordem internacional, vinculado aos circuitos comerciais mais dinâmicos, como por exemplo, o comércio de produtos alimentícios industrializados, eletroeletrônicos e perfumarias procedentes de mercados de importações como o Brasil, o Chile, o Peru, o Panamá e os Estados Unidos, além da produção de vestuário cruzeña e de outras cidades do altiplano boliviano. E em contrapartida estabelece outro fluxo de turistas e "sacoleiras" provenientes de várias localidades do Brasil e Bolívia que se deslocam em massa até a linha de fronteira. Desta forma, essa localidade se apresenta como lugar de relações comerciais transfronteiriças, ou seja, as relações fronteiriças transbordam para além da linha ou faixa de fronteira entre Brasil e Bolívia.

Entende-se que a produção do espaço feminino de fronteira, especificamente da fronteira entre Brasil e Bolívia é resultado das relações comerciais, produtivas e institucionais do período técnico-científico-informacional, onde as leis, normas, regras de controle do lugar "fronteiriço" revelam as assimetrias apropriadas pelos atores dos circuitos superior e inferior. 
Quando ocorrem alterações nas regras e de controle do fluxo de mercadorias e pessoas nos lugares de fronteira, novos ambientes de competição são criados para os atores do processo de acumulação, vinculados tanto ao circuito superior (no caso do comércio atacadista e da indústria de confecção com uso de mão de obra), quanto ao circuito inferior (comércio popular), uma vez que são interdependentes. Sendo assim, o processo de acumulação do circuito inferior também é impactado pelas mudanças das regras do circuito superior.

A expansão do comércio popular na fronteira serve de indicador da produção de confecção bolivianas, uma vez que a produção é determinada pela dinâmica da reprodução do produto, ou seja, a cópia que circula nas cidades do altiplano boliviano acaba chegando até as fronteiras. Desta forma, os produtos comercializados na fronteira já têm incorporado o baixo custo da mão de obra e a tecnologia de reprodução do produto original.

A fronteira é o território que articula o processo de acumulação, é lugar do "espaço local", ou seja, espaço de todos para se tornar "território transnacionalizado". O poder das redes familiares é intensificado pelas relações fronteiriças por meio da definição de preço do produto no comércio popular. Os preços de produtos populares no mercado brasileiro são suficientes para dar sobrevida ao comércio transfronteiriço, ou seja, quanto maior é o preço do mercado local, mais amplo será o mercado popular. Portanto, constatou-se que a melhor estratégia utilizada pelas mulheres que atuam nesse comércio popular é a discriminação de preços no mercado corumbaense.

Os espaços ocupados pelas mulheres do comércio popular, seja com a venda de alimentos industrializados ou vestuário (procedentes do circuito espacial produtivo brasileiro e boliviano) cumprem a função social de reprodução familiar. A maioria revela que o trabalho por conta própria é a condição de sobrevivência e o sacrifício do trabalho excedente está reproduzido pelo bem-estar da família e pela ascensão social dos filhos.

Observou-se a importância da cidade de Corumbá na distribuição de produtos alimentícios para as demais cidades desta fronteira, assim como a complementaridade de Puerto Quijarro e Puerto Suarez tanto da distribuição de produtos alimentícios quanto de outros produtos industrializados. Sob a possibilidade de existir integração e complementação econômica entre as cidades gêmeas, a condição fronteiriça de 
contiguidade geográfica tem se colocado como oportunidade às mulheres que trabalham na fronteira para incrementar os fluxos comerciais entre estas duas Nações. Desta forma, constatou-se que essa faixa de fronteira é permeável, no entanto, evidencia que os movimentos das mulheres se diferenciam pelos fluxos (compras, trabalho e visita familiar) são mais intensos do que os movimentos pelos fixos (residência, saúde, escola).

É importante dizer que o comércio internacional desta área de fronteira possibilitou a diversificação, ampliação da oferta de mercadorias e o desenvolvimento de infraestrutura. Há ônibus e voos comerciais que saem de Corumbá com destino as cidades de Campo Grande, capital do estado de Mato Grosso do Sul, e Campinas no estado de São Paulo ou de Puerto Suarez para a capital Santa Cruz de La Sierra. Em relação ao transporte ferroviário, apenas em Puerto Quijarro e Puerto Suarez realizam o transporte de passageiros e cargas, este é o transporte mais utilizado pelos comerciantes do circuito inferior da Bolívia com destino aos mercados atacadistas.

O tipo de consumo popular do circuito inferior é que mantém o nível de empregabilidade de mulheres nesta área de fronteira, bem como, a organização da estrutura familiar. Sobretudo, o rendimento do trabalho no comércio da maioria das mulheres é destinado para suprir as necessidades com alimentação, habitação e educação dos filhos, ou seja, para garantir a reprodução da vida.

Constatou-se que as mulheres trabalhadoras do comércio transfronteiriço apontaram a remuneração da atividade como o principal motivo de morar e trabalhar nas cidades-gêmeas entre Brasil e Bolívia. Além disso, observou que outras características dessa atividade mantêm a concentração da mão de obra feminina, como a possibilidade de desenvolver o próprio negócio, como também de encontrar o primeiro emprego ou dar continuidade ao negócio da família.

Verificou-se que a principal característica norteadora da dinâmica dos dois circuitos das cidades de fronteira diz respeito à duplicidade dos investimentos, pois as mulheres detentoras do capital mercantil atuam nos dois lados da fronteira, investem em bens imóveis residenciais ou comerciais e outras adquirirem produtos populares. Observou-se que o investimento com a educação dos filhos corresponde à fase posterior do processo de acumulação, a casa própria é a prioridade. No geral, constatou-se que as mulheres que trabalham no circuito inferior das cidades-gêmeas foram as responsáveis 
pela pulverização das relações transfronteiriças, mediante as formas de organização dos negócios e do trabalho e, principalmente, pelo estreitamento dos laços familiares.

Outro elemento fundamental para o funcionamento das atividades dos circuitos da economia urbana da fronteira é o uso de várias moedas. Neste espaço fronteiriço a circulação de mais de uma moeda torna-se uma necessidade vital para os negócios dos dois circuitos urbanos. Pois, as variações cambiais do mercado de moeda local favorecem a manutenção dos preços dos produtos em nível de concorrência frente aos mercados mais competitivos. No caso do circuito inferior, o uso destas três moedas Real, Dólar e Peso Boliviano necessário para as transações diárias nesta fronteira é um dos elementos utilizados pelas mulheres comerciantes para suprir a carência de capital de giro

Percebe-se que as famílias de comerciantes bolivianas que conseguiram se instalar na área central da cidade de Corumbá encontraram espaços diversos para oferecer suas mercadorias, algumas alugaram prédios sucateados, outras ocuparam corredores de garagens ou se instalaram nas calçadas da cidade. Essa forma de ocupar a cidade, de certo modo tem estabelecido novos usos dos equipamentos urbanos envelhecidos, todavia, pode reestruturar a especulação imobiliária que há tempos vigora na cidade, mas sobretudo, essa ocupação desordenada dos espaços pelas famílias bolivianas aumentou a intervenção do poder público do local sobre as atividades comerciais do circuito inferior.

Os conflitos fronteiriços existentes nessas localidades são originários dos estranhamentos causados pelas dinâmicas externas ao lugar. Por ora, constatou-se que a atividade comercial da cidade de Corumbá esteve vinculada a dinâmica da indústria de mineração, portanto, as decisões são de fora para dentro do território. Por outro lado, as cidades bolivianas, Puerto Quijarro e Puerto Suarez, na linha da fronteira estavam articuladas com as cidades do altiplano boliviano e com a capital do departamento de Santa Cruz, bem como, com as "sacoleiras" brasileiras provenientes de várias localidades do estado de Mato Grosso do Sul. Tais relações estão suportadas pelas taxas cambiais e preços dos produtos locais, para tanto, é louvável pensar o espaço de fronteira a partir do local, ideia que Santos (2000, p. 95) retoma quando discute a constituição de uma federação de lugares, onde introduz a noção de "nação, solidariedade nacional, Estado nacional" e venha a construir o território compartimentado e resistente a fragmentação. 
$\mathrm{O}$ circuito inferior tem maior impacto sobre o local, enquanto que o circuito superior a relação é determinada fora da cidade. Portanto, podemos afirmar que a contribuição do trabalho feminino na fronteira se dá pela construção do meio urbano, diretamente pelo aumento da densidade das atividades urbanas e indiretamente pelo crescimento do número de casas, hospitais, escolas, creches, expansão do saneamento básico, etc... "O circuito inferior encontra os elementos de sua articulação na cidade e sua região, enquanto que o circuito superior vai ordinariamente buscar essa articulação fora da cidade e de sua região" (Santos, 1979, p.37).

A presença do trabalho feminino no circuito inferior retrata a dialética do sistema da economia urbana, nas cidades gêmeas da fronteira esta mão de obra é altamente funcional, a produtividade do trabalho desse circuito é elevada, pois reproduz e expande o consumo dos dois circuitos espaciais para outras localidades e, ao mesmo tempo, conserva o papel de fornecedor de empregos.

E para fins de futuras pesquisas, constatou-se que alguns dos negócios da fronteira referente aos artigos de luxo, tais como: perfumes importados, bebidas, artigos de decoração e de pesca são coordenados em sua maioria pelas famílias corumbaenses de descendência árabe, com larga experiência no comércio transfronteiriço. 


\section{BIBLIOGRAFIA}

ABIT. Indústria Têxtil e de Confecção Brasileira. Cenários, desafios, perspectivas e demandas. Brasília, junho de 2013.

ALADI/AAP/A14TM/5. Acordo de Santa Cruz de la Sierra. Valle de las Leñas, Argentina, 1992.

AZEVEDO, F. de. Um trem corre para o oeste. Estudo sobre a Noroeste e seu papel no sistema de viação nacional. São Paulo: Livraria Martins Editora, 1950.

BACKHEUSER, E. Curso de Geopolítica Geral e do Brasil. Rio de Janeiro: Biblioteca do Exército, vols. 178-179, 1952.

BLAY, E. A. A mulher e o trabalho qualificado na indústria paulista. São Paulo: FFLCH/USP, (Tese de doutorado), 1972.

Trabalho domesticado: a mulher na indústria paulista. Ensaios, 35. São

Paulo: Editora Ática, 1978

BNDES/Setorial. Rio de Janeiro, n.29, março, 2009.

BOLÍVIA/Instituto Nacional de Estadística - MERCOVI/Censo Nacional de População e Moradia - 1976 e 1992. Sítio: www.ine.gob.bo.

Instituto Nacional de Estadística. Estadísticas Estruturales da la Industria manufacturera, Comercio y Servicios - 2010. La Paz, agosto de 2012.

BORGES, F. T. M., Do extrativismo à pecuária: algumas observações sobre a história econômica de Mato Grosso (1870 a 1930). Cuiabá, 1991.

BRASIL/Instituo Brasileiro de Geografia e Estatística. PNAD; vários censos. Sítio: www.ibge.gov.br.

BRASIL. Departamento Nacional de Produção Mineral. Sumário mineral. Brasília, DNPM, 2014.

BRUSCHINI, C. Desigualdades de Gênero no Mercado de Trabalho Brasileiro: o Trabalho da Mulher nos Anos Oitenta. IN: Fernandes, Reynaldo (org.). O Trabalho no Brasil no Limiar do Século XXI, São Paulo: Editora LTr, 1995.

CALIO, S. A. Relações de gênero na cidade: uma contribuição do pensamento feminista à geografia urbana. São Paulo: Departamento de Geografia/FFLCH/USP, (Tese de doutorado), 1991.

CAMPESTRINI, H. História de Mato Grosso do Sul. $7^{\text {a }}$ edição. Campo Grande, MS, SESC, 2011.

CARTER, W. e ALBÓ, X. La comunidade Aymara: un mini-estado en conflito. IN: ALBÓ, X. Raíces de América: El mundo Aymara. Madrid: UNESCO/Alianza Editorial, 1988. 
CARVALHO, C. M. D. de. Geografia das Fronteiras. IN: Revista Brasileira de Geografia, 1939, Jul, vol. 1, n³, p. 95-110.

CARVALHO, M.J.S. e ROCHA, C.M.F. (orgs.). Produzindo gênero. Porto Alegre: Sulina, 2004.

CATAIA, M. A. Fronteiras: territórios em conflitos. IN: XIII Encontro Paranaense de Estudantes de Geografia. Marechal Cândido Rondon, Universidade Estadual do Oeste do Paraná. 2008

Território Nacional e Fronteiras Internas. A fragmentação do território brasileiro. São Paulo: USP/FFLCH/Departamento de Geografia, 2001 (tese de doutoramento)

CHABAUD, D. e FOUGEYROLLAS-SCHWEBEL, D.. Sobre a autonomia relative da produção e da reprodução. IN: KARTCHEVSKY-BULPORT, A. et all. O sexo do trabalho. Rio de Janeiro: Editora Paz e Terra, 1986.

CORRÊA, L. S. Corumbá: um núcleo comercial na fronteira de Mato Grosso (18701920). São Paulo: USP/FFLCH, departamento de História, (Dissertação de mestrado), 1980.

CORREA, V.B. Casario do Porto de Corumbá. Campo Grande: Fundação de Cultura de MS; Brasília: Gráfica do Senado, 1985.

Corumbá (um esboço histórico). Corumbá/MT: Universidade Estadual de Mato Grosso/Centro Pedagógico de Corumbá, caderno 2, 1973.

CORREA FILHO, V. As raias de Matto Grosso. São Paulo: Secção de obras "Estado de São Paulo", 1925. V. III.

COSTA, A. O. e BRUSCHINI, C. (orgs.). Uma questão de gênero. Rio de Janeiro: Rosa dos tempos; São Paulo: Fundação Carlos Chagas, 1992.

COSTA, R.H. da. e PÔRTO-GONÇALVES, C.W. A nova des-ordem mundial. São Paulo: Editora UNESP, 2006.

COSTA, W.M. de. Geografia Política e Geopolítica: Discursos sobre o Território e o Poder. São Paulo: Editora da Universidade de São Paulo; Hucitec, 1992.

1997.

O estado e as políticas territoriais no Brasil. São Paulo: Ed. Contexto,

DEDDECA, C. Tempo, Trabalho e Gênero. IN: COSTA, A. A.; OLIVEIRA, E. M.; LIMA, M. E. B. e SOARES, V. [orgs.]. Reconfiguração das relações de gênero no trabalho. São Paulo: CUT Brasil, 2004. Disponível em: http://www.ie.ufrj.br/aparte/pdfs/nota_tecnica_tempo_trabalho_e_genero.pdf)

DE LA O, M.E. El trabajo de lãs mujeres em la industria maquiladora de México: balance de cuatro décadas de estúdio. IN: Revista de Antropologia Iberoamericana. Ed. Eletrónica Vol 1. Num. 3 Agosto-Diciembre 2006. P. 404-427. 
DIEESE - Departamento Intersindical de Estatística e Estudos Sócioeconômicos.

A inflação e os juros. São Paulo: Nota Técnica, n. 122, abril de 2013. Sítio: www.dieese.org.br. Acesso em 27/10/2013

Mulheres e os salários mínimos nos mercados de trabalho metropolitanos. São Paulo: Estudos e Pesquisas, ano 3, n.32, março de 2007. Sítio: www.dieese.org.br. Acesso em 27/10/2013

ESSELIN, P. M. Gêneses de Corumbá: Confluência das frentes espanholas e Portuguesas em Mato Grosso. Edufems. Campo Grande, 1999.

FAGALDE, E. A. Participación de la mujer en atividades de maquila y subcontratación en la ciudad de El Alto: Estudios de caso en Textiles, Artesania y Joyería. IN: Cuaderno de Trabajo n.9, Red Mujeres y Economia Bolívia, La Paz, 2004.

FIORI, J. L. O poder global e a nova geopolítica das nações. São Paulo: Boitempo Editorial, 2007

FREIRE, E.M. Bolívia: crise de coesão territorial no coração da América do Sul". São Paulo: FFLCH/USP, (dissertação de mestrado), 2008

FOUCHER, M. Obsessão por fronteiras. São Paulo: Radical livros, 2009.

GAERTNER, L. Prefeito afirma que interdição é medida para estrutura comércio popular. Diário On line. Corumbá, 16 de mai. 2013. www.diarioonline.com.br. Acesso em 16 de maio de 2013.

GARCIA-RAMON, M. D. El análisis de genero y la geografia: reflexiones en torno a un libro reciente. IN:Documents d'Analisi Geografica, 6, 1985, pp. 133-143

- Genero, espacio y entorno: hacia una renovacion conceptual de la Geografia? Una introduccion. IN: Documents d'Analisi Geografica 14, 1989, pp. 7-13

GARDEY, D. Perspectivas históricas. IN: MARUANI, M.; HIRATA, H. (orgs.). As novas fronteiras da desigualdade: homens e mulheres no mercado de trabalho. São Paulo: Editora Senac, 2003.

GORINI, A.P.F. Panorama do setor têxtil no Brasil e no Mundo: reestruturação e perspectivas. BNDES Setorial, Rio de Janeiro, n.12, p. 17-50, set. 2000.

GRAY MOLINA, G. La economia boliviana "mas allá del gas". Revista America Latina hoy, 43, 2006, p.63-85. Ediciones Universidad de Salamanca

GUMUCIO, M. B. Breve historia contemporânea de Bolivia. México: Fondo de Cultura Económica, 1996.

HARDMAN, M. J. JAQI ARU: la lengua humana. IN: ALBÓ, X. Raíces de América: El mundo Aymara. Madrid: UNESCO/Alianza Editorial, 1988

HARVEY, D. A condição pós-moderna: uma pesquisa sobre as origens da mudança cultural. São Paulo: Ed. Loyola, 1993. 
A produção capitalista do espaço. São Paulo: Annablume, 2005.

HIRATA, H. e KERGOAT, D. Divisão sexual do trabalho profissional e doméstico: Brasil, França, Japão. IN: COSTA, A. O.; SORJ, B.; BRUSCHINI, C. e HIRATA, H. (orgs.). Mercado de trabalho e gênero: comparações internacionais. Rio de Janeiro: Editora FGV, 2008.

HIRATA, H. Nova divisão sexual do trabalho? Um olhar voltado para a empresa e a sociedade. São Paulo: Editora Boitempo, 2002.

HOBSBAWM, E.J. Nações e nacionalismo desde 1780. Programa, mito e verdade. (Tradução de Maria Celia Paoli e Anna Maria Quirino). São Paulo: Editora Paz e Terra, 2011.

ITO, C. A. Corumbá: o espaço da cidade através do tempo. Campo Grande/MS: Editora UFMS, 2000.

KARSTCHEVSHY, A. et al. O sexo do trabalho. Rio de Janeiro: Ed. Paz e Terra, 1986.

KARSTEN, L. e MEERTENS, D. La Geografia del gênero: sobre visibilidad, identidad y relaciones de poder. Documents D’Analisi Geografica, 19-20, 1991, pp. 181-193.

KON, A. A Economia Política do Gênero. IN: Revista de Economia Política, vol. 22, $\mathrm{n}^{\circ}$ 3 (87), julho-setembro/2002

LEHNEN, A.C.; CASTELHO, I.R. e SCHÄFFER, N.O. (orgs.). Fronteiras no Mercosul. Porto Alegre: Editora da Universidade/UFRGS/co-edição Prefeitura Municipal de Uruguaiana, 1994.

MACHADO, L. O. Limites, Fronteiras, Redes. In: STROHAECKER, T. M., A.; SCHAFFER, D.N.O.; BAUTH, N.; DUTRA, V.S. (orgs.). Fronteiras e Espaço Global, AGB-Porto Alegre, Porto Alegre, 1998.

. Estado, territorialidade, redes. Cidades-gêmeas na zona de fronteira sulamericana. IN: SILVEIRA, M. L. (org). Continente em chamas: globalização e território na América Latina. Rio de Janeiro: Civilização Brasileira, 2005.

MACHADO, L.; HAESBAERT, R.; RIBEIRO, L.P.; STEIMAN, R.; PEITER, P. e NOVAES, A. "O desenvolvimento da faixa de fronteira: uma proposta conceitualmetodológica." IN: OLIVEIRA, T. C.M de. (org.). Território sem limite: estudos sobre fronteiras. Campo Grande, MS: Editora UFMS, 2005, p. 87 a 112.

MAMIGONIAN, A. Inserção de Mato Grosso ao mercado nacional e a gênese de Corumbá. Revista Geosul, n.1, 1º semestre, 1986.

MARUANI, M. Emprego, desemprego e precariedade: uma comparação europeia. IN: COSTA, A. O. de; SORJ, B.; BRUSCHINI, C.; HIRATA, H. (orgs.). Mercado de trabalho e gênero: comparações internacionais. Rio de Janeiro: Editora FGV, 2008.

MARTIN, A. R. Fronteiras e Nações. São Paulo: ed. Contexto, 1992. 
MATESCO, V.R. e LAVINAS, L. A reestruturação produtiva nas empresas brasileiras e seu reflexo sobre a força de trabalho, por gênero. In: IPEA. Texto para discussão no 400 , janeiro de 1996.

MATO GROSSO DO SUL. Secretaria de Estado de Meio Ambiente, do Planejamento, da Ciência e Tecnologia. Diagnóstico Socioeconômico de Mato Grosso do Sul. Campo Grande, MS, 2009.

MEDEIROS, M. e J. COSTA. Is There a Feminization of Poverty in Latin America? World Development. PNUD/IPEA, 2008, 36(1): 115-127.

MELLO, L.I. A. A geopolítica do Brasil e a Bacia do Prata. Manaus: Editora da Universidade do Amazonas, 1997.

MENDONÇA, R. Fronteira em marcha. Ensaio de uma geopolítica brasileira. Rio de Janeiro: Livraria São José, 1956.

MESA, J.; GISBERT, T.; GISBERT, C.D.M. Historia de Bolivia. La Paz: Editorial Gisbert y cia S.A., 2008.

MÉSZÁROS, I. Para além do capital: rumo a uma teoria da transição. São Paulo: Ed. Boitempo, 2002.

MODIE, A. E. Geografia e Política. Tradução Christiano Monteiro Oiticica. Rio de Janeiro: Ed. Zahar, 1965.

MORAES, A. C. R. Geografia: pequena história crítica. São Paulo: Annablume, 2005.

MOREIRA, R. Esboço histórico das nossas questões de fronteira. São Paulo: Instituto Historico e Geographico, 1913.

NAPOLEONI, C. Lições sobre o capítulo sexto (inédito) de Marx. São Paulo: Livraria Editora Ciências Humanas, 1981.

NEVES, M. A. Reestruturação produtiva, qualificação e relações de gênero. IN: ROCHA, M.I.B. da. (org). Trabalho e Gênero: mudanças, permanências e desafios. Campinas: ABEP, NEPO/UNICAMP E CEDEPLAR/UFMG. São Paulo: Editora 34, 2000

NUNES, R. Ministério Público instaurou inquérito em 2011 para apurar funcionamento da "feirinha". Diário On line. Corumbá, 16 de mai. 2013. www.diarioonline.com.br. Acesso em 16 de maio de 2013.

OLIVEIRA, T.C.M. Uma fronteira para o pôr-do-sol: um estudo geo-econômico sobre uma região de fronteira. Campo Grande, MS: Ed. UFMS, 1998, 148p.

Tipologia das relações fronteiriças: elementos para o debate teóricoprático. In: OLIVEIRA, T.C.M. (org). Território sem limites. Campo Grande-MS: Editora Universidade Federal de Mato Grosso do Sul, 2005.

Condições de conurbação internacional (o caso de Corumbá-Puerto Quijarro-Puerto Suárez). IN: OSÓRIO, A. C. N.; PEREIRA, J.H.V. e OLIVEIRA, 
T.C.M. (orgs.). América Platina: educação, integração e desenvolvimento territorial: textos escolhidos. Vol. I. Campo Grande, MS.: Editora UFMS, 2008, p. 233-254.

Os elos da integração: o exemplo da Fronteira Brasil-Bolívia. IN:

COSTA, E.A. \& OLIVEIRA, M. A.M.(orgs.) Seminários de Estudos Fronteiriços. Campo Grande - MS: Ed. UFMS, 2009.

ORGANIZAÇÃO INTERNACIONAL DO TRABALHO (OIT). "Mundialización cambia la fisionomía de las industrias del calzado, los textiles y el vestido". Informe, 28 de octubre, 1996. OIT/96/33 ISBN 92-2-310182-4.

Salarios y tempo de trabajo en los sectores de los textiles, el vestido, el cuero y el calzado. Ginebra, 2014.

PAIXÃO, R. Turismo regional: problemas e perspectivas. In: IV Simpósio sobre Recursos Naturais e Sócio-Econômicos do Pantanal. Corumbá/MS, 23-26 de novembro, 2004.

PEBAYLE, R. As regiões de fronteira e o projeto de integração do Mercosul. IN: LEHNEN, et al (org). Fronteiras do Mercosul. Porto Alegre: Ed. UFRGS, p. 100-115, 1994.

PFRIMER, M. H. e ROSEIRA, A. M. Transformações Territoriais na Bolívia: Um Novo "Triangulo Estratégico"?. In: 12 ${ }^{\circ}$ Encuentro de Geógrafos de América Latina. Montevideo, 2009.

POCHMANN, M. O emprego na globalização: a nova divisão internacional do trabalho e os caminhos que o Brasil escolheu. São Paulo: Boitempo Editorial, 2005.

POVEDA, P. Trabajo, informalidad y acumulación: Formas de producción y transferencia de excedentes de la industria manufacturera boliviana. La Paz: CEDLA, 2003, agosto, n.30.

PRESCOTT, J. R. V. The Geography of Frontiers and Boundaries. London, Hutchinson University Library, 1965.

RAFFESTIN, C. Por uma Geografia do Poder. São Paulo: Editora Ática, 1993.

A ordem e a desordem ou os paradoxos da fronteira. IN: OLIVEIRA, T.C.M.(org.) Territórios sem limites: estudos sobre fronteiras. Campo Grande - MS: Ed. UFMS, 2005.

RATZEL, F. O Solo, a Sociedade e o Estado. Tradutor Mário Antonio Enfrásio. São Paulo: Pós-Graduação em Geografia, FFLCH/USP, ago. de 1982.

REVISTA ETI-CIDADE. Imigrantes bolivianos escravizados. Disponível em http://www.etni-cidade.net/bolivianos_escravizados.htm. Acessado em 07/10/2006

ROCHA, M.I.B. da. (org.). Trabalho e gênero: mudanças, permanências e desafios. São Paulo, Campinas, ABEP, NEPO/UNICAMP e CEDEPLAR/UFMG. Editora 34, 2000. 
RODRIGUES, L.A. Geopolitica do Brasil. Rio de Janeiro: Biblioteca Militar, v. CXI, 1947.

ROSSINI, R. E. Geografia e Gênero: a mulher na lavoura canavieira paulista. São Paulo: Departamento de Geografia/FFLCH/USP. Tese de livre-docência, 1988.

A Mulher na Palha da Cana: Familia e Trabalho.. In: VII ENCONTRO NACIONAL DA ABEP. ANAIS DO VII ENCONTRO NACIONAL DA ABEP. CAXAMBU - MG - BRASIL, 1990. v. 2. p. 335-354.

As geografias da modernidade - geografia e gênero - mulher, trabalho e família. O exemplo da área de Ribeirão Preto - SP. IN: Revista do Departamento de Geografia, n.12, p.7-26. São Paulo: Universidade de São Paulo, 1998.

. Nas atividades econômicas a modernidade tecnológica exclui homens e mulheres. Incorpora mais a mulher na cidade e menos no campo. IN: Revista Geousp Espaço e Tempo, São Paulo, nº 12, ano 2002.

SANCHEZ, J. E. As ambiguidades da Divisão Territorial: desenvolvimento harmônico ou exclusão dos circuitos produtivos? IN: BECKER, B. e MIRANDA, M. (orgs.) A Geografia Política do Desenvolvimento Sustentável. Rio de Janeiro: Editora da UFRJ, 1997.

SANDOVAL, A.D. (org.). Redes económicas y sociales del transporte interprovincial en Santa Cruz. Estudio exploratório. La Paz: Jatupeando; Embajada del Reino de los Países Bajos; Fundación PIEB, 2013

SANTOS, M. A natureza do espaço: Técnica e Tempo, Razão e Emoção. 4 ed. 2.reimpr. São Paulo: Editora da Universidade de São Paulo, 2006.

Paulo, 2009.

A pobreza urbana. $3^{\text {a }}$.ed. São Paulo: Editora da Universidade de São

Metamorfoses do Espaço Habitado: Fundamentos Teóricos e Metodológicos da Geografia. 6. ed. 1. reimpr. São Paulo: Editora Hucitec, 2012.

O Espaço Dividido: os dois circuitos da economia urbana dos países subdesenvolvidos. Rio de Janeiro: Editora Francisco Alves, 1979.

Técnica, Espaço, Tempo: Globalização e Meio Técnico-Científico Informacional. São Paulo: Ed. Hucitec, 1994a.

O retorno do território. In: SANTOS, M.; SOUZA, M. A. A.; SILVEIRA, M. L. (orgs). Território: Globalização e Fragmentação. São Paulo: Editora Hucitec, Anpur, 1994b.

A urbanização brasileira. São Paulo: Editora Hucitec, 1998.

Nação ativa, nação passiva: a descontrução do território brasileiro. IN:

Caderno de Geografia. v. 11, n. 17, $2^{\circ}$ sem., p. 9-24. Belo Horizonte: PUC Minas, 2001. 
Por uma outra globalização: do pensamento único à consciência universal. $2^{\text {a }}$ edição. Rio de Janeiro: Editora Record, 2000.

SANTOS, M. e SILVEIRA, M. L. O Brasil: território e sociedade no início do século XXI. 15a ed. Rio de Janeiro: Editora Record, 2011.

SANTOS, M., SOUZA, M. A., SILVEIRA, M. L. Território, globalização e fragmentação. São Paulo: Editora Hucitec/ ANPUR, 1994

SCOTT, J. El genero: una categoria util para el analisis historico. IN: Historia y gênero. Las mujeres en la Europa Moderna y contemporánea. Instituto Valenciana D'estudis i investigació, 1990

SEGNINI, L.R. P. Mulheres no Trabalho Bancário: Difusão Tecnológica, Qualificação e Relações de Gênero. São Paulo: Ed. USP, 1998.

SILVA, M. M. F.. Fronteiras internacionais. IN: Instituto Brasileiro de Geografia e Estatística. Revista Brasileira de Geografia, 1941, v.3,n.3. p. 626-635.

SILVA, S. da. Bolivianos: a presença da cultura andina. São Paulo: Companhia Editora Nacional, 2005

SILVEIRA, M. L. Globalização, funcionamento técnico e funcionamento político na rede urbana Argentina e nordpatagônica. In: SANTOS, M.; SOUZA, M. A. A.; SILVEIRA, M. L. (orgs). Território: Globalização e Fragmentação. São Paulo: Hucitec, Anpur, 1994.

- Metrópolis brasileñas: un análisis de los circuitos de la economía urbana. Revista eure (Vol. XXXIII, N 100), pp. 149-164. Santiago de Chile, dez. de 2007.

SMITH, N. Desenvolvimento Desigual. Natureza, capital e a produção do Espaço. Rio de Janeiro: Ed. Bertrand, 1988.

SOUZA, M. A. de. Território brasileiro: usos e abusos. Campinas, SP: Editora Territorial, 2003

SOUCHAUD, S. e CARMO, R. L. Migração e mobilidade no Mercosul: a fronteira do Brasil com Bolívia e Paraguai. In: XV Encontro Nacional de Estudos Populacionais, ABEP, realizado em Caxambu/MG, de 18 a 22 de setembro de 2006.

SPRANDEL, M. A. Breve genealogia sobre os estudos de fronteiras \& limites no Brasil. IN: OLIVEIRA, R.C. e BAINES, S.G. (orgs.). Nacionalidades e etnicidade em fronteiras. Brasília: Editora da Universidade de Brasília, 2005.

STEIMAN, R. \& MACHADO, L.O. Limites e fronteiras internacionais: uma discussão histórico-geográfica. Rio de Janeiro: Igeo/Degeo/Grupo Retis, 2002. Disponível em www.igeo.ufrj.br/fronteiras/pesquisa/fronteira/p02avulsos04.htm Acessado em $\underline{08 / 10 / 2006 .}$

TASSI, N.; MEDEIROS, C.; RODRÍGUEZ-CARMONA, A.; FERRUFINO, G. Hacer plata sin plata: El desborde de los comerciantes populares en Bolívia. La Paz: Fundación PIEB, 2013. 
TRAVASSOS, M. Projeção Continental do Brasil. Brasiliana/Biblioteca Pedagógica Brasileira: Companhia Editora Nacional, série 5ª vol. 50, $4^{\text {a }}$ edição, 1947.

VAIOU, D. Hogar y lugar de trabajo: la experiência de las mujeres en el desarrollo urbano de Atenas. Documents D’Analisis Geogràfica 19-20, 1992, pp. 123-140

VALLAUX, C. El suelo y el Estado. Madrid: Editora Daniel Jorro, 1914.

VICENTE, A. As mulheres nos Mundos de Hoje. IN: HOLANDA, H. B.; CAPELATO, M. H. R. Relações de Gênero e Diversidades Culturais nas Américas. São Paulo: EDUSP, 1999.

VILARINO, R.C. Imperialismo e subimperialismo na América do Sul: os casos Malvinas e Roboré. Revista Lutas sociais, São Paulo, n.24, p. 140-151, 1º sem. 2010.

XAVIER, L. O. Fronteira Oeste Brasileira: entre o contraste e a integração. Universidade de Brasília. Brasília, 2006. Tese de doutorado. 
Entrevistas

C.F.. Entrevista I [set. 2014]. Entrevistadora: Dirce Sizuko Soken. Puerto Quijarro, Centro Comercial 12 de Octubre, 2014. 1 arquivo mp3 (13:00).

ILLIKA. Entrevista II [set. 2014]. Entrevistadora: Dirce Sizuko Soken. Puerto Quijarro, Centro Comercial 12 de Octubre, 2014. 1 arquivo mp3 (52:41)

ATIPAJ. Entrevista III [set. 2014]. Entrevistadora: Dirce Sizuko Soken. Puerto Quijarro, Centro Comercial 12 de Octubre, 2014. 1 arquivo mp3 (37:12)

KALLPA. Entrevista IV [set. 2014]. Entrevistadora: Dirce Sizuko Soken. Puerto Quijarro, Centro Comercial 12 de Octubre, 2014. 1 arquivo mp3 (26:42)

WAYRA. Entrevista V [set. 2014]. Entrevistadora: Dirce Sizuko Soken. Puerto Quijarro, Centro Comercial 12 de Octubre, 2014. 1 arquivo mp3 (15:25)

KUSISA. Entrevista VI [set. 2014]. Entrevistadora: Dirce Sizuko Soken. Puerto Quijarro, Centro Comercial 12 de Octubre, 2014. 1 arquivo mp3 (14:33)

WAYNA porteña. Entrevista VII [set. 2014]. Entrevistadora: Dirce Sizuko Soken. Puerto Quijarro, Calle 21 de Septiembre, 2014 (27:59)

WAYNA cruceña. Entrevista VIII [set. 2014]. Entrevistadora: Dirce Sizuko Soken. Puerto Quijarro, Calle 21 de Septiembre, 2014 (16:45)

WAYNA cochabambina. Entrevista XI [set. 2014]. Entrevistadora: Dirce Sizuko Soken. Puerto Quijarro, Calle 21 de Septiembre, 2014 (12:02)

SILLUKA. Entrevista X [set. 2014]. Entrevistadora: Dirce Sizuko Soken. Puerto Quijarro, Calle German Busch, 2014 (11:58)

SARIRI. Entrevista XI [set. 2014]. Entrevistadora: Dirce Sizuko Soken. Puerto Quijarro, Puerto Aguirre, 2014 (16:40)

KUCHIKUCHI. Entrevista XII [set. 2014]. Entrevistadora: Dirce Sizuko Soken. Corumbá (25:02) 
UTUYA. Entrevista XIII [set. 2014]. Entrevistadora: Dirce Sizuko Soken. Corumbá $(29: 50)$

SIPAKU. Entrevista XIV [set. 2014]. Entrevistadora: Dirce Sizuko Soken. Corumbá $(46: 50)$

JARAWI. Entrevista XV [set. 2014]. Entrevistadora: Dirce Sizuko Soken. Puerto Quijarro, Puerto Aguirre, 2014. 1 arquivo mp3 (22:20)

ANTAWARA. Entrevista XVI [set. 2014]. Entrevistadora: Dirce Sizuko Soken. Puerto Quijarro, Puerto Aguirre, 2014. 1 arquivo mp3 (20:07)

AMANKAYA. Entrevista XVII [set. 2014]. Entrevistadora: Dirce Sizuko Soken. Puerto Quijarro, Puerto Aguirre, 2014. 1 arquivo mp3 (46:05)

N.M. Entrevista XVIII [set. 2014]. Entrevistadora: Dirce Sizuko Soken. Puerto Quijarro, Puerto Aguirre, 2014. 1 arquivo mp3 (31:42)

MAYTA. Entrevista XIX [set. 2014]. Entrevistadora: Dirce Sizuko Soken. Puerto Quijarro, Puerto Aguirre, 2014. 1 arquivo mp3 (15:55)

YUPANKI. Entrevista XX [set. 2014]. Entrevistadora: Dirce Sizuko Soken. Puerto Quijarro, 2014. 1 arquivo mp3 (21:57)

SULATA. Entrevista XXI [set. 2014]. Entrevistadora: Dirce Sizuko Soken. Puerto Quijarro, Puerto Aguirre, 2014. 1 arquivo mp3 (16:47)

NAIRA. Entrevista XXII [set. 2014]. Entrevistadora: Dirce Sizuko Soken. Puerto Quijarro, Puerto Aguirre, 2014. 1 arquivo mp3 (21:42)

SAPAKI. Entrevista XXIII [set. 2014]. Entrevistadora: Dirce Sizuko Soken. Puerto Quijarro, Puerto Aguirre, 2014. 1 arquivo mp3 (29:32)

M.V.. Entrevista XXIV [set. 2014]. Entrevistadora: Dirce Sizuko Soken. Puerto Quijarro, Puerto Aguirre, 2014. 1 arquivo mp3 (60 min.).

D.G. Entrevista XXV [set. 2014]. Entrevistadora: Dirce Sizuko Soken. Puerto Quijarro, Centro Comercial 12 de Octubre, 2014. 1 arquivo mp3 (16:42) 
E.R. Entrevista XXVI [set. 2014]. Entrevistadora: Dirce Sizuko Soken. Corumbá, 2014. 1 arquivo mp3 (22:20)

J.T. Entrevista XXVII [set. 2014]. Entrevistadora: Dirce Sizuko Soken. Corumbá, 2014. 1 arquivo mp3 (45:40)

E.B. Entrevista XXVIII [set. 2014]. Entrevistadora: Dirce Sizuko Soken. Corumbá, 2014. 1 arquivo mp3 (61:00)

P.G.P.S. Entrevista XXIX [set. 2014]. Entrevistadora: Dirce Sizuko Soken. Corumbá, 2014. 1 arquivo mp3 (37:01)

I.F. Entrevista XXX [set. 2014]. Entrevistadora: Dirce Sizuko Soken. Corumbá, 2014. 1 arquivo mp3 (60:00)

M.A.Z. Entrevista XXXI [set. 2014]. Entrevistadora: Dirce Sizuko Soken. Corumbá, 2014. 1 arquivo mp3 (26:35)

O.L. Entrevista XXXII [ago. 2015]. Entrevistadora: Dirce Sizuko Soken. Campo Grande, 2015. 1 arquivo mp3 (02:08:22)

Z.M. Entrevista XXXIII [ago.2015]. Entrevistadora: Dirce Sizuko Soken. Campo Grande, 2015. 1 arquivo mp3 (56:45)

F.F. Entrevista XXXIV [ago. 2015]. Entrevistadora: Dirce Sizuko Soken. Corumbá, 2015. 1 arquivo mp3 (26:30)

J.S.S. Entrevista XXXV [ago. 2015]. Entrevistadora: Dirce Sizuko Soken. Corumbá, 2015. 1 arquivo mp3 (01:01:12) 


\section{APÊNDICE A - Questionários de campo}

\section{Modelo 1}

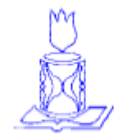

FFLCH

\author{
UNIVERSIDADE DE SÃO PAULO \\ Faculdade de Filosofia, Letras e Ciências Humanas - FFLCH \\ Programa de Pós-Graduação em Geografia Humana \\ Laboratório de Geografia Política e Planejamento Territorial e Ambiental - Laboplan \\ Laboratório de Geografia Política e Planejamento Territorial e Ambiental - Laboplan
Projeto de pesquisa: "Brasil e Bolivia: o trabalho feminino na produção do espaço de fronteira"
}

QUESTIONÁRIO 1: Corumbá/Puerto Quijarro/Puerto Suarez

(Uso do Tempo)

Data:

Ramo de atividade:

Local:

Entrevistada:

1) Quanto tempo você usa para realizar as suas atividades domésticas? Assinale um $(X)$ a única alternativa:

a) Preparar alimento por dia (horas)

( ) menos de 1 hora

( ) de 1 a 2 horas

( ) de 3 a 4 horas

( ) mais de 5 horas

( ) nenhuma das alternativas

b) Limpeza e cuidados com a casa por semana

( ) Uma vez na semana

( ) de 1 a 2 vezes na semana

( ) de 3 a 4 vezes na semana

c) Lavar e passar roupas por semana

( ) Uma vez na semana

) todos os dias

( ) de 1 a 2 vezes na semana

( ) de 3 a 4 vezes na semana

d) Cuidados com filho/familiares/amigos por dia (horas)
( ) menos de 1 hora
( ) de 1 a 3 horas
( ) de 4 a 6 horas
( ) de 7 a 10 horas
( ) mais de 10 horas
( ) nenhuma das alternativas

e) Outras atividades domésticas diárias (horas):

( ) menos de 1 hora

( ) de 1 a 2 horas

( ) todos os dias

( ) nenhuma das alternativas

( ) de 3 a 5 horas

( ) de 5 a 7 horas

( ) mais de 8 horas

( ) nenhuma das alternativas

\section{2) Realiza as atividades domésticas com ajuda de:}

a) ( ) familiares b) ( ) vizinhas, amigas c) ( ) outros d) ( ) nenhuma das alternativas 


\section{Modelo 2:}

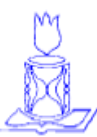

FFLCH

UNIVERSIDADE DE SÃO PAULO

Faculdade de Filosofia, Letras e Ciências Humanas - FFLCH

Programa de Pós-Graduação em Geografia Human

Laboratório de Geografia Política e Planejamento Territorial e Ambiental - Labopla

Projeto de pesquisa: "Brasil e Bolívia: o trabalho feminino na produção do espaço de fronteira"

QUESTIONÁRIO 2: Corumbá/Puerto Quijarro/Puerto Suarez

(Deslocamento das pessoas)

Data:

Ramo de atividade:

Local:

Entrevistada:

1) Com que frequência você compra alimentos? Assinale com $(\mathrm{X})$ as opções abaixo:

\begin{tabular}{|c|c|c|c|c|c|c|c|}
\hline & \multicolumn{3}{|c|}{ Dias } & \multicolumn{2}{|c|}{ Mês } & \multicolumn{2}{|l|}{ Ano } \\
\hline Cidades de compras & $\begin{array}{l}\text { Todos os } \\
\text { dias da } \\
\text { semana }\end{array}$ & $\begin{array}{l}\text { Entre } 3 \text { a } 5 \\
\text { dias da } \\
\text { semana }\end{array}$ & $\begin{array}{l}\text { Pelo menos } \\
1 \text { vez na } \\
\text { semana }\end{array}$ & $\begin{array}{l}\text { Entre } 2 \text { a } 3 \\
\text { vezes no } \\
\text { mês }\end{array}$ & $\begin{array}{l}\text { Pelo menos } \\
1 \text { vez no } \\
\text { mês }\end{array}$ & $\begin{array}{l}\text { Pelo menos } 1 \\
\text { vez no ano }\end{array}$ & Nunca \\
\hline Puerto Quijarro & & & & & & & \\
\hline Puerto Suarez & & & & & - & & \\
\hline Corumbá & & & & 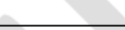 & $\nabla$ & & \\
\hline Outra & & & & & & & \\
\hline
\end{tabular}

2) Com que frequência você se desloca para outra cidade? Assinale com $(\mathrm{X})$ as opções abaixo:

\begin{tabular}{|c|c|c|c|c|c|c|c|}
\hline & & Dias & & & ês & Ano & \\
\hline Cidades de destino & $\begin{array}{l}\text { Todos os } \\
\text { dias da } \\
\text { semana }\end{array}$ & $\begin{array}{l}\text { Entre } 3 \text { a } 5 \\
\text { dias da } \\
\text { semana }\end{array}$ & $\begin{array}{l}\text { Pelo menos } \\
1 \text { vez na } \\
\text { semana }\end{array}$ & $\begin{array}{l}\text { Entre } 2 \text { a } 3 \\
\text { vezes no } \\
\text { mês }\end{array}$ & $\begin{array}{l}\text { Pelo menos } \\
1 \text { vez no mês }\end{array}$ & $\begin{array}{l}\text { Pelo menos } \\
1 \text { vez no ano }\end{array}$ & Nunca \\
\hline \multicolumn{8}{|c|}{ Puerto Quijarro } \\
\hline Puerto Suarez & & 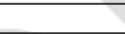 & & 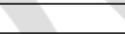 & 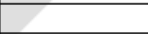 & & \\
\hline Corumbá & & 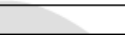 & & 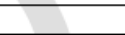 & & & \\
\hline Sta. Cruz da la Sierra & & 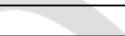 & 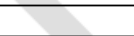 & & & & \\
\hline La Paz & & - & - & & & & \\
\hline Cochabamba & & & 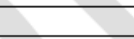 & 7 & & & \\
\hline Campo Grande & & & 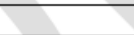 & 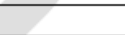 & & & \\
\hline São Paulo (capital) & & & & 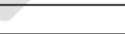 & & & \\
\hline Outra & & 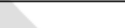 & & & & & \\
\hline
\end{tabular}

3) De acordo com os motivos abaixo, com que frequência você se desloca para outra cidade? Assinale com $(\mathrm{X})$ as opções abaixo:

\begin{tabular}{|c|c|c|c|c|c|c|c|}
\hline & & Dias & & \multicolumn{2}{|c|}{ Mês } & \multicolumn{2}{|l|}{ Ano } \\
\hline Motivos & $\begin{array}{l}\text { Todos os } \\
\text { dias da } \\
\text { semana }\end{array}$ & $\begin{array}{l}\text { Entre } 3 \text { a } 5 \\
\text { dias da } \\
\text { semana }\end{array}$ & $\begin{array}{l}\text { Pelo menos } \\
1 \text { vez na } \\
\text { semana }\end{array}$ & $\begin{array}{l}\text { Entre } 2 \text { a } 3 \\
\text { vezes no } \\
\text { mês }\end{array}$ & $\begin{array}{l}\text { Pelo menos } \\
1 \text { vez no mês }\end{array}$ & $\begin{array}{l}\text { Pelo menos } \\
1 \text { vez no ano }\end{array}$ & Nunca \\
\hline Trabalho & & & & & & & \\
\hline Residência & $\nabla=$ & & & & & & \\
\hline Compras & 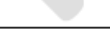 & & & & & & \\
\hline Saúde & & & & & & & \\
\hline Escola/Faculdade & & & & & & & \\
\hline Visita familiar & & & & & & & \\
\hline Outro & & & & & & & \\
\hline
\end{tabular}




\section{Modelo 3:}

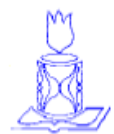

UNIVERSIDADE DE SÃO PAULO

Faculdade de Filosofia, Letras e Ciências Humanas - FFLCH

Programa de Pós-Graduação em Geografia Humana

Laboratório de Geografia Politica e Planejamento Territorial e Ambiental - Laboplan

Laboratório de Geografia Política e Planejamento Territorial e Ambiental - Laboplan
Projeto de pesquisa: "Brasil e Bolíia: o trabalho feminino na produção do espaço de fronteira"

FFLCH

QUESTIONÁRIO 3: Corumbá/Puerto Quijarro/Puerto Suarez

(Uso da renda)

Data:

Ramo de atividade:

Local:

Entrevistada:

O quanto da sua renda pessoal (remuneração/salário) você gasta com: Assinale com (X) a única alternativa:

1) Alimentação (mensal):
a) ( ) muito
c) ( ) raramente
b) ( ) pouco
d) ( ) nunca

2) Moradia (aluguel/prestação do imóvel/água/luz) (mensal)
a) ( ) muito
c) ( ) raramente
b) ( ) pouco
d) ( ) nunca

3) Comunicação (telefonia fixa/celular/internet) (mensal)
a. ( ) muito
c. ( ) raramente
b. ( ) pouco
d. ( ) nunca

4) Transporte (carro/ônibus/van/moto) (mensal)
a. ( ) muito
c. ( ) raramente
b. ( ) pouco
d. ( ) nunca

5) Educação (escola/cursos profissionalizantes/graduação/pós-graduação) (mensal)
a. ( ) muito
c. ( ) raramente
b. ( ) pouco
d. ( ) nunca

6) Saúde (remédios/consultas/plano de saúde) (mensal)
a. ( ) muito
c. ( ) raramente
b. ( ) pouco
d. ( ) nunca

7) Investimentos/Poupança (mensal)
a. ( ) muito
c. ( ) raramente
b. ( ) pouco
d. ( ) nunca

8) Diversão e outros (mensal)
a. ( ) muito
c. ( ) raramente
b. ( ) pouco
d. ( ) nunca 
Modelo 4: parte 1
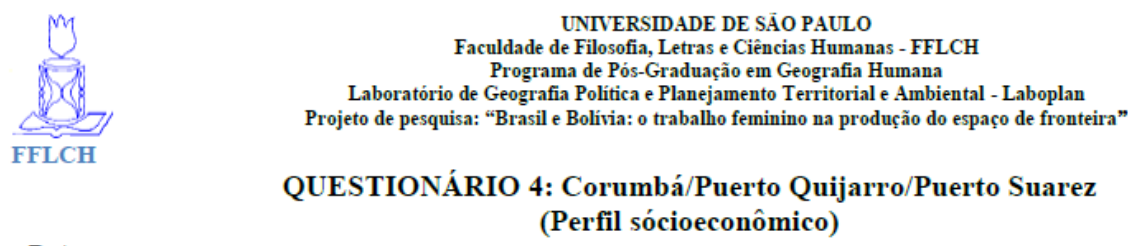

Data:

Ramo de atividade:

Local:

Entrevistada:

1) Qual cidade você nasceu?

2) Qual é a sua idade?

3) Qual a nacionalidade da sua mãe?

4) Onde mora atualmente?(MÚLTIPLA)

a) ( ) Bolívia (especificar a cidade)

b) ( ) Corumbá/Brasil

c) ( ) Outro (especificar a cidade):

5) Tempo de residência:

6) Já residiu em outra cidade? a) ( ) Sim b) ( )Não (Se P6 for negativa, ir para P9 )

7) Qual outra cidade você já morou?

8) Qual o principal motivo de morar em outra cidade? (ESPONTÂNEA E ÚNICA)
a) ( ) Emprego
d) ( ) Escola/Universidade
b) ( ) Negócios
e) ( ) Familiar
c) ( ) Assistência à Saúde
f) ( ) outros

9) Qual é a sua escolaridade?(usar grifo nas alternativas b,c e d)

a) ( ) Analfabeta

c) ( ) Ensino Médio (completo/incompleto)

b) ( ) Ensino Fundamental (completo/incompleto)

d) ( ) Ensino Superior (completo/incompleto)

10) Qual é a sua renda (PESSOAL) mensal?
a) ( ) menos $1 \mathrm{SM}$
b) ( ) de 1 a $2 \mathrm{SM}$
d) ( ) de 5 a $10 \mathrm{SM}$
c) () de 2 a $5 \mathrm{SM}$
e) ( ) Acima de $10 \mathrm{SM}$
f) ( ) Sem rendimento

11) Qual é a sua renda (FAMILIAR) mensal?
a) ( ) menos de $1 \mathrm{SM}$
d) ( ) de 5 a $10 \mathrm{SM}$
b) () de 1 a $2 \mathrm{SM}$
c) () de 2 a $5 \mathrm{SM}$
e) ( ) Acima de $10 \mathrm{SM}$
f) ( ) Sem rendimento

12) Estado civil:
a) ( ) solteira
b) ( ) casada
c) ( ) divorciada

d) ( ) separada

e) ( ) outra (especificar)

13) Tem filhos? a) ( ) Sim b) ( )Não (Se P13 negativa ir para P15)

14) Qual é a idade dos filhos?

15) Quantas pessoas moram com você?

16) Há quanto tempo está nesta atividade? 
Modelo 4: parte 2
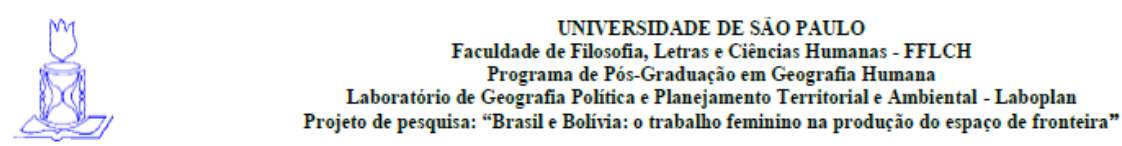

17) Hoje, qual é a sua jornada de trabalho diária?

18) Anterior a esta atividade, já exerceu outra atividade remunerada? a) ( ) Sim b) ( )Não (Se P18 for negativa, ir para $\mathbf{P 2 0}$ )

19) Qual(is) atividade(s) remunerada já exerceu?
a) ( ) comércio varejista/atacadista
b) ( ) serviços:
d) ( ) agricultura e pecuária:
c) ( ) indústria:
e) ( ) outra (especificar)

20) Atualmente realiza outra(s) atividade(s) remunerada? a) ( ) Sim b) ( )Não (Se P20 for negativa, ir para P22)

21) Qual(is) outra(s) atividade(s) remunerada realiza?

22) É funcionária/empregada do estabelecimento? a) ( ) Sim b) ( )Não (Se P22 for negativa ir para P25)

23) Possui relação familiar com o(a) proprietário(a) do estabelecimento? a) ( ) Sim b) ( )Não (Se P23 for negativa ir para $\mathrm{P25}$ )

24) Qual é a relação familiar?

25) Têm familiares que moram do outro lado da fronteira? a) ( ) Sim b) ( ) Não

26) Têm familiares que trabalham nas cidades brasileiras e/ou bolivianas?
a) ( ) Sim. Qual (is)?
b) ( ) Não

27) Qual é sua função nesta atividade: (MÚLTIPLA)
a) ( ) proprietária
d) ( ) caixa
b) ( ) gerente geral
e) ( ) outros (especificar):
c) ( ) vendedora/ atendente

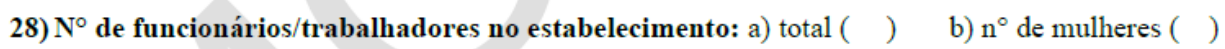

29) Por que você trabalha nesta atividade? (ESPONTÂNEA E MÚLTIPLA)
a) ( ) a remuneração/rendimento é melhor que
c) ( ) tradição familiar outras atividades

d) ( ) outro (especificar)

b) ( ) primeiro emprego/negócio

30) Qual é a moeda que utiliza para fazer compras/pagamentos/recebimentos?(MÚLTIPLA)
a) ( ) Real
d) ( ) outro (especificar)
b) ( ) Dólar
c) ( ) Peso boliviano 


\section{APÊNDICE B - Questões de entrevistas}

1) Você gosta de trabalhar nesta cidade? Por que?

2) O que você conquistou com seu trabalho?

3) É fácil ou difícil trabalhar na fronteira entre Bolívia e Brasil? Por que?

4) O que você acha da infraestrutura/instalações do local de trabalho, está adequado as suas atividades/função?

5) Onde você acha que é melhor para fazer compras, quais locais? Por que?

6) Onde você acha que é melhor para morar, quais locais? Por que?

7) Com quantos anos começou a trabalhar? Qual era o trabalho/atividade que realizava?

8) Seu trabalho/atividade atual é realizado por quantas horas diárias?

9) Para realizar seu trabalho você precisou/precisa de instrução/qualificação/treinamento?

10) No seu trabalho/atividade de quem você depende para exercer sua função? É subordinado a quantas pessoas?

11) Como você é remunerada?

i) recebe remuneração/salário direta ou indiretamente (marido/filhos/outro)?

ii) recebe a remuneração/salário de forma integral/parcial?

iii) recebe a remuneração/salário regular/irregularmente?

12) Você acha que ganha mais ou menos que os homens? Por que?

13) Você acha que tem mais ou menos oportunidades de trabalho do que os homens? Por que?

14) Como o seu trabalho contribui para sua família? Quais sacrifícios são realizados?

15) Que benefícios o seu trabalho/atividade trouxe para sua vida pessoal e/ou familiar?

16) Seu trabalho/atividade é considerado(a) insalúbre/perigoso/arriscado?

17) Sobre Corumbá o que você considera que seja bom e/ou ruim na cidade? E como você acha que essa cidade contribui para a execução do seu trabalho/atividade?

18) Sobre as cidades Puerto Quijarro e Puerto Suarez o que você considera que seja bom e/ou ruim nessas cidades? E como você acha que essas cidades contribuem para a execução do seu trabalho/atividade?

19) Como você considera as relações de negócios/trabalho nas cidades fronteiriças? São confiáveis? 